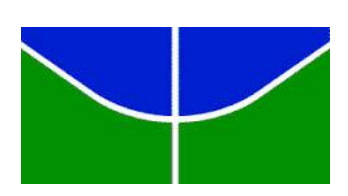

UNIVERSIDADE DE BRASILIA

INSTITUTO DE CIÊNCIAS HUMANAS

PROGRAMA DE PÓS-GRADUAÇÃO EM GEOGRAFIA

MESTRADO

ÁREA DE CONCENTRAÇÃO:

PRODUÇÃO DO ESPAÇO URBANO, RURAL E REGIONAL

IARA CRISTINA DA SILVA AlVES

DISSERTAÇÃO DE MESTRADO

POLÍTICAS PÚBLICAS, TERRITORIALIDADE E LIBERDADE DOS REMANESCENTES DE QUILOMBO KALUNGA

Orientador: Professor Dr. Fernando Luiz AraúJo Sobrinho BRASÍLIA, MAIO DE 2015 
Ficha catalográfica elaborada automaticamente, com os dados fornecidos pelo(a) autor(a)

ALVES, IARA

POĹTTICAS PUBLICAS, TRRRITORIALIDADE E LIBERDADE DOS REMANESCENTES DE QUILOMBO KALUNGA / IARA ALVES; orientador PERNANDO LUIZ ARAUJUO SOBRTNHO. Branilia, 2015.

$262 \mathrm{p}$.

Disaertação (Meatrado - Meatrado en Geografia) -. Univeraidade de Branilia, 2015.

1. politican públicas. 2. territ6rio Kalunga. 3. quilombol ARAGJU SOBRINHO, FERNANDO LUIZ, orient. II. Título. 
UNIVERSIDADE DE BRASILIA

DEPARTAMENTO DE GEOGRAFIA

\section{POLÍTICAS PÚBLICAS, TERRITORIALIDADE E LIBERDADE \\ DOS REMANESCENTES DE QUILOMBO KALUNGA}

\section{Iara Cristina da Silva Alves}

Dissertação de Mestrado submetida ao Departamento de Geografia da Universidade de Brasília, como parte dos requisitos necessários para obtenção do Grau de Mestre em Geografia, área de concentração Produção do Espaço Urbano, Rural e Regional.

Aprovado por:

Prof. Dr. Fernando Luiz Araújo Sobrinho (Orientador)

Universidade de Brasília

Prof. Dr. Neio Lúcio de Oliveira Campos

Universidade de Brasília

Prof. Dra. Bernadete Aparecida Caprioglio de Castro

Universidade Estadual Paulista, Rio Claro

Dr. João Mendes da Rocha Neto

Ministério do Planejamento, Orçamento e Gestão

Brasília, 17 de junho de 2015 
Dedico este trabalho ao João Pedro, hoje uma criança de 6 anos, para que ele se torne um homem que acredita na possibilidade de um país mais justo. 


\section{Agradecimentos,}

Agradeço, antes de tudo, àqueles que tem me orientado em todo o meu caminho e possibilitam meus aprendizados, minha mãe, Maria Aparecida da Silva Cunha, e meu pai, Geraldo Alves da Cunha. Pais amados que me ensinaram a acreditar no melhor que cada um pode trazer dentro do seu coração. A minha mãe agradeço também a parceria constante e disponibilidade para a maternidade e cuidados com meu filho.

Sou grata ao meu marido, companheiro de toda a minha vida, João Oliveira Gualberto Júnior, pelo apoio incondicional, compreendendo as minhas angústias, minhas ausências nos fins de semanas e nas noites em claro, e, principalmente, nas semanas da pesquisa em campo.

Agradeço a minha amiga Patrícia Mollo, que me apresentou Milton Santos, que me fez ver na Geografia a concretização de um sonho de pesquisa que eu guardava em meu coração há alguns anos. Sentirei falta dos estudos em conjunto e das discussões de leituras.

Agradeço ao meu amigo Antônio Claret, que tanto me falou de Amartya Sen, que me incentivou na leitura do desenvolvimento como liberdade e sobre qualidade de vida e que me inspirou nas reflexões e discussões sobre as políticas sociais.

Meus sinceros agradecimentos aos Kalunga que abriram as portas de suas casas e seus corações para as longas conversas que tivemos: Seu Cirilo, Dona Getúlia e Rita, do Engenho II; Seu Mochila, Dona Iva, Dona Aimiram e Seu Manuel, do Vão do Moleque; Seu Zezinho, Dona Titinha, Dona Eva, Seu Albertino, Dona Persília, Professora Irene, do Vão de Almas; e, Vilmar Sousa, Presidente da Associação Quilombo Kalunga.

Agradeço a Marta Damasco, Médica do Programa Mais Médicos, que tirou muito de seu tempo para conversar e ainda me hospedou em sua casa.

Agradeço ao Beto Baiano por não só me guiar, mas me orientar sobre as pessoas com quem eu deveria conversar, por se disponibilizar a me acompanhar de carro, de canoa, a pé, mesmo em baixo de chuva, e conversar sobre todos os assuntos desde políticas públicas a festas Kalunga.

Agradeço aos meus queridos amigos que contribuíram, cada um a sua maneira, para minhas reflexões: Janine, Eric, Cristiane e Concha. Ao Eric agradeço também a cuidadosa revisão do texto. 
Agradeço apoio de todos os colegas do MDS, em especial, Sérgio Magalhães e Leonardo Prudente, que nunca reclamaram ou fizeram cara feia e assumiram minhas funções com carinho e dedicação quando tive que estar ausente. Ao meu chefe, Marcelo Cardona, agradeço a compreensão e suporte essenciais para o percurso de toda a trajetória.

Sou grata ao meu orientador, Professor Fernando Sobrinho, que em todo o tempo confiou e acreditou no meu trabalho. A conclusão dessa dissertação somente foi possível pelo seu acolhimento inicial da proposta e por sua atenciosa orientação.

Finalmente, agradeço ao meu filho, João Pedro, por me oferecer tanto amor, carinho e inspiração, sendo sempre o meu maior conforto e razão para trabalhar para que o mundo seja melhor e mais justo com todos os homens, mulheres e crianças. 


\section{Resumo}

A pesquisa aborda a situação de vulnerabilidade social historicamente e espacialmente produzida nos territórios das comunidades remanescentes de quilombos no Brasil, pretendendo verificar os possíveis efeitos das políticas públicas articuladas para os quilombolas, no seu espaço e desenvolvimento humano. Para efeitos de delimitação de pesquisa, foi considerado o recorte territorial da Comunidade Kalunga, localizada no nordeste goiano. Após análise de dados socioeconômicos do território, da ação de políticas públicas no espaço e a partir da pesquisa de base etnográfica no território Kalunga, foi possível, a partir da teoria do espaço geográfico de Milton Santos e do desenvolvimento como liberdade de Amartya Sen, checar a hipótese de que a inserção de políticas públicas que visam reduzir a pobreza bem como aumentar o acesso a serviços públicos e as oportunidades de inclusão socioeconômica permitem aumentar a capacidade e a liberdade dos quilombolas.

Palavras-chave: Políticas Públicas, Território Kalunga, Quilombolas, Desenvolvimento como Liberdade. 


\begin{abstract}
This study draws upon the situation of social vulnerability historically and spatially produced in remaining communities of quilombos, a Brazilian hinterland settlement founded by people of African origin. The purpose is to identify the possible effects of public policies on the space and human development of the quilombolas. The research focuses on the Kalunga community, which is located in the northeast of the state of Goiás, Brazil. It has provided an analysis of socioeconomic data of the municipalities in which the Kalunga territory is inserted and of the action of public policies on its space. Added to that, the ethnographic research in the Kalunga territory allowed us to reflect on Milton Santos' Geographic Space Theory and on Amartya Sen's concept of development as freedom. It was possible to conclude that the insertion of public policies that aim at reducing poverty and raising access to public services and to opportunities of socioeconomic inclusion allows broadening quilombolas' capacities and freedom.
\end{abstract}

Key Words: Public Policies, Kalunga Territory, Quilombolas, Development as Freedom. 


\section{LISTA DE FIGURAS}

Figura 1- Localização da Comunidade Kalunga em Goiás. Fonte: Lara, Ferreira. UFG.........19

Figura 2: Concentração dos territórios quilombolas titulados. Fonte: Sistema de

Monitoramento, SEPPIR, BRASIL, 2015

Figura 3- Localidades quilombolas e fazendas no sítio histórico e cultural da comunidade

Kalunga. Autoria: Rafael. S.A dos Anjos. Centro de Cartografia Aplicada e Informação

Geográfica. UNB. S.d. 50

Figura 4 - Formação vegetal de cerrado e chapadões. Fonte: A autora, junho 2013 .................54

Figura 5- Casa de Farinha no povoado da Ema. Fonte: A autora, junho 2013 ............................57

Figura 6- Escola estadual na Comunidade Engenho II. Fonte: A autora, fevereiro, 2015 ........57

Figura 7- Povoado do Engenho II. Fonte: A autora, fevereiro, 2015. 58

Figura 8- Centro de Atendimento ao Turista no Engenho II. Fonte: A autora, fevereiro, 2015.

Figura 9- Vão de Almas: travessia de canoa no Rio das Almas. Fonte: A autora, março, 2015

Figura 10- Imensidão do verde do Vão do Moleque. Fonte: A autora, fevereiro, 2015..........59

Figura 11- Vão de Almas: Casa de adobe e palha. Fonte: A autora, março, 2015. 60

Figura 12- Mulheres Kalunga voltando do rio com as louças lavadas e a água para consumo na cabeça. Fonte: A autora, fevereiro, 2015

Figura 13- Capela do Vão do Moleque, fechada durante o ano inteiro. Abre somente na festa, quando o padre celebra a missa. Fonte: A autora, fevereiro, 2015. 63

Figura 14- Local do festejo no Vão do Moleque. Aqui as barracas que os moradores acampam por dias enquanto duram as festas. Fonte: A autora, fevereiro, 2015. 63

Figura 15- Engenho II: Festa de Santo Antônio. Fonte: http://www.novaorigem.com.br, acesso em: 22 fev. 2014

Figura 16- Vulnerabilidade da população brasileira por Estado. Fonte: IBGE, 2012.

Figura 17- Distribuição da população quilombola por vulnerabilidade. Fonte: BRASIL, 2012

Figura 18- Vulnerabilidade e renda domiciliar per capita quilombola. Fonte: BRASIL, 2012 
Figura 19- Situação da Segurança Alimentar e Nutricional da Comunidade Kalunga. Fonte: Brasil, 2012.

Figura 20- Rendimento médio per capita dos domicílios quilombolas titulados- médias estaduais- 2011. Fonte: BRASIL, 2012

Figura 21: Seu Cirilo, Comunidade Engenho II, fev. 2015. Fonte: a autora. 126

Figura 22: Seu Mochila, Comunidade do Vão do Moleque, fev. 2015. Fonte: a autora...129 Figura 23: Reunião do Comitê Gestor das Comunidades Remanescentes de quilombos do Estado de Goiás em 2008. Fonte: a autora. 130

Figura 24: Estrada para o Vão do Moleque, fev. 2015. Fonte: a autora 136

Figura 25: Travessia de córregos com pedras da estrada para o Vão do Moleque, fev.

2015. Fonte: a autora.

Figura 26: Dificuldades na estrada para o Vão do Moleque, fev. 2015. Fonte: a autora.137

Figura 27: Caminho para o Vão de Almas, mar. 2015. Fonte: a autora. 141

Figura 28: Travessia de Canoa no Vão de Almas para chegar à escola, fev. 2015. Fonte:

Beto Baiano 143

Figura 29: Dona Eva, do Vão de Almas, tecendo algodão, mar. 2015. Fonte: Beto Baiano.

Figura 30: Titinha, Vão de Almas, mar. 2015. Fonte: a autora.

Figura 31: Casa de Seu Zezinho e Dona Tininha, Vão de Almas, mar. 2015. Fonte: a autora.

Figura 32: Casa de Dona Eva, de adobe e telhado de palha, típica do Vão de Almas, mar.

2015. Fonte: a autora. 151

Figura 33: Casa de Alvenaria construída por Seu Albertino com sua aposentadoria, mar.

2015. Fonte: a autora. 152

Figura 34: Seu Albertino da Comunidade do Vão de Almas, mar. 2015. Fonte: a autora.

Figura 35: Casa de Rita, do Engenho II, construída pelo programa de moradias do

Governo Federal, mar. 2015. Fonte: a autora.

Figura 36: Casa de Dona Aimiram no Vão do Moleque, construída pelo programa de moradias do Governo Federal, fev. 2015. Fonte: a autora.. 155

Figura 37: Cisterna de captação de água pluvial no Vão do Moleque, fev. 2015. Fonte: a autora. 156

Figura 38: Rita, guia turística do Engenho II, fev. 2015. Fonte: a autora. 175 
Figura 39: Escola no Vão de Almas, mar. 2015. Fonte: Beto Baiano. 180

Figura 40: Sede da Associação Quilombo Kalunga em Cavalcante, mar. 2015. Fonte: a autora. 185

Figura 41: Dona Getúlia, do Engenho II, fev. 2015. Fonte: a autora. 188 


\section{LISTA DE GRÁFICOS}

Gráfico 1- Regularização da terra quilombola.

Gráfico 2- Distribuição da população brasileira por vulnerabilidade.

Gráfico 3- Razão de dependência de jovens e idosos.

Gráfico 4- Índice de Desenvolvimento Humano Municipal dos municípios onde o Território Kalunga está inserido.

Gráfico 5- Distribuição das formas de organização no trabalho das famílias quilombolas. ....80 


\section{LISTA DE ABREVIATURAS E SIGLAS}

ADCT- Ato das Disposições Constitucionais Transitórias

ASQ- Agenda Social Quilombola

AQK- Associação Quilombo Kalunga

BPC- Benefício de Prestação Continuada

BSM- Programa Brasil Sem Miséria

CNPCT- Comissão Nacional de Desenvolvimento Sustentável dos Povos e Comunidades

Tradicionais

CONAQ- Coordenação Nacional de Articulação das Comunidades Negras Rurais

Quilombolas

CRAS- Centro de Referência da Assistência Social

EBIA- Escala Brasileira de Medida Domiciliar de Insegurança Alimentar

FCP- Fundação Cultural Palmares

IBGE- Instituto Brasileiro de Geografia e Estatística

IDAGO- Instituto do Desenvolvimento Agrário de Goiás

IDHM- Índice de Desenvolvimento Humano Municipal

INCRA- Instituto Nacional de Colonização e Reforma Agrária

MDA- Ministério do Desenvolvimento Agrário

MDS- Ministério do Desenvolvimento Social e Combate à Fome

MNU- Movimento Negro Unificado

PAA- Programa de Aquisição de Alimentos

PBQ- Programa Brasil Quilombola

PNAD- Pesquisa Nacional Por Amostra de Domicílios

PNUD- Programa das Nações Unidas para o Desenvolvimento

PPA- Programa Plurianual 
RTID- Relatório Técnico de Identificação e Delimitação

SEPPIR- Secretaria Especial de Promoção da Igualdade Racial

SUAS- Sistema Único da Assistência Social

TCU- Tribunal de Contas da União

UFG- Universidade Federal de Goiás

UNB- Universidade de Brasília

UNESP- Universidade Estadual Paulista 


\section{SUMÁRIO}

$\begin{array}{ll}\text { RESUMO } & 7\end{array}$

$\begin{array}{lr}\text { ABSTRACT } & 8\end{array}$

LISTA DE FIGURAS 9

LISTA DE GRÁFICOS 12

LISTA DE ABREVIATURAS E SIGLAS

SUMÁRIO

$\begin{array}{ll}\text { INTRODUÇÃO } & 18\end{array}$

1.CAPÍTULO 1

CONSTRUÇÃO DA TERRITORIALIDADE E ESPACIALIDADE KALUNGA 37

1.1.A BUSCA PELA LIBERDADE 37

1.2.TERRITORIALIDADE 43

1.3.0 MODO DE VIVER KALUNGA

1.4.CARACTERIZAÇ̃̃O SOCIAL E ECONÔMICA DA COMUNIDADE KALUNGA 67

2.CAPÍTULO 2

POLÍTICAS PÚBLICAS E DESENVOLVIMENTO 86

2.1.DESENVOLVIMENTO COMO LIBERDADE E O PAPEL DO ESTADO 86

2.2.PROGRAMAS E POLÍTICAS PÚBLICAS TRANSVERSAIS VOLTADOS PARA QUILOMBOLAS 100

3.CAPÍTULO 3

VOZ E LIBERDADE KALUNGA 120

3.1.DEPOIS DISSO AÍ É SÓ A GENTE SE DESENVOLVENDO 126

3.2.NOSSA SAÚDE, NOSSA EDUCAÇÃO, NOSSO DESENVOLVIMENTO EM GERAL ESTÁ RELACIONADO À ESTRADA.

3.3. SE QUISER LUMIAR É COM ÓLEO MESMO, POR QUE NÃO TEM ENERGIA. O ÓLEO É DANADO PARA ATACAR AS VISTAS DA GENTE. MAS AQUI É ASSIM.

3.4.É BOM DEMAIS PODER TOMAR BANHO NO CHUVEIRO QUENTE, PODER IR NO BANHEIRO DENTRO DE CASA. NOSSA, É MUITO DIFERENTE!

3.5.OLHA A AGUA DO PARANÃ AGORA PROCÊ VER A AGUA QUE AS CRIANÇAS BEBE, SÓ TEM BARRO [...] A BARRIGA DELES TEM MAIS É VERME 
3.7.A FOME QUE TINHA ANTIGAMENTE, ESSA DEUS NUM DEIXA ENTRAR MAIS 167

3.8.É POUCO MAS TÁ BOM. O RUIM É NADA 170

3.9.SER ANALFABETO DÓI $\quad 175$

3.10.BOM FICAR É NO LUGAR ONDE A GENTE NASCEU E CRIOU E CONHECE 182

3.11.É O LUGAR MAIS ESQUECIDO É O NOSSO VÃO DE ALMAS. MUITA GENTE DE FORA VEM AQUI, PARTICIPA DE NÓS, USA O NOME DE NÓS, LEVA LÁ PRA FORA, E NUNCA QUE CHEGA NADA

4.CONSIDERAÇÕES FINAIS

EU GOSTO É DE FOTO VIVA 188

5.REFERÊNCIAS BIBLIOGRÁFICAS E ELETRÔNICAS 201

$\begin{array}{ll}\text { ANEXO } & 208\end{array}$ 


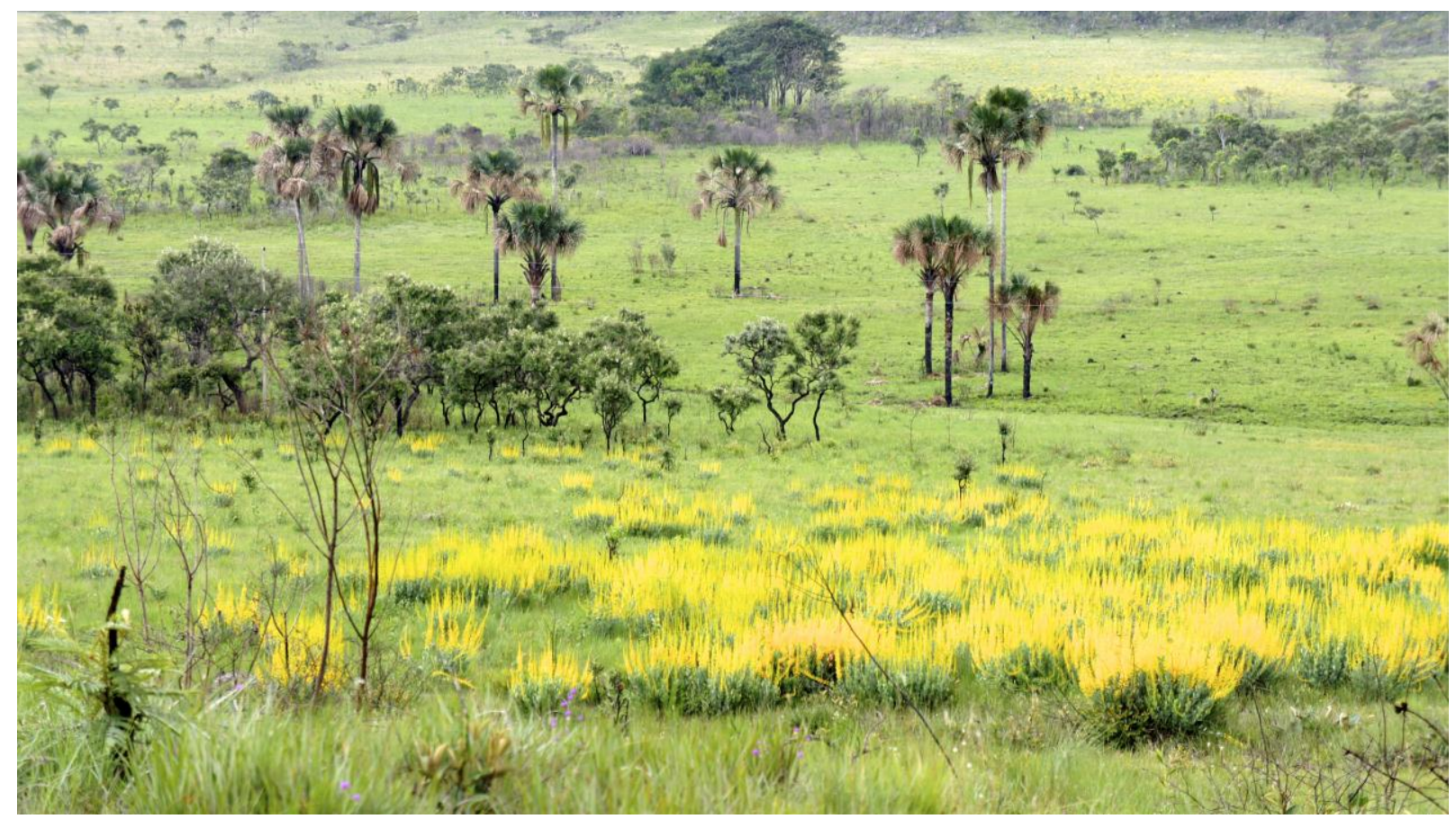

Território Kalunga

"Vivendo, se aprende: mas o que se aprende mais é a fazer outras maiores perguntas".

(Guimarães Rosa, Grande Sertão Veredas) 


\section{INTRODUÇÃO}

Os quilombos formados nos séculos XVIII e XIX no Brasil marcaram a luta dos escravos de origem africana pela liberdade, por uma vida digna ,com liberdade e com melhor qualidade. Porém, a luta dos povos de matriz africana e dos remanescentes de quilombo perdura até os dias atuais. Mais de cem anos após a abolição da escravidão, questiona-se o alcance da almejada mudança social.

Até que ponto os descendentes dos escravos que tanto guerrearam e morreram em defesa da liberdade hoje de fato usufruem da vida sem correntes e sem capitão do mato? O que o Estado brasileiro tem feito no sentido de reparar a histórica injustiça social ainda hoje percebida na configuração territorial segregada das comunidades remanescentes de quilombo?

A temática central desta pesquisa aborda a situação de vulnerabilidade social historicamente e espacialmente produzida nos territórios das comunidades remanescentes de quilombos no Brasil, pretendendo verificar os efeitos das políticas sociais articuladas para os quilombolas, no seu espaço e desenvolvimento humano.

Como remanescentes de quilombo entende-se os "grupos étnico-raciais, segundo critérios de auto-atribuição, com trajetória histórica própria, dotados de relações territoriais específicas, com presunção de ancestralidade negra relacionada com a resistência à opressão histórica sofrida", de acordo com o Decreto $\mathrm{n}^{\circ} 4887$ de 2003, que regulamenta o procedimento para identificação, reconhecimento, delimitação, demarcação e titulação das terras ocupadas por remanescentes das comunidades dos quilombos.

Para efeitos de delimitação de pesquisa, será considerado o recorte territorial da Comunidade Kalunga, que abrange os municípios de Monte Alegre, Teresina de Goiás e Cavalcante, localizados no nordeste de Goiás, microrregião da Chapada dos Veadeiros (Figura 1). Destacamos que, como o objeto principal deste estudo é o espaço quilombola, será dada ênfase à área rural desses municípios, sendo a área urbana tratada apenas para efeito de comparação. 


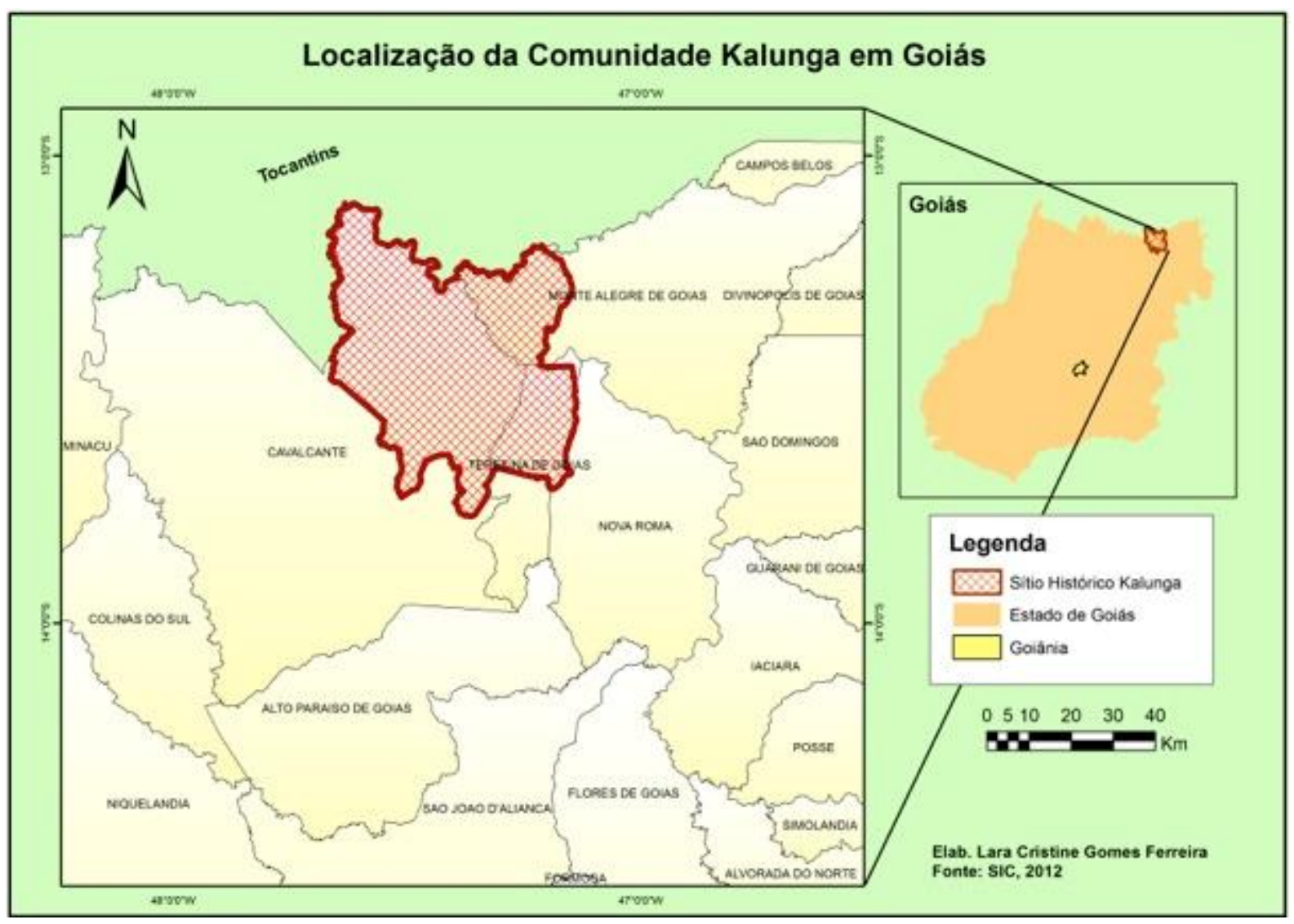

Figura 1- Localização da Comunidade Kalunga em Goiás. Fonte: Lara, Ferreira. UFG.

Ressalta-se ainda que o recorte temporal inicia-se em 2003, quando o Estado brasileiro finalmente assume como prioridade governamental a luta contra a pobreza e as desigualdades sociais. Em 2004, é realizada a primeira tentativa de política pública com recorte étnicoterritorial para os remanescentes de quilombo com o lançamento do Programa Brasil Quilombola-PBQ. Serão utilizados dados de análise referentes a 2010 - ano do Censo Demográfico, 2011 - ano da realização da pesquisa de campo da pesquisa realizada pelo Ministério do Desenvolvimento Social e Combate à Fome - MDS sobre a situação de segurança alimentar dos quilombolas, e 2013 - quando é possível ter dados mais recentes sobre a implementação e gestão do PBQ com o Relatório de Gestão da Secretaria Especial de Políticas de Promoção da Igualdade Racial-SEPPIR e sobre a situação de vulnerabilidade dos Kalunga segundo dados do Cadastro Único para Programas Sociais do Governo FederalCadastro Único.

As comunidades remanescentes de quilombo finalmente tiveram reconhecimento como categoria de acesso a direitos com a promulgação da Constituição Federal de 1988, nos seus artigos 215 e 216 e no Artigo 68 do Ato das Disposições Constitucionais Transitórias. A 
Carta Magna não só deu visibilidade à contribuição dos quilombolas para a formação do patrimônio cultural brasileiro mas principalmente reconheceu os direitos territoriais das comunidades quilombolas. No entanto, os avanços para efetivação do direito à terra pelos quilombolas têm sido retardados pelas inúmeras etapas burocráticas perpassando questões fundiárias no judiciário.

O primeiro passo para a garantia do direito à terra é ter a certificação de comunidade quilombola, sob responsabilidade da Fundação Cultural Palmares-FCP do Ministério da Cultura. Após a certificação, deve-se requerer o título da propriedade ao Instituto Nacional de Colonização e Reforma Agrária do Ministério do Desenvolvimento Agrário- INCRA/MDA.

Segundo dados da SEPPIR/PR (2013), 2.187 comunidades foram certificadas pela FCP até 2012, porém somente 207 tiveram suas terras tituladas, representando uma área de 995,1 mil hectares regulamentados no território nacional.

A comunidade Kalunga, segundo dados da Fundação Cultural Palmares, recebeu a certificação de comunidade quilombola em abril de 2005. Reconhecido como Sítio Histórico e Patrimônio Cultural Kalunga por meio das Leis Estadual $n^{\circ} 11.409$, de 21 de janeiro de 1991 e Complementar do Estado de Goiás nº 19, de 5 de janeiro de 1996. Seu território, 253,2 mil hectares de terras, já foi considerado apto à titulação pelo INCRA, faltando, no entanto, receber o documento de posse que garanta aos Kalunga os direitos plenos da propriedade da terra.

A cerca de 600 km de Goiânia e a 330 km de Brasília, o Sítio Histórico e Patrimônio Cultural Kalunga possui cinco grandes núcleos: Contenda, Kalunga, Vão de Almas, Vão do Moleque e Ribeirão dos Bois. Estes subdividem-se em dezenas de agrupamentos ou povoados, como: Contenda, Barra, Riachão, Sucuriú, Curral de Taboca, Saco Grande, Ema, Diadema, Engenho II, entre tantos outros.

Os Kalunga são descendentes dos mais de nove mil escravos negros levados pelos Bandeirantes a Goiás para a exploração do ouro e permaneceram isolados até meados dos anos 1980, sem contar com água encanada, energia elétrica ou qualquer outro serviço público de provisão essencial, como saúde e educação. 
Excluídos do mercado de produção e sem acesso a serviços públicos essenciais durante anos, os remanescentes de quilombo Kalunga desenvolveram uma relação harmônica com a natureza, preservaram os espaços naturais e desenvolveram técnicas próprias de subsistência com a extração dos recursos naturais do cerrado, preservando sua vegetação nativa e o meio ambiente, em uma relação simbiótica com a natureza.

No entanto, o território Kalunga, inserido na área dos pequenos municípios goianos de Monte Alegre, Teresina e Cavalcante, se encontra em situação de pobreza e vulnerabilidade. Esses municípios possuem altos índices de pobreza e desigualdade, estando entre os mais pobres do Estado de Goiás. Além do que, a situação de vulnerabilidade econômica e social de sua população rural é especialmente agravada pelo histórico descaso do poder público local em relação ao território.

O espaço Kalunga registra evolução desigual não só em relação à zona urbana dos munícipios de Monte Alegre, Teresina de Goiás e Cavalcante, mas também entre seus agrupamentos ou povoados, de acordo com a distância que se encontram da sede dos municípios ou com a capacidade desenvolvida de explorar seu território para alguma atividade produtiva.

As diferenças perpassam o acesso a serviços públicos locais, como saúde e educação, à capacidade de gerar renda. Um exemplo é o contraste entre o povoado Engenho II, localizado a 27 km de Cavalcante, e o Vão de Almas, à cerca de $60 \mathrm{~km}$ da sede do município em que se encontra, Cavalcante.

O Engenho II, onde moram cerca de 140 famílias, destaca-se entre os povoados Kalunga por ter sido beneficiado por inúmeras políticas públicas desde 2004, quando o Programa Brasil Quilombola foi lançado nesse local. Caracteriza-se por ter as moradias mais agregadas. Devido à proximidade de Cavalcante e ao seu acesso facilitado pela estrada, este povoado tem se organizado para gerar renda por meio do turismo com a oferta de serviço de guia, da provisão de serviços alimentícios e da venda do artesanato e produtos da agricultura familiar. Além disso, os moradores do Engenho II têm acesso a casas de concreto e telha, energia elétrica, telefone público, água encanada, serviços e equipamentos públicos de saúde e educação até o ensino médio. 
Em contraste, o Vão de Almas, onde residem quase 400 famílias, encontra-se mais isolado não só pela distância, mas, principalmente, em razão da estrada ruim e da ausência de transporte público até a cidade. Mais dispersas, as casas do Vão de Almas são em sua maioria de adobe e telha de palha e não possuem energia elétrica ou água encanada. A plantação de roça de subsistência constitui o único modo de produção dos quilombolas do Vão. O acesso a serviços públicos essenciais é dificultado pela ausência de posto de saúde, transporte escolar e escola de ensino médio dentro do povoado. A realidade vivida pela comunidade do Vão de Almas é a que mais se assemelha à realidade vivida nos outros agrupamentos.

A pobreza, a falta de oportunidades de inclusão socioeconômica e a ausência de serviços públicos de saneamento básico - eletrificação, saúde, educação e assistência social em grande parte da comunidade Kalunga - violam a liberdade tão almejada pelos remanescentes de quilombos ali presentes.

Os artigos $1^{\circ}$ e $2^{\circ}$ da Constituição Federal inauguram a Magna Carta com os fundamentos de cidadania e dignidade da pessoa humana. $\mathrm{O}$ art. $3^{\mathrm{o}}$ traz os Objetivos Fundamentais da República de erradicar a pobreza e a marginalização além de reduzir as desigualdades sociais e regionais. Portanto, em uma sociedade livre, justa e solidária, conforme prenuncia a Constituição no art. $3^{\circ}$. I, o Estado deve procurar equalizar as oportunidades e reduzir os riscos sociais por meio de políticas sociais focalizadas àqueles em situação de vulnerabilidade social.

O Programa Brasil Quilombola-PBQ foi lançado em 2004 com o fim de consolidar uma política de Estado para reduzir as vulnerabilidades das comunidades quilombolas por meio de uma Agenda Social Quilombola, dividida em quatro eixos de ação: acesso à terra, infraestrutura e qualidade de vida, inclusão produtiva, desenvolvimento local e direitos de cidadania.

Em junho de 2011, com o compromisso de superar a extrema pobreza, foi lançado o Programa Brasil Sem Miséria- BSM para o período de 2012 a 2015, visando à inclusão social e produtiva da população extremamente pobre por meio da elevação da renda familiar per capita, da ampliação do acesso aos serviços públicos, às ações de cidadania e de bem-estar social e da ampliação do acesso às oportunidades de ocupação e renda com base em ações de inclusão produtiva nos meios urbano e rural. Tal inclusão se dá por meio da busca ativa às 
populações mais vulneráveis, como as do meio rural, em especial aquelas de povos e comunidades tradicionais, as de periferias das metrópoles e as moradoras de rua.

O Plano Plurianual - PPA para o período de 2012 a 2015, intitulado de Plano Mais Brasil, previu orçamento específico para as agendas transversais com vistas a diminuir as desigualdades entre grupos populacionais mais vulneráveis - Igualdade Racial, Comunidades Quilombolas e outros Povos e Comunidades Tradicionais, Povos Indígenas, Políticas para Mulheres, Criança e Adolescente, Juventude, Pessoa Idosa, Pessoa com Deficiência, População em Situação de Rua, e População LGBT.

Esse PPA expressou a intenção do Governo Federal em garantir o acesso a programas ou políticas usualmente setoriais a populações e territórios mais vulneráveis, incluindo os quilombolas. O PPA 2012-2015 previu ainda ações de monitoramento, coordenação e avaliação do $\mathrm{PBQ}$, além de recorte orçamentário em 14 programas temáticos de quase todas as pastas ministeriais, contemplando 37 metas e 17 iniciativas, pactuadas no âmbito do Fórum Intergovernamental de Promoção da Igualdade Racial.

Ainda, as agendas transversais caracterizam a estratégia de desenvolvimento adotada pelo Governo Federal, que não só ampliou o investimento em políticas sociais - os gastos orçamentários da União em políticas sociais evoluíram de 12,9\% do PIB em 2000 para 16,9\% em 2012, segundo dados do Ministério do Planejamento Orçamento e Gestão (Brasil, 2013) mas também procurou institucionalizar direitos, políticas e programas de governo e arranjos de gestão que criassem condições para sua efetivação.

O processo de institucionalização deu-se por meio da criação de órgãos de articulação e gestão de políticas para públicos específicos, como o Ministério do Desenvolvimento Social e Combate à Fome, as Secretárias Especiais, que possuem status de Ministério, de Políticas para as Mulheres, de Direitos Humanos e de Políticas para a Promoção da Igualdade Racial. Além dos órgãos criados, estabeleceu-se: sistemas nacionais de políticas públicas, como o Sistema Único da Assistência Social - SUAS e o Sistema de Segurança Alimentar e Nutricional SISAN; polícias nacionais, como a Política Nacional de Promoção da Igualdade Racial e a Política Nacional de Gestão Territorial e Ambiental das Terras Indígenas; Planos Nacionais, como o Plano de Desenvolvimento Sustentável dos Povos e Comunidades Tradicionais de Matriz Africana; Conselhos, como o Conselho de Promoção da Igualdade Racial e Conselho 
de Juventude; Comissões, como a Comissão Nacional de Desenvolvimento Sustentável dos Povos e Comunidades Tradicionais; Leis, como a Lei $N^{\circ} 12.711 / 2012$, que estabeleceu a reserva de vagas em universidades e institutos federais para alunos advindos da escola pública e aplicação de cotas étnico-raciais.

Os recursos financeiros investidos, o avanço normativo de acesso a direitos das comunidades quilombolas, bem como a mobilização e articulação entre governos federais, estaduais e municipais, sociedade civil e organizações não governamentais trouxeram maior visibilidade às comunidades quilombolas e as incluíram no ciclo de elaboração, implementação, monitoramento e avaliação de políticas públicas que visam promover o desenvolvimento social.

Este trabalho pretende assim analisar a transformação da realidade com a inserção de políticas sociais no território do Quilombo Kalunga, iniciada a há quase dez anos, considerando seus efeitos sobre o desenvolvimento com maior liberdade real aos Kalunga. Permitirá, assim, analisar as relações entre os elementos que formam o espaço e verificar o movimento da totalidade no território Kalunga para uma nova realidade a partir da inserção de políticas públicas.

A importância do tema se dá a partir da consideração de que a população remanescente de quilombos foi segregada pelo Estado brasileiro, sendo por mais de um século marginalizada do processo de desenvolvimento, e tal população finalmente ganhou visibilidade frente ao poder público, com o lançamento, em 2004, de um pacote de políticas públicas articuladas e organizadas para alcançar o território dos quilombos. Torna-se, portanto, fundamental que se verifiquem os efeitos de quase 10 anos de inserção de políticas públicas com enfoque territorial no espaço quilombola e na ampliação das capacidades de sua população.

De acordo com Santos (2008), o espaço, devido a sua memória construída de técnicas, é condição da realização concreta dos modos de produção, tendo o registro de seus momentos.

O território usado pelos Kalunga é marcado pela forte relação dos Kalunga com os rios, com o cultivo da terra e com o Cerrado, tendo como seus principais modos de produção ao longo dos anos a agricultura e pecuária de subsistência, além da confecção de farinha. 
Mandioca, arroz, abóbora, feijão, milho e gergelim constituem a produção agrícola elementar dos Kalunga e, consequentemente, suas principais fontes alimentares. Os rios são fonte de água para beber, para banho, para preparação de alimentos, para lavagem de roupas e louças e para a pesca de subsistência.

Roças nos vãos de serra próximos aos rios, casas de adobe e palha com quintais preenchidos por galinhas em meio ao Cerrado formam a paisagem de grande parte dos agrupamentos Kalunga. "A roça faz parte da terra, a terra é a casa do homem. A roça e o território confundem-se. A roça, como o território, é administrada pelo grupo constituído pela família extensa, pertence aos ancestrais.” (BAIOCCHI, 2006, p.94)

Tomando o conceito central de Santos (2002), a noção de espaço como um conjunto indissociável de sistema de ações e sistema de objetos, o espaço Kalunga será caracterizado segundo as categorias de análise externas e internas ao espaço (SANTOS, 2012a).

Como categorias internas, citam-se: a paisagem, a configuração territorial, a divisão territorial do trabalho, o espaço produzido, as rugosidades e as formas-conteúdo. Como categorias externas, citam-se: a técnica, a ação, os objetos, a norma e os eventos, a totalidade e a totalização, os símbolos e as ideologias, a universalidade e a particularidade, a temporalização e a temporalidade.

O espaço geográfico proposto por Santos como sinônimo de "território usado" é fundamental para a realização da integração das políticas públicas chamadas intersetoriais. A partir do conceito de território usado - "o espaço do acontecer solidário" - será possível o entendimento da dinâmica do lugar.

Para análise das desigualdades de forças na produção do espaço, é preciso destacar que Santos (2008) diferencia o conceito de lugar e espaço, sendo o primeiro uma "porção discreta de espaço total” (p. 152). Segundo Santos, o espaço sendo definido como resultado das relações sociais evolui assim de forma diferente nos lugares. Diferenças na capacidade de aportar novos investimentos, de estabelecer regras de organização do espaço, por exemplo, levam a evoluções espaciais desiguais. 
A característica sistêmica do espaço nos permitirá compreender a relação entre a situação de vulnerabilidade dos quilombolas e a ausência do Estado, bem como os possíveis efeitos da inserção de programas sociais nas comunidades remanescentes de quilombos. Segundo Santos (2012a), as relações entre os elementos que formam o espaço, comandados pelo modo de produção dominante local, permitem dar o valor do todo, e a totalidade se movimenta para uma nova realidade do todo quando uma variável se modifica. As condições socioeconômicas e os momentos históricos dos lugares geográficos, do ponto de vista sistêmico, caracterizam a evolução desigual do espaço.

Ao entender a centralidade do território étnico na formulação e implementação de políticas públicas, o Estado brasileiro deu um grande passo rumo ao enfrentamento das desigualdades. Em Por uma outra Globalização (2012b), Milton Santos explicita a centralidade do território:

Nesse começo dos tempos, os laços entre território, política, economia, cultura e linguagem eram transparentes. (...) A economia e a cultura dependiam do território, a linguagem era uma emanação do uso do território pela economia e pela cultura (...) em todas as manifestações essenciais de sua existência, os moradores pertenciam àquilo que lhes pertencia, isto é, o território" (SANTOS, 2012b, p.62)

O PBQ, voltado para um território étnico e para a promoção da igualdade racial, e o BSM, com a meta de erradicar a extrema pobreza, representam duas grandes experiências do Governo brasileiro na formação de redes de coordenação para agir coletivamente em busca da eficiência e eficácia de seus programas.

O alcance de metas e objetivos complexos como os do PBQ e do BSM, no entanto, demanda uma ação igualmente complexa que põe em jogo interesses políticos, expectativa popular, alta carga de trabalho e responsabilidade para a administração pública em todas as esferas federativas, operações e decisões conflitivas, levando em consideração que:

Los errores de diseño y los defectos de implementación son más comunes, obviamente, en las políticas sociales que enfrentan problemas cuyos componentes y factores explicativos arraigan en realidades vitales de difícil acceso e incidencia gubernamental (VILLANUEVA, 1993, p.17).

A decisão do Governo Federal pelo alinhamento de múltiplos atores no desenho e implementação de políticas públicas parte de princípios de conhecimento comum sobre trabalho em equipe, mas que, com a cultura de competitividade e individualismo disseminada 
nas relações de trabalho, mesmo os Estados que visam o bem estar social encontram dificuldades em colocar esse conhecimento na prática de administração pública.

Brugué (2008, p.5) resume a dificuldade de se implementar uma rede de políticas públicas em três frases: Solos somos impotentes, La suma no suma e El reto es como juntarnos para multiplicar. Os cidadãos brasileiros merecem respostas racionais, conciliadoras e integrais a seus problemas, que devem partir de áreas que conhecem os problemas a serem enfrentados por todas as políticas setoriais, evitando superposição e lacunas.

Esclarecido o olhar que se lançará sobre as políticas públicas e o espaço, este trabalho pretende verificar os efeitos das políticas sociais no espaço e no desenvolvimento da comunidade Kalunga. Como referência conceitual de desenvolvimento será considerado o de Desenvolvimento como Liberdade (2010) de Amartya Sen, que pressupõe que o desenvolvimento somente é possibilitado se houver a remoção das principais fontes de privação de liberdade, tais como pobreza, falta de oportunidade econômica e não acesso a serviços públicos.

Segundo SEN (2010, p.16), para haver desenvolvimento é preciso que se

[...] removam as principais fontes de privação da liberdade: pobreza e tirania, carência de oportunidades econômicas e destituição social sistemática, negligência dos serviços públicos e intolerância excessiva de Estados repressivos.

Sen (2010) considera a pobreza na perspectiva da privação de capacidades básicas, sem negar que a baixa renda ou a falta dela sejam a maior causa da pobreza e, consequentemente, da privação de capacidades. A variação entre renda e capacidade seria acentuada em grupos populacionais de acordo com a idade, sexo e localizações geográficas, que podem limitar a possibilidade de certos grupos converterem renda em capacidade. $\mathrm{O}$ aumento da capacidade de sobrevivência aumenta a produtividade, que leva a um maior poder de auferir renda.

Da mesma forma, quanto melhor o acesso à educação básica e saúde, maior a qualidade de vida e o potencial de auferir renda. A pobreza é entendida primariamente como a "privação da vida que as pessoas podem levar e das liberdades que elas realmente têm". (SEN, 2010, p. 126). 
Por fim, em uma abordagem de desenvolvimento como liberdade, a liberdade de participação social deve ser central na análise de políticas públicas. A avaliação das políticas públicas propostas no Programa Brasil Quilombola do Governo Federal deve primeiramente considerar o nível de participação dos quilombolas na elaboração e implementação do Programa. Ao adotar o conceito de desenvolvimento de Sen é necessário ampliar o leque de indicadores para além dos indicadores de renda. Assim, serão considerados indicadores relacionados à melhoria da qualidade de vida como: a redução do analfabetismo, acesso à educação, acesso à saúde, erradicação do trabalho infantil e da desnutrição.

Assim, a efetividade das políticas públicas no espaço Kalunga será medida de acordo com aumento das capacidades e consequentemente das liberdades reais dos Kalunga.

Pensar um projeto de pesquisa geográfico necessariamente passa pelo estudo da totalidade presente em um determinado espaço. O nexo e a coerência do tema de estudo escolhido estão intrinsicamente relacionados às categorias dos saberes espaciais e suas escalas analisadas. Segundo Moreira (2012, p.17),

[...] cinco eixos de reflexão indicam em nossos dias o desenvolvimento de uma onda crítica no pensamento geográfico: o espaço como formação social (Santos, 1978); o espaço como reprodução das relações de produção (Lefebvre, 1974); o espaço como mediação das relações de dominação de classes e poder (Lacoste, 1977); o espaço como estrutura de valorização do capital (Harvey, 1977); e a sociedade como natureza socializada e história naturalizada (QUAINI, 1979).

As relações espaciais são o eixo epistêmico e orientador do discurso geográfico, tendo o marxismo como uma referência analítico-reflexiva. Portanto, neste trabalho de análise dos efeitos no espaço, bem como dos limites e possibilidades das políticas públicas, será adotado o conceito de espaço como um conjunto indissociável de sistemas de objetos e sistemas de ações (SANTOS, 2006).

Nessa perspectiva, considerando as análises apresentadas por Sposito, o método deve ser considerado como um

Instrumento intelectual e racional que possibilite a apreensão da realidade objetiva pelo investigador, quando este pretende fazer uma leitura dessa realidade e estabelecer verdades científicas para a sua interpretação (SPOSITO, 2004, p.24). 
Para Sposito (2004), é preciso ter um método adequado para compreender a realidade. Considerando as contribuições desse autor, o método dialético se apresenta como a alternativa mais viável para o desenvolvimento da presente pesquisa. O método dialético, que confronta um pensamento do senso comum com um novo pensamento, permitirá criar a tensão necessária para gerar conhecimento em políticas públicas, delineando seus limites e abrindo portas para novos conceitos. Para isso, será necessário esclarecer e desmistificar velhos conceitos em políticas públicas, tendo o espaço como sua principal categoria, deixando em evidência as contradições existentes no objeto a ser pesquisado.

Adotando uma postura lógica e não neutra, o método dialético permite interpretar a realidade por meio da análise do discurso e da incorporação de dados contraditórios que permitam conceituar suas causalidades. Sendo dialética uma "ferramenta, um instrumento com potencial revelador de realidades construídas socialmente por contrapor ideias, fatos e ser capaz de (re)pensar o presente" (SERRANO, 2014, p.10), esta tem o grande potencial de nortear o pesquisador a interpretar a realidade e o movimento do espaço.

Lefebvre, apud SOJA (1993), afirma que a dialética já não é a mesma de Marx e Engels, assim como a deles já não era mais a de Hegel, e que, portanto, deve ser trazida para outro patamar de análise e discussão.

Assim, a postura do pesquisador deve sobretudo ser crítica do ponto de vista lógico e intelectual. Isso não quer dizer que deve haver julgamento depreciativo e acusativo, mas um exame cuidadoso e criterioso, buscando dados e informações comparáveis, a fim de contextualizar ideias que vão além do senso comum.

Segundo Sposito (2004, p.67), a "leitura do pensamento geográfico deve ser feita mediante uma reflexão 'radical' (buscar a origem do problema), e total (inserir o objeto da nossa reflexão no contexto do qual é conteúdo)". Portanto, na análise de políticas públicas deve-se considerar a realidade social e as articulações entre os diferentes sistemas e estruturas ali presentes, a fim de averiguar o efeito da ação externa do Estado, como vetor para o desenvolvimento.

De acordo com Santos (2012), por mais lógico que seja o método construído, o pesquisador encontrará dificuldades para sua realização devido, entre outros, às limitações 
relacionadas à complexidade e ao dinamismo da realidade a analisar, do número e da representatividade dos dados disponíveis.

São necessários, contudo, amplo conhecimento e compreensão dos objetos e objetivos do estudo, a fim de permitir, a partir de uma hipótese e uma antítese, chegar à síntese. Nesse movimento de respeitar os paradigmas para depois se opor ao pensamento comum, esperamos poder contribuir para o pensamento geográfico e com a formulação e implementação de políticas públicas.

Para se obter o máximo das novas ideias produzidas no campo científico, é essencial compreender a realidade no tempo e no espaço, estando, ao mesmo tempo, ciente das complexidades do método e das limitações que possam surgir decorrentes dos aspectos ideológicos, presentes no cotidiano do pesquisador (Sposito, 2004).

Dessa forma, os vários elementos contidos no método devem ser considerados, quais sejam: a doutrina, a teoria, as leis, os conceitos e as categorias, conforme sugerido por Sposito. Ao final, a partir de uma base existente, será possível estabelecer novos olhares sobre uma mesma problemática, na perspectiva de dialeticamente ter contribuído para fomentar as discussões e quem sabe, não pretensiosamente, chegar a novas proposições para a problemática das políticas públicas e das vertentes do desenvolvimento no espaço adotado como objeto de análise.

Analisaremos os processos socioespaciais, entendendo estes como a produção social do espaço no capitalismo e as formas de intervenção do Estado. A produção social do espaço pode ser representada pela configuração territorial da comunidade Kalunga, corte espacial deste estudo, e suas relações com vulnerabilidade social - educação, renda, seguridade social, qualidade dos domicílios, acesso a serviços públicos e segurança alimentar.

As intervenções do Estado serão analisadas de acordo com o nível de acesso dessa comunidade a programas sociais e à titulação da terra, o que nos levará a conclusões sobre a inclusão dos remanescentes de quilombo no processo de desenvolvimento do Estado brasileiro. 
Portanto, tendo como objeto as políticas públicas de inclusão socioeconômica no espaço quilombola, esta pesquisa tem o objetivo geral de identificar e discutir os efeitos de políticas públicas articuladas para o território quilombola na comunidade Kalunga, localizada nos municípios de Cavalcante, Monte Alegre e Teresina de Goiás, na mesorregião do Nordeste Goiano.

Os objetivos específicos são discutidos em cada capítulo desta dissertação. No capítulo 1 pretendeu-se discorrer sobre as limitações e possibilidades do território Kalunga de acordo com a sua formação socioespacial e o nível de acesso de sua população aos direitos sociais básicos. O capítulo 2 se propôs a analisar a coordenação, articulação e implementação de políticas públicas sociais nos municípios que abrangem o Território Kalunga e como elas refletem sobre o desenvolvimento da comunidade Kalunga. Finalmente, o capítulo 3 traz uma reflexão sobre o aumento das liberdades substantivas e das capacidades dos Kalunga a partir da análise de dados de pesquisa quantitativa realizada pela DATAUFF/PNUD/MDS em 2011 e da análise das falas e fatos observados em pesquisa etnográfica realizada por esta pesquisadora em 2015.

A hipótese é que a inserção de políticas públicas que visam reduzir a pobreza bem como aumentar o acesso a serviços públicos e as oportunidades de inclusão socioeconômica permitem aumentar a capacidade e a liberdade dos indivíduos, diminuindo a desigualdade no território.

Para análise dos dados quantitativos sobre as políticas públicas no território Kalunga serão considerados dados de monitoramento dos Programas Brasil Quilombola e Brasil Sem Miséria encontrados nos sítios eletrônicos dos principais órgãos responsáveis pela a coordenação e implementação de seus programas, em especial da Secretaria Especial de Promoção da Igualdade Racial-SEPPIR, da Fundação Cultural Palmares e do Ministério do Desenvolvimento Social e Combate à Fome. Outra fonte importante de informação é o Relatório de Gestão do Programa Brasil Quilombola 2013.

Para considerações sobre o grau de vulnerabilidade socioeconômica das comunidades quilombolas em nível nacional e, em especial, sobre a comunidade Kalunga, serão analisados os dados quantitativos da Pesquisa, contratada pelo MDS em parceria com o Programa das Nações Unidas para o Desenvolvimento-PNUD, “Avaliação da Situação de Segurança 
Alimentar e Nutricional em Comunidades Quilombolas Tituladas" (Censo), cuja coleta de dados foi realizada entre abril e setembro de 2011 e seus resultados entregues em 2013 pelo Núcleo de Pesquisas de Avaliação de Políticas Públicas da Universidade Federal Fluminense (DataUFF).

A referida pesquisa constitui a principal fonte de informação sobre o grau de vulnerabilidade das famílias quilombolas, pois fornece informação atualizada e censitária sobre a composição familiar, a caracterização dos moradores e dos domicílios, o acesso a serviços públicos e programas sociais, a situação de segurança alimentar e nutricional, a produção, trabalho e renda de todas as comunidades tituladas, entre elas a Kalunga.

Para estudo comparativo dos municípios que abrangem o território da Comunidade Kalunga, com enfoque nas diferenças entre dados espaciais - urbanos e rurais - e étnicoraciais - negros e brancos, são analisados os dados do Censo 2010 - IBGE.

Apesar de o Censo não trazer dados que permitam o recorte territorial quilombola, traz informações sócio econômicas importantes sobre a população e os municípios que abrangem o território Kalunga, sendo a base para o planejamento das políticas públicas federais, estaduais e locais. Com isso, é possível atingir o primeiro objetivo específico.

Foi realizada pesquisa de campo com o objetivo de observar e compreender como a inserção ou a ausência de políticas públicas afetam a qualidade de vida e a liberdade dos Kalunga. O trabalho de campo teve como base a pesquisa etnográfica, tendo tido como principais instrumentos a observação participante e entrevistas aprofundadas. A primeira imersão no campo deu-se entre os dias 9 e 13 de fevereiro nas comunidades do Engenho e Vão do Moleque no município de Cavalcante, Goiás. A segunda viagem ocorreu entre os dias 10 e 14 de março na comunidade do Vão de Almas, e a terceira entre os dias 18 e 20 de março, para conversa com o líder da Associação Quilombo Kalunga, e nova inserção no Vão de Almas para uma festa de São José.

A escolha pela entrevista aprofundada, em que o número de entrevistados perde relevância diante da imensidão de informações e interação que se ganha quando o pesquisador permite-se aproximar-se do pesquisado, deveu-se ao fato de que os dados da comunidade Kalunga foram disponibilizados pelo MDS por meio da Pesquisa de Segurança Alimentar 
Quilombola, divulgada em 2013. Portanto, a porcentagem ou número de moradores da comunidade que acessam os programas governamentais e políticas públicas já era de conhecimento da pesquisadora ao imergir no campo.

Tendo realizado a análise desses dados previamente, esta pesquisadora esperava observar o espaço, ouvir as conversas e interações entre os Kalunga, conversar com eles e entender seu ponto de vista sobre os temas apresentados. Para permitir a interação de entrevista aprofundada, para a qual não foi apresentado questionário estruturado nem semiestruturado, foi utilizado um roteiro que permitisse a esta pesquisadora verificar a compreensão dos Kalunga quanto ao seu acesso às políticas públicas e programas governamentais, além dos seus efeitos sobre a expansão de suas capacidades e liberdades tais como: educação básica, acesso à renda, à assistência médica, ao trabalho, ao mercado, à participação política, entre outros. Segundo Beaud and Weber (p. 119):

“...cada entrevista aprofundada é um fato que é preciso analisar por si mesmo; é uma interação pessoal em que cada um se empenha fortemente e é, também, uma interação solene com um mínimo de encenação e de cerimonial (o gravador serve aqui de "espectador" indispensável). Distingue-se da "distribuição de um questionário", uma relação anônima e sem futuro; difere também das interações pessoais habituais e constitui uma espécie de misto entre interação pessoal e cerimônia".

A relação entre entrevistador e entrevistado na pesquisa aprofundada requer uma certa habilidade do pesquisador para continuar a conversa e uma certa empatia do entrevistado com o pesquisador para falar abertamente, sem cerimônia. "A entrevista etnográfica tem como motor essa relação social particular que é a relação pesquisador/pesquisado" (Beaude and Weber, p. 120).

Foi importante explicar muito bem o principal objetivo da pesquisa antes de se iniciar, para que a "conversa" tivesse um foco específico e não se tornasse somente, por que um pouco acaba sendo, um desabafo. Foi usada a palavra "conversa" no lugar de entrevista, pois essa era realmente a dinâmica. O termo "fazer uma entrevista" poderia levá-los a pensar que teriam que responder a um questionário em uma prancheta, o que não ocorreu. $\mathrm{O}$ roteiro, que estava anotado em um caderno, não era rígido. A conversa com o entrevistado era normalmente "livre" para que ele pudesse apontar os pontos que mais lhe afetavam em 
relação aos efeitos das políticas públicas, ou da falta delas.

Em grande parte do início da conversa, a reação era de "estou à disposição" mas com um certo ar de desconfiança. Após cerca de 10 minutos de conversa, quando eles percebiam que não tinham que responder questionários e que o ponto de vista deles era valorizado na interação, é que eles relaxavam e falavam mais abertamente. Só então é que a pesquisadora solicitava permissão para gravar, sempre com muito cuidado: "Tudo que você está falando está tão interessante, tenho medo de esquecer depois, você permite que eu grave?’. E então os entrevistados davam a permissão sem nenhuma restrição. Com base na pesquisa etnográfica, tentou-se ao máximo valorizar o caráter dialógico e intersubjetivo entre pesquisadora e pesquisado.

O trabalho de campo, se é que pode se chamar de "trabalho", foi intensamente enriquecedor e definidor dos rumos da pesquisa. A possibilidade de viver o instante vivido junto aos Kalunga entrevistados - sem desconsiderar a intencionalidade da pesquisadora e dos pesquisados para que as conversas, embora tenham tido o máximo possível um aspecto mais natural, fossem profícuas para ambas as partes - foi importante para entender a liberdade dos Kalunga a partir do seu lugar.

Após realização da análise de dados socioeconômicos do território, da ação de políticas públicas no espaço e da vivência da população Kalunga, foi possível, a partir da teoria do espaço geográfico e do desenvolvimento como liberdade, checar a hipótese de que a inserção de políticas públicas que visam reduzir a pobreza bem como aumentar o acesso a serviços públicos e as oportunidades de inclusão socioeconômica permitem aumentar a capacidade e a liberdade dos indivíduos, diminuindo a desigualdade no território.

Como já foi dito, ao se especificar o tratamento dos objetivos específicos, este trabalho será composto de três capítulos:

O primeiro, intitulado "Construção da territorialidade e espacialidade Kalunga", pretende abordar a territorialização Kalunga, com o objetivo de discorrer sobre as limitações e possibilidades do território Kalunga de acordo com a sua formação socioespacial e o nível de acesso de sua população aos direitos sociais básicos. Assim, o capítulo 1 discorre sobre a luta dos quilombolas pelo território e o processo histórico da conquista de direitos junto ao Estado, 
perpassando a legislação que assegura desde o direito territorial aos direitos sociais. Por fim, fornece uma análise socioeconômica do Quilombo Kalunga.

O Capítulo 2 intitulado "Políticas públicas e desenvolvimento" abordará o tema da pobreza e da desigualdade como restrição à liberdade de um povo. Pretende-se discorrer sobre a expansão do conceito de desenvolvimento, tendo as liberdades substantivas como referência avaliativa da efetividade de políticas públicas voltadas para territórios quilombolas. Além disso, pretende-se analisar a coordenação, articulação e implementação de políticas públicas sociais previstas no Programa Brasil Quilombola, composto de um conjunto de políticas públicas sociais lançadas em 2004 pelo Governo Federal com o fim de consolidar uma política de Estado para os territórios quilombolas. Tendo como referência o conceito de desenvolvimento como liberdade de Amartya Sen e com base nos resultados divulgados oficialmente pelo Governo Federal, cotejados com os relatos dos Kalunga, será feita análise da efetividade das políticas sociais nesses territórios.

O capítulo 3 denominado "Memória viva e liberdade Kalunga" tem o objetivo de refletir sobre a vivência dos Kalunga e a expansão de suas liberdades substantivas, tais como participação política, acesso à renda, à produção e ao consumo, acesso à serviços públicos de saúde, educação e assistência social, entre outros. Será relatada a reflexão dos Kalunga, resultante de pesquisa de campo, sobre as mudanças espaciais ocorridas onde as políticas sociais alcançaram o território e sobre seus efeitos na liberdade e autonomia dos Kalunga, sem deixar de mencionar os efeitos da ausência de políticas públicas na expansão de suas capacidades.

Este trabalho não pretende discutir os reflexos da política social na cultura ou nas tradições do povo Kalunga. O principal objetivo é refletir sobre os efeitos de políticas públicas sociais nas liberdades conquistadas com a possível redução da miséria e da pobreza e no desenvolvimento das capacidades do povo Kalunga para buscar sua autonomia e emancipação de seu território. 


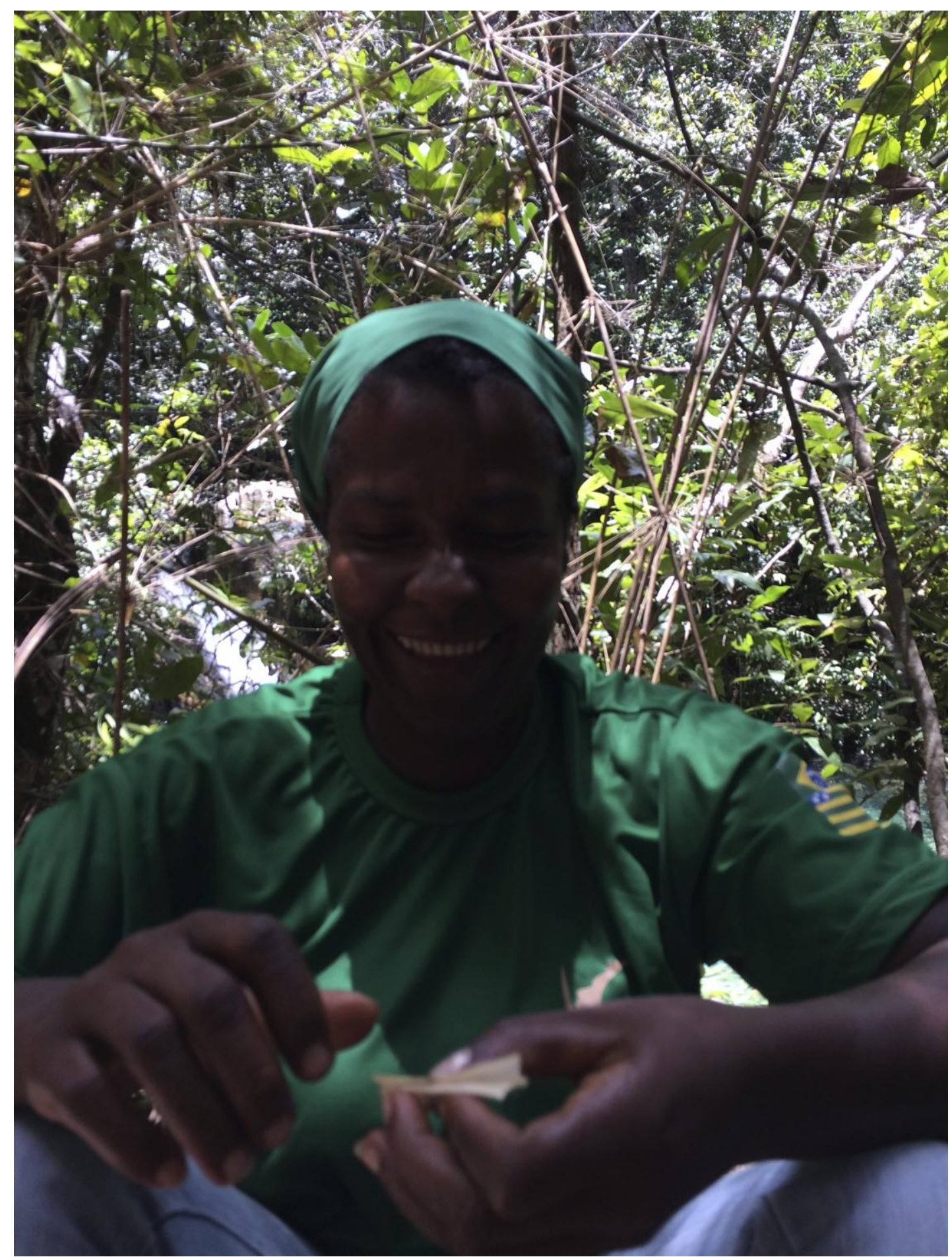

"Aqui ninguém tira os filhos da escola para por os filhos para trabalhar [...] Quem sofreu o analfabetismo sabe o quanto dói. Por isso nenhum mãe ou pai faz isso. Tem muitos pais e mães analfabetos nessa nossa região e eles sabem o quanto dói a gente ser analfabeto". "”.

Rita Pereira Tartuliane, Kalunga, 44 Anos, 8 Filhos, sendo 7 Vivos. 


\section{CAPÍTULO 1}

\section{CONSTRUÇÃO DA TERRITORIALIDADE E ESPACIALIDADE KALUNGA}

\subsection{A BUSCA PELA LIBERDADE}

A palavra quilombo deriva-se da língua africana Kimbundo, de cultura banto, nativa de Angola, significando lugar cerrado e fortificado, e simboliza o direito de ser livre e de se organizar (SILVA, 2008). Essa palavra carregada de significado que remete a termos como resistência, violência e liberdade simboliza a luta dos negros por um território de independência para uso próprio, sem donos, sem correntes, sem chicote. Representa a união e solidariedade entre iguais para buscar novas formas de reprodução social.

Tendo como referência a base territorial, os remanescentes de quilombo encontraram um caminho para construção de geografia e história próprias. A temática da história dos quilombolas no Brasil foi excluída dos livros de história do Brasil até meados dos anos 1970. Historiadores recentes recorrem à oralidade, catálogos de jornais e documentos cartoriais em sua busca de evidenciar a intencionalidade do Estado de esconder e deixar escondida a memória de um povo "marginalizado".

Para entender a totalidade ${ }^{1}$, recorreu-se a dissertações de mestrado e livros de história a fim de compreender a evolução do lugar Kalunga. No entanto, o objeto da análise deste estudo é a realidade social presente, sendo a breve descrição histórica apenas um meio para apreender o espaço, as linhas de força e o futuro possível para a Comunidade Kalunga.

Silva (2008), no livro "Quilombos do Brasil Central”, traz um "entrelaçamento de dados" oriundos de "pesquisa interdisciplinar profunda" para registrar o movimento que levou

\footnotetext{
${ }^{1}$ No livro "A Natureza do Espaço", Santos considera a noção de totalidade como "um elemento fundamental para o conhecimento e análise da realidade" (p.115), sendo que a totalidade não é apenas uma soma das partes. Nas palavras de Santos: As partes que formam a Totalidade não bastam para explicá-la. Ao contrário, é a Totalidade que explica as partes. A Totalidade B, ou seja o resultado do movimento de transformação da Totalidade A, divide-se novamente em partes. As partes que correspondem à totalidade $B$ já não são as mesmas partes correspondentes à Totalidade $A(2006, p .115$ e 116).
} 
os Kalunga aos vãos de serra do Rio Paranã. Não se sabe ao certo quantos negros chegaram ali fugidos, alforriados ou senhores de sua liberdade, após comprá-la com bastante sacrifício.

Os quilombolas procuravam uma alternativa de vida livre. Segundo Silva, registros encontrados nos Cartórios de Goiás demonstram que grande parte conseguiu a carta de alforria por meio de negociação com seus senhores, que a trocavam por trabalho na roça, pedras de ouro, entre outros. Há ainda registros de ilícito penais de furtos, acredita-se que para conseguir o dinheiro para comprar a liberdade, e de homicídios, como forma de mostrar sua resistência àquele regime de opressão.

Porém, as fugas, resultantes de longo período de repressão e violência do sistema escravista, são a origem mais comum da formação dos quilombos no Brasil, que tinham como modos de produção principais a mineração do ouro, a caça, a pesca e agricultura de subsistência coletiva. Há mais de 240 anos, nos vãos da Serra Geral (SILVA, 2008), no nordeste goiano, os remanescentes de quilombo Kalunga, descendem de escravos que, acredita-se, tenham sido levados ao Goiás em comboios originados da Bahia durante o século XVIII, quando os Bandeirantes paulistas chegaram ao estado goiano para exploração das minas de ouro nas fazendas goianas.

O livro "Uma História do Povo Kalunga" (Brasil, 2001) conta que a chegada do Bandeirante Bartolomeu Bueno da Silva em 1722 às terras que, naquela época, vieram a ser chamadas de "minas dos Goiases" marca a chegada dos mineradores e, consequentemente, de seus escravos, que vieram a fugir e se esconder nos vãos das serras do Mendes, do Mocambo, da Mangabeira, do Bom Jardim, da Areia, de São Pedro, do Moleque, da Boa Vista, da Contenda, do Bom Despacho, do Maquine e da Ursa. Grupos de quilombos foram se formando em Monte Alegre, Cavalcante, Arrais e Tocantins, fazendo com que o governo se sentisse ameaçado e ordenasse a destruição de seus ajuntamentos, levando os negros a procurar lugares mais íngremes e isolados, em busca de sua liberdade.

Nos vãos de serra do cerrado da Chapada, os negros fugidos procuraram refúgio e encontraram povos indígenas como os Acroá, Capepuxi, Xacriabá, Xavante, Kaiapó, Karajá, Avá-Canoeiro, que habitavam o planalto goiano, escondendo-se dos bandeirantes para não serem escravizados. Ali foram se juntando também outros quilombolas fugidos dos garimpos ou alforriados, por meio da compra de sua liberdade, quando o ciclo do ouro decaiu. 
Abriram-se fazendas e sítios nos vales do Paranã, que significavam a esperança de um modo de vida mais digno com autonomia e emancipação. Como os negros eram a maioria, ali se formaram o que chamavam de terras de preto, pois pertenciam às famílias de escravos e ex-escravos, que tinham a posse, mas não o documento de título de propriedade.

A terra foi assim passando entre gerações de famílias, que dividiam os pedaços de terra na produção da mandioca, dando origem ao povo Kalunga. Baiocchi (2006, p. 14), no livro Kalunga: povo da terra, fala sobre o modo de vida rural de um povo isolado:

Os Kalunga remetem-nos à África, quando o isolamento geográfico cultural possibilita a reificação das tradições e costumes. Metodologicamente são vistos como descendentes de escravos que, à deriva da sociedade institucional, constroem uma cultura própria tendo como parâmetro sua história de grupo "isolado", uma vez que como um quilombo, delimitam fronteiras e, coletivamente, seguem uma história e uma cultura peculiares. Como especificidade, os Kalunga põem em pauta a discussão da historicidade dos quilombos enquanto luta, resistência, lugar de moradia e construção de uma nova vida, mas não se esgota o seu perfil de "lavrador negro" e "comunidade negra isolada no mundo rural.

A constituição do território Kalunga tem processos variados de formação - desde a ocupação livre à compra e herança, porém esse território tem em comum com todos os territórios de remanescentes de quilombos a atual luta política pela garantia legítima de titulação de suas terras, cujo direito de posse não deve ser questionado. Segundo Oliveira (2001, p. 256):

O direito de posse aparece tendo como substrato uma terra que se define e se constitui a partir da morada e cultivo. A morada (casa -domicílio - família) é a base da organização do trabalho e da produção, e efetiva através dela, o direito à terra.

Localizado no nordeste goiano, na microrregião da Chapada dos Veadeiros, o território Kalunga proporcionou a liberdade de milhares de remanescentes de quilombo de Goiás, que têm se utilizado da natureza para construção de seu modo de vida.

Saberes tradicionais como o uso de plantas medicinais e de frutos do cerrado para a alimentação caracterizam a relação harmônica dos Kalunga com a natureza. Conhecendo os ritmos das chuvas, os cursos dos rios e as terras boas de plantar, os Kalunga têm na terra o principal meio para garantir seu modo de vida baseado na agricultura familiar de subsistência. 
O advento de políticas desenvolvimentistas nacionais e estaduais não alcançaram o território Kalunga. A construção da capital federal no cerrado goiano pretendia levar o desenvolvimento para o interior do Brasil. Porém o conceito liberal de desenvolvimento acreditava que a expansão de fazendas, implantação de projetos de mineração e usina hidrelétricas juntamente com a construção de estradas trariam progresso para os locais.

Porém, o impacto sentido foi a destruição das matas nativas com a multiplicação de garimpos de ouro, cassiterita, tantalita, manganês e cristal de rocha, além da extração de calcário e brita para a construção civil. Outra externalidade foi a introdução de pessoas de fora que vieram a ser os posseiros e grileiros que ainda hoje disputam as terras tradicionalmente conquistada pelos Kalunga.

Em 1983, a entrada dessa gente de fora no território Kalunga era já um transtorno para a população espalhada no município de Monte Alegre, na Contenda, no Riachão, Sucuri, Saco Grande, Areia, Curral de Taboca ou Tinguizal. E isso era porque os moradores, embora vivessem ali por muito mais de 100 anos, não podiam comprovar que eram donos daquelas terras. Porque ali ninguém tinha qualquer documento de propriedade. (BRASIL, 2001, p. 77)

O Instituto do Desenvolvimento Agrário de Goiás- IDAGO foi então mobilizado para realizar a vistoria, medição e demarcação do território usado pelos Kalunga a fim de providenciar a titulação de suas glebas. Entre 1984 e 1985, somente os moradores da margem direita do Rio Paranã tiveram seus títulos entregues, o que levou um maior número de pessoas a invadir o território e a também passar a reivindicar a regularização da propriedade das terras. Os conflitos então só se agravaram, conforme relatado em "Uma história do povo Kalunga” (BRASIL, 2001, p. 77-78):

[...] em 1989, os moradores passaram a ser perseguidos de forma brutal pelos fazendeiros. Eles armavam tocaia para matar pais de família indefesos, queimavam casas e expulsavam famílias inteiras de suas moradas, mesmo velhos e crianças. Depois, passaram a soltar manadas de búfalos nas roças, matar a criação e poluir os rios com mercúrio. Tudo para obrigar os moradores do Kalunga a entregar suas terras àquela gente que chegava de fora.

Então, a população do Vão do Moleque, Vão de Almas e Ribeirão dos Bois se viu acuada. Recuaram para a beira dos rios, foram se amontoando em pés de serra e à margem das estradas. Impedidos de plantar, já estavam passando fome, quando a comunidade se mobilizou em busca de ajuda. A denúncia sobre o que estava acontecendo ali foi encaminhada ao governo, pedindo que 
se tomassem medidas urgentes. Com a intervenção das autoridades, foi possível controlar a violência mais brutal dos fazendeiros. Mas nem por isso o povo Kalunga que havia perdido suas terras conseguiu recuperá-las.

Como consequência dos conflitos, iniciou-se o processo de êxodo dos Kalunga de seu território rumo à área urbana de Teresina, Monte Alegre e Cavalcante em condições precárias, aumentando também a pobreza nesses municípios, já carentes de infraestrutura e de geração de emprego e renda.

Outro fator impactante na emigração dos Kalunga de seu território foi a notícia, em 1987, da construção da companhia hidrelétrica de Furnas, que resultaria na inundação de grande parte do território. Porém, a comunidade se organizou e, com o apoio de pesquisadores da Universidade de Goiás, organizou a documentação que comprovasse a necessidade de impedir a realização de tal obra. Em 1990, o canteiro de obras já instalado foi retirado.

Essa foi somente mais uma luta vencida pelos remanescente de quilombo Kalunga na sua busca pela liberdade. Ainda prossegue o conflito com fazendeiros e busca pelos documentos de titulação da terra, cujo processo histórico é descrito mais adiante.

O território, segundo Haesbaert (2005), está intrinsecamente relacionado a poder, podendo ser o tradicional poder político, ou o poder no sentido mais amplo de dominação ou no sentido simbólico de apropriação. Assim o processo de territorialização incorpora múltiplos agentes, sejam eles políticos, econômicos ou culturais.

O território Kalunga é um exemplo do que Haesbaert (2005) chama de "território simbólico", cuja manifestação se dá na importância dele como abrigo e base da manutenção de sua cultura, sem desconsiderar seu caráter funcional de prover recursos para a sobrevivência e reprodução social dos Kalunga. Sua importância pode ser verificada no discurso destacado aqui de uma mulher Kalunga em Seminário realizado pelo Conselho Federal de Psicologia sobre a questão da terra:

Os calungas, ou os quilombos, há uns 50 anos, viviam em grupos, quase iguais a índios. Viviam em comunidades, plantavam juntos, cresciam juntos, criavam juntos, tudo deles era coletivo, mas chegou um tempo em que o reconhecimento das suas terras foi chegando ao conhecimentos dos fazendeiros, e, com a ambição, foram sendo griladas. Hoje eles vivem sem terra, separados, humilhados, praticamente sem ter lugar onde plantar, e ainda digo o seguinte: humilhados ainda mais pelo governo, mesmo. Além 
de não terem as próprias terras para plantar, ainda servem de alvo de propaganda, quando são feitas propagandas dos quilombos que mentem ao dizer que os quilombos têm tudo, principalmente o dos calungas. Dizem que têm terra, que as terras já foram dadas para eles e que já receberam muito benefícios. Não é verdade. (Deuselina Francisco de Sousa, 2006)

A disputa com fazendeiros ressaltada na fala de Dona Deuselina ilustra o processo sofrido de territorialização dos Kalunga, que veem no território a fonte dos recursos materiais e seu meio de produção além de ser o símbolo de identificação do grupo. "[...] muitas vezes, por exemplo, é entre aqueles que estão mais destituídos de seus recursos materiais que aparecem formas as mais radicais de apego às identidades territoriais" (HAESBAERT, 2005, p. 6777). 


\subsection{TERRITORIALIDADE}

A luta do negro pelo território, a exemplo da Revolta dos Búzios no século XIX e a criação do Movimento Negro Unificado -MNU na década de 70, possibilitou estudos e mobilizações que levaram ao reconhecimento na Constituição Federal do Brasil dos territórios das comunidades remanescentes de quilombos como espaços de liberdade e uso coletivo. A promulgação da Constituição de 1988 trouxe o reconhecimento dos quilombolas como categoria de acesso a direitos ao, finalmente, reconhecer seus direitos territoriais no artigo 68 do Ato das Disposições Constitucionais Transitórias-ADCT.

Preceitua o artigo 68 do ADCT: "Aos remanescentes das comunidades dos quilombos que estejam ocupando suas terras é reconhecida a propriedade definitiva, devendo o Estado emitir-lhes os títulos respectivos". Destaca-se que o termo "é reconhecida a propriedade definitiva" deixa claro que os constituintes já entendiam que havia o sentido de propriedade das terras pelos remanescentes de quilombo em momento anterior à promulgação da Carta Magna, que vem conferir a certeza do direito, dando segurança jurídica aos remanescentes de quilombos dos seus territórios.

O enunciado constitucional também obriga o Estado a emitir os títulos de propriedade da terra aos remanescentes de quilombo. No entanto, o Estado brasileiro levou onze anos para realizar a primeira tentativa de regulamentar o processo de titulação das terras. Por meio do Decreto no 3.912, de 10 de setembro de $2001^{2}$, o então Presidente da República, Fernando Henrique Cardoso, estabelece procedimentos administrativos para emissão do título da terra,

1. ${ }^{2} \mathrm{O}$ Governo FHC produziu três peças acerca do citado artigo constitucional: uma Medida Provisória, transformada em um Decreto presidencial em 2001 (no 3.912, de 10.09.2001), um parecer da Casa Civil (no. 1490, do mesmo dia) e a Mensagem Presidencial 370, de 2002, publicada como justificativa do veto ao Projeto de Lei de 1997, que já estava pronto para ser sancionado. O fundamental dos seus argumentos e impedimentos pode ser resumido nos seguintes pontos: (a) 2001 era estabelecido como prazo máximo para o encaminhamento das demandas por regularização fundiária quilombola, depois do que elas dependeriam de votação de lei especial; (b) entre os critérios de reconhecimento passava-se a exigir que as comunidades comprovassem uma história de cem anos de "posse pacífica" da terra, desde 13 de maio de 1888, até a data de promulgação da Constituição de 1988; (c) as terras destinadas aos remanescentes de quilombos passavam a ser consideradas não passíveis de desapropriação, porque se supunha serem todas devolutas; (d) declarava que o direito estabelecido na Constituição dizia respeito aos indivíduos "remanescentes das comunidades de quilombos" e não às "comunidades". Este último ponto era acrescido como estratégia de descaracterizar os direitos territoriais quilombolas como direitos coletivos, de forma a impedir a continuidade da atuação do Ministério Público Federal (Arruti, 2009, p. 85). 
mas seu Art. $1^{\circ}$, Parágrafo Único, limita o reconhecimento da propriedade somente às terras que "eram ocupadas por quilombos em 1888 e que estavam ocupadas por remanescentes das comunidades dos quilombos em 5 de outubro de 1988", sem conferir identidade étnica e territorialidade quilombola ao direito conferido pela Lei Maior.

Portanto, dois anos depois, já na gestão do Presidente Luís Ignácio Lula da Silva, o Decreto no 4.887, de 20 de novembro de 2003, revogou o decreto anterior, regulamentando o procedimento para identificação, reconhecimento, delimitação e titulação das terras de que trata o artigo 68 do ADCT. O conceito de território dos "remanescentes de quilombo" trazido pelo Decreto vigente considera as práticas de resistência, a territorialidade negra, gênero de vida e trajetória de grupo coletivo:

Art. 1

$\S 1 \underline{\text { o }}$ Para os fins deste Decreto, a caracterização dos remanescentes das comunidades dos quilombos será atestada mediante autodefinição da própria comunidade.

§ 20 São terras ocupadas por remanescentes das comunidades dos quilombos as utilizadas para a garantia de sua reprodução física, social, econômica e cultural.

§ 3o Para a medição e demarcação das terras, serão levados em consideração critérios de territorialidade indicados pelos remanescentes das comunidades dos quilombos, sendo facultado à comunidade interessada apresentar as peças técnicas para a instrução procedimental.

Art. 2o Consideram-se remanescentes das comunidades dos quilombos, para os fins deste Decreto, os grupos étnico-raciais, segundo critérios de autoatribuição, com trajetória histórica própria, dotados de relações territoriais específicas, com presunção de ancestralidade negra relacionada com a resistência à opressão histórica sofrida.

Importante observar que o Decreto de 2003 reconheceu o conceito de território usado. "Quando se fala em território deve-se, portanto, de logo, entender que se está falando em território usado, utilizado por uma dada população" (SANTOS, 2012b, p.96-97).

Enquanto o primeiro se limitava a considerar a situação passada de terras que "eram ocupadas por quilombos em 1888 e que estavam ocupadas por remanescentes das comunidades dos quilombos em 5 de outubro de 1988", o segundo Decreto considera o sentimento de pertencimento ao território da comunidade ao reconhecer o direito de autodefinição, além do uso feito por essa comunidade com o fim de garantir sua "reprodução física, social, econômica e cultural". Além disso, dialoga com o conceito de espaço social 
necessário à reprodução da vida: “[...] o espaço não pode ser apenas um reflexo do modo de produção atual porque é a memória dos modos de produção do passado”. (SANTOS, 2008, p. 181).

O Decreto no 4.887, ao considerar a "ancestralidade negra relacionada com a resistência à opressão histórica sofrida" propôs um conceito geográfico ao espaço dos quilombolas, pois o espaço no conceito de Milton Santos (2008, p. 153) "se define como um conjunto de formas representativas de relações sociais do passado e do presente [...]”.

Outra inovação pretendida pelo Decreto diz respeito à gestão administrativa dos procedimentos de emissão de título com a introdução da responsabilização do Instituto Nacional de Colonização e Reforma Agrária - INCRA, com histórica experiência em regularização fundiária, pela identificação, reconhecimento, delimitação, demarcação e titulação das terras.

O INCRA, assistido pela SEPPIR, que deve guardar os direitos étnicos e territoriais das comunidades quilombolas, e pela FCP, que deve garantir a preservação da identidade cultural dessas comunidades, pode dar início ao processo de ofício ou a pedido de qualquer interessado, sendo assegurado às comunidades participar em qualquer fase do procedimento administrativo.

Caso as comunidades estejam ocupando propriedades de domínio particular, o decreto prevê, também de forma inédita, a desapropriação por interesse social mediante indenização. Destaca-se ainda a possibilidade inserida de a titulação ser efetivada em nome da entidade representativa da comunidade. Arruti $(2009$, p. 85) destaca:

Este último aspecto é importante tanto por incorporar uma perspectiva comunitarista ao artigo constitucional (um direito de coletividades e não de indivíduos), quanto por dar à noção de "terra" a dimensão conceitual de território: nela se incluem não só a terra diretamente ocupada no momento específico da titulação, mas todos os espaços que fazem parte de seus usos, costumes e tradições e/ou que possuem os recursos ambientais necessários à sua manutenção e às reminiscências históricas que permitam perpetuar sua memória.

Contudo, vinte e quatro anos após o reconhecimento do direito territorial pela Constituição Federal e nove anos após o regulamentação da certificação e titulação das terras quilombolas, os avanços na conquista da propriedade definitiva de suas terras são retardados 
pelo longo caminho burocrático para a regularização fundiária quilombola. As etapas do processo são diversas, complexas e morosas.

Primeiramente, com a certificação da Fundação Cultural Palmares- FCP, abre-se processo, de ofício ou a requerimento por qualquer parte interessada, no INCRA. Então, uma equipe multidisciplinar daquele órgão produz o Relatório Técnico de Identificação Delimitação - RTID $^{3}$ com o fim de identificar e delimitar o território abordando informações cartográficas, fundiárias, agronômicas, ecológicas, geográficas, socioeconômicas, históricas e antropológicas, a serem obtidas por meio de trabalho em campo e por dados oficiais. Publicase então o RTID em uma portaria com abertura de prazo para eventuais contestações. Se aprovado, o INCRA emite portaria de reconhecimento do território quilombola. No caso de localização do território em terras públicas ou de domínio particular, passa-se pela etapa de desapropriação por interesse social. Somente após procedimentos de desintrusão do território, o título coletivo é emitido em nome das associações, que deverão registrar o território do serviço registral da comarca em que pertence.

O Relatório de Gestão do PBQ 2012 (BRASIL, 2013) apresentou que 2.040 comunidades foram certificadas pela Fundação Cultural Palmares até dezembro de 2012. Como representado no Gráfico 1, das 2.040 comunidades certificadas até então, 1.229 haviam aberto processos de regularização no INCRA até janeiro de 2012. Porém, até 2012, somente 207 comunidades tiveram a titulação da terra, regularizando 995.009,0875 hectares em 124 territórios. Nota-se que, este ínfimo número representa ainda um recente processo de

\footnotetext{
${ }^{3}$ É um relatório técnico produzido por uma equipe multidisciplinar do INCRA, criada por Ordem de Serviço. Sua finalidade é identificar e delimitar o território quilombola reivindicado pelos remanescentes das comunidades dos quilombos. O RTID aborda informações cartográficas, fundiárias, agronômicas, ecológicas, geográficas, socioeconômicas, históricas e antropológicas, obtidas em campo e junto a instituições públicas e privadas, sendo composto pelas seguintes peças: relatório antropológico; levantamento fundiário; planta e memorial descritivo do perímetro da área reivindicada pelas comunidades remanescentes de quilombo, bem como mapeamento e indicação dos imóveis e ocupações lindeiros de todo o seu entorno; cadastramento das famílias remanescentes de comunidades de quilombos; levantamento e especificação detalhada de situações em que as áreas pleiteadas estejam sobrepostas a unidades de conservação constituídas, a áreas de segurança nacional, a áreas de faixa de fronteira, terras indígenas ou situadas em terrenos de marinha, em outras terras públicas arrecadadas pelo INCRA ou Secretaria do Patrimônio da União e em terras dos estados e municípios; parecer conclusivo. Após a sua conclusão, o mesmo deve ser aprovado pelo Comitề de Decisão Regional - CDR e ser publicado na forma de Edital, por duas vezes consecutivas nos Diários Oficiais da União e do Estado, assim como afixado em mural da Prefeitura. Fonte: http://www.incra.gov.br/images/phocadownload/politica_fundiaria/Quilombolas/etapas/quadro_geral.p df , acesso em: 08 fev 2014)
} 
conquista do território quilombola, pois cerca de $70 \%$ dos títulos foram concedidos entre 2003 e 2012.

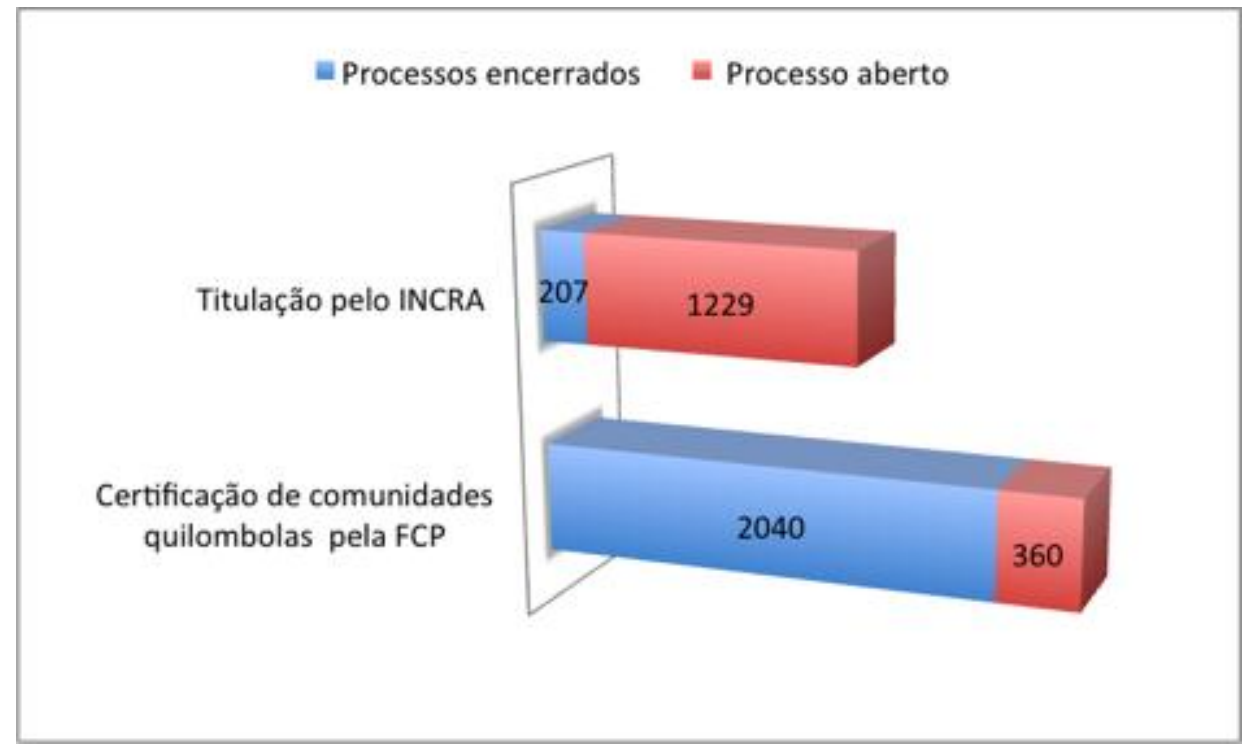

Gráfico 1- Regularização da terra quilombola. Fonte: Relatório de Gestão do PBQ 2012

Dados mais recentes da SEPPIR (Brasil, 2014) indicam que em novembro de 2014 havia $2.409^{4}$ comunidades certificadas, um aumento de quase 400 comunidades em um período de dois anos.

Conforme demonstrado no mapa a seguir (figura 2), os estados com número de territórios quilombolas titulados estão concentrados nas regiões Nordeste, em especial no Maranhão e Bahia, e Norte, sendo que o Pará concentra 23\% dos territórios quilombolas titulados, o que corresponde a 56 territórios conforme dados do Sistema de Monitoramento da SEPPIR. Os estados com menor número de territórios titulados é a Amazônia e Alagoas, com apenas um território titulado cada.

A presença de maior parte dos territórios titulados na região nordeste demonstra não só a presença concentrada de territórios quilombolas em estados com maior vulnerabilidade

\footnotetext{
${ }^{4}$ Esse número representa as comunidades certificadas e tituladas no país até novembro de 2014. Destaca-se que se somarmos 48 comunidades que foram tituladas sem a devida certificação por Institutos de Terra Estaduais, o número chega a 2.457 comunidades reconhecidas pelo Estado brasileiro. Os Institutos de Terra Estaduais podem realizar a titulação em terras devolutas estaduais e não estão submetidos ao regramento de titulação que pede a certificação pela FCP.
} 
social, mas também a prioridade que o Governo Federal tem dado desde 2003 para fomentar a região. A titulação dos territórios quilombolas sinaliza a intenção do Estado de incluir a população remanescente de quilombos nas políticas públicas, em especial as de educação, saúde, assistencial social, segurança alimentar e desenvolvimento agrário.

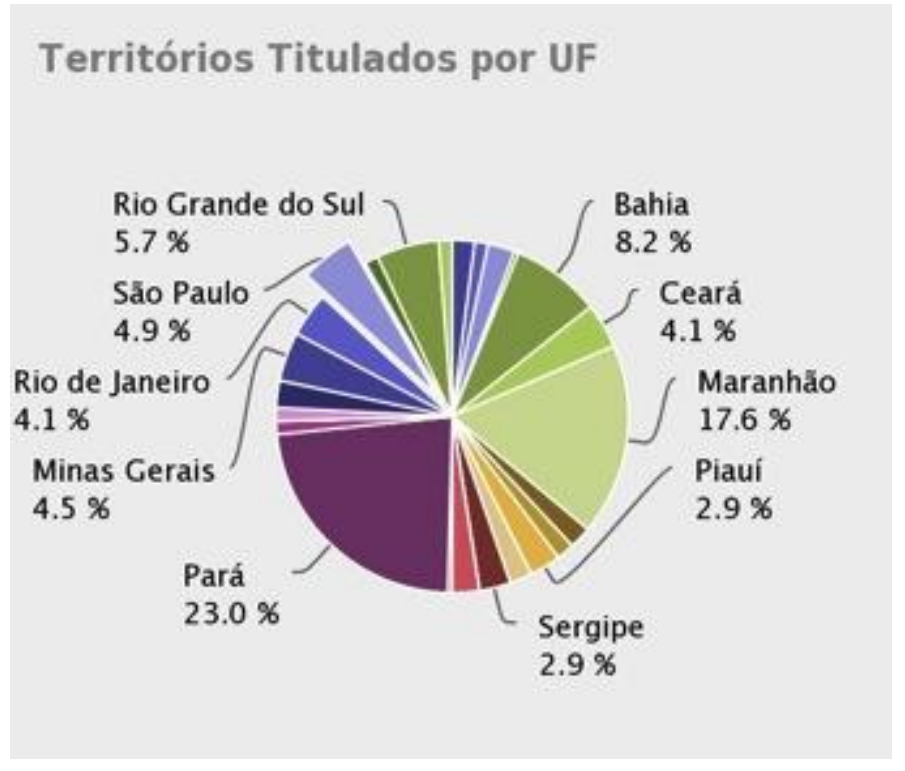

Figura 2: Concentração dos territórios quilombolas titulados. Fonte: Sistema de Monitoramento, SEPPIR, BRASIL, 2015

A titulação do território é considerada prioridade pelos remanescentes de quilombo, e as consequências do título da terra para acesso às políticas públicas e para fortalecimento de sua identidade quilombola, mesmo recente, é percebido pelas comunidades beneficiadas.

Pesquisa contratada pelo Programa das Nações Unidas para o Desenvolvimento -PNUD em parceria com o Ministério do Desenvolvimento Social e Combate à Fome- MDS, intitulada "Avaliação da Situação de Segurança Alimentar e Nutricional em Comunidades Quilombolas Tituladas (Censo)", realizada entre abril e setembro de 2011 pelo Núcleo de Pesquisas de Avaliação de Políticas Públicas da Universidade Federal Fluminense (DataUFF), mostra que, na opinião de $53 \%$ das lideranças quilombolas sobre a situação da comunidade após recebimento do título do território, o acesso da comunidade a políticas e programas públicos aumentou a titulação. 
Porém, em uma análise mais atenta, percebe-se que os desafios são maiores que os resultados positivos. Somente $37,3 \%$ relataram melhoria no acesso à infraestrutura de água e de esgoto, e $40 \%$ relataram melhoria na qualidade da alimentação.

Os pontos positivos da titulação estão relacionados ao fortalecimento da cidadania por meio de maior participação e mobilização política da comunidade, segundo mais de $60 \%$ dos entrevistados. Outra relevante variável diz respeito ao fortalecimento da identidade negra e quilombola de acordo com quase $80 \%$ dos entrevistados.

Para os Kalunga, o reconhecimento da comunidade pelo Estado foi um grande marco na sua luta. O reconhecimento de seu território representa o reconhecimento de sua história de vida, de sua identidade de luta e de pertencimento àquele lugar. Seu Sirilo, homem de grande relevância na luta dos Kalunga, tendo sido a liderança da comunidade por mais de 12 anos, entende que os Kalunga passaram a ter voz junto aos governos e a serem vistos como sujeitos de direitos.

O território Kalunga (mapa- figura 3) foi reconhecido como Sítio Histórico e Patrimônio Cultural Kalunga por meio das Leis Estadual n 11.409, de 21 de janeiro de 1991 e Complementar do Estado de Goiás nº 19, de 5 de janeiro de 1996, com 253,2 mil hectares de terras. Em 2009, decreto da Presidência da República aumentou o território Kalunga para 261,9 mil hectares de área nos três municípios, reforçando o reconhecimento como comunidade quilombola, que já havia sido emitido pela FCP. 


\section{SITIO HISTÓRICO E CULTURAL DO REMANESCENTE DE QUILOMBO KALUNGA - GO. -MAPA GERAL DAS LOCALIDADES .}
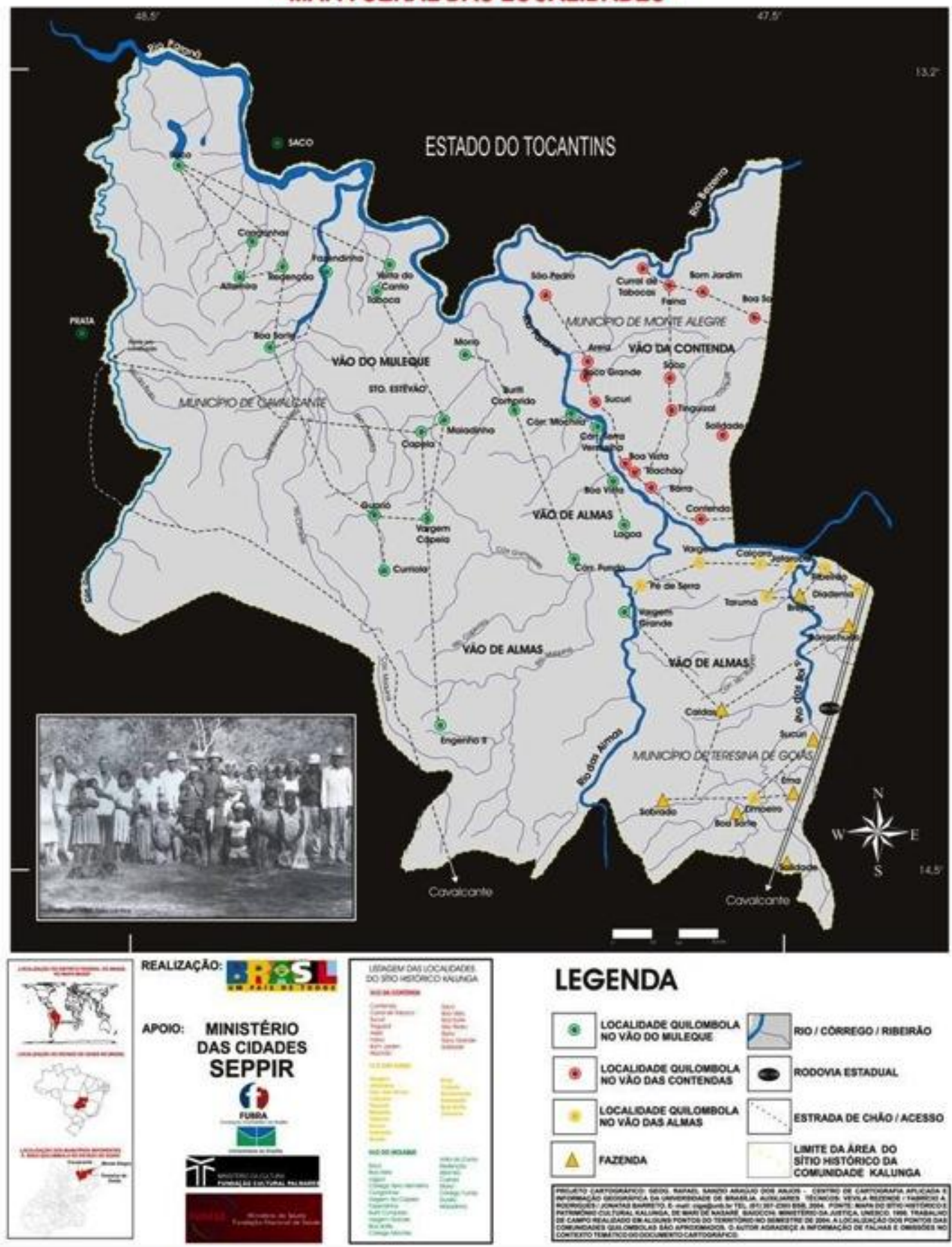

LEGENDA

\begin{tabular}{|c|c|c|}
\hline $\boldsymbol{\theta}$ & 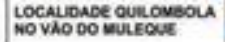 & Fo / COESROO / RiBcipho \\
\hline (3) & 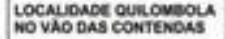 & ROOONa ESTRDUAL \\
\hline$*$ & 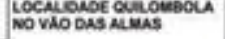 & Esso \\
\hline$\Delta$ & Farevion & 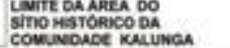 \\
\hline
\end{tabular}

Figura 3- Localidades quilombolas e fazendas no sítio histórico e cultural da comunidade Kalunga. Autoria: Rafael. S.A dos Anjos. Centro de Cartografia Aplicada e Informação Geográfica. UNB. S.d.

O mapa da Cartografia Aplicada e Informação Geográfica da UNB (figura 3) mostra sua grande extensão territorial, em especial no município de Cavalcante, onde está localizada a 
maior parte das localidades Kalunga, sendo o Vão do Moleque e o Vão de Almas as de maior extensão e população, embora esta esteja distribuída esparsamente. Os municípios de Teresina de Goiás e Monte Alegre têm como localidades mais populosas a Ema e o Riachão no Vão da Contenda, respectivamente.

Segundo dados do sítio eletrônico do INCRA $^{5}$, a certificação e a titulação desse território foram concedidas em 2000 pela FCP, porém sem proceder à desintrusão do território. Para recebimento do documento de propriedade definitiva e seu registro em cartório, os Kalunga aguardam os procedimentos de desapropriação de terras em posse de fazendeiros e grileiros localizados em sua área de abrangência.

$\mathrm{Na}$ tentativa de apoiar a desintrusão das terras dentro do território Kalunga ocupada por fazendeiros e grileiros, a Presidência da República reconheceu o território do quilombo Kalunga como de interesse social para fins de desapropriação de todos os imóveis situados dentro de seu perímetro nos municípios de Cavalcante, Teresina de Goiás e Monte Alegre por meio de decreto presidencial em 20 de novembro de 2009, mencionado acima.

No entanto, o processo de desapropriação tem sido lento e marcado pela luta das organizações locais da Comunidade juntamente com a Coordenação Nacional de Articulação das Comunidades Negras Rurais Quilombolas - CONAQ a fim de completar o processo de desapropriação e indenização, retardado pelo grande número de processos judiciais por parte dos posseiros.

O quilombo Kalunga está inserido em uma região de dominação de grileiros e fazendeiros que comumente detêm o poder político por meio de cargos públicos eletivos. A força de autoridades locais não favorece, nesse sentido, a luta dos Kalunga pelo seu direito constitucional. "Como resolver a questão de dentro de um mesmo país, quando o passado não ofereceu como herança conjunta a existência de culturas particulares solidamente estabelecidas, junto a uma vontade política regional já exercida como poder?” (SANTOS, 2012b, p.87).

\footnotetext{
${ }^{5}$ Fonte: http://www.incra.gov.br/images/phocadownload/politica_fundiaria/Quilombolas/etapas/titulos_expedid os28.01.pdf
} 
Aos "macroatores", que, segundo Santos (2012b, p. 106), são "aqueles que de fora da área determinam as modalidades internas de ação", nesse caso o Governo Federal, cabe a tarefa de melhor regulamentar e organizar os processos burocráticos de desintrusão e titulação dos territórios quilombolas. A regulamentação vigente não parece ser eficaz na medida que impõe certificados complexos envolvendo conhecimentos múltiplos e procedimentos que favorecem a descontinuidade do processo regulatório e a prevalência dos interesses particulares aos interesses públicos.

É no lugar, "considerado como espaço de exercício da existência plena" (SANTOS, 2012b, p. 114), que as pessoas criam o conflito para buscar a sobrevivência à sua maneira, exigindo a mediação política, jurídica e técnica. "Mediação jurídica e mediação técnica se completam. O espaço, por seu conteúdo técnico, é regulador, mas um regulador regulado, já que as normas administrativas [...] determinam os comportamentos" (SANTOS, 2006, p. 230).

O papel do Estado aparece assim como determinante para identificar as forças locais e o conteúdo técnico da área que acaba por influenciar o comportamento dos agentes, a fim de estabelecer normas que venham integrar o espaço e estruturar a realidade.

Cabe ao Estado brasileiro, reconhecendo a territorialidade quilombola, a ação mediadora que garanta a prevalência dos interesses públicos sobre os corporativos. Santos (2014) faz a distinção entre território e territorialidade, sendo aquele o "espaço apropriado e usado" e esta o sentido de "pertencer àquilo que nos pertence". Assim, a territorialidade dos Kalunga, que pertencem àquele território tanto quanto ele os pertence, é a base para sua percepção como sujeitos de direito, enquanto o território é a base para legitimar a identidade e a força quilombola e para o Estado implementar políticas públicas.

A histórica busca dos remanescentes de quilombos pelos seus direitos territoriais permite que se invoque Santos (2012b) e Sen (2010) como base teórica para considerações a respeito da formação espacial, território e desenvolvimento humano. Em Por uma outra Globalização, Milton Santos (2012b, p. 62) explicita a centralidade do território:

Nesse começo dos tempos, os laços entre território, política, economia, cultura e linguagem eram transparentes. [...] A economia e a cultura dependiam do território, a linguagem era uma emanação do uso do território pela economia e pela cultura... em todas as manifestações essenciais de sua 
existência, os moradores pertenciam àquilo que lhes pertencia, isto é, o território.

O sentimento de pertencimento ao território justificado pelo laço de identidade econômica, cultural e política dos quilombolas com as terras em que se situam é o grande definidor de sua condição e percepção de liberdade e gozo de vida digna. Nas palavras de Sen (2010, p. 28-29):

Uma concepção adequada de desenvolvimento deve ir muito além da acumulação de riqueza e do crescimento do Produto Nacional Bruto e outras variáveis relacionadas à renda. Sem desconsiderar a importância do crescimento econômico, precisamos enxergar muito além dele. [...]. O desenvolvimento tem de estar relacionado sobretudo com a melhora da vida que levamos e das liberdades que desfrutamos. Expandir as liberdades que temos razão para valorizar não só torna a nossa vida mais rica e mais desimpedida, mas também permite que sejamos seres sociais mais completos, pondo em prática nossas volições, interagindo com o mundo em que vivemos e influenciando esse mundo.

A relato das lideranças quilombolas quanto à importância da conquista efetiva de seu território para acesso ao Estado e para inserção digna na vida pública mostra que eles almejam o desenvolvimento como forma de melhorar a qualidade de vida de todos os moradores da comunidade. Cientes de sua territorialidade, os quilombolas lutam para invocar seus direitos junto ao poder público para usar de fato o território para as manifestações da vida social.

O território não é apenas o resultado da superposição de um conjunto de sistemas naturais e conjunto de sistemas de coisas criadas pelo homem. $\mathrm{O}$ território é o chão e mais a população, isto é, uma identidade, o fato e o sentimento de pertencer àquilo que nos pertence. O território é a base do trabalho, da residência, das trocas materiais e espirituais e da vida, sobre os quais ele flui. Quando se fala em território deve-se, pois, de logo, entender que se está falando em território usado, utilizado por uma dada população. (SANTOS, 2012b, p. 96-97). 


\subsection{O MODO DE VIVER KALUNGA}

Paralelamente ao direito territorial constitucional e à luta pelo título da terra, "a identidade cultural Kalunga vai dar sentido ao território e definir as territorialidades. A territorialidade define uma relação individual ou coletiva ao território e se apoia sobre as paisagens" (ALMEIDA, 2010, p.45).

O Sítio Histórico e Patrimônio Cultural Kalunga está localizado na microrregião da Chapada dos Veadeiros, marcada pela exuberância de sua formação vegetal de cerrado (figura 4), cânions, chapadões, rios e cachoeiras.

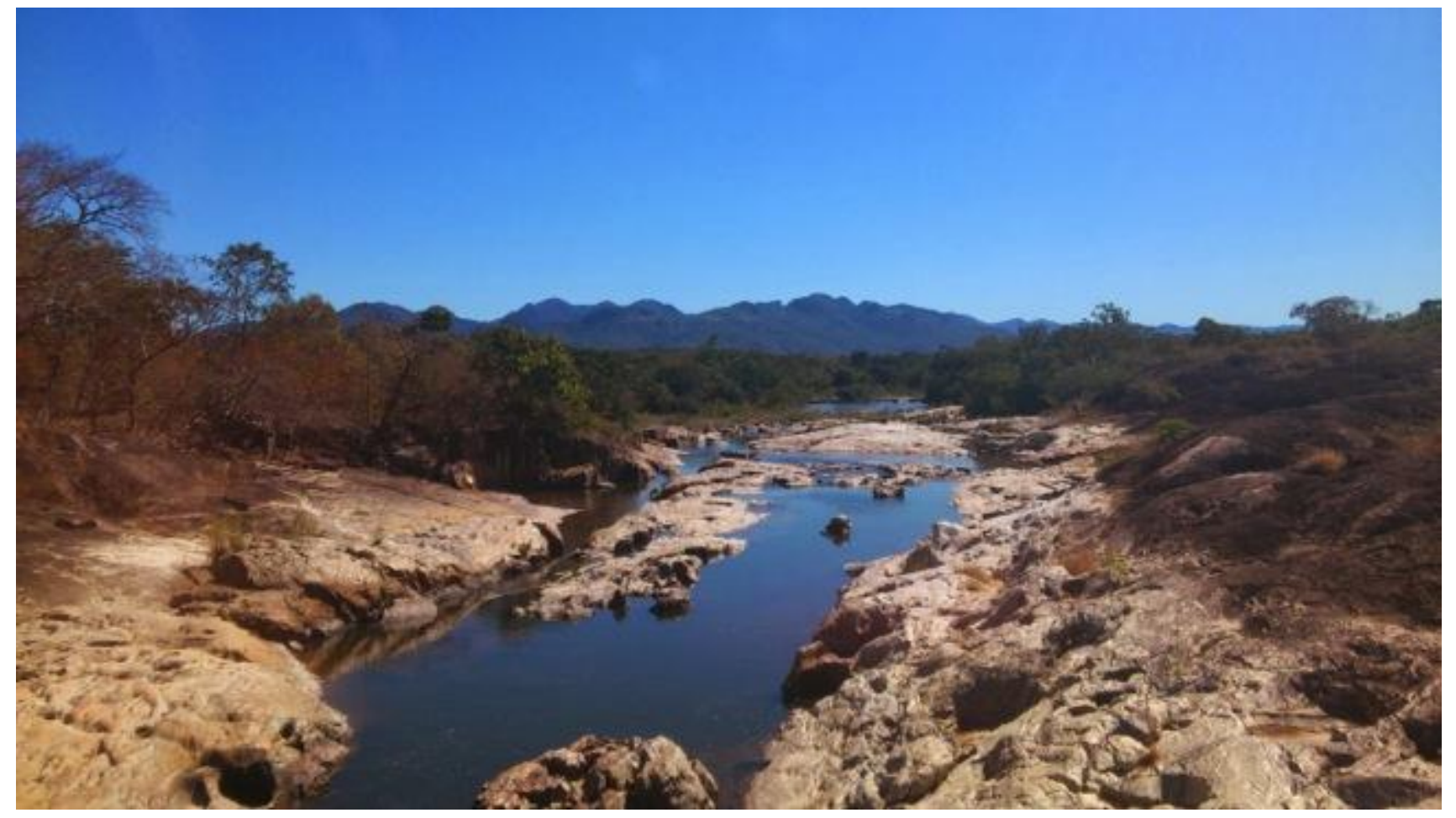

Figura 4 - Formação vegetal de cerrado e chapadões. Fonte: A autora, junho 2013

Devido à sua biodiversidade, a Chapada possui também o título de Reserva da Biosfera de Goyas, abrigando o Parque Nacional da Chapada dos Veadeiros, reconhecido pela UNESCO como patrimônio natural mundial. 
Além das paisagens, o território Kalunga ${ }^{6}$ também é marcado pelos saberes e tradições de um povo isolado geograficamente e socialmente dos espaços geopolíticos dos municípios. Com pouco acesso a bens e serviços públicos, eles viveram e vivem em uma relação simbiótica com a natureza, preservando a vegetação nativa do cerrado e seus recursos naturais

[...] a terra de cultivo e morada se opõe às relações de mercado enquanto estrutura básica, oferecendo resistência à lógica capitalista da acumulação. Tal aspecto não significa que, enquanto unidade de produção/consumo, esteja alheia às trocas mercantis, mas que as desenvolve a partir das necessidades e perspectivas do grupo doméstico. (OLIVEIRA, 2001, p. 256)

Tendo o Rio Paranã como o símbolo da força que os protegia da escravidão e os permitia plantar e símbolo da união e solidariedade de todos em torno de um rio, o povo Kalunga foi fazendo seu modo de vida dividido entre o tempo das chuvas e o tempo da seca.

Aprenderam a regular o plantio das roças nas poucas terras férteis à beira do Rio Paranã e seus afluentes, que, nas enchentes, inundavam as terras adubando e preparando para o plantio. O conhecimento do cerrado torna-se o marco do modo de vida Kalunga, que retribui com a preservação da natureza.

A paisagem, que nos permite uma visão parcial, é formada por velhos objetos geográficos - são as casas de farinha, as roças à beira dos rios, as galinhas soltas no quintal das casas de adobe e palha, as serras densas de vegetação nativa - que se juntam a novas técnicas e símbolos de desenvolvimento- casas de alvenaria em algumas localidades, escolas, placa solar, antena de celular, entre outros.

O advento de políticas públicas somente para algumas localidades trouxe desigualdade dentro do território Kalunga. A paisagem no povoado Kalunga Engenho II, dentro do município de Cavalcante, assemelha-se a paisagem do povoado da Ema, dentro de Teresina de Goiás, e ambas contrastam imensamente com a paisagem do Vão do Moleque e do Vão de Almas. Nas duas primeiras, a paisagem traz elementos de transformação espacial recente:

${ }^{6}$ Dividido em cinco grandes núcleos: Contenda, Kalunga, Vão de Almas, Vão do Moleque e Ribeirão dos Bois. Estes subdividem-se em dezenas de agrupamentos ou povoados, como: Contenda, Barra, Riachão, Sucuriú, Curral de Taboca, Saco Grande, Ema, Diadema, Engenho II, entre tantos outros 
postes de luz, telefone público, caixas d'água em cima das casas, casas de farinha coletivas construídas com alvenaria e equipadas, casas de alvenaria e telhado de cerâmica.

Como as figuras 5, 6, 7 e 8 mostram, o espaço é formado por ações estatais que beneficiaram a comunidade no sentido de incluí-las no processo de desenvolvimento. $\mathrm{O}$ Engenho II, em especial, conta com a presença de energia elétrica, telefone público, escolas de ensino fundamental e médio, posto de saúde, restaurantes e Centro de Atendimento ao Turista. A configuração territorial do povoado do Engenho II expressa o espaço transformado pela ação governamental, que juntou-se aos objetos existentes, transformando as possibilidades futuras da comunidade.

Santos (2014, p. 72-73) fala sobre a transformação da paisagem em Metamorfose do Espaço Habitado:

\footnotetext{
A paisagem não se cria de uma só vez, mas por acréscimos, substituições; a lógica pela qual se fez um objeto no passado era a lógica da produção daquele momento. Uma paisagem é uma escrita sobre a outra, é um conjunto de objetos que tem idades diferentes, é uma herança de muitos momentos.
}

A herança dos ancestrais Kalunga continua presente na comunidade do Engenho II por meio dos elementos naturais da paisagem, das manifestações culturais e do seu modo de vida, mas não se pode negar que a nova configuração territorial desse povoado traz novas maneiras de se fazer, de trabalhar, de produzir, que os permitiram sair de um período lento para um período mais rápido, cuja tendência é colocar a paisagem cada vez mais em movimento, por meio de novas inserções e substituições, dado o alcance das técnicas.

As figuras 5 a 8 mostram novas formas inseridas no Engenho II que favorecem a produção (figura 5), o desenvolvimento humano (figura 6), a comunicação (figura 7), e a geração de renda (figura 8). 


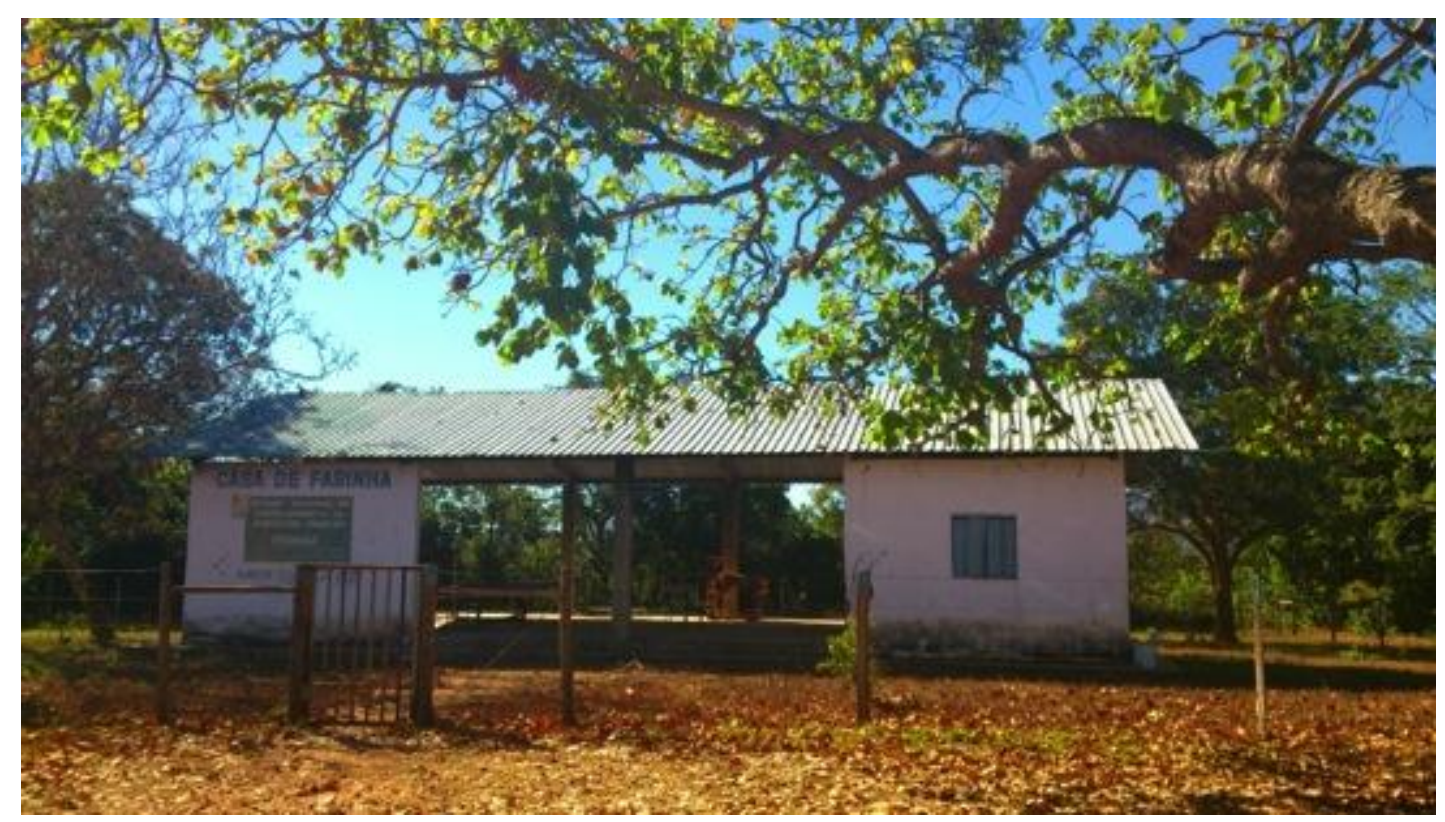

Figura 5- Casa de Farinha no povoado da Ema. Fonte: A autora, junho 2013

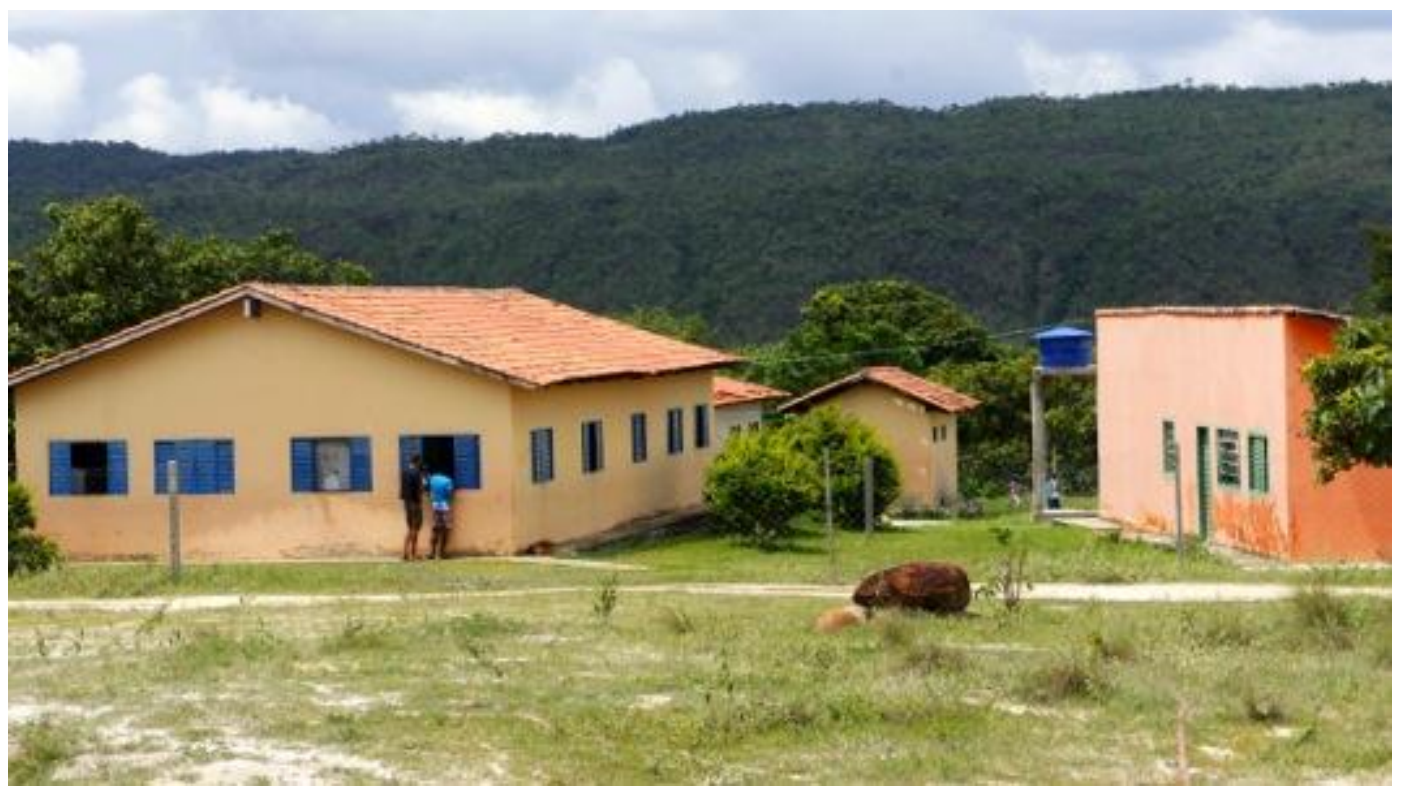

Figura 6- Escola estadual na Comunidade Engenho II. Fonte: A autora, fevereiro, 2015 


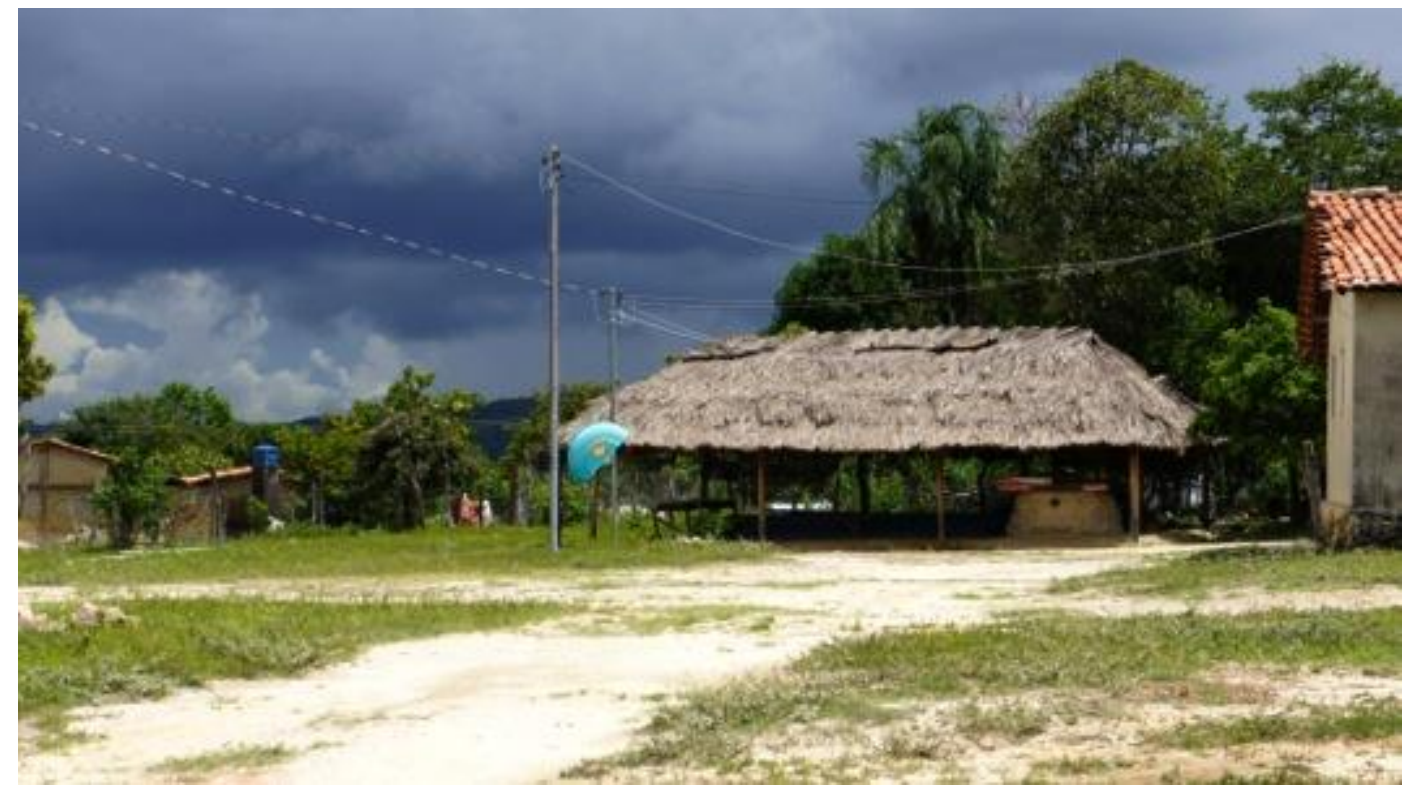

Figura 7- Povoado do Engenho II. Fonte: A autora, fevereiro, 2015.

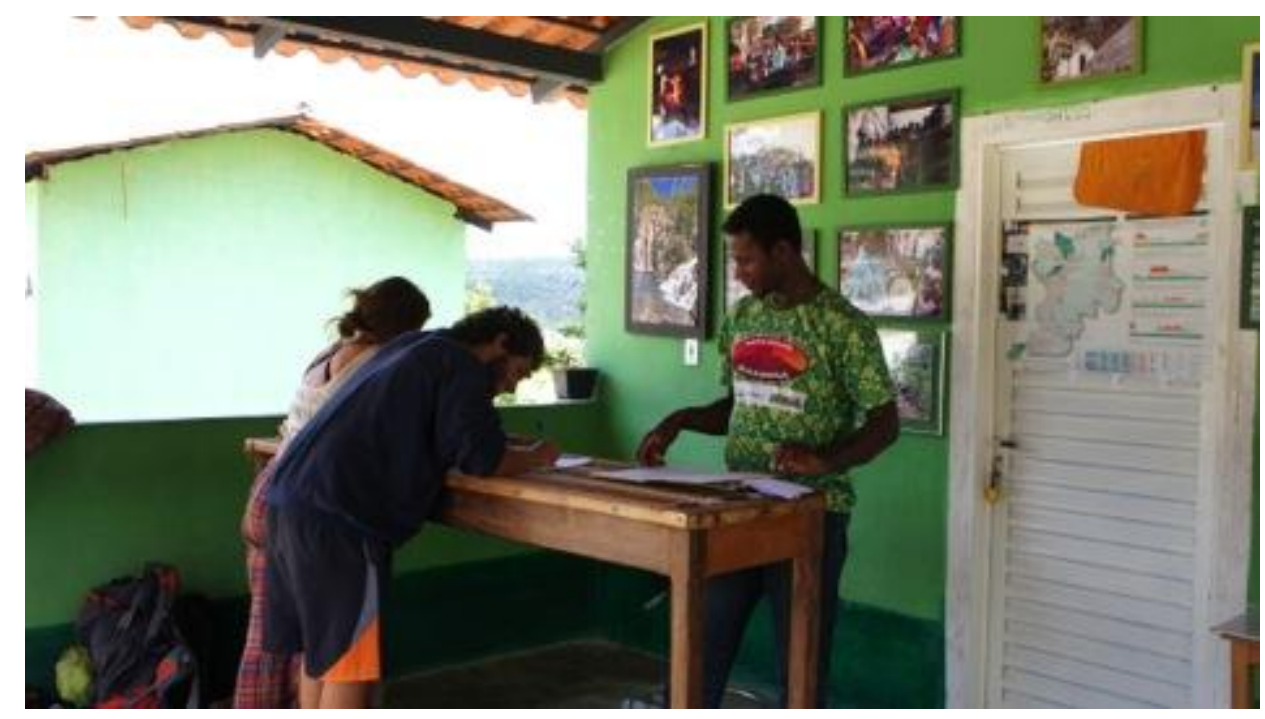

Figura 8- Centro de Atendimento ao Turista no Engenho II. Fonte: A autora, fevereiro, 2015.

Já o Vão de Almas e o Vão do Moleque, ambas localidades no município de Cavalcante, objetos naturais ainda persistem majoritariamente juntamente a elementos artificiais antigos e novos: rios e canoas (figura 9), serras e cachoeiras ao longe (figura 10), estradas precárias, , casas de adobe e palha (figura 11) e uma ou outra antena de celular ou placa solar que gere energia para a bomba de água do rio. 


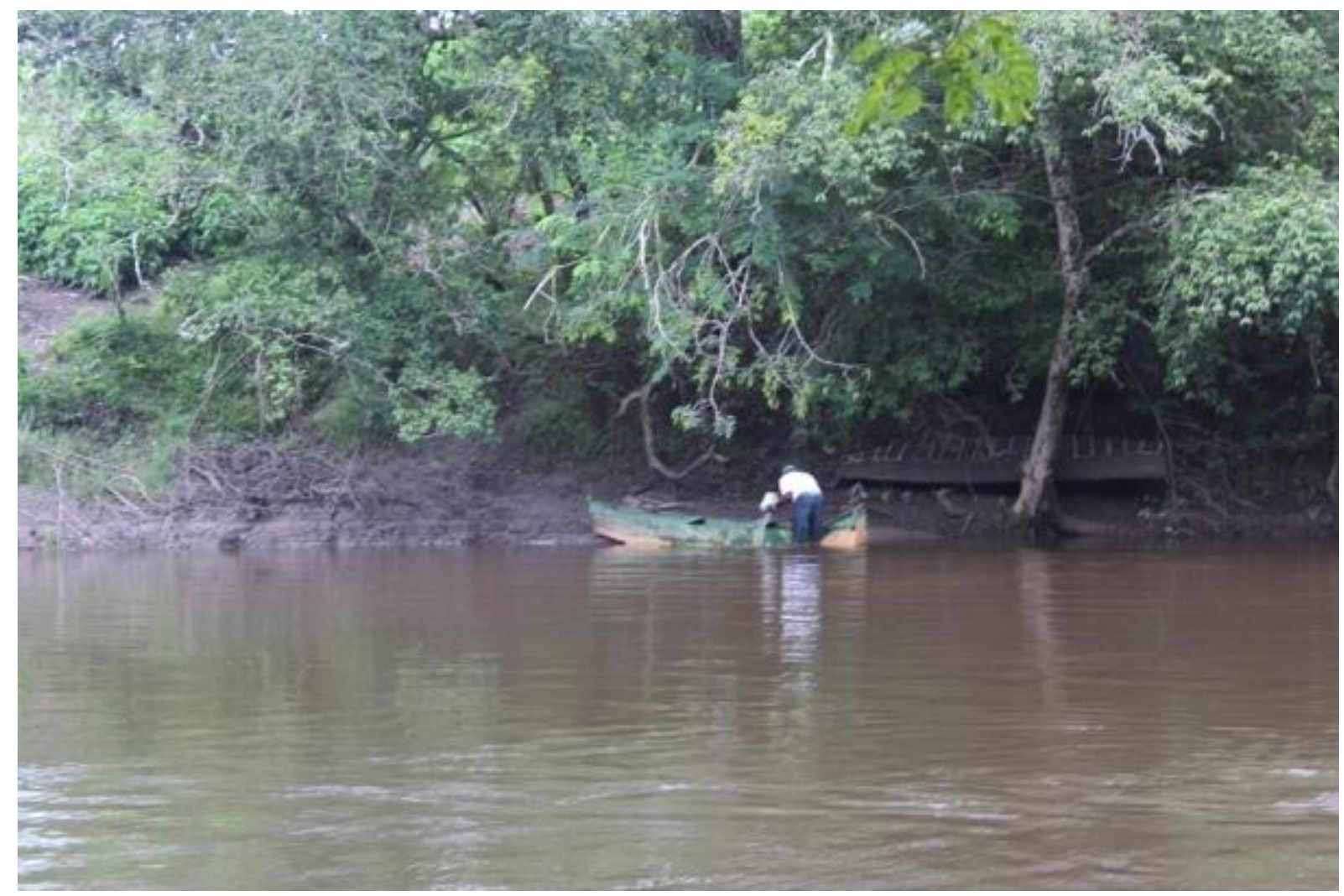

Figura 9- Vão de Almas: travessia de canoa no Rio das Almas. Fonte: A autora, março, 2015

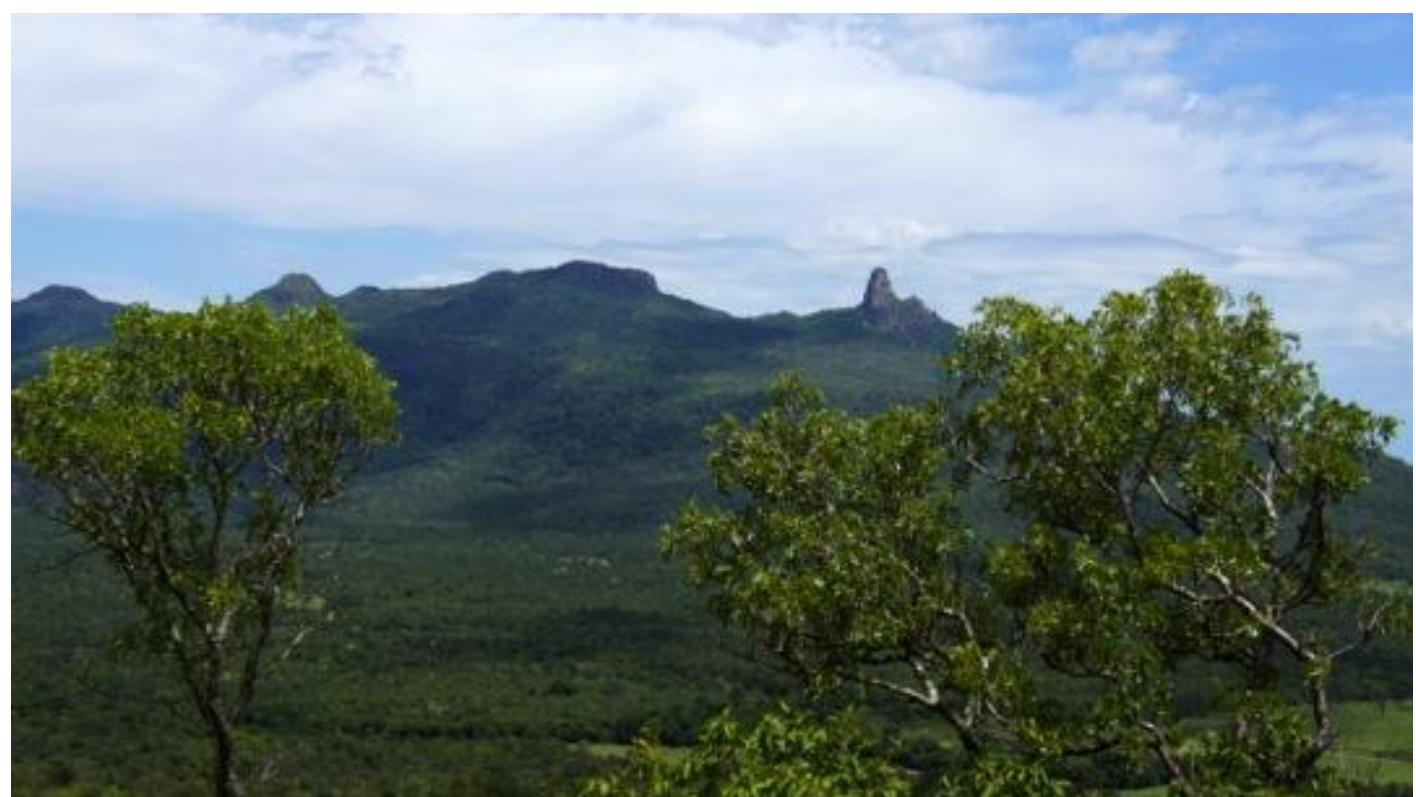

Figura 10- Imensidão do verde do Vão do Moleque. Fonte: A autora, fevereiro, 2015. 


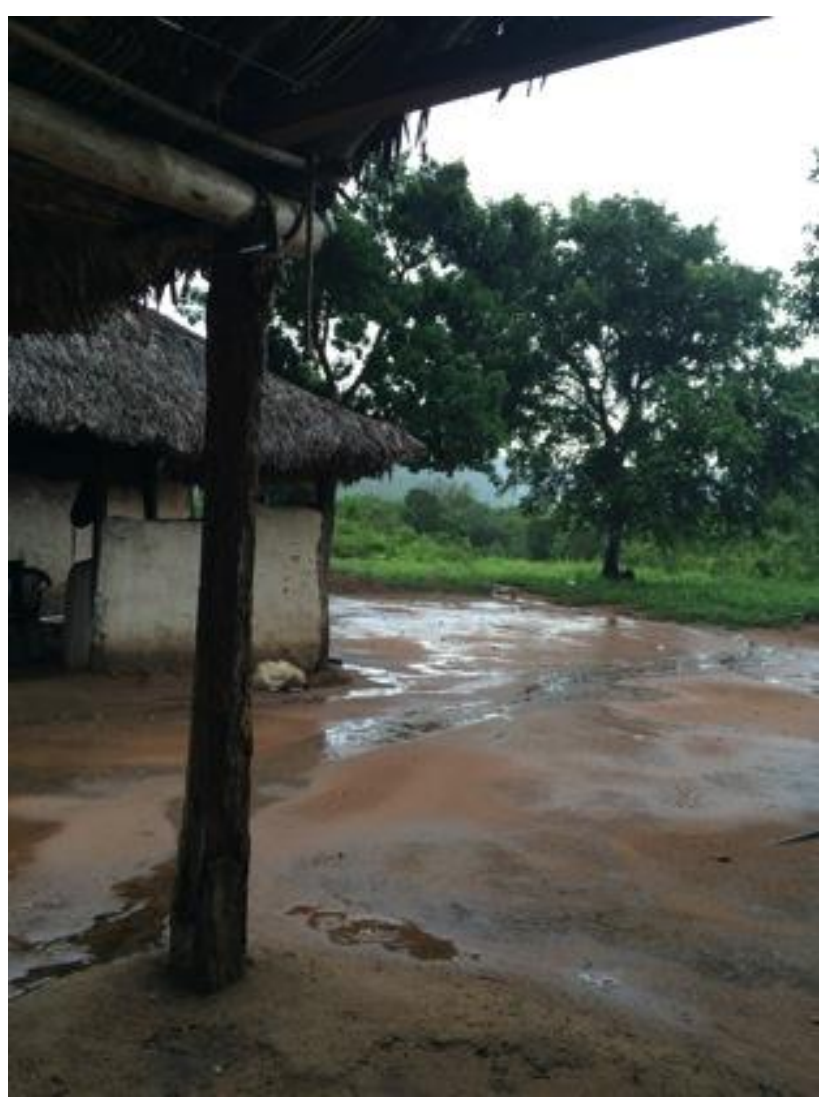

Figura 11- Vão de Almas: Casa de adobe e palha. Fonte: A autora, março, 2015.

O envelhecimento das formas no Vão do Moleque e no Vão de Almas são visíveis, e a população Kalunga ali presente sente a necessidade de novas formas que possam lhes possibilitar o acesso a novas funções, e um espaço que permita aumentar suas capacidades de produção, de gerar renda e melhorar as condições de vida de suas famílias. Apesar das formas antigas, os Kalunga do Vão do Moleque e do Vão de Almas têm mudado seu modo de viver e seu espaço com sua vontade de desenvolver. Santos (2014, p. 85) afirma que "Podem as formas, durante muito tempo, permanecer as mesmas, mas, como a sociedade está sempre em movimento, a mesma paisagem, a mesma configuração territorial oferecem-nos, no transcurso histórico, espaços diferentes".

A produção de farinha e sua comercialização nas cidades do entorno foram durante muito tempo o principal meio de subsistência dos Kalunga. Durante anos a fio, a maior parte do alimento era proveniente da agricultura de subsistência- arroz, feijão, mandioca, milho, abóbora, cana, da criação de galinhas e porcos e da pesca. Porém, na época da seca, esses 
alimentos não eram de fácil acesso, sendo o arroz, o feijão, e a farinha estocados, a única fonte alimentícia. Em alguns casos, somente a farinha.

Hoje, com o acesso a benefícios socioassistenciais, como aposentadoria rural, benefício de prestação de continuada-BPC e Bolsa Família, muitos compram boa parte do alimento não produzido no comércio local das sedes dos municípios, em especial na época da seca. $\mathrm{O}$ recurso também é utilizado para investimento na produção por meio da compra de sementes, de insumos agrícolas e agropecuários. $\mathrm{O}$ recurso garantido mensalmente também permite que eles invistam na compra de antena de celular, de placa de geração de energia solar, de bombas de água, e até mesmo de tijolos e telhas para melhorias habitacionais.

Os moradores de Engenho II, onde há melhor infraestrutura para produção, trabalham com o turismo, como guia, prestando serviço de alimentação e vendendo artesanato. Outros trabalham nas fazendas próximas ou em casas na cidade sede do munícipio como empregadas domésticas ou peões de roça.

Grande parte dos Kalunga, no entanto, sobrevive predominantemente da produção familiar descapitalizada para o auto consumo, em pequena escala, de insumos agropecuários, com comercialização esporádica, sem iniciativa de produção coletiva ou associativa.

Os povoados Kalunga são lugares típicos de área rural do nordeste goiano, onde a pobreza prevalece, e há carência de vários tipos de consumo. Consumo este não permitido até mesmo pela falta de infraestrutura básica localmente.

A maior parte depende do caminhão "pau de arara" para se deslocar para cidade, por não possuir meio de transporte próprio. Possuir um carro implica maior custo para os Kalunga uma vez que, devido à precariedade das estradas e a ausência de pontes, é necessário que o carro tenha potência e tração nas quatro rodas. Ainda, os moradores do Vão do Moleque e do Vão de Almas, mesmo que tivessem condições financeiras, não podem comprar qualquer eletrodoméstico que aumente sua qualidade de vida, como a geladeira, por falta de energia elétrica nessas localidades. 
A partir do "reconhecimento de que cada lugar é teatro de tempos 'externos' múltiplos" (SANTOS, 2006, p.139), o tempo interno Kalunga choca-se com os tempos nacionais e globais de alta tecnologia informacional.

O lugar Kalunga pode ser traduzido conforme Santos (2006, p.327-328). descreveu saudosamente, em A Natureza do Espaço, ao referir-se aos intensos movimentos migratórios:

O sujeito no lugar estava submetido a uma convivência longa e repetitiva com os mesmos objetos, os mesmos trajetos, as mesmas imagens, de cuja construção participava: uma familiaridade que era fruto de uma história própria, da sociedade local e do lugar, onde cada indivíduo era ativo.

O lugar e o cotidiano Kalunga, em especial no Vão do Moleque e no Vão de Almas, são marcados fortemente pelo trabalho familiar nas roças, pela cozinha no fogão de lenha, pela busca da água nos rios, pela lavagem de roupa e louças nos rios (figura 12), pelos longos trajetos a pé para chegar à escola, pela pesca nos rios, e pelos rituais e festas religiosas e folias, as quais constituem o principal entretenimento dos povoados, que migram de acordo com o calendário das festas.

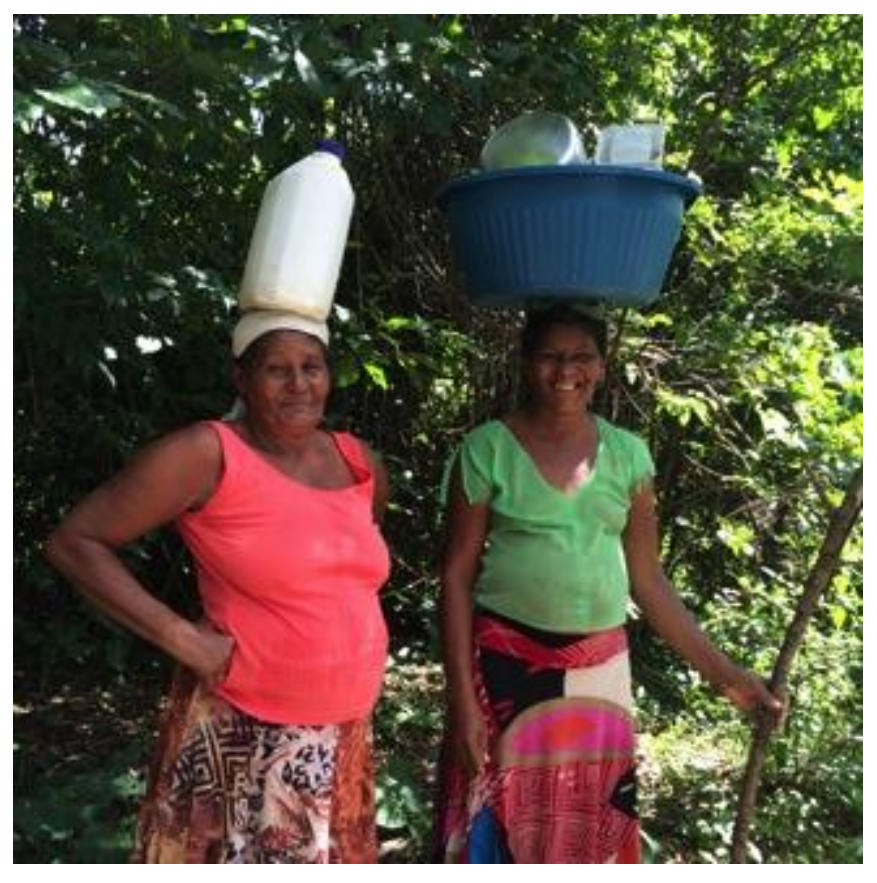

Figura 12- Mulheres Kalunga voltando do rio com as louças lavadas e a água para consumo na cabeça. Fonte: A autora, fevereiro, 2015. 
Durante o período das festas, os Kalunga têm a oportunidade de frequentar a missa, batizarem seus filhos e casarem-se com a benção do Padre, pois somente nessa época as capelas (figura 13) estão abertas com um celebrante. Por cerca de cinco a sete dias, os Kalunga migram e acampam com suas famílias nos festejos (figura 14) pelo tempo que dura a festa.

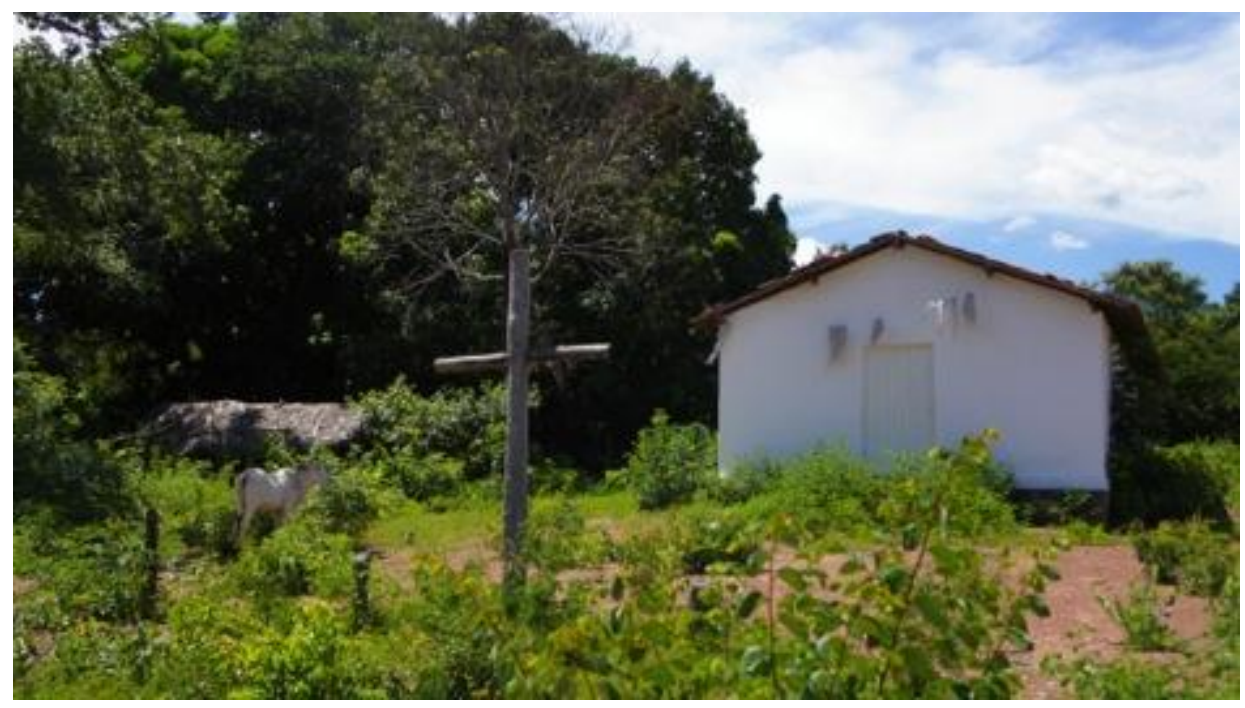

Figura 13- Capela do Vão do Moleque, fechada durante o ano inteiro. Abre somente na festa, quando o padre celebra a missa. Fonte: A autora, fevereiro, 2015

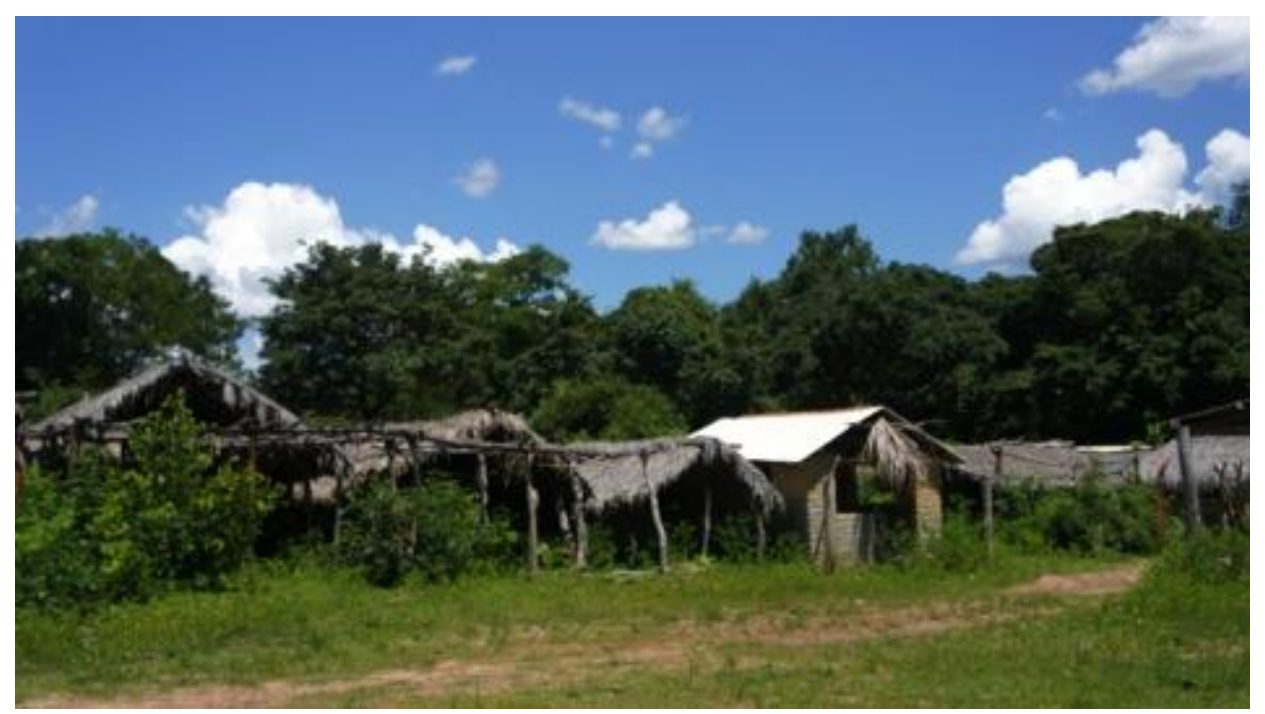

Figura 14- Local do festejo no Vão do Moleque. Aqui as barracas que os moradores acampam por dias enquanto duram as festas. Fonte: A autora, fevereiro, 2015. 
As folias ${ }^{7}$ e os "giros" são acompanhados de cantigas próprias, danças típicas dos Kalunga, como a curraleira - para o homens -, e a sussa, além de símbolos sagrados, como imagens de santos e mastros, regados a bebida e comida.

Cada qual com suas especificidades, as festas (figura 14) e folias ocorrem em pátios abertos constituídos de ranchos, que servem de hospedagem dos romeiros.

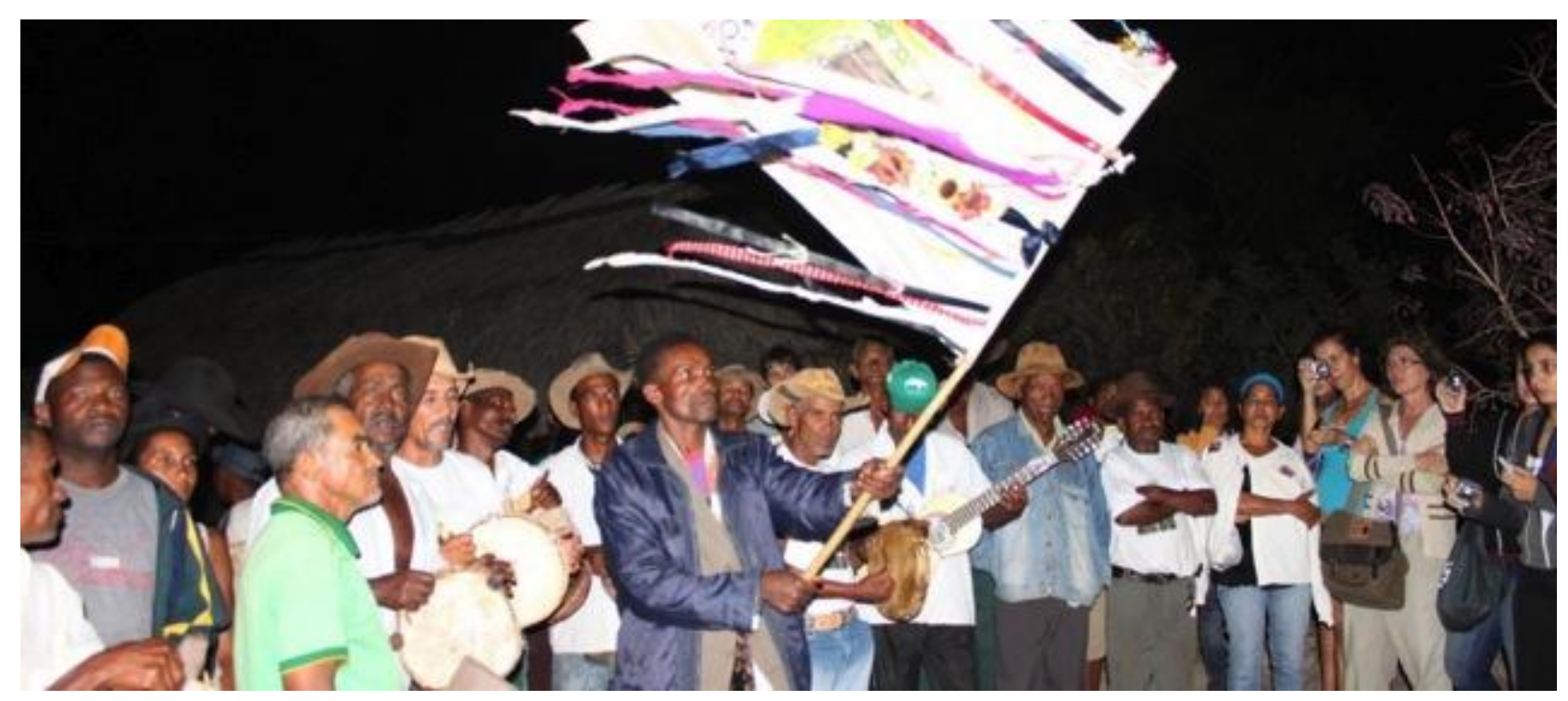

Figura 15- Engenho II: Festa de Santo Antônio. Fonte: http://www.novaorigem.com.br, acesso em: 22 fev. 2014

Interessante destacar que a religiosidade Kalunga acontece entre o divino e o homem. A pouca presença da igreja católica no território permite que os Kalunga criem maneiras próprias de expressar sua religiosidade. Por meio de suas crenças é que o social se realiza: batizados, casamentos, festas religiosas, novenas, entre outros.

Como as paisagens do cotidiano e das festas contribuem para a construção do lugar Kalunga? Apoiando-se na Geografia Cultural, compreende-se que "a identidade coletiva se exprime por símbolos capazes de tornarem sensíveis os valores compartilhados" (CLAVAL, 1999, p.157). Segundo Claval (1999, p.158), há sociedades “a tal ponto ligadas a seu território que não dispõem de outros símbolos para pensar a si próprias", a não ser o território.

\footnotetext{
${ }^{7}$ As folias acontecem antes das festas e as romarias com o objetivo de arrecadar doações em dinheiro ou alimento para as festas, além de anunciar sua realização.
} 
O Kalunga vê o lugar como uma extensão de si mesmo. "Bom ficar é no lugar onde a gente nasceu e criou e conhece" (Dona Getúlia, Engenho II). É o seu território que o permite ter liberdade de ser e existir. É no seu lugar que ele tem a memória viva de seus ancestrais, que ele sabe por que as glebas de terra estão divididas entre as famílias como estão, que ele entende as relações familiares entre tantos "Santos Rosa", "Moreira da Silva", entre outros.

O lugar Kalunga expressa os momentos vividos, as experiências; sendo dotado de valor e significado pelo homem que o habita. A lógica interna da comunidade é entendida por todos, pois é vivida no cotidiano por todos os membros da família, sem muita necessidade de explicação. O conhecimento cultural e a tradição social, pautadas no conhecimento popular, são transmitidos por meio da oralidade. Assim, o Kalunga, por meio das expressões de fé e trajetória de trabalho árduo na roça, transforma a paisagem do lugar com atribuição de valor, sentido e significado.

As normas informais do lugar são o traço de união entre todos os povoados dentro do território Kalunga. Santos (2006, p. 339) afirma que "cada lugar é, ao mesmo tempo, objeto de uma razão global e de uma razão local, convivendo dialeticamente".

A identidade da comunidade Kalunga destaca-se por ainda preservar costumes que já foram comuns em grande parte do território rural brasileiro, a despeito do mundo globalizado do século XXI. "O Sitio das Terras dos Kalunga constitui um legado cultural pela sua história e todo o conjunto de elementos simbólicos que ajudam a configurar a identidade cultural dos quilombolas naquele território no qual se acham legitimados socialmente." (ALMEIDA, 2010, p. 46)

A identidade Kalunga, ao mesmo tempo, é também a de uma comunidade pobre, sem grandes possibilidade de renda por meio do trabalho formal, com pouco acesso a direitos sociais, como educação, saúde, alimentação adequada e saudável, e com habitações precárias, entre outros indicadores de vulnerabilidade. Bauman (2005, p. 82) apresenta o paradoxo da identidade:

[...] a "identidade" é uma ideia inescapavelmente ambígua, uma faca de dois gumes. Pode ser um grito de guerra de indivíduos ou das comunidades que desejam ser por estes imaginadas. Num momento o gume da identidade é utilizado contra as "pressões coletivas" por indivíduos que se ressentem da conformidade e se apegam a suas próprias crenças [...] Em outro momento é 
o grupo que volta o gume contra um grupo maior, acusando-o de querer devorá-lo ou destruí-lo, de ter a intenção viciosa e ignóbil de apagar a diferença de um grupo menor, forçá-lo ou induzi-lo a se render ao seu próprio "ego coletivo", perder prestígio, dissolver-se [...].

Os Kalunga, grupo de remanescentes de quilombo localizado em um sítio histórico e patrimônio cultural, reconhecido pelo Estado brasileiro como comunidade quilombola de interesse social com direito ao título de sua terra, com tradições e saberes próprios organizados espacialmente pela sua história de resistência e luta pelo seu lugar e sua terra, ainda sofrem isolamento social perante os municípios em que estão inseridos, considerando sua situação de vulnerabilidade socioeconômica. 


\subsection{CARACTERIZAÇÃO SOCIAL E ECONÔMICA DA COMUNIDADE KALUNGA}

O isolamento geográfico e a exclusão social das comunidades quilombolas no Brasil são refletidas na situação de pobreza e vulnerabilidade em que hoje todas elas se encontram. Em “Por uma outra Globalização”, Santos (2012b, p. 129) afirma que:

A situação contemporânea revela, entre outras coisas, três tendências: 1. uma produção acelerada e artificial de necessidades; 2. uma incorporação limitada dos modos de vida ditos racionais; 3. uma produção ilimitada de carência e escassez. Nessa situação, as técnicas, a velocidade, a potência criam desigualdades e, paralelamente, necessidades, pois não há satisfação para todos.

As comunidades quilombolas não só ficaram excluídas do processo de expansão produtivo capitalista como do acesso aos programas e serviços públicos essenciais sob a obrigação do Estado brasileiro.

Pesquisa contratada pelo PNUD/MDS, "Avaliação da Situação de Segurança Alimentar e Nutricional em Comunidades Quilombolas Tituladas”, realizada em 2011 pela Fundação Euclides da Cunha/DataUFF por meio de estudo transversal de base populacional do tipo censo, com método quantitativo de coleta e análise de dados, permite avaliar o grau de vulnerabilidade e exclusão das comunidades remanescentes de quilombo que vivem em territórios titulados, de acordo com as seguintes variáveis: acesso aos serviços, benefícios e programas governamentais das famílias e perfil socioeconômico.

Para definição de vulnerabilidade, é considerada a classificação do Instituto Brasileiro de Geografia e Estatística- IBGE (2012), que diferenciou quatro grupo populacionais, mutuamente excludentes, conforme seus diferentes tipos de carência:

Vulneráveis por renda e por carências sociais - população com rendimento domiciliar per capita inferior a $60 \%$ da mediana e com ao menos uma das carências sociais listadas.

Vulneráveis por carências sociais - população com ao menos uma das carências sociais listadas, porém com rendimento domiciliar per capita superior a $60 \%$ da mediana.

Vulneráveis por renda - população com rendimento domiciliar per capita inferior a $60 \%$ da mediana, porém sem carências sociais. 
Não vulneráveis - população com rendimento domiciliar per capita superior a $60 \%$ da mediana e sem carências sociais.

A classificação da vulnerabilidade por carências sociais é mensurada através dos seguintes indicadores (IBGE, 2012):

Atraso educacional - foram consideradas carentes as crianças e adolescentes de 6 a 14 anos de idade que não frequentavam escola; as pessoas de 15 anos ou mais de idade analfabetas; e as pessoas de 16 anos ou mais de idade que não haviam concluído o ensino fundamental completo.

Qualidade dos domicílios - foram considerados carentes os residentes em domicílios com alguma das seguintes características: paredes que não fossem de alvenaria ou madeira aparelhada; telhado cujo material predominante não fosse telha, laje ou madeira aparelhada; e densidade de moradores por dormitório superior a 2,5 pessoas.

Acesso aos serviços básicos - foram considerados carentes os residentes em domicílios cujo abastecimento de água não fosse por rede geral; com esgotamento sanitário não realizado por rede coletora de esgoto ou fossa séptica; sem coleta de lixo direta ou indireta; ou sem iluminação elétrica.

Acesso à seguridade social - foram consideradas carentes as pessoas de 10 anos ou mais de idade que não contribuíam para instituto de previdência em qualquer trabalho ou que não eram aposentadas ou pensionistas de instituto de previdência. Residentes dos domicílios com rendimento domiciliar per capita inferior a $1 / 2$ salário mínimo em que nenhum membro recebesse rendimentos de outras fontes, o que inclui programas sociais.

De acordo com a pesquisa, praticamente todos os domicílios quilombolas apresentavam em 2011 algum tipo de vulnerabilidade, sendo que 76,37\% são vulneráveis por renda e carências sociais. A pesquisa demonstrou relação direta entre vulnerabilidade por renda e vulnerabilidade por carência social, pois a maior parte dos domicílios vulneráveis por renda são vulneráveis, consequentemente, por carência social. Porém, a relação contrária ocorre com menor intensidade. Finalmente, somente 23,4\% dos domicílios vulneráveis por carências sociais não possuíam vulnerabilidade por renda.

A vulnerabilidade da população quilombola, como pode ser verificado comparando-se o mapa de vulnerabilidade da população brasileira (figura 16) e a distribuição da vulnerabilidade nos territórios quilombolas por estado (figura 17), tem relação com a capacidade dos estados em que eles estão inseridos de prover serviços públicos e gerar renda.

A figura 16 mostra que as regiões Norte e Nordeste possuíam a maior concentração de 
população vulnerável por renda e por carências sociais. A figura 17 mostra a mesma tendência de distribuição regional de vulnerabilidade das comunidades quilombolas, porém com muito maior concentração de domicílios vulneráveis por renda e por carências sociais nos territórios quilombolas do que na média dos estados onde elas se situam.

Comparados com os dados de vulnerabilidade da população total do Brasil, os dados da população quilombola são bem alarmantes. Segundo a pesquisa do MDS, quase $100 \%$ dos domicílios quilombolas, das comunidades em terras tituladas, com exceção das comunidades de Sergipe, encontravam-se com algum tipo de vulnerabilidade, conforme pode ser verificado no mapa da figura 18. Porém, segundo dados do IBGE, a ser verificado no gráfico 2 adiante, cerca de 35\% da população brasileira não possuía nenhum tipo de vulnerabilidade em 2010. Portanto, nenhuma parte da população de territórios quilombolas está incluída no grupo populacional brasileiro sem vulnerabilidade de renda ou de carência social.

Mostramos neste capítulo que os Estados com maior concentração de territórios quilombolas titulados estão no Norte e Nordeste, Pará e Maranhão. De acordo com o mapa na figura 16, ambos eram também os estados com maior incidência de domicílios vulneráveis por renda e carência social, $43 \%$ a $53 \%$ dos domicílios paraenses e maranhenses. Nos domicílios de territórios quilombolas titulados desses Estados, a proporção de vulnerabilidade sobe para $73 \%$ a $81 \%$.

O mapa da figura 18 mostra que $81 \%$ da população quilombola do Pará eram vulneráveis por renda e carência social, com renda per capita média variando entre $R \$ 145$ e $\mathrm{R}$ \$ 168. Os estados análogos ao Pará em vulnerabilidade quilombola são Pernambuco e Piauí, onde $78,3 \%$ e 77,4\%, respectivamente, da população quilombola possuíam vulnerabilidade por renda e carência social. Em ambos a renda per capita dos quilombolas também variava entre $\mathrm{R} \$ 145$ e $\mathrm{R} \$ 168$.

No estado do Goiás, onde se encontra o Território Kalunga, 72,4\% da população quilombola estavam em situação de vulnerabilidade por renda e carência social, e os outros $27,6 \%$ estavam em situação de vulnerabilidade por carências sociais somente. Ou seja, 100\% eram vulneráveis, com a renda per capita variando entre $R$ \$ 169 e R 207. 
Segundo a pesquisa do MDS, o território Kalunga, quando analisados os números relativos, não estava em situação pior que a maior parte dos territórios quilombolas, pois as comunidades com poucos habitantes, como a comunidade de Imbiral no Maranhão, que possui somente 15 domicílios, acabam por ter maiores números relativos. Porém, em números absolutos, o território Kalunga, em Goiás, está em pior situação de vulnerabilidade. De 772 casas visitadas durante a pesquisa, 558 domicílios eram vulneráveis por renda e por carências sociais, o que representa $72 \%$ das casas Kalunga. 


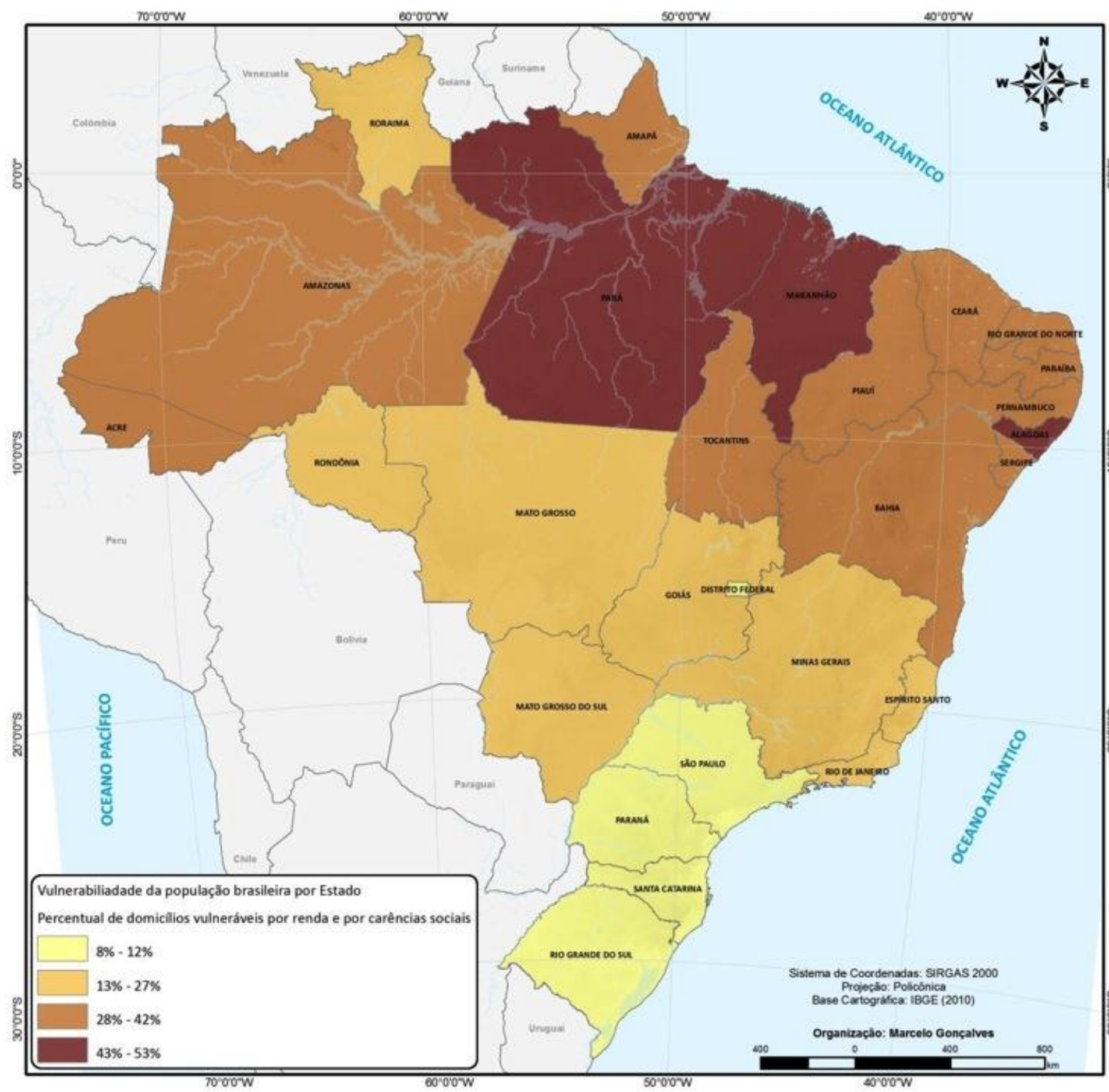

Figura 16- Vulnerabilidade da população brasileira por Estado. Fonte: IBGE, 2012. 


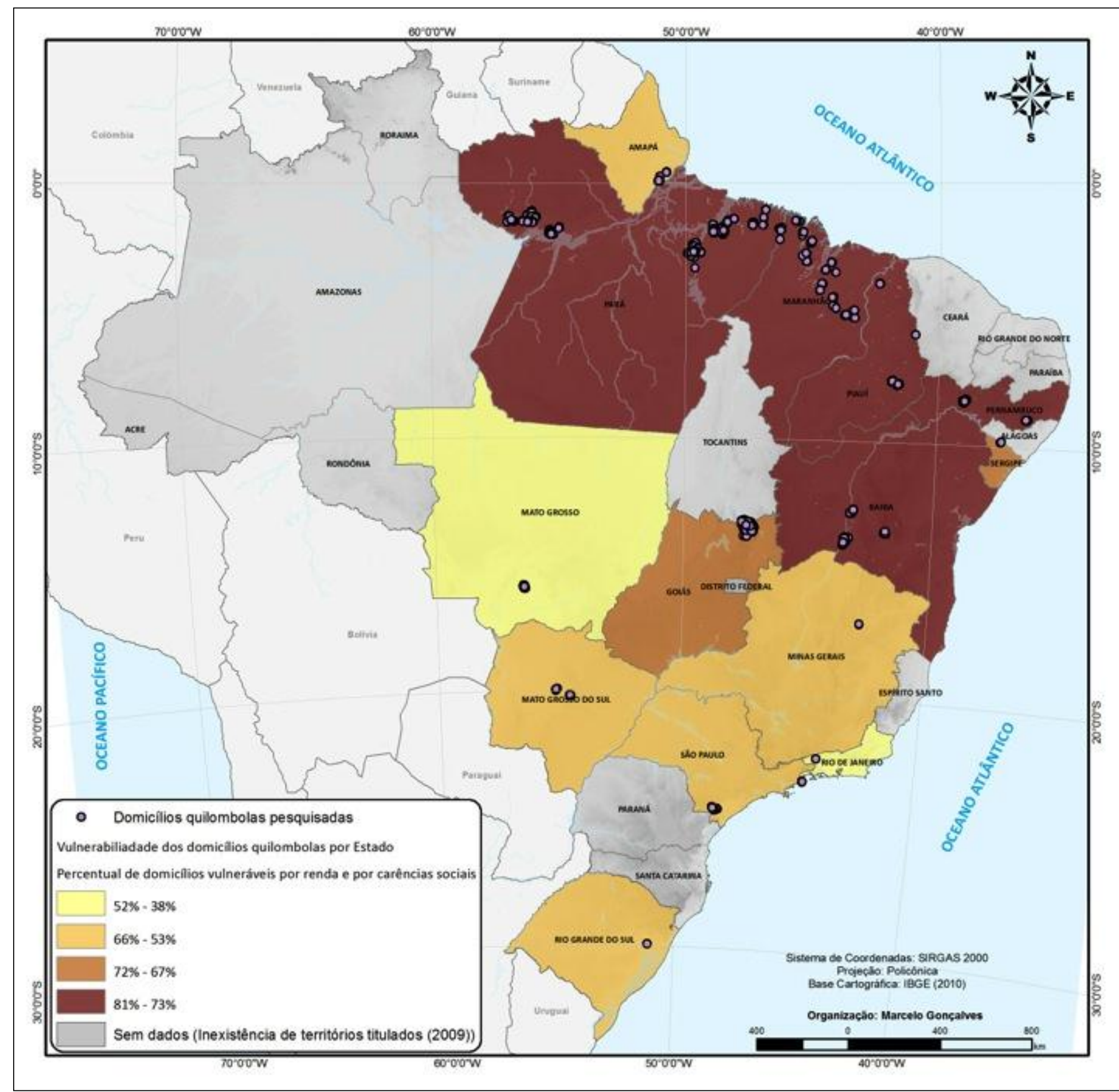

Figura 17- Distribuição da população quilombola por vulnerabilidade. Fonte: BRASIL, 2012 


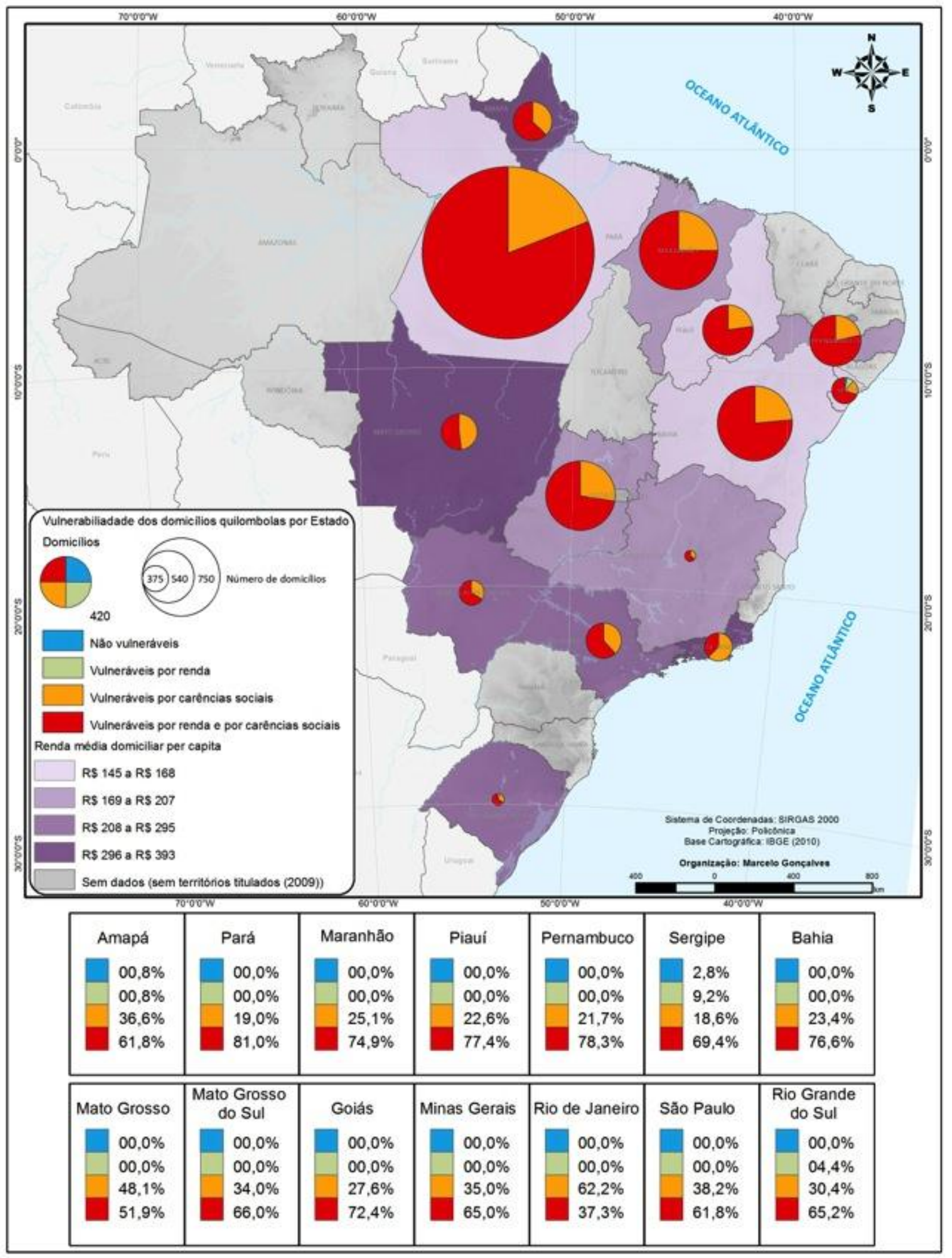

Figura 18- Vulnerabilidade e renda domiciliar per capita quilombola. Fonte: BRASIL, 2012 


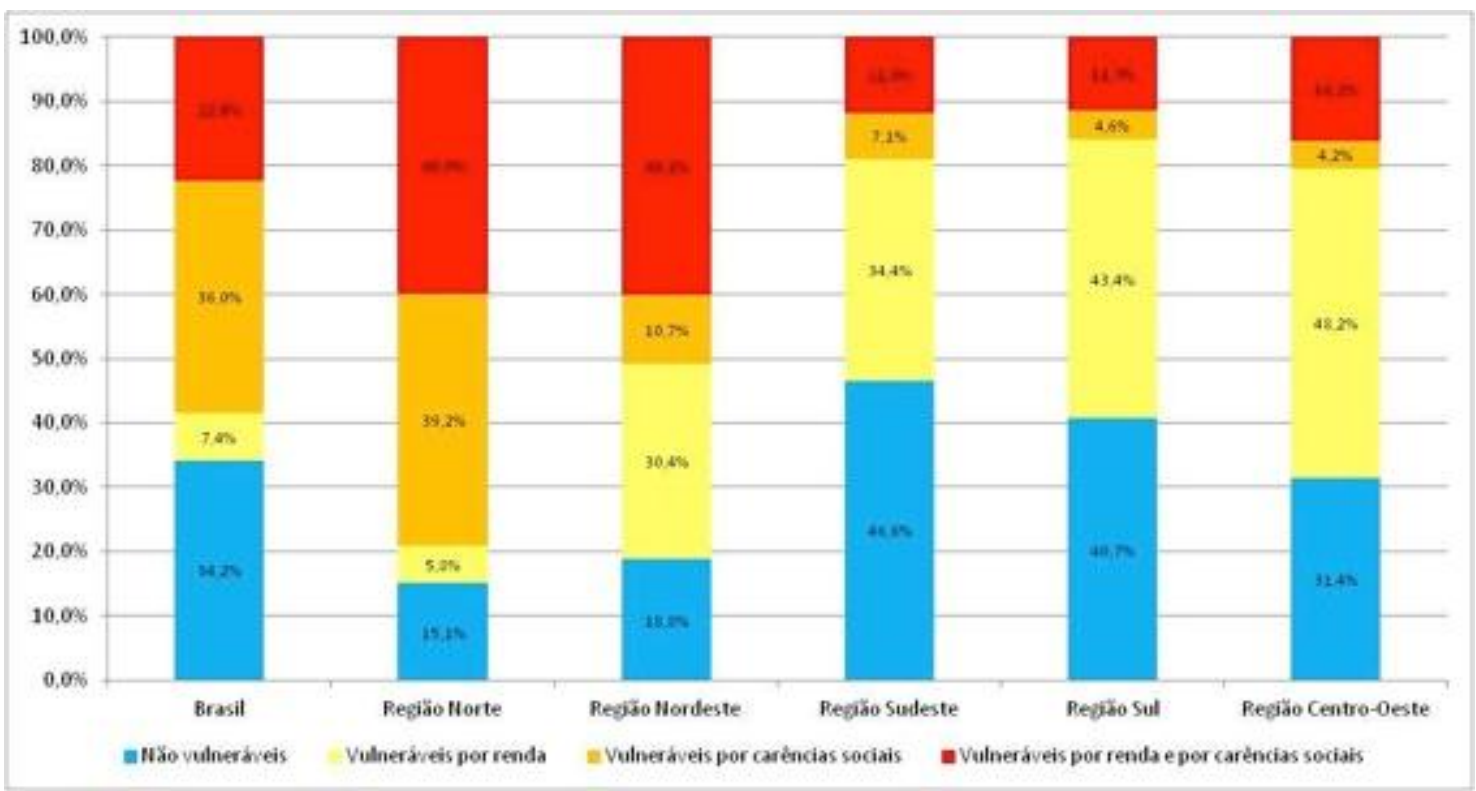

Gráfico 2- Distribuição da população brasileira por vulnerabilidade. Fonte: IBGE, 2012

Ainda na tentativa de demonstrar o contexto de vulnerabilidade que o Território Kalunga se encontra, é demonstrado no gráfico 3 que as populações quilombolas da Região Centro-Oeste aparecem com maior razão de dependência entre todos os grupos etários economicamente dependentes, comparadas às populações quilombolas de outras Regiões do Brasil, ultrapassando 95 dependentes para cada 100 pessoas em idades potencialmente ativas.

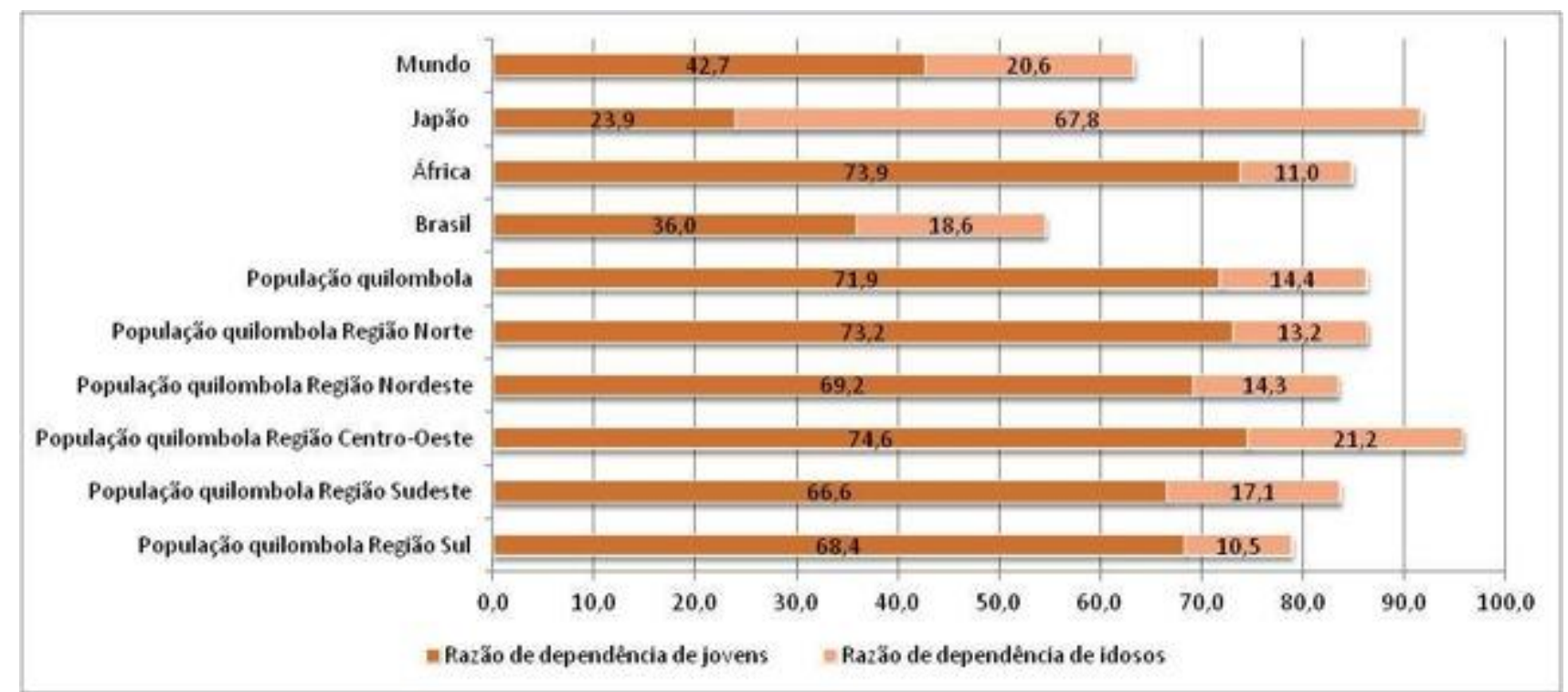

Gráfico 3- Razão de dependência de jovens e idosos. Fonte: World population prospects: the 2010 revision. New York: United Nations, Department of Economic and Social Affairs, 2011. Disponível em: <http://esa.un.org/unpd/wpp/index.htm>. Acesso em: out. 2012; IBGE, Pesquisa Nacional por Amostra de Domicílios (2011); BRASIL (2012) 
A figura 19, a seguir, demonstra que os Kalunga estão vulneráveis à insegurança alimentar e nutricional, de acordo com a Escala Brasileira de Medida Domiciliar de Insegurança Alimentar- EBIA, apesar de sua tradição em estratégias de produção para o autoconsumo. De acordo com a Pesquisa, somente 12\% dos domicílios Kalunga estão em situação de segurança alimentar, indicando que $70 \%$ estão em situação de insegurança alimentar leve ou moderada, e, o grupo mais preocupante, 18\%, estão em insegurança alimentar grave, indicando subnutrição ou desnutrição.

Em números absolutos, o território Kalunga possui, juntamente com Pau D’Arco, Parateca e Rio das Rãs na Bahia, os maiores índices de insegurança alimentar observados nas comunidades. Porém, relativamente, as comunidades com maior percentual de insegurança grave estão nos territórios de Bom Jesus/MA (82,1\%) e Imbiral/MA (78,6\%).

A segurança alimentar e nutricional é definida pela Lei Orgânica de Segurança Alimentar e Nutricional- Lei n¹1.346 de 2006 como "a realização do direito de todos ao acesso regular e permanente a alimentos de qualidade, em quantidade suficiente, sem comprometer o acesso a outras necessidades essenciais, tendo como base práticas alimentares promotoras de saúde, que respeitem a diversidade cultural e que sejam ambiental, cultural, econômica e socialmente sustentáveis".

A EBIA é composta de 15 perguntas, mas no caso da Pesquisa de Segurança Alimentar e Nutricional em Comunidades Quilombolas Tituladas foram consideradas 14, deixando de fora a pergunta relativa à perda de peso por falta de alimentos no domicílio. As respostas afirmativas constituem o escore que permitem a classificação da segurança alimentar e seus níveis de insegurança no domicílio. Ainda, para essa medição, todas as crianças abaixo de cinco anos são medidas e pesadas para avaliação quanto à desnutrição.

As perguntas da EBIA porém monetizam a segurança alimentar ao referir-se à falta de dinheiro como fator principal para a preocupação com o fim do alimento na casa ou com o pouco alimento disponível. Em comunidades e povos tradicionais, em especial aqueles com a tradição de produção de alimentos para o autoconsumo, como os quilombolas, essas perguntas podem levar a sérios problemas de entendimento sobre o que se está perguntando, pois a falta de renda monetária, sendo um fato em grande parte dessas comunidades, pode levar ao entendimento de que a falta de dinheiro é a principal questão sendo avaliada. 


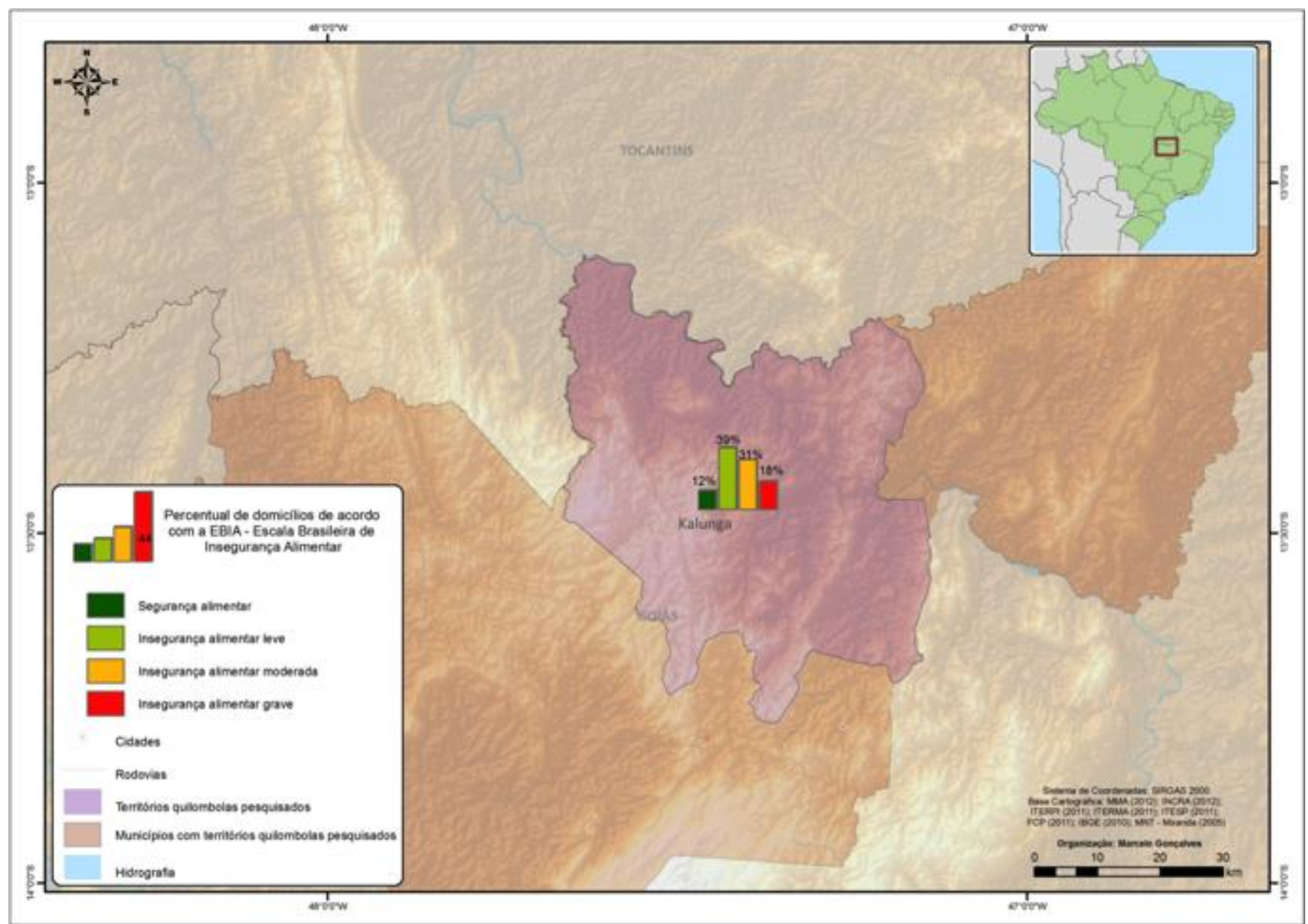

Figura 19- Situação da Segurança Alimentar e Nutricional da Comunidade Kalunga. Fonte: Brasil, 2012. 
Os Kalunga se encontram em maior situação de pobreza e vulnerabilidade também em comparação ao centros urbanos dos municípios em que estão inseridos: Monte Alegre, Teresina e Cavalcante, pequenos municípios do nordeste goiano.

De acordo com o Atlas de Desenvolvimento Humano no Brasil 2013 (PNUD, 2013) plataforma de consulta ao Índice de Desenvolvimento Humano Municipal-IDHM ${ }^{8}$ de 5.565 municípios brasileiros, o Índice de Desenvolvimento Humano Municipal dos três municípios do nordeste goiano estão bem abaixo da média nacional, sendo o IDHM de Cavalcante o pior do Estado de Goiás, conforme demonstrado no gráfico 4, abaixo.

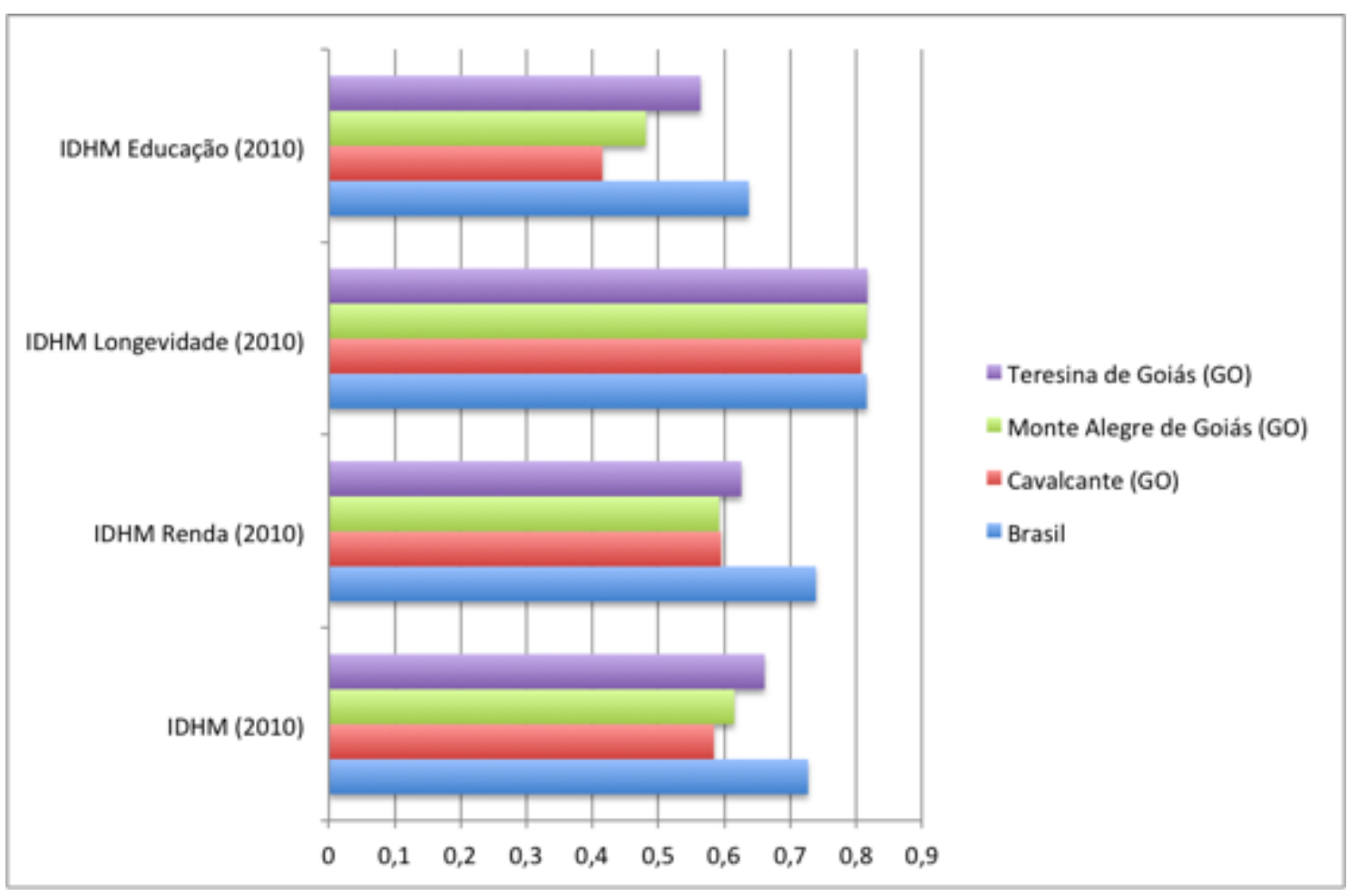

Gráfico 4- Índice de Desenvolvimento Humano Municipal dos municípios onde o Território Kalunga está inserido. Fonte: PNUD, 2013

Localizada nas zonas rurais de Cavalcante, Monte Alegre e Teresina de Goiás, a comunidade Kalunga retrata desenvolvimento desigual em relação à zona urbana desses

\footnotetext{
${ }^{8} \mathrm{O}$ IDHM varia entre 0 e 1 . Quanto mais próximo de 1 , maior o desenvolvimento humano de um município. Para seu cálculo são levados em conta 180 indicadores ligados a renda, educação e longevidade, popularizando o conceito de desenvolvimento centrado nas pessoas, não se limitando ao crescimento.
} 
municípios, que também se encontram em situação de pobreza em sua totalidade. De acordo com dados do Censo Demográfico de 2010, os níveis de extrema pobreza9 rural foram duas vezes maiores que o de extrema pobreza urbana nos municípios de Monte Alegre, Teresina e Cavalcante, respectivamente: $33,1 \%$ contra $12,9 \%, 34,4 \%$ contra $9,1 \%$ e $39,8 \%$ contra $19,8 \%$.

A taxa de analfabetismo das pessoas de 10 anos ou mais também foi mais que o dobro na zona rural: em Monte Alegre, 27,4\% na zona rural contra $16 \%$ na urbana; em Teresina, $22,2 \%$ contra $11,3 \%$, em Cavalcante, $34,6 \%$ contra $13,2 \%$.

Dos 7.730 habitantes registrados no Censo 2010 em Monte Alegre, 1.095 famílias (4.308 habitantes, considerando a média de quatro habitantes por família), equivalentes a 55\% dos habitantes, estavam na faixa de pobreza10. No Cadastro Único, em outubro de 2014, constavam 1.191 famílias beneficiárias do Programa Bolsa Família - PBF, ou seja, na faixa de pobreza, apresentando uma cobertura de 108,8\% da estimativa do Censo 2010. Das famílias beneficiadas pelo Programa, 410, correspondentes a 35\% dos beneficiários, eram quilombolas. Vale destacar que o Cadastro apresentou o registro de 564 famílias quilombolas no município em outubro de 2014. Se 410 são beneficiárias do PBF, conclui-se que $73 \%$ das famílias quilombolas estão em situação de pobreza em Monte Alegre.

Em Teresina de Goiás, o Censo 2010 registrou 3.060 habitantes, sendo que 302 famílias, cerca de 1208 habitantes, cerca de $40 \%$ da população, estavam na faixa de pobreza. Em outubro de 2014, o Cadastro Único apresentou o registro de 477 famílias beneficiárias do PBF, o que representa um cobertura de $157,9 \%$ da estimativa do Censo. Das famílias beneficiárias do PBF, 226, 47\%, eram quilombolas. Como constavam 311 famílias quilombolas no município e 226 eram beneficiárias do PBF, vale afirmar que $73 \%$ dos quilombolas de Teresina estão em situação de pobreza.

Em Cavalcante, a situação ainda se agrava para os quilombolas. Dos 9.392 habitantes registrados no Censo 2010, 1.327 famílias, equivalente a cerca de 5.308 pessoas, ou seja mais de 50\%, estavam em situação de pobreza. Em outubro de 2014, 1238 famílias eram beneficiárias do PBF, o que representa uma cobertura do Programa de 93,3\% da estimativa de

\footnotetext{
${ }^{9}$ Considera-se extrema pobreza o corte de renda adotado pelo Governo Federal para o Programa Brasil Sem Miséria de $R \$ 70,00$ per capita mensal.

${ }^{10}$ Considera-se pobreza o corte de renda adotado pelo Governo Federal para o Programa Bolsa Família de $\mathrm{R} \$ 140,00$ per capita mensal.
} 
famílias no perfil de famílias pobres. Dentro do universo de famílias beneficiárias, 638, ou seja, 51\%, eram quilombolas. Considerando que o Cadastro apresentou 1.092 famílias quilombolas no município, $58 \%$ dos quilombolas são beneficiários do PBF, ou seja, estão em situação de pobreza. Como a cobertura do Programa está abaixo do estimado de famílias pelo Censo, esse número pode ser ainda maior.

Segundo dados do Cadastro Único no sítio eletrônico do MDS, em outubro de 2014, 1.967 famílias, cerca de 7.868 habitantes, estavam registradas como quilombolas nos três municípios que compõem o Território Kalunga. Destas, 1.274 famílias eram beneficiárias do $\mathrm{PBF}$, o que equivale a dizer que pelo menos $65 \%$ das famílias Kalunga possuíam renda per capita de até $\mathrm{R} \$ 140$, enquadrando-se na faixa de pobreza.

A pesquisa do MDS sobre a situação de segurança alimentar e nutricional em comunidades quilombolas tituladas mostrou que somente $41,7 \%$ dos entrevistados declararam possuir trabalho, e destes, cerca de $90 \%$ estavam na informalidade. Dentre os quase $60 \%$ que declararam não estarem trabalhando, somente $12,3 \%$ afirmaram estar procurando emprego. $\mathrm{O}$ percentual de trabalhadores formais das comunidades quilombolas tituladas foi somente de $8,8 \%$ enquanto que, em 2011, mesmo período da realização do trabalho de campo da pesquisa, 56\% da população trabalhadora possuía trabalho formal, segundo a PNAD 2011.

A produção por meio do trabalho formal no Território Kalunga está em situação agravada em relação à média das comunidades tituladas, uma vez que somente $8,3 \%$ declaram possuir trabalho. Destes, $14,5 \%$ tinham carteira assinada. Dentre os que não estavam trabalhando, somente $9,4 \%$ declararam estarem procurando emprego.

O gráfico 5, abaixo, mostra a distribuição da organização de trabalho, segundo a categoria de formal ou informal, nas comunidades quilombolas tituladas. No território Kalunga, (ver estado de Goiás no gráfico 5), dos que estavam trabalhando, 84,2\% estavam na informalidade em 2011. 


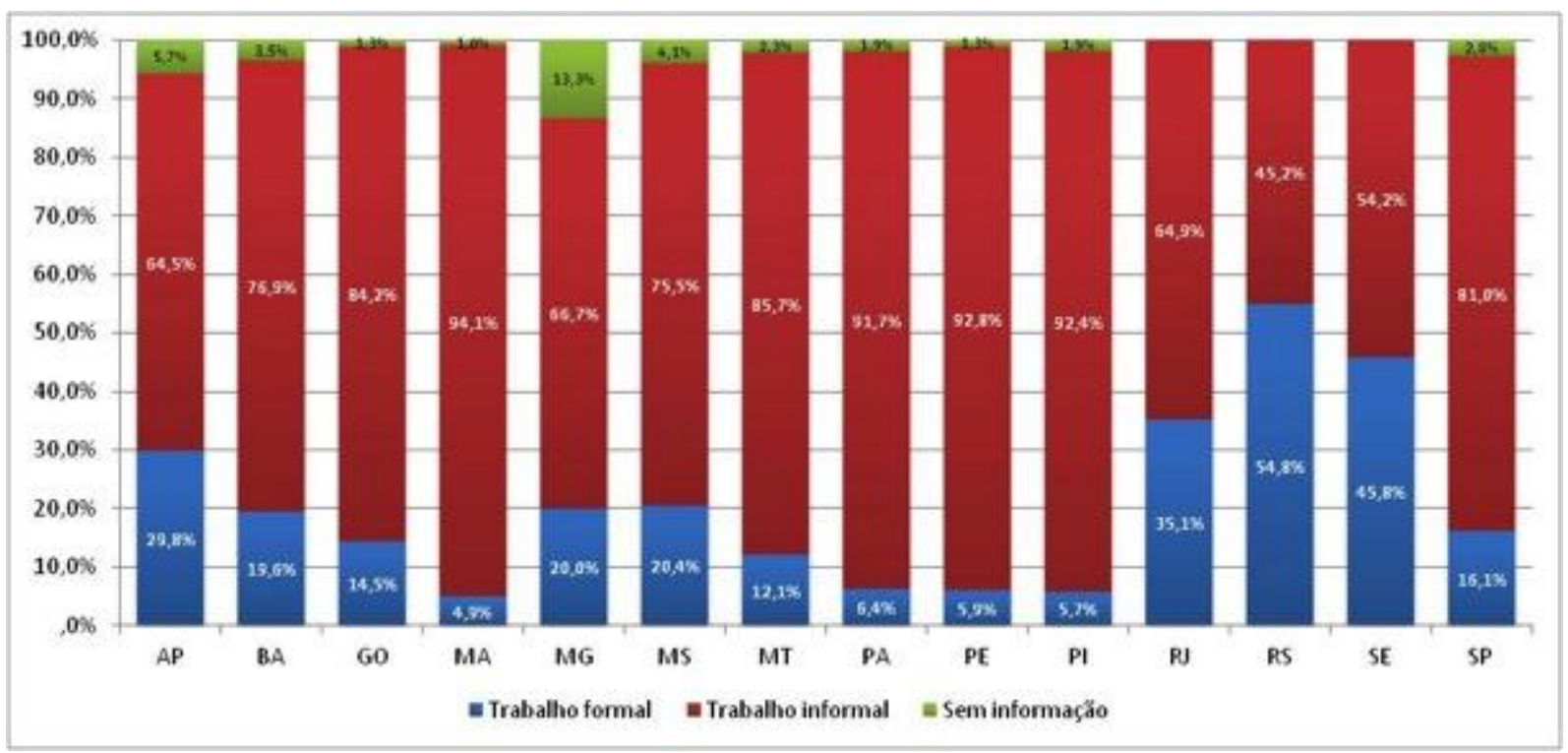

Gráfico 5- Distribuição das formas de organização no trabalho das famílias quilombolas. Fonte: BRASIL, 2012

Os dados da pesquisa em referência, conforme pode ser verificado no gráfico acima, mostram que os territórios quilombolas que estão inseridos nas cidades ou têm maior proximidade com os centros urbanos alcançam maior acesso ao trabalho formal, como os de Campo Grande/MS, Rio de Janeiro/RJ e de grande Porto Alegre/RS, onde o percentual de trabalho está acima de 30\%. Esse fato reforça que:

As condições atuais de crescimento capitalista criaram uma forma particular de organização do espaço, indispensável à reprodução das relações econômicas, sociais e políticas. As formas como atualmente se distribuem as infraestruturas, os instrumentos de produção, os homens- enfim, as forças produtivas- possui até certo ponto um caráter de permanência, isto é, de reprodução ampliada, isso amparado, exatamente, na longevidade de um grande número de investimentos fixos. Tudo, pois, conspira para que a organização do espaço se perpetue com as mesmas características, favorecendo o crescimento capitalista. (SANTOS, 2012, p. 73)

O cruzamento de dados entre emprego formal e renda mostra a importante relação entre essas variáveis.

De acordo com os rendimentos informados na Pesquisa de Segurança Alimentar e Nutricional nas Comunidades Quilombolas Tituladas, observou-se que o patamar mínimo 
brasileiro, referente a $60 \%$ da renda mediana ${ }^{11}$, é quase três vezes superior à renda mediana dos trabalhadores quilombolas do Brasil, que foi de $\mathrm{R} \$ 83,14 \mathrm{em} 2011$. A renda mediana do Brasil foi de $\mathrm{R} \$ 545,00$, no mesmo período, e o patamar mínimo estimado, considerando-se todos aqueles com rendimentos inferiores a $60 \%$ da mediana, foi de R $\$ 327,00$ (IBGE, 2012).

Utilizando-se a escala de análise por região (figura 11), os territórios dos trabalhadores quilombolas refletem a desigualdade territorial do Brasil, pois as regiões norte e nordeste apresentaram menor renda per capita dos domicílios quilombolas, variando entre $\mathrm{R} \$ 70,01 \mathrm{e}$ $\mathrm{R} \$ 255,00$ no nordeste e norte. A grande parte das comunidades quilombolas que apresentaram renda variando entre $\mathrm{R} \$ 255,01$ a 510,00 estão situadas na parte centro-sul do país.

Na região centro-oeste, onde está localizado o Território Kalunga, a renda média per capita variou entre $\mathrm{R} \$ 140,01$ a $\mathrm{R} \$ 255,00$.

A Pesquisa do MDS mostrou que, em 2011, 10\% dos entrevistados tinham como origem da renda a aposentadoria e que somente $4,4 \%$ declaram obter renda por meio da venda de produtos agropecuários.

\footnotetext{
${ }^{11}$ Para definir a renda mediana, o IBGE (2012) utiliza a forma de mensuração da pobreza aplicada pelos estatísticos europeus - que é aquela que calcula, de forma relativa, os rendimentos da população que se situa abaixo de um patamar definido arbitrariamente.
} 


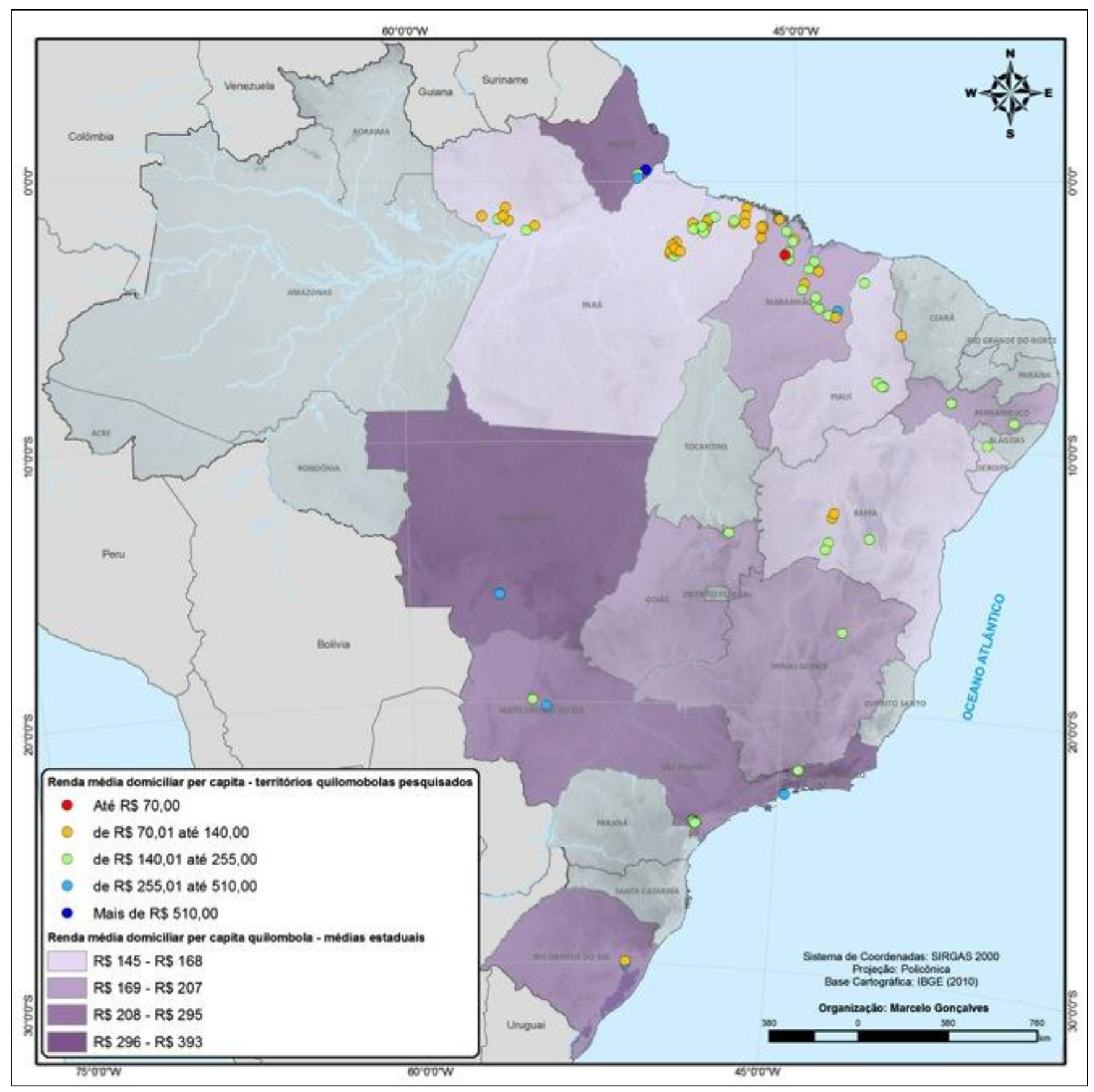

Figura 20- Rendimento médio per capita dos domicílios quilombolas titulados- médias estaduais- 2011. Fonte: BRASIL, 2012 
O acesso à terra não tem sido suficiente para geração de oportunidades de geração de renda para os Kalunga, uma vez que lhes falta, em grande parte dos povoados, infraestrutura e recursos para produção agrícola. Esse ponto será melhor tratado nos capítulos 2 e 3 adiante, em que a oportunidade dos Kalunga de ter acesso a políticas públicas será tratada mediante informações observadas na pesquisa de campo.

A pobreza dentro do território Kalunga é retratada na pesquisa além do aspecto renda. Segundo Santos (2006, p. 71) "o espaço é a síntese, sempre provisória, entre o conteúdo social e as formas espaciais". Assim, a qualidade precária das moradias, a falta de acesso a serviços públicos essenciais como saúde, educação, energia elétrica, água potável encanada e saneamento, caracterizam a realidade social em que vivem os Kalunga.

Das 772 casas visitadas pela equipe da Pesquisa do MDS, somente 35,6\% são em alvenaria e apenas $44,4 \%$ possuíam energia, seja da rede, de gerador ou solar. Outros 43,9\% ainda vivem com a luz gerada pela lamparina de querosene, e 10,3\% não possuem nenhuma forma de iluminação. Ainda, 58,5\% não possuem vaso com descarga. O escoamento das casas, quando há, é para fossas, em $43 \%$ dos casos, ou, em 55,9\% das casas, o escoamento é a céu aberto.

Quanto ao acesso à água, a grande maioria utiliza as águas dos rios e nascentes, seja por encanamento da água das nascentes nas serras, valendo-se da gravidade, ou buscando a água com baldes e tambores nos rios e córregos. A pesquisa identificou somente $38,1 \%$ das casas com água encanada em pelo menos um dos cômodos. A água das nascentes ou dos rios é utilizada para a limpeza, para o banho e também para beber, sendo que, neste caso, $98 \%$ declaram filtrar a água.

Acesso a serviços públicos de saúde e educação são dificultados pela falta de infraestrutura dentro do território Kalunga. Somente $25 \%$ declaram haver transporte escolar em sua comunidade, tendo as crianças que se deslocarem para as escolas, que em grande parte das comunidades oferecem somente até o ensino fundamental, a pé, de barco ou bicicleta.

Escola de ensino médio e posto de saúde somente foram identificados na comunidade do Engenho II, com acesso restrito a somente 140 famílias, pois não há estradas de ligação entre as outras comunidades e o Engenho II. Para frequentar o ensino médio ou ir ao médico, os moradores de grande parte dos povoados Kalunga devem se deslocar até a cidade sede de 
seu município por meio de transporte privado - caminhões chamados pau-de-arara, pois não há oferta de transporte público coletivo pelo município.

Os indicadores sociais relatados pela Pesquisa do MDS permitem tirar uma fotografia dos fenômenos sociais observados durante o trabalho de campo.

Um Indicador Social é uma medida em geral dotada de significado social substantivo, usado para substituir, quantificar ou operacionalizar um conceito social abstrato, de interesse teórico (para pesquisa acadêmica) ou programático (para formulação de políticas). É um recurso metodológico, empiricamente referido, que informa algo sobre um aspecto da realidade social ou sobre mudanças que estão se processando na mesma. (JANNUZZI, 2009, p. 15)

O conteúdo informacional dos indicadores sociais mostra a realidade objetiva de determinados aspectos da população quilombola, em especial do "nível de atendimento de necessidades materiais básicas para sobrevivência e reprodução social da comunidade" (JANNUZZI, 2009, p.19), que nos permite inferir alguns aspectos sobre as condições de vida da população quilombola.

Porém, aspectos relacionados a juízos de valor, interpretativos da realidade social dos Kalunga serão abordados no capítulo 3 , no qual serão relatadas observações durante a pesquisa de campo e a fala Kalunga sobre sua qualidade de vida e desenvolvimento espacial.

No mais, os indicadores sociais apresentados evidenciam a não inserção do espaço quilombola como "veículo do capital” (SANTOS, 2012) pela Estado brasileiro, sendo o espaço dos quilombos retrato da desigualdade social no Brasil, com pouco acesso a bens e serviços considerados essenciais e à produção capitalista de trabalho.

É importante destacar que os dados da pesquisa do MDS mostram uma fotografia do lugar no ano de 2011 e os dados do Censo mostram a fotografia de 2010. Segundo Santos "os cortes no tempo nos dão situações em um determinado momento. Não captam o movimento, são apenas uma fotografia" (SANTOS, 2014, p. 104). Por trás dos dados, não podemos deixar de enxergar o movimento, a luta diária dos Kalunga para ampliar suas capacidades e autonomia. Esses elementos serão melhor discutidos no capítulo 3 desta pesquisa. 
"Eu pego meu dinheirinho de minha aposentadoria, eu não gosto de jogar no mato. A senhora tá vendo esse pasto verdinho aí? Eu que paguei o trator e mandei gradear, comprei semente de R\$180 o saco e mandei plantar."

SEU ALBERTINO, 70 ANOS , 18 FILHOS.

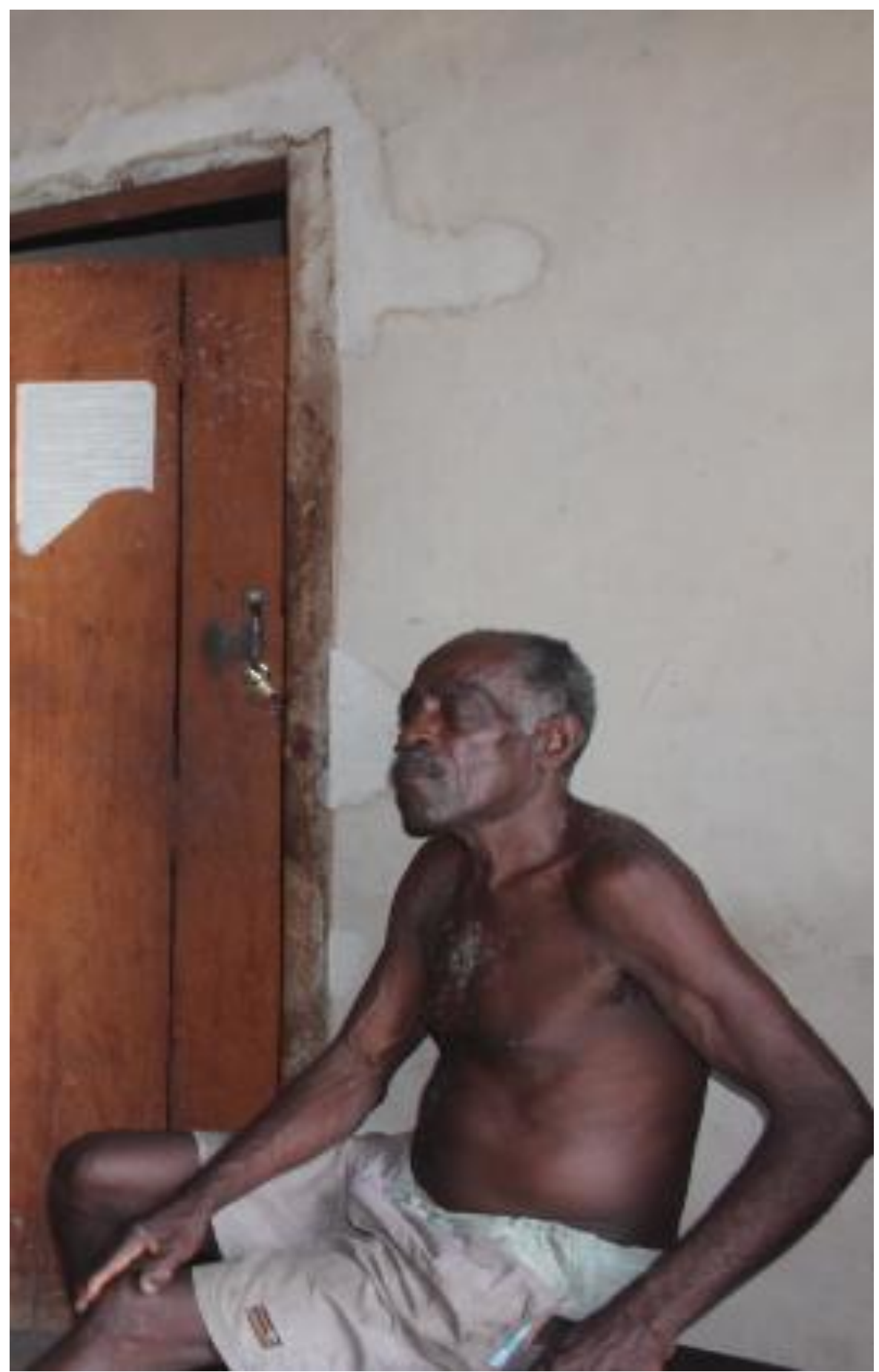




\section{CAPÍtULOO 2}

\section{POLÍTICAS PÚBLICAS E DESENVOLVIMENTO}

\subsection{DESENVOLVIMENTO COMO LIBERDADE E O PAPEL DO ESTADO}

O legado da escravidão ainda causa impactos na qualidade de vida da população negra brasileira. O Estado Brasileiro durante e depois do processo de abolição da escravatura no Brasil não promoveu a inclusão dos negros no sistema de produção e de propriedade já existente:

O trabalho escravo, núcleo do sistema produtivo do Brasil Colônia, vai sendo gradativamente substituído pelo trabalho livre no decorrer dos anos 1800. Essa substituição, no entanto, dá-se de uma forma particularmente excludente. Mecanismos legais, como a Lei de Terras, de 1850, a Lei da Abolição, de 1888, e mesmo o processo de estímulo à imigração, forjaram um cenário no qual a mão-de- obra negra passa a uma condição de força de trabalho excedente, sobrevivendo, em sua maioria, dos pequenos serviços ou da agricultura de subsistência. (THEODORO, 2008, p. 15)

A acumulação econômica dos brancos do centro sul do país por mais de 300 anos é retratada pelos indicadores sociais da Pesquisa Nacional por Amostra de Domicílios- PNAD 2011, que apontam que os negros e pardos do Brasil, apesar de representarem, naquele ano, $51,3 \%$ da população, estão em situação de desigualdade étnica-racial.

A taxa de analfabetismo (15 anos ou mais) entre negros e pardos em 2011 era duas vezes maior que a de brancos, $11,8 \%$ contra 5,3\% respectivamente. Os negros ou pardos em extrema pobreza também eram o dobro da proporção de brancos, 5,7\% contra 2,5\% respectivamente. O percentual de crianças negras ou pardas em trabalho infantil era de 4,9\% contra 3,2\% de crianças brancas. O rendimento mensal médio de todos os trabalhos era de $\mathrm{R} \$$ 927,90 entre negros e pardos e $\mathrm{R} \$ 1.524,91$ entre brancos.

Baseada na expropriação da pessoa escrava, a escravidão repercute na pobreza e injustiça social atual, imposta por uma visão social de mundo da classe dominante, que repete secularmente que os pobres são "preguiçosos", "vagabundos" e "não gostam de trabalhar". A visão liberal nega que o sofrimento dos pobres seja provocado por um arranjo institucional e social que não se responsabiliza pela histórica opressão social sobre os pobres, em especial aqueles pertencentes a grupos étnicos marginalizados, como os remanescentes de quilombo. Não sendo encarado como um problema da sociedade ou do Estado, 
O sofrimento social é naturalizado, ou remetendo-se à natureza individual (as características do indivíduo em questão o levam a ser pobre: ele é fraco, é uma criança, é um idoso, é doente, tem deficiências, etc.), ou apelando-se para leis econômicas que são apresentadas como sendo leis naturais, imutáveis e independentes da ação humana. (REGO, PINZANI, 2013, p. 44)

Porém, é preciso que a pobreza não seja tratada no nível de indivíduos. A organização do espaço é que reproduz as relações econômicas, sociais e políticas. A histórica distribuição de infraestrutura no centro-sul brasileiro, por exemplo, permite a longevidade da prosperidade e das distorções do crescimento capitalista da região. Santos (2012. p.74) apresenta como imperativo uma mudança da estrutura espacial, dando a todos os homens "o direito a um emprego e uma acessibilidade igual a todos os bens e serviços considerados essenciais".

Entendendo que "cada estrutura do todo reproduz o todo" (SANTOS, 2012, p.75), a discussão sobre desigualdade e pobreza vai além de questões nacionais relacionadas a crescimento econômico, como Produto Nacional Bruto, renda média e modernização tecnológica. Sem desconsiderar a importância desses indicadores para a medida de desenvolvimento de um país, propõe-se neste estudo entender como o aumento da renda e a introdução de disposições sociais como serviços públicos de saúde e educação contribuem para o processo de desenvolvimento, tendo como referência a ampliação de liberdade real desfrutada pelas pessoas.

Para Sen (2010), apesar do crescimento econômico dos países, liberdades substantivas ainda são negadas à grande maioria das pessoas. A fome, a desnutrição, o analfabetismo, a ausência de assistência médica, o não acesso à água e a falta de instituições legislativas ou judiciárias que garantam direitos sociais, políticos e civis, entre tantas outras precariedades, resultam na negação da liberdade das pessoas de não só participarem da vida social, política e econômica, mas também de realizarem suas escolhas e de se responsabilizarem por suas decisões.

Entender o desenvolvimento como liberdade não significa abandonar conceitos restritivos de desenvolvimento econômico e sim acrescentar ou expandir o conceito para se entender a finalidade do uso de mercados. Sen ressalta a necessidade de uma boa regulamentação pública a fim de diminuir o custeio social das sociedades orientadas para o mercado:

É difícil pensar que qualquer processo de desenvolvimento substancial possa prescindir do uso muito amplo de mercados, mas isso não exclui o custeio 
social, da regulamentação pública ou da boa condução dos negócios do Estado quando eles podem enriquecer- ao invés de empobrecer- a vida humana. A abordagem aqui adotada propõe um modo mais amplo e inclusivo de ver os mercados do que o frequentemente invocado, seja para defender, seja para criticar o mecanismo de mercado. (SEN, 2010, p. 22)

Em uma abordagem de desenvolvimento mais ampla, Sen considera que a expansão da liberdade deva ser o fim primordial e o principal meio de desenvolvimento, o que ele intitula de "papel constitutivo" e "papel instrumental" da liberdade no desenvolvimento:

O papel constitutivo relaciona-se à importância da liberdade substantiva no enriquecimento da vida humana. As liberdades substantivas incluem capacidades elementares como por exemplo ter condições de evitar a fome, a subnutrição, a morbidez evitável e a morte prematura, bem como as liberdades associadas a saber ler e fazer cálculos aritméticos, ter participação política e liberdade de expressão etc. (SEN, 2010, p. 55)

Nessa perspectiva, a expansão de liberdades humanas básicas deve ser a base principal da avaliação de desenvolvimento. O desenvolvimento não tem sentido se as pessoas são privadas daquilo que elas valorizam, seja a liberdade de expressão ou participação social ou a simples condição de saber ler e entender um livro. Assim, as liberdades humanas devem ser parte integrante e não consequência do processo de desenvolvimento.

A relação instrumental ganha igual importância e não reduz o argumento de que a liberdade real das pessoas deva ser o maior fim do desenvolvimento. Algumas liberdades são, inclusive, condições para a realização de outras. Sen considera as seguintes liberdades instrumentais: "(1) liberdades políticas, (2) facilidades econômicas, (3) oportunidades sociais, (4) garantias de transparência, (4) segurança protetora" (SEN, 2010, p. 58, grifo do autor). Elas contribuem para aumentar as chances de uma vida livre, propiciando efeitos complementares umas às outras.

As liberdades políticas incluem desde a escolha dos governantes à participação social tanto na elaboração como na fiscalização da execução de políticas públicas. Estas muitas vezes estão associadas a liberdades econômicas ou a oportunidades de escolha de consumo, produção ou troca. A relação complementar ocorre, por exemplo, quando indivíduos com maior grau de liberdade econômica e com oportunidade de acesso à educação não se dispõem a "vender" um voto, não abrindo mão de sua liberdade política. 
As oportunidades sociais influenciam, da mesma maneira, a condução da vida privada de um indivíduo para levar uma vida saudável quando este tem acesso a um serviço público de qualidade, seja de educação, moradia, energia elétrica, de fornecimento de água potável, ou mesmo para intermediação de mão-de-obra e acesso ao mercado de trabalho, por exemplo. Esse indivíduo, por sentir confiança no Estado e em si mesmo, poderá se sentir motivado a participar mais ativamente de fóruns políticos da comunidade e atividades econômicas coletivas.

As garantias de transparência estão relacionadas à presunção de confiança mútua para viver em sociedade. Estão diretamente ligadas à sinceridade entre as pessoas, à honestidade, à clareza de papéis, às regras acordadas. São intimamente relevantes para garantir tanto liberdades políticas e econômicas quanto oportunidades sociais, ao inibirem práticas corruptas.

Finalmente, a segurança protetora, de acordo com Sen, é essencial para proporcionar uma rede de proteção social que impeça que as pessoas sucumbam à miséria e morram de fome, por exemplo. Está relacionada às disposições institucionais do Estado para garantir uma renda mínima em caso de desemprego, uma complementação de renda em caso de miséria, acesso à habitação popular, entre outros.

A relação entre desenvolvimento e expansão das liberdades não nega a relevância do crescimento econômico do Produto Nacional Bruto para aumentar a renda per capita da população, mas traz a prerrogativa de considerar os investimentos feitos pelo Estado para dispor de serviços públicos de qualidade de saúde, de educação, de saneamento básico e de políticas eficazes de reforma agrária, habitação, acesso a produção e mercado de trabalho, e, finalmente de uma rede de proteção social.

Complementarmente, é essencial que se viva em um Estado democrático de direito para se ter liberdade política e se beneficiar de suas implicações na expansão de capacidades. Adicionalmente, o papel das normas e dos costumes comuns em países democráticos como igualdade de gênero, igualdade racial, liberdade de manifestação do pensamento e de crença, inviolabilidade da vida íntima e da vida privada, liberdade de exercício do trabalho ou profissão, de associação e liberdade de locomoção em território nacional são de fundamental relevância para um processo de desenvolvimento com vistas a garantir a liberdade e a ampliação das capacidades das pessoas. 
Em territórios com governo democrático, o Estado tem papel positivo na garantia de direitos civis e políticos, que, em situação de crise, ganham grande relevância na luta por uma rede de segurança protetora, como é o caso de políticas distributivas, a saber: a criação de empregos ou a garantia de uma renda mínima no sentido de evitar a fome coletiva.

Portanto, desenvolvimento como liberdade implica investir na totalidade do espaço. A conquista de liberdades substantivas pelos grupos mais vulneráveis é possível se for considerada a estrutura espacial em que esses grupos se encontram para a elaboração, implementação e avaliação de políticas públicas, entendendo que:

A estrutura espacial é algo assim: uma combinação localizada de uma estrutura demográfica específica, de uma estrutura de produção específica, de uma estrutura de renda específica, de uma estrutura de consumo específica, de uma estrutura de classes específica e de uma arranjo específico de técnicas produtivas e organizativas utilizadas por aquelas estruturas e que definem as relações entre os recursos presentes. (SANTOS, 2012a, p.29)

Os territórios quilombolas, historicamente e espacialmente, são ironicamente marcados pela ausência de liberdades substantivas. Simbolicamente representam a luta de um grupo étnico-racial por um espaço de liberdade e conquista de dignidade humana. Porém, sua grande maioria carece da presença do Estado no provimento de disposições sociais que permitam o exercício da vida saudável e cidadã.

A interação entre as estruturas que compõem o espaço quilombola deve, portanto, ser mediada pela ação externa de políticas públicas capazes de transformar a realidade de injustiça social e restrição de liberdades. Considerando que "o mesmo impulso externo tem uma repercussão diferente segundo o sistema em que encaixou" (SANTOS, 2012a, p. 30), as políticas públicas para o desenvolvimento de territórios étnicos devem levar em consideração os elementos espaciais que definem esses territórios.

Um Estado com atuação positiva na busca pela ampliação das capacidades e liberdade das pessoas atua, consequentemente, na redução do sofrimento causado pela pobreza histórica e geograficamente construída pelo sistema de produção voltado para o mercado. Faz-se necessário, portanto, discorrer brevemente sobre o conceito de sociedade decente para discussão das agendas públicas afirmativas.

De acordo com Margalit (1996), uma sociedade descente é primariamente aquela cujas instituições não humilham seus indivíduos, sendo a humilhação uma situação que faz com que 
o indivíduo tenha boas razões para sentir que seu auto respeito foi ferido. A humilhação nesse caso refere-se a ações ou omissões estatais.

Portanto, o dever do Estado é de agir positivamente para proporcionar o desenvolvimento com liberdade real do seu povo bem como de se abster de agir negativamente por meio da opressão, discriminação e exploração. As políticas públicas afirmativas ganham força nesse sentido a fim de contribuir para o reconhecimento dos direitos de identidades étnicas e raciais que não usufruem do crescimento econômico das superestruturas.

"Em cada período, o Estado realiza um objetivo e possui função própria" (SANTOS, 2012, p. 86). A realização dos objetivos definidos em um Estado democrático a cada governo se dá por meio da políticas públicas.

Saravia (2006 ) define política pública como um fluxo de decisões públicas que orientam o equilíbrio social ou introduzem desequilíbrios que chegam a modificar essa realidade. Saravia (2006) destaca ainda que a racionalidade desse processo não se manifesta por meio de uma ordem tranquila em que cada ator social está ciente e desempenha seu papel.

O Estado brasileiro, ao definir, em 2003, como sua principal meta a exclusão da fome no país, assumiu o desafio de promover mudanças necessárias para o desenvolvimento com maior liberdade real para aqueles institucionalmente deixados à marginalidade do crescimento econômico. O primeiro passo, o de incluir a pauta na agenda pública foi dado. O problema foi reconhecido como sendo de nível público.

O processo de elaboração, que requer estabelecer as alternativas de solução - os custos e seus efeitos -, incluiu políticas de segurança alimentar e nutricional, de redução da pobreza, saúde preventiva - vacinação -, pré-natal, fornecimento intensivo de vitaminas e medicamentos para doenças crônicas, em educação infantil, básica, ensino superior e técnicoprofissionalizante, de geração de oportunidades de inclusão produtiva urbana e rural, entre outros.

No processo de formulação definiu-se os marcos jurídicos - que incluiu a elaboração de uma série de decretos e leis, as instâncias administrativas envolvidas e a estimativa de orçamento, que, segundo Saravia (2006), é o processo de a seleção e especificação da alternativa considerada mais conveniente, e que declara explicitamente a decisão adotada. 
A implementação de uma agenda de tamanha complexidade envolvia diversos atores órgãos públicos dos três entes federativos, conselhos de participação social, empresas privadas e públicas, e organizações da sociedade civil, exemplificando em uma lista não exaustiva. Para dar conta de uma implementação complexa alguns condicionantes deveriam ser satisfeitos: aprovação do orçamento pelo Congresso Nacional, órgãos fortalecidos de coordenação e comunicação, ambiente jurídico favorável, compreensão pelo atores de seus papéis e acordo sobre seus objetivos.

A Constituição de 1988 “criou o espaço jurídico necessário para o desenvolvimento de políticas de direitos no país" (REGO, PANZINI, 2013, p. 161). A existência de direitos individuais e sociais é o principal fundamento para a formulação de políticas públicas que os assegurem. O desafio para o Estado brasileiro está posto: "assegurar o exercício dos direitos sociais e individuais, a liberdade, a segurança, o bem-estar, o desenvolvimento, a igualdade e a justiça como valores supremos de uma sociedade fraterna, pluralista e sem preconceitos", conforme estabelece o preâmbulo da Carta Magna.

As relação de causa e efeito das políticas públicas de desenvolvimento devem estar pautadas, portanto, na construção de uma "sociedade livre, justa e solidária" e devem ter como fim "erradicar a pobreza e a marginalização e reduzir as desigualdades sociais e regionais", além de "promover o bem de todos, sem preconceitos de origem, raça, sexo, cor, idade e quaisquer outras formas de discriminação", conforme estabelecem os objetivos fundamentais da República Federativa do Brasil.

A Constituição Federal de 1988 trata de conceitos, princípios, competências, financiamento, planejamento, organização, instrumentos para formulação e execução das políticas públicas - como, por exemplo, o Título VII, que, entre outros, trata das políticas urbana e agrícola e fundiária; o Título VIII, que aborda as políticas de seguridade social; e, as Disposições Transitórias da CF, que incluem o direito territorial de indígenas e quilombolas sobre suas terras.

Porém, o ambiente jurídico exige mais do que a Constituição. Muitos de seus preceitos devem ser regulamentados por lei, além de exigir um sistema de normas de direito administrativo que favoreçam processos eficientes. Schwartz (1955, p. 283) ressalta a importância do processo administrativo para a consecução das políticas públicas: 
operation of government, the administrative process. When the constitutional process has resulted in a duly elected Government which has determined its policies and enacted any necessary primary legislation, the administrative process begins."

Ainda, disputas políticas, desarmonia entre os Poderes Executivo Legislativo e Judiciário, contingenciamento orçamentário, morosidade de processos administrativos, falta de acordos e de compreensão de seus papéis por agentes políticos e servidores públicos nas três escalas federativas, entre outros fatores, constituem obstáculos que devem ser previstos durante a execução da política pública, a fim de promover a consecução do direito constitucional.

As políticas públicas de combate à fome e de redução da pobreza e superação da extrema pobreza foram anunciadas como prioridade governamental nas gestões governamentais de 2003, 2007 e 2011. Com isso, a agenda social foi ampliada refletindo no aumento significativo de orçamento público ${ }^{12}$ destinado às políticas sociais, como transferência de renda, assistência social, desenvolvimento agrário e segurança alimentar.

Theodor Lowi (1964; 1972, apud Souza, 2006, p.28) desenvolveu quatro tipologias de políticas públicas: 1- distributivas, que, a despeito de qualquer limitação de recursos financeiros, procura tomar decisões que privilegiem certos grupos sociais ou regiões; 2regulatórias, que envolvem a regulação de grupos de interesse e políticos por meio da burocracia; 3 - redistributivas, que, ao envolver o maior número de pessoas possível, resulta na perda concreta no curto prazo para certos grupos sociais em prol de ganhos futuros, mas incertos, para outros, como é o caso de políticas universais como o sistema tributário e previdenciário; 4- constitutivas, que tratam de procedimentos.

Ao focalizar políticas de transferência de renda não contributiva para aqueles dentro de uma certa faixa de renda, ao direcionar programas de acesso à água na região nordeste, e, mais importante para os fins deste trabalho, ao priorizar um conjunto de políticas públicas já existentes para territórios quilombolas e indígenas, houve uma decisão do Poder Executivo de priorizar políticas distributivas, enfrentando os setores mais liberais, questionando as relações de propriedade, poder e prestígio social estabelecidas. Porém,

\footnotetext{
${ }^{12} \mathrm{O}$ orçamento da União em políticas sociais (funções saúde, educação, segurança pública, assistência social, previdência social, cultura, direitos da cidadania, urbanismo, habitação, saneamento, organização agrária e desporto e lazer) alcançou $R \$$ 744 bilhões em 2012, correspondendo a 16,9\% do PIB para o mesmo ano. Esse valor representa crescimento real de $128,2 \%$ com relação a 2000. (Plano Mais Brasil- PPA 2012-2015)
} 
tiende a ser lógicamente la arena más tensa y frontalmente conflictiva; las transacciones aquí son imposibles o con resultados poco significativos, puesto que el desenlace de estas cuestiones radicales afectará irremediablemente a numerosos sectores de la población en puntos cruciales de su existencia social" [...]" (VILLANUEVA, 1992, p.4)

Boneti (2007, p. 74) ressalta o jogo de forças e as disputas de grupos econômicos e políticos e de classes sociais em seu conceito de políticas públicas:

\begin{abstract}
Entende-se por políticas públicas o resultado da dinâmica do jogo de forças que se estabelece no âmbito das relações de poder, relações essas constituídas pelos grupos econômicos e políticos, classes sociais e demais organizações da sociedade civil. Tais relações determinam um conjunto de ações atribuídas à instituição estatal, que provocam o direcionamento (e/ou o redirecionamento) dos rumos de ações de intervenção administrativa do Estado na realidade social e/ou de investimentos.
\end{abstract}

Segundo Souza (2006, p. 32), “o modelo de arenas sociais vê a política pública como uma iniciativa dos chamados empreendedores políticos ou de políticas públicas”. A política pública ganha força por ser reconhecido amplamente que algo precisa ser feito, mesmo em detrimento de outras ações. Sociedade civil organizada, organismos internacionais, legisladores, juristas e policy makers (formuladores de políticas) investem tempo, recursos, e esforços por estarem convencidos de que um problema precisa estar na agenda pública, por motivos diversos:

[...] (a) divulgação de indicadores que desnudam a dimensão do problema; (b) eventos tais como desastres ou repetição continuada do mesmo problema; e (c) feedback, ou informações que mostram as falhas da política atual ou seus resultados medíocres. (SOUZA, 2006, p. 32)

Essa comunidade de empreendedores é envolvida em redes de conexões que se movimentam com o foco nas relações e trocas entre as diferentes entidades envolvidas. Souza (2006, p.32- p.33) explica que:

Este método e referencial teórico partem do estudo de situações concretas para investigar a integração entre as estruturas presentes e as ações, estratégias, constrangimentos, identidades e valores. As redes constrangem as ações e as estratégias, mas também as constroem e reconstroem continuamente.

Em resposta à demanda da sociedade civil organizada, movimentos sociais e da Organização das Nações Unidas, que convocou todos os países a acordar os objetivos do milênio de acabar com a fome e miséria, no fim da década de 1990 e início dos anos 2000, foi estabelecida a estratégia de desenvolvimento nacional - definida no Plano Plurianual - PPA 
2004-2007, e seguida nos PPAs 2008-2011 e 2012-2015. Procurou-se convergir a promoção da inclusão social e a melhoria da distribuição de renda de modo a efetivar os direitos estabelecidos pela Carta Cidadã de forma universal e institucionalizada. A estratégia de desenvolvimento proposta

[...] realiza a integração entre, por um lado, a inclusão social e a redistribuição de renda e, por outro, os investimentos e o crescimento da renda e do emprego. A universalização dos direitos sociais básicos e a transmissão dos ganhos de produtividade aos salários estabelecem a sinergia entre as políticas sociais e de investimento, promovendo o crescimento por meio da expansão do mercado de consumo popular. (PPA 2004-2007, p. 67)

Os arranjos de gestão implementados para criar condições de implementação das políticas sociais a partir de 2003 envolvem: a criação de órgãos como os Ministérios do Desenvolvimento Social e Combate à Fome e das Cidades, as Secretarias de Políticas para Mulheres e de Promoção da Igualdade Racial; a institucionalização de sistemas nacionais de políticas públicas, como o Sistema Único da Assistência Social- SUAS e o Sistema Nacional de Segurança Alimentar e Nutricional- SISAN; e a expansão de direitos como o direito à alimentação introduzido nos direitos sociais da Constituição Federal e o direito à educação pública e gratuita dos quatro aos 17 anos.

A estratégia de desenvolvimento enunciada nos Planos Plurianuais anteriores, desde 2004, é reforçada no Plano Plurianual - PPA 2012-1015, intitulado Plano Mais Brasil: conjugar crescimento econômico com redução das desigualdades sociais e regionais. Em sua dimensão social, o instrumento maior de planejamento de governo buscou institucionalizar e universalizar os direitos de cidadania, a melhoria da distribuição de renda e a promoção social dos segmentos populacionais mais vulneráveis.

Nesse sentido, o PPA 2012-2015 construiu, de forma inédita, nove "agendas transversais", compostas de programas e políticas de caráter transversal, buscando levar políticas setoriais como educação, saúde, assistência social, previdência, cultura, desenvolvimento urbano e rural, entre outros, a públicos e territórios vulneráveis como: mulheres, criança e adolescente, juventude, pessoa idosa, pessoa com deficiência, população $\mathrm{LGBT}^{13}$, população em situação de rua, indígenas e quilombolas e outros povos tradicionais.

\footnotetext{
${ }^{13}$ População LGBT - Lésbicas, Gays, Bissexuais e Transexuais.
} 
A inclusão de territórios étnicos, como indígenas e quilombolas, na agenda transversal do PPA mostra o avanço do Estado brasileiro na identificação de diferenças territoriais, reconhecendo as especificidades étnicas, além da tradicional divisão regional e federativa. $\mathrm{O}$ território usado por grupos historicamente excluídos do processo de desenvolvimento entra na disputa de orçamento público e de políticas inclusivas. Como resultado, espera-se a valorização da identidade e da diversidade da população e a redução das desigualdades territoriais, por meio do acesso pelas comunidades tradicionais a infraestruturas, acessibilidade, mobilidade e serviços públicos essenciais.

A abordagem espacial e territorial de políticas públicas exige que espaços geográficos demarcados por fatores étnico-raciais, ambientais e socioeconômicos estejam articulados com as diversas instâncias governamentais para ampliar suas capacidades e liberdades, ou seja, conquistar o desenvolvimento na concepção de Sen.

Portanto, a participação social e a criação de redes de populações tradicionais que demandem e ampliem condições sociais para a transformação da realidade são condicionantes para o protagonismo do seu espaço na esfera de políticas públicas transformadoras.

A efetiva participação popular quilombola no planejamento e formulação das políticas públicas, assim como na sua fiscalização, se deu por meio, principalmente, da Coordenação Nacional de Articulação das Comunidades Negras Rurais Quilombolas- CONAQ, que teve participação direta na construção do texto legal do Decreto 4887/2003 ${ }^{14}$, e da Comissão Nacional de Desenvolvimento Sustentável dos Povos e Comunidades Tradicionais- CNPCT, que conta com 15 participantes civis e 15 governamentais. Esta, criada em 2004 e modificada pelo Decreto $N^{\circ} 13$ de 2006 da Presidência da República, deve coordenar a implementação da Política Nacional de Desenvolvimento Sustentável dos Povos e Comunidades Tradicionais, instituída pelo Decreto $N^{\mathrm{o}} 6.040 / 2007^{15}$.

Outro espaço importante de participação e discussão de prioridades entre os representantes da sociedade civil e o governo são as Conferências Regionais e Nacionais. A ampla participação dos quilombolas nesses espaços foi motivada pela realização prévia de

\footnotetext{
${ }^{14}$ O Decreto 4887/2003 regulamenta o procedimento para identificação, reconhecimento, delimitação, demarcação e titulação das terras ocupadas por remanescentes das comunidades dos quilombos.

${ }^{15}$ A PNPCT definiu que Povos e Comunidades Tradicionais são grupos culturalmente diferenciados e que se reconhecem como tais, que possuem formas próprias de organização social, que ocupam e usam territórios e recursos naturais como condição para sua reprodução cultural, social, religiosa, ancestral e econômica, utilizando conhecimentos, inovações e práticas gerados e transmitidos pela tradição;
} 
Plenárias Nacionais das Comunidades Quilombolas, cujos participantes devem ser obrigatoriamente representantes das comunidades quilombolas, assegurando-se $30 \%$ de representação de quilombolas regionais de cada estado. Estas antecederam as três Conferências Nacionais de Promoção da Igualdade Racial, realizadas entre 2003 e 2014. A Plenária de 2012, inclusive, ocorreu na Chapada do Veadeiros, contando com grande participação dos Kalunga e outras comunidades do Centro-Oeste, em especial.

Alguns dos relevantes avanços resultantes das Conferências, de acordo com o Relatório do Conselho Nacional de Promoção da Igualdade Racial- CNPIR ${ }^{16}$, foram: 1- a aprovação da Lei $\mathrm{N}^{\circ}$ 12.990, de 9 de junho de 2014, com vigência de 10 (dez) anos a partir da sua publicação, que institui a reserva de vagas aos negros nos concursos públicos realizados pela Administração Pública federal, direta e indireta; e, 2- a regulamentação, por meio do Decreto $\mathrm{N}^{\mathrm{o}}$ 8.136, de 5 de novembro de 2013, do Sistema Nacional de Promoção da Igualdade Racial - SINAPIR, instituído pelo Estatuto da Igualdade Racial. O SINAPIR é um grande passo na institucionalização da definição de competências e responsabilidades para os entes federados participantes do sistema.

Ainda no âmbito da participação popular, o ano de 2014 foi marcado por cinco grandes Encontros Regionais de Povos e Comunidades Tradicionais, seguidos pelo Encontro Nacional realizado em dezembro daquele ano, ${ }^{17}$ com os objetivos de: 1 - realizar discussão do acesso aos territórios e à regularização fundiária; 2- realizar balanço das ações, políticas e programas relacionados à implementação da PNPCT; 3- elaborar proposições à implementação da PNPCT; 4- avaliar a atuação e o funcionamento da CNPCT; 5- propor alterações para a revisão das competências e constituição da CNPCT.

Com o fim de proporcionar um espaço democrático de discussão, além das reuniões em plenárias, os participantes eram divididos em grupos de trabalho divididos em quatro temas, que compuseram os eixos da PNPCT: 1- acesso aos territórios tradicionais e aos Recursos Naturais; 2- infraestrutura; 3- inclusão social; e, 4- fomento à produção sustentável.

\footnotetext{
${ }^{16}$ O CNPIR é um órgão colegiado de caráter consultivo e integrante da estrutura básica da SEPPIR/PR. É composto por representantes de 22 órgãos do Governo federal, de 19 entidades da sociedade civil, escolhidas por meio de edital público com processo eleitoral, e por três personalidades de reconhecida atuação na defesa das políticas de promoção da igualdade racial, indicados pela SEPPIR/PR.
}

17 As informações sobre o Encontro Nacional de Povos e Comunidades Tradicionais foram coletadas diretamente pela pesquisadora, que participou como ouvinte do Encontro realizado em Brasília em dezembro de 2014. Além disso, esta pesquisadora teve acesso ao Documento técnico contendo sistematização de demandas da CNPCT para aprimoramento das políticas para esse segmento, elaborado por consultor contratado pelo MDS, Marcelo Simon Manzatti. 
Após ampla discussão nos grupos, as conclusões eram levadas à plenária para concordância e consolidação.

Para os fins deste trabalho, destacam-se somente as demandas da população quilombola ${ }^{18}$ nos referidos Encontros que basicamente referiam-se às necessidade: 1- de maior inserção da política de educação nas comunidades, com construção de escolas até o ensino médio e profissionalizantes dentro dos territórios quilombolas, gestão adequada à realidade das comunidades, material apropriado para a educação quilombola, e com contratação de profissionais quilombolas; 2- gestão junto às prefeituras para que o Programa Nacional de Merenda Escolar seja cumprido e os quilombolas tenham autonomia para produzir e vender seus produtos de agricultura familiar para a merenda; 3- fortalecimento, com ampliação de recursos humanos e financeiros, de órgãos essenciais para a certificação e regularização das terras quilombolas como a Fundação Cultural Palmares e o INCRA, em especial nas suas representações locais e estaduais; 4- revitalização da infraestrutura - com acesso ao Luz para Todos, Minha Casa Minha Vida, Programa de Acesso à Água, Postos de Saúde, de territórios quilombolas urbanas e rurais, dialogando com as formas de organização espacial existente; 5- implementação da Política Nacional de Saúde da População Negra, buscando o apoio das universidades, conselhos e outras organizações, e em especial do Programa de Anemia Falciforme nas comunidades quilombolas; 6- acesso a saneamento básico nas comunidades; 7- apoio técnico para gestão dos territórios quilombolas regularizados; 8- incentivo à permanência dos quilombolas nos seus territórios por meio de programas de geração de renda e inclusão produtiva, em especial de apoio à produção agrícola e melhoria ou construção de estradas vicinais para escoamento da produção, capacitação para empreendedorismo e cooperativismo e acesso a microcrédito, ; e, 9articulação e diálogo com os grandes empreendimentos com o objetivo de evitar aprovação de projetos que tenham impacto nos territórios quilombolas.

As demandas dos quilombolas ao Estado retratam o reconhecimento dessa população da necessidade de se reconhecer o conceito de espaço como território usado como referência para os processos sociais necessários ao desenvolvimento.

\footnotetext{
18 Além das Comunidades Quilombolas, o Encontro Nacional de Povos e Comunidades Tradicionais reuniu: Povos Ciganos, Povos Indígenas, Extrativistas, Andirobeiras, Apanhadores de Flores Sempre-Vivas, Benzedeiros/as, Caatingueiros, Caboclos, Caiçaras, Catadoras de Mangaba, Faxinalenses, Fundo e Fecho de Pasto, Geraizeiros, Ilhéus, Marisqueiras, Morroquianos, Pantaneiros/as, Pescadores/as Artesanais, Pomeranos/as, Povos e Comunidades de Terreiros/Matriz Africana, Quebradeiras de Coco Babaçu, Raizeiras, Retireiros do Araguaia, Ribeirinhos, Seringueiros/as, Vazanteiros e Veredeiros.
} 
O conceito de território tradicional utilizado pela PNPCT - "os espaços necessários à reprodução cultural, social e econômica dos povos e comunidades tradicionais, sejam eles utilizados de forma permanente ou temporária" - admite que "o espaço que nos interessa é o espaço humano ou espaço social" (SANTOS, 2008, p.151).

As demandas apresentadas retratam também a realidade encontrada em grande parte das comunidades 10 anos após o lançamento do Programa Brasil Quilombola e 4 anos após a criação do Plano Brasil Sem Miséria. Destaca-se o ganho de autonomia que as comunidades têm ganhado ao participarem desses encontros participativos e o seu conhecimento das políticas públicos e de seus direitos.

Suas demandas mostram que os Programas apresentam progresso na criação de institucionalidades importantes para a implementação de políticas públicas essenciais, em especial na criação dos espaços de participação social, na elaboração de importantes marcos legais e no fortalecimento de órgãos de coordenação de políticas transversais. Porém, ficou claro que o senso de justiça social dos quilombolas precisa ser melhor compreendido e seus valores respeitados na elaboração e implementação das políticas públicas.

Sen (2010, p. 349) afirma que

para a elaboração de políticas públicas é importante não apenas avaliar as exigências de justiça e o alcance dos valores ao se escolherem os objetivos e as prioridades da política pública, mas também compreender os valores do público em geral, incluindo seu senso de justiça. 


\subsection{PROGRAMAS E POLÍTICAS PÚBLICAS TRANSVERSAIS VOLTADOS PARA QUILOMBOLAS}

O Estado brasileiro apresentou avanços na gestão de políticas públicas sociais nos últimos anos ao reconhecer, primeiramente, a necessidade de promover a proteção e a inclusão social em conjunto com o desenvolvimento econômico e, em segundo lugar, ao focalizar as políticas públicas sociais aos mais pobres e vulneráveis deste país de modo a reduzir mais rapidamente as desigualdades de renda, de acesso a serviços, de moradia, de segurança, entre outros elementos considerados na análise da qualidade de vida e liberdade real das pessoas.

Desde 2003, foi implementado um conjunto de programas e políticas governamentais sob a coordenação de órgãos estrategicamente criados para assumir o protagonismo na coordenação de uma rede pública com objetivos em comum estabelecidos no plano de governo oficial do Estado nacional, o PPA. Ministérios da área social assumiram protagonismo na priorização de seus programas e políticas para territórios e segmentos populacionais em maior situação de vulnerabilidade no sentido de assegurar direitos individuais e sociais.

Em um movimento de territorialização das políticas públicas, rumo aos lugares, o Governo Federal avançou na articulação intersetorial com o fim de priorizar territórios considerados vulneráveis, como as periferias das metrópoles, a região do semiárido, os territórios étnicos, os territórios rurais, entre outros com grande concentração de pobreza.

Santos (2012, p. 84) considera que "nenhuma solução pode ser encontrada localmente, mas, sim, no quadro da estrutura socioeconômica e política total do Estado-Nação, ou seja, é uma formação socioeconômica integral". As diferenças espaciais de renda, portanto, é minimizada ou reduzida por meio da ação estatal sobre a redistribuição de renda e de consumo de serviços, infraestruturas e bens públicos. Porém a alteração da situação de pobreza estrutural implica um processo de "mudanças revolucionárias do ponto de organização da produção, da distribuição da riqueza e da própria organização do espaço" (SANTOS, 2012, p. 78).

A experiência dos últimos dez anos não necessariamente implica o desenvolvimento territorial. O que se vê é o esforço do Governo Federal de regionalizar e territorializar suas 
ações nas escalas estaduais e municipais. O desenvolvimento territorial em sentido estrito está relacionado a processos endógenos, nascidos nas regiões, nos lugares. Bacelar (2008, p. 26) destaca a importância da organização da sociedade local para promoção do desenvolvimento territorial:

Nesse tipo de experiência, o lugar que tem um elevado grau de organização da sociedade local consegue avançar mais rápido. É muito mais fácil fazer desenvolvimento territorial quando ele é aplicado a um lugar onde a sociedade está organizada. Está estruturada. Sabe para onde quer ir. Sabe se articular.

A articulação de políticas públicas e programas governamentais para a redução da concentração de renda e a desigualdade espacialmente construídas entrou no planejamento técnico-político, e a abordagem espacial ganhou penetração da abordagem de políticas tipicamente setoriais (BACELAR, 2008).

Um elemento essencial nesse processo de integração de agenda é a disponibilidade de informação homogênea a todos os atores sociais, o que só foi possível em certa medida devido à expansão, aprimoramento tecnológico, e reformulação do questionário do Cadastro Único para Programas Sociais do Governo Federal - CadÚnico ${ }^{19}$. Os dados obtidos por meio do preenchimento do formulário pelos municípios junto a potenciais beneficiários de políticas públicas reúnem cerca de 100 variáveis relacionadas aos indivíduos, aos domicílios e aos lugares de cerca de mais de 29 milhões de famílias, segundo dados do MDS de dezembro de 2014.

Os dados socioeconômicos do CadÚnico permitem o diagnóstico para formulação de políticas sociais em diferentes níveis: gênero, raça, cor, etnia, faixa etária, territorial, entre tantos outros. Portanto, disponibilizando o conhecimento da realidade social dos 5.570 municípios brasileiros, o CadÚnico se tornou a principal plataforma de informações para a seleção e gestão de programas como Bolsa Família, Água para Todos, Minha Casa Minha Vida, Tarifa Social de Energia Elétrica, Bolsa Verde e Telefone Popular, Cisternas, Programa de Aquisição de Alimentos.

\footnotetext{
${ }^{19} \mathrm{O}$ Cadastro Único é um instrumento de identificação e caracterização socioeconômica das famílias brasileiras de baixa renda: renda mensal igual ou inferior a $1 \frac{1}{2}$ salário mínimo por pessoa ou renda familiar total mensal de até três salários mínimos. A inclusão de famílias com renda total de até 3 salários mínimos mensais ocorreu para atender os Programas Habitacionais, como o Minha Casa Minha Vida.
} 
Além disso, é um importante instrumento de monitoramento do alcance da provisão de serviços básicos de saúde e educação, por meio do acompanhamento das condicionalidades do Programa Bolsa Família e de geração de renda, uma vez que os dados são atualizados a cada dois anos pelas famílias beneficiárias de Programas Sociais, em especial as beneficiárias do Programa Bolsa Família, sob pena de ter o benefício suspenso e posteriormente cancelado.

Assim, o Bolsa Família se constitui o principal programa do Governo para dar visibilidade à população pobre do país. A decisão de repassar o recurso diretamente às famílias por meio de um cartão bancário implicou a mobilização intensa do Governo Federal junto aos municípios para cadastramento de todas as famílias dentro do perfil de renda estabelecido.

Sem adentrar nos detalhes dos avanços conceituais, tecnológicos e federativos do desenho do Programa Bolsa Família, que não constitui o foco central deste trabalho, destacase que os resultados do Programa para a efetivação de uma política integral foram muitos.

O pagamento do Bolsa Família por meio de cartão direto às famílias utilizando o sistema bancário não só promoveu a inserção de muitas dessas famílias no sistema financeiro, como levou o sistema bancário a chegar a lugares antes esquecidos e deixados à margem. Hoje a Caixa Econômica está em todos os municípios brasileiros, chegando nas populações mais distantes, inclusive por meio de embarcações para atendimento das populações ribeirinhas na Região Norte.

A ênfase do Programa nas crianças, por meio das condicionalidades ${ }^{20}$ de saúde e educação, é estruturante para redução das desigualdades:

A transferência de renda voltada para população produtiva em idade ativa, com ênfase nas crianças, constituiu uma novidade na política social brasileira - e, de certa forma, começou a aproximar a estrutura de benefícios sociais do país da encontrada em países com sistemas de bem-estar social mais desenvolvidos. (PAIVA, FALCÃO e BARTHOLO, 2013, p. 25)

Mais importante, porém, foi o efeito indutor do Programa ao provimento local de serviços públicos de educação e saúde, em especial às crianças e gestantes, que têm que

\footnotetext{
${ }^{20}$ As famílias beneficiárias do Programa Bolsa Família devem cumprir condicionalidades de: educação (frequência escolar de $85 \%$ até 15 anos e $75 \%$ de 15 a 17 anos), saúde (acompanhamento do calendário vacinal e do crescimento e desenvolvimento nos postos de saúde para crianças até 7 anos; pré-natal para gestantes e acompanhamento de nutrizes) e assistência social (frequência de $85 \%$ no serviço de convivência e fortalecimento de vínculos nos Centros de Referência da Assistência Social- CRAS para crianças e adolescentes em situação de trabalho infantil).
} 
cumprir as condicionalidades do Programa para permanecer recebendo o recurso, e de assistência social, por meio do acompanhamento familiar e trabalho social com as famílias, resultando na expansão do Sistema Único de Assistência Social - SUAS a todos os municípios, fundamental para fortalecer a proteção social e o enfrentamento das vulnerabilidades.

A fim de atingir os objetivos da pesquisa, daremos foco na discussão das estratégias de focalização nos territórios quilombolas. Para o cadastramento de grupos populacionais específicos $^{21}$, incluindo alguns dos segmentos de Povos e Comunidades Tradicionais, e obter informações qualificadas sobre seus territórios, o Governo Federal somente progrediu depois da estratégia chamada de busca ativa, adotada pelo Plano Brasil Sem Miséria, que envolveu a pactuação intensiva com os entes federados no sentido de encontrar as pessoas mais pobres do país que estavam fora do Programa Bolsa Família.

As ações de busca ativa implementadas a partir de 2011 resultaram em um aumento de mais de $100 \%$ na cobertura de famílias quilombolas no Cadastro, que, em julho de 2011, havia registrado somente 59.333 famílias quilombolas desde 2003. Em dezembro de 2014, as famílias quilombolas inscritas no Cadastro somavam 131.787 famílias. Destas, 99.372 eram beneficiárias do Programa Bolsa Família. Em quatro anos, cadastrou-se mais quilombolas do que o total conseguido em oito anos.

Estima-se, porém, que esse número não representa todas as famílias quilombolas inscritas no CadÚnico, uma vez que a aplicação do formulário com a introdução de campos que indagam diretamente se a família é quilombola e o nome da comunidade a que pertencem somente foram introduzidas em 2010. Assim, muitas famílias quilombolas podem ter sido cadastradas no período anterior sem a correta identificação.

Apesar da subcobertura do CadÚnico para famílias quilombolas no Brasil - o caderno “Programa Brasil Quilombola Diagnóstico de Ações Realizadas" estimava a existência de cerca de 214 mil famílias ${ }^{22}$ quilombolas, o Cadastro é o principal instrumento de diagnóstico

\footnotetext{
21 Indígenas, quilombolas, famílias em situação de rua, ciganos, extrativistas, pescadores artesanais, pertencentes a comunidades de terreiro, ribeirinhos, agricultores familiares, assentados da reforma agrária, beneficiários do Programa Nacional de Crédito Fundiário, acampados, atingidos por empreendimentos de infraestrutura, presos dos sistema carcerário, catadores de material reciclável.

22 Cálculo estimado a partir da média de famílias das comunidades certificadas (1.834), acrescida da previsão das comunidades em processo de certificação (377) e das famílias das comunidades tituladas que não são certificadas (114). A média de pessoas por família, 5,5, foi baseada na Chamada Nutricional Quilombola (2006). (BRASIL, 2012)
} 
e localização das famílias remanescentes de quilombo, tendo sido a base para os programas que compõem o Programa Brasil Quilombola - PBQ e o Brasil Sem Miséria - BSM.

O PBQ, lançado em março de 2004 pelo Presidente Lula na Comunidade Engenho II do Território Kalunga, marca a primeira ação estatal no sentido de alcançar o território quilombola por meio de um agrupamento de programas e recorte orçamentário dos diversos ministérios. Como desdobramento, instituiu-se em 2007 a Agenda Social Quilombola - ASQ com o fim de garantir (Brasil, 2012): 1) titulação da terra, requisito para acesso a oportunidades de desenvolvimento territorial; 2) infraestrutura e qualidade de vida, por meio da provisão dos serviços públicos básicos e essenciais de fornecimento de energia elétrica, saneamento, saúde, educação, comunicação, vias de acesso, entre outros; 3) inclusão produtiva e desenvolvimento local, com base em políticas de desenvolvimento sustentável, preservando a identidade da comunidade e a sustentabilidade ambiental, ao mesmo tempo que promove a autonomia econômica e produtiva; e, 4) direitos e cidadania, de modo a garantir a participação social e política das comunidades quilombolas nos espaços de decisão e implementação de ações públicas.

Coordenado pela SEPPIR, a gestão dos programas que compõe o PBQ em nível federal se dá por um conjunto de 11 órgãos, que compõem o Comitê Gestor do PBQ. Em nível local, coube aos Estados formarem Comitês Estaduais a fim de se articularem com as associações representativas das comunidades quilombolas e com os órgãos estaduais e municipais de promoção da igualdade racial.

Porém, somente cinco estados possuíam Comitê Estadual no ano de 2013, segundo o Relatório de Gestão do Programa (Brasil, 2013), entre eles o Estado de Goiás. Para suprir a ausência destes, a SEPPIR, juntamente com o Comitê Gestor Nacional, promoveu os Seminários de Ações Integradas do PBQ com o fim de consolidar Planos Estaduais de Ações Integradas do Programa, com metas físicas e financeiras, cronograma de aplicação, responsabilidades definidas e prazos de execução. Para a consolidação dos Planos, é necessário que os estados assinem Termo de Cooperação com o Governo Federal. No entanto, até novembro de 2014, somente sete estados o fizeram (Arantes; Martins; Flit, 2014).

Esse fato evidencia que a questão quilombola entrou na agenda política do Governo Federal, mas este ainda precisa fomentar a sua incorporação nas agendas municipais e 
estaduais, que não necessariamente têm interesse em promover ações de promoção dessas comunidades. Castro (1997, p. 33) destaca os antagonismos de interesses inerentes ao pacto federativo brasileiro:

O pacto federativo é, por definição, um pacto de base territorial, no qual grupos localizados organizam-se em busca da harmonização entre suas demandas particulares e os interesses gerais. Há, portanto, uma constante tensão nesse pacto, cabendo aos arranjos institucionais acomodar estes interesses e controlar os conflitos.

O fundamento de que o Estado tem soberania sobre seu território muitas vezes é contraditório às perspectivas locais de governo descentralizado. Assim, o caminho da política pública advinda de uma decisão política da União encontra percalços entre grupos da sociedade, grupos políticos e entre entes federados. Muitas vezes, o poder de influência de representantes do Governo Federal ou os recursos financeiros repassados para governos locais é que vão garantir o sucesso de uma política pública, conforme Castro (1997, p. 35) afirma que:

as consequências do processo decisório, quando se trata de estudar a distribuição de poder entre os diversos grupos da sociedade, apontam para uma problemática do poder de influência e dos recursos, nele mobilizados, para a análise dos processos de tomada de decisão.

Castro (1997) destaca que o pacto federativo acomoda interesses sociais territorializados, mas as demandas para sua efetivação são complexas, resultando no não atendimento de grande parte das necessidades sociais. As estruturas administrativas criadas

para gestão das atribuições de cada uma das três esferas de poder, que constituem três escalas territoriais diferenciadas - a nacional, estadual e municipal, também não garantiu eficiência e adequabilidade entre os problemas e os aparatos institucionais para sua administração. (CASTRO, 1997, p. 37)

A escala federativa proposta vislumbra que os municípios atenderiam as demandas locais, por terem maior visibilidade dos problemas, os estados seriam os mediadores entre essas demandas e o seu conjunto territorial estadual e o Governo Federal daria as diretrizes para a unidade do território nacional. Porém, esse esquema “[...] pressupõe uma racionalidade em que haja coerência entre os supostos das demandas sociais e a funcionalidade do aparato político-administrativo para encaminhá-las [...]” (CASTRO, 1997, p. 38).

A distribuição de recursos entre os entes federativos foi redefinida na Constituição Federal de 1988 de forma a dar mais poder decisório no nível local. Porém, as competências e 
responsabilidades dos entes federal e estaduais não foram igualmente redistribuídas. Castro (1997, p. 41) cita alguns dos problemas acarretados para as escalas federal e estadual:

As crises nas áreas da saúde e da educação são em parte creditadas à perda de recursos e manutenção destes encargos no governo central. O nível estadual, por sua vez, sem poder contar com a fonte financeira da União para projetos de desenvolvimento, começa a desenvolver uma política agressiva e competitiva de atrair investimentos externos através de uma 'guerra fiscal', ou seja, elevados níveis de renúncia fiscal, cujos efeitos perniciosos ainda estão sendo conhecidos e avaliados.

Destarte, a capacidade de coordenação de políticas sociais em nível federal foi diminuída. Uma vez que os entes federados têm autonomia política e financeira, estados e municípios criam agendas sociais próprias (ARRETCHE, 2004). Seus efeitos, sem negar a importância de governos locais terem independência para alocar recursos, podem ser percebidos na quantidade de ações sobrepostas e às vezes dispersas no território nacional.

Arretche (2004, p. 22) destaca que "a forma como estão estruturadas as relações federativas nas políticas específicas afeta as estratégias possíveis para coordenação vertical das políticas nacionais". Assim, a adesão dos entes federados a políticas setoriais depende muito da disposição de instrumentos e recursos institucionais de cada política para influenciar as agendas locais.

Portanto, ao pensar uma política de abrangência nacional, o Governo Federal deve contar com sua capacidade de indução em nível local. A instituição de espaços de negociação e pactuação política, de representação estadual e municipal nas tomadas de decisões, e de participação popular, como é o caso de conselhos e conferências, favorece a adesão de governos estaduais e municipais.

No exemplo das políticas de saúde e de assistência social, em que o Governo Federal tem a autoridade de normatizar, financiar e coordenar as relações intergovernamentais por meio de Comissões Tripartites e Bipartites, há maiores chances de adesão em todo o território nacional. Porém, não garante a igualdade de atendimento, pois a capacidade de gestão de gastos dos governos subnacionais é uma grande condicionante para a implementação das políticas, conforme discorrido por Arretche (2004, p. 25):

A constitucionalização de encargos ou níveis de gasto é, entretanto, uma estratégia que encontra limites nas desigualdades horizontais da federação brasileira. A desigualdade horizontal dos governos subnacionais permanece recomendando cautela na definição constitucional de competências exclusivas na gestão das políticas sociais, ainda que a descentralização fiscal 
e de políticas tenha aumentado as capacidades estatais - administrativas, fiscalizadoras e de produção de serviços - dos governos subnacionais. A vinculação de gasto tende ainda a reproduzir no plano da implementação das políticas desigualdades preexistentes de capacidade de gasto.

Portanto, a previsão de recursos orçamentários no nível federal, embora seja de grande relevância, só se tornará efetiva se a coordenação federal contar com espaços de negociação e participação dos entes federados e dos beneficiários nos processos decisórios com uma efetiva política de indução do interesse do poder local. No entanto, reconhecemos que a dotação orçamentária é um grande passo rumo à implementação de uma agenda.

A questão quilombola somente veio ter visibilidade no orçamento público no ano de 2004. O PPA 2004-2007 estabeleceu entre os 31 desafios governamentais "promover a redução das desigualdades raciais, com ênfase na valorização cultural das etnias”, porém esse desafio foi resumido em apenas dois programas: "Gestão da Política de Igualdade Racial” e "Brasil Quilombola".

Em que pese o reconhecido esforço de consolidar a agenda racial e étnica como área de ação governamental, o volume de recursos alocados para a gestão da política de igualdade racial tem sido residual em relação ao orçamento das políticas sociais da União.

Theodoro (2008), em livro publicado pelo IPEA sobre as políticas de desigualdade racial no Brasil em comemoração aos 120 anos da abolição, destaca que apesar de a criação da SEPPIR ter sido um significativo avanço no Governo Federal, o escasso orçamento e a pouca prioridade do governo retrata que as políticas públicas de promoção da igualdade racial ainda tem caráter residual.

A análise dos dados consolidados do exercício orçamentário do ano de 2005
demonstra que, de um lado, houve uma alocação de recursos residual para
fazer frente ao desafio. Em que pese o esforço oficial de consolidação da
temática racial como área de ação governamental, a Gestão da Política de
Igualdade Racial recebeu algo em torno de R $\$ 20$ milhões, um volume de
recursos bastante reduzido para aquele que seria o principal instrumento de
ação com o objetivo de redução das desigualdades raciais. (THEODORO,
2008, p.170)

Theodoro (2008, p. 170) ainda destaca que o PBQ sofreu expressivas limitações financeiras, exemplificando que, em 2005, de todos os 92 programas sociais definidos no PPA, o PBQ sofreu o maior corte orçamentário, "tendo sido empenhados apenas $34,4 \%$ do total de recursos inicialmente autorizados, enquanto a média geral manteve-se em torno de $97,3 \% "$. 
De fato, a SEPPIR não foi desenhada para ser um órgão de grande execução orçamentária, pois a sua missão é de coordenação intersetorial, já que se trata de uma política transversal. O desafio da SEPPIR, como núcleo coordenador e articulador da igualdade racial, é grande, pois deve lograr o envolvimento e sensibilização dos gestores dos ministérios executores das principais políticas de acesso a direitos como o da saúde, do desenvolvimento social, da educação, das cidades e desenvolvimento agrário para que estes aloquem recursos para as comunidades quilombolas no Brasil.

Jaccoud (2008, p. 159-160) destaca que a promoção de uma política transversal

Pressupõe ainda a elaboração de uma estratégia ampla, ao mesmo tempo em que exige uma grande capacidade de negociação e sensibilização, de modo a integrar objetivos e organismos. A transversalidade depende da mobilização de instituições, agentes públicos para a incorporação da perspectiva da igualdade racial, sem que isso implique no deslocamento dos objetivos específicos e missão de cada uma das políticas públicas envolvidas.

Em 2011, com a posse da Presidente Dilma Rousseff, o Governo Federal lançou o Programa Brasil Sem Miséria- BSM, com o objetivo de erradicar a extrema pobreza no Brasil.

Considerando que, segundo dados do Cadastro Único, dezembro de 2014, as famílias quilombolas inscritas no Cadastro somavam 131.787 famílias, e que destas, 99.372 eram beneficiárias do Programa Bolsa Família, correspondente a $75 \%$ das famílias quilombolas, estavam abaixo da linha de pobreza, o BSM constitui também importante objeto de análise para o alcance dos objetivos deste estudo.

O BSM é organizado em três eixos: 1) garantia de renda para alívio imediato da situação de extrema pobreza; 2) inclusão produtiva para qualificação profissional e geração de oportunidades de acesso a renda no meio urbano e rural; e, 3) acesso a serviços públicos, induzindo o atendimento prioritário aos segmentos mais vulneráveis.

Neste trabalho, trataremos apenas das ações de inclusão produtiva e geração de renda no meio rural, uma vez que é o local onde as comunidades quilombolas se concentram, em sua maior parte.

O primeiro eixo visava aumentar a renda familiar das famílias em situação de pobreza. A transferência de renda para as famílias identificadas no Cadastro com renda inferior à linha de extrema pobreza adotada pelo Programa - $\mathrm{R} \$ 70$ foi a forma mais rápida e eficaz encontrada. Assim, foram realizados ajustes no valor pago às famílias, expandidos os 
benefícios para todas as crianças e adolescentes das famílias, e iniciados pagamentos adicionais para gestantes e bebês em fase de amamentação.

De acordo com Osorio e Soares (2014), de 2003 a 2011, a efetividade do Programa na superação da linha de extrema pobreza somente alcançava aquelas famílias cuja renda per capita familiar era próxima a $\mathrm{R} \$ 70$. O Programa não conseguia resgatar da pobreza justamente as famílias com menor renda, em especial as famílias maiores. Por isso, em 2012, a lógica de pagamento do Bolsa Família modificou-se de forma radical com a introdução de um benefício extra dentro do Programa - Benefício para Superação da Extrema Pobreza variável de acordo com a intensidade da pobreza da família - de modo que a renda da família supere o patamar de R 70 per capita. Osório e Soares (2014, p. 755) avaliam que

Percebe-se que a criação do Benefício para Superação da Extrema Pobreza tornou o Programa Bolsa Família mais pró-pobre, pois a maior parte dos recursos adicionados ao Programa, de 2011 em diante, foi dirigida às famílias de renda declarada mais baixa.

Como o Governo Federal apostou fortemente na transferência de renda aos mais pobres do país, foi necessário pensar estratégias para encontrar e cadastrar aqueles que não eram beneficiários do Programa. Assumindo que a população localizada em territórios mais vulneráveis - povos e comunidades tradicionais, moradores de rua, e população rural em geral - nem sequer estavam cadastrados para acesso aos diversos programas sociais, em especial ao Bolsa Família, o Governo Federal procurou pactuar com os estados e municípios para encontrar e cadastrar essas famílias, a chamada busca ativa.

Para isso, a assistência social fortaleceu-se por meio da constituição das chamadas Equipes Volantes nos Centros de Referência da Assistência Social- CRAS ${ }^{23}$, que deveriam se deslocar em busca das famílias mais vulneráveis no território. Para campanhas de cadastro, foram mobilizados também os agentes de saúde do Ministério da Saúde, os agentes

\footnotetext{
23 O CRAS é o lugar que possibilita, em geral, o primeiro acesso das famílias aos direitos socioassistenciais e, portanto, à proteção social. Estrutura-se, assim, como porta de entrada dos usuários da política de assistência social para a rede de Proteção Básica e referência para encaminhamentos à Proteção Especial. Desempenha papel central no território onde se localiza ao constituir a principal estrutura física local, cujo espaço físico deve ser compatível com o trabalho social com famílias que vivem no seu território de abrangência e conta com uma equipe profissional de referência. É no CRAS que o SUAS Sistema Único da Assistência Social integra os serviços e benefícios da Proteção Social Básica, que têm como objetivo a prevenção de situações de risco por meio do desenvolvimento de potencialidades e aquisições e o fortalecimento de vínculos familiares e comunitários. Destina-se à população que vive em situação de fragilidade decorrente da pobreza, ausência de renda, acesso precário ou nulo aos serviços públicos ou fragilização de vínculos afetivos (discriminações etárias, étnicas, de gênero ou por deficiências, dentre outras). Fonte: http://www.mds.gov.br/assistenciasocial/protecaobasica
} 
ambientais do Meio Ambiente e os técnicos do INCRA, sem desconsiderar a autonomia dos municípios para desenvolver estratégias locais.

No site do MDS é reconhecido que "pertencimento a populações tradicionais que habitam áreas isoladas ou distantes, pertencimento a segmentos socialmente excluídos, desconhecimento de seus direitos, entre outros, dificultam o acesso dessas famílias aos programas sociais municipais, estaduais e Federais". Portanto, o Governo Federal desenvolveu linhas de financiamento no sentido de permitir aos municípios comprar veículos e lanchas com o objetivo de chegar nos territórios marginalizados.

De acordo com o Censo Demográfico do IBGE, em 2010, somente 15,6\% dos brasileiros viviam no meio rural. Porém, $47 \%$ dos extremamente pobres do país moravam em territórios rurais. Assim, não só era preciso levar políticas sociais como transferência de renda, educação e saúde, como aprimorar a política voltada para segurança alimentar e agricultura familiar de modo a alcançar os agricultores familiares, assentados, acampados, extrativistas, pescadores, quilombolas, indígenas, entre outros.

De acordo com Campos et al. (2014), as ações de inclusão produtiva rural no BSM contemplavam desde ações de infraestrutura básica - acesso à água e à energia elétrica - a medidas de apoio à estruturação da produção e à comercialização. Campos et al. consideram que a articulação entre a assistência técnica e o repasse de recursos não reembolsáveis para fomentar a estrutura produtiva de agricultores em extrema pobreza permitiu mudanças não só na geração de renda como na produção de alimentos pelas famílias.

Uma das prioridades nesse eixo foi a promoção do acesso à água - Programa Água para Todos -, que consiste na implantação de tecnologias sociais variadas de captação de água da chuva para consumo, criação de pequenos animais e cultivo de "quintal produtivo".

Combinado com o acesso à água, o agricultor familiar em extrema pobreza recebe o apoio do serviço de assistência técnica - Ater associado ao recurso de $\mathrm{R} \$ 2.400$ por família, que deve estar registrada no CadÚnico, para investimento em projeto produtivo. A família recebe o recurso diretamente do Governo Federal por meio do cartão Bolsa Família, privilegiando as mulheres do campo. Campos et al. (2014) reforça a relevância do Programa de Fomento às Atividades Produtivas Rurais para a promoção da segurança alimentar, geração de renda - por meio da comercialização de excedentes, e para o "reencontro com a identidade de agricultor". 
O Programa de Aquisição de Alimentos -PAA, criado em 2003 para utilizar o poder de compra do Estado para apoiar agricultores, fortalecer e ampliar circuitos de comercialização (Campos et. al., 2014), foi aprimorado e simplificado por meio da Lei $\mathrm{N}^{\circ} 12.512 / 2011$ e do Decreto $N^{\circ} 7.775 / 2012$, que, dispensando a celebração de convênio e a contrapartida pelo estado ou município, passou a fazer o pagamento do benefício diretamente do Governo Federal aos agricultores familiares por meio de cartão bancário. $\mathrm{O}$ termo de adesão ao Programa do estado ou município estimula o estabelecimento de metas de produção orgânica e de participação de mulheres. Órgãos públicos federais, estaduais e municipais - como universidades, escolas, hospitais e presídios, por exemplo - passaram a ter dispensa de licitação se a demanda de alimentos em seu âmbito for atendida por produtos da agricultura familiar.

Ainda no eixo das ações de territorialização da inclusão produtiva, o Estado brasileiro conta com ações do Programa Garantia-Safra, microcrédito do Pronaf - Programa Nacional da Agricultura Familiar e apoio à organização econômica. Campos et. al (2014, p. 464) coloca o atendimento a agricultores de povos e comunidades tradicionais como desafio:

Outro desafio que se impõe é a ampliação do atendimento a povos indígenas, comunidades quilombolas e outros povos e comunidades tradicionais. Os esforços no sentido de adequar os instrumentos de políticas públicas devem ser ampliados e inovações devem ser buscadas tendo-se em conta as especificidades linguísticas e culturais.

A articulação das políticas públicas de inclusão produtiva rural com as demais políticas públicas de desenvolvimento territorial devem avançar no sentido de permitir que os povos e comunidades tradicionais, além de outras populações rurais específicas, permaneçam em seus territórios.

Por meio das estratégias de política pública descritas acima, a primeira voltada para um território étnico e para a promoção da igualdade social e a outra voltada para o combate à extrema pobreza, o Governo brasileiro procura formar redes de coordenação para uma ação coletiva e harmônica em busca da eficiência e eficácia de seus programas.

Porém, o alcance de metas e objetivos complexos requer uma ação igualmente complexa que põe em jogo interesses políticos, expectativa popular, alta carga de trabalho e responsabilidade para a administração pública em todas as esferas federativas, operações e decisões conflitivas, levando em consideração que 
Los errores de diseño y los defectos de implementación son más comunes, obviamente, en las políticas sociales que enfrentan problemas cuyos componentes y factores explicativos arraigan en realidades vitales de difícil acceso e incidencia gubernamental (VILLANUEVA, 1993, p.17).

A decisão do Governo Federal pelo alinhamento de múltiplos atores no desenho e implementação de políticas públicas parte de princípios de conhecimento comum sobre organização do trabalho em equipe. Quanto mais articulados e coordenados estiverem os agentes, políticos ou técnicos, mais eficiente será a administração pública.

Brugué (2008, p. 9) destaca que "para poder oferecer respuestas conjuntas a problemas complejos debemos ser capaces de recuperar la política y el diálogo o, si se prefiere, la política entendida como diálogo". Esse diálogo requer a integração inter e intragovernamental, a parceria público-privada e, principalmente, a estreita relação com as associações e organizações da sociedade civil, a fim de permitir a participação social dos beneficiários da política, articulando o que Brugué chama de racionalidade deliberativa, no lugar da racionalidade tecnocrática.

Somando e complementando a política como diálogo, destaca-se que não só os resultados da política como seu processo de implementação devem ter avaliação tangível para auxiliar na tomada de decisões, na correção de rumos e melhoria na articulação intersetorial, popular e entre níveis de governo.

O PBQ e o BSM propõem o trabalho em rede com múltiplos atores que atuam tanto na tomada de decisões como na execução das ações. O primeiro é coordenado pela Secretaria Especial de Políticas para a Igualdade Racial-SEPPIR e o segundo pelo Ministério do Desenvolvimento Social e Combate à Fome- MDS. A articulação continuada com todos os ministérios permite a transferência de recursos entre instituições para se alcançar os objetivos comuns.

No primeiro caso, o Governo Federal decidiu por criar uma secretaria especial com status de ministério no âmbito da Presidência da República a fim de que aquela tivesse um caráter articulador, com relativa hierarquia junto aos ministérios executores, mas com pouca autonomia de recursos. No segundo, o Governo decidiu que um ministério setorial, com maior autonomia de recursos, mas sem hierarquia junto aos outros ministérios - por não estar vinculado ao órgão central -, atuasse como o principal órgão articulador e coordenador de uma política transversal. 
No lugar de comparar a coordenação ou a efetividade de ambas as redes, iremos discorrer sobre formas diferentes de coordenação de políticas públicas transversais. Em ambos os casos a confiança no trabalho entre todos os parceiros envolvidos é essencial para negociação e acordo das regras e da definição de papéis.

A literatura sugere a tipologia de três tipos de transversalidade: 1) corrente principal (mainstream), que condiciona e orienta o trabalho de toda a estrutura organizativa do estado, como é o caso do BSM, prioridade governamental da Presidente da República; 2) estratégias corporativas, que pretendem mudar a forma de trabalhar de toda uma organização, como é o caso da introdução da participação popular nas decisões de políticas públicas; e, 3) grupo populacional, que pretende focalizar as políticas a um grupo coletivo concreto, como é o caso do PBQ. Por fim, as políticas transversais de corrente principal e de grupo populacional são consideradas substantivas e aquelas de estratégias corporativas são instrumentais.

O PBQ e o BSM possuem instâncias deliberativas de grande importância para desenvolvimento da confiança mútua, para a pactuação continuada dos objetivos a serem atingidos e para o monitoramento e avaliação de ambas políticas transversais. Esses espaços de deliberação conjunta devem permitir uma negociação ampla, inclusive de recursos, e de diálogo solidário entre os membros da rede, a fim de permitir que todas as instituições se sintam parte do processo e do compartilhamento de resultados.

Outro ponto de grande importância é a prioridade política dos objetivos de uma política transversal como é o caso do PBQ e do BSM. O PBQ, criado na gestão do Presidente Lula, teve maior prioridade de agenda a partir da criação da Agenda Social Quilombola em 2007, que impulsionou uma rede intersetorial dentro do Governo Federal, coordenada pela SEPPIR e Casa Civil, para sua formulação. O Comitê de Gestão da Agenda Social Quilombola é composto por técnicos da Casa Civil e dos ministérios do Desenvolvimento Agrário, da Cultura, do Desenvolvimento Social e Combate à Fome, de Minas e Energia, da Saúde, da Educação, da Integração Nacional, dos Transportes e das Cidades.

Já o BSM foi tratado com prioridade na primeira gestão de governo da Presidente Dilma, uma vez que seu discurso de vitória eleitoral declarou o fim da extrema pobreza como sua principal meta. O BSM foi beneficiado por uma rede de alto nível governamental para sua formulação, gestão e monitoramento.

Para compor sua estrutura de governança, foram formadas instâncias interministeriais: 
um Comitê Gestor Nacional, formado pelos ministros do MDS, Casa Civil, Fazenda e Planejamento; um Comitê Executivo, formado pelos secretários executivos dos ministérios listados; e um Grupo Interministerial de Acompanhamento, que envolveu a Secretária Geral da Presidência e ministérios das Cidades, Trabalho e Emprego, Desenvolvimento Agrário, Educação, Saúde e Integração Nacional. Assim, no caso do BSM, questões de grande relevância como orçamento e alterações legais eram tratadas diretamente pelos ministros dos órgãos tomadores de decisão.

Ainda no sentido de ampliar a governança, dentro do MDS, foi criada uma secretaria extraordinária somente para coordenação da estratégia em nível interno - entre as demais secretarias - e externo - entre entes federados, sociedade civil e demais ministérios parceiros.

Uma das grandes vantagens do MDS para exercer seu papel de coordenação do BSM em relação à SEPPIR na coordenação do PBQ é que a Secretaria de Orçamento Federal criou um marca orçamentária que identificou todas as ações voltadas para o BSM no orçamento da União, sendo possível conhecer o orçamento federal total destinado ao BSM. Além disso, o MDS não só é o ministério coordenador do BSM como também o executor da maior parte dos recursos orçamentários destinados ao Programa. Dos R \$ 115 bilhões dotados para o BSM nos orçamentos de 2011 a 2014, com execução de 95\%, considerando os recursos empenhados e $88 \%$, considerando somente os recursos liquidados, R\$ 108 bilhões foram alocados no MDS, sendo que este executou $96 \%$, considerando os empenhos, e $92 \%$, considerando os liquidados.

Já o orçamento total destinado ao PBQ e à Agenda Social Quilombola- ASQ, bem como sua execução, é desconhecido, uma vez que não há uma marca nos orçamentos dos ministérios para o Programa. Como resultado, o Acórdão $\mathrm{N}^{\circ}$ 2771/2014 do Tribunal de Contas da União- TCU recomendou à SEPPIR que publique os dados relativos à execução orçamentária das ações previstas para a ASQ e para o Sistema de Monitoramento do PBQ e que divulgue a relação das ações orçamentárias previstas no PPA 2012-2015 para comunidades quilombolas, além de ter recomendado ao Comité gestor da ASQ que:

9.2.1. estabeleça mecanismos que assegurem apresentação dos dados orçamentários e financeiros pelos órgãos executores para todas as ações, específicas e de caráter universal, da agenda quilombola;

9.2.2. adotem mecanismos e instrumentos institucionalizados de coordenação, com vistas a formulação, implementação e monitoramento da Agenda Social Quilombola - ASQ, que possibilitem a atuação conjunta das partes interessadas no desenvolvimento das ações integrantes dessa política pública transversal; 
Apesar de ser possível identificar trinta e uma ações voltadas para comunidades quilombolas e outros públicos tradicionais no PPA 2012-2015, apenas cinco são exclusivamente para comunidades quilombolas. Além disso, o PBQ nem aparece no atual PPA com o nome Programa Brasil Quilombola. "O fato de o PBQ não estar citado fragiliza as articulações interministeriais e o monitoramento do Programa" (ARANTES; MARTINS; FLIT, 2014, p. 173).

Além de não haver a marcação do Programa no orçamento, a maior parte das políticas públicas também não tem dados específicos de atendimento à população quilombola em seus bancos de dados. Portanto, outro desafio apontado por Arantes, Martins e Flit (2014) na coordenação do Programa é a escassa produção de indicadores voltados para a população quilombola, já que os dados dos grandes institutos de pesquisa ainda separam a população somente em rural e urbano, homens e mulheres, brancos e negros.

No último Censo, em 2010, o IBGE acrescentou polígonos de territórios indígenas, o que tem permitido avançar nas pesquisas para esses territórios. Nesse sentido, a SEPPIR firmou Termo de Cooperação com o IBGE para que sejam criados setores censitários exclusivos para os quilombos já titulados, e atua em Grupo de Trabalho coordenado pela Secretaria Geral da Presidência para que o Censo Agropecuário decenal incorpore dados específicos em seu questionário que ajudem na produção de indicadores dos territórios quilombolas.

Os maiores líderes das redes do PBQ e o BSM têm sido a própria figura de Presidente da República, que, tanto Lula quanto Dilma, já afirmaram em eventos públicos simbólicos a sua predisposição para a remoção de obstáculos e enfrentamento de resistências que possam dificultar a implementação dos planos de superação da pobreza extrema, com maior frequência e intensidade, e de igualdade racial.

Por outro lado, os desafios quanto à forma de organização estatal que permita a gestão descentralizada e a parceria entre entes federativos e com organizações sociais estão postos. Os recursos desses Programas estão centralizados no Governo Federal, que definiu a prioridade governamental e conta com a parceria dos estados e municípios para a implementação efetiva das ações planejadas. Porém, os instrumentos burocráticos e administrativos que permitem a transferência de recursos, como por exemplo convênios e editais, precisam de modernização para permitir eficácia. 
[...]transformações recentes no papel do Estado e em suas relações com a sociedade impõem novos modelos de gestão que comportem a interação de estruturas descentralizadas e modalidades inovadoras de parcerias entre entes estatais e organizações estatais ou sociais. (FLEURY, 2007, p. 9)

Um exemplo de boa prática na transferência de recursos entre entes é a modalidade de transferência fundo a fundo realizada pelas políticas de saúde, educação e assistência social. Ainda assim, quando o recurso chega ao município, este encontra dificuldades de execução devido aos processos burocráticos autofágicos de licitação para aquisição de bens e serviços e contratação, por exemplo.

Outro exemplo de obstáculos criados pela própria gestão pública para a consecução de seus objetivos de promover a igualdade de direitos é a complexidade do processo de regularização de terras no Brasil, tratado no capítulo 1.

O PBQ tem como ponto de partida o direito constitucional dos remanescentes de quilombos à terra, porém os entraves políticos e burocráticos para a regularização do território quilombola ainda são o maior gargalo dessa política transversal que pretende levar o direito ao crédito rural, ao acesso ao Programa de Aquisição de Alimentos e à agua, entre tantos outros direitos. Muitos desses direitos são impossibilitados pelo fato de a comunidade não possuir o título da terra e pelas forças antagônicas criadas localmente, que se aproveitam do moroso processo de regularização. Ou seja, é o Estado a mercê de jogos de poder e conflitos de grupos de interesses polarizados.

Nesse contexto, vale a pena destacar a grande relevância que o poder local ganha num processo de gestão descentralizada da política pública transversal ao ser o responsável por articular uma rede social que promova o diálogo entre atores públicos e privados em um determinado espaço geográfico, coletivizando ideias e buscando alternativas para a solução de problemas que são próprios de um determinado território.

"Quando se fala em território deve-se, pois, de logo, entender que se está falando em território usado, utilizado por uma dada população" (SANTOS, 2012b, p. 97). De forma proativa e autônoma o gestor local tem o papel central de promover a participação social dos beneficiários e de maximizar a utilização dos recursos disponíveis, sendo sua atuação, inclusive, decisiva para o sucesso ou fracasso da política pública transversal no território.

Portanto, no momento da elaboração ou coordenação da implementação de políticas públicas, o poder local deve ser colocado em primeiro plano, pois 
O papel regulador das funções locais tende a escapar, parcialmente ou no todo, menos ou mais, ao que ainda se poderia chamar de sociedade local, para cair nas mãos de centros de decisão longínquos e estranhos às finalidades próprias da sociedade local. (SANTOS, 2012a, p. 25)

Tumelero (2011) sugere a criação de desenhos administrativos-jurídicos de gestão municipal que levem em conta órgãos executivos territorializados; espera-se que tais órgãos operem sob estratégias participativas de decisão e que possam atuar sob a perspectiva territorial articulados a órgãos setoriais, visando ampliar o acesso à informação, os processos de gestão da política transversal com enfoque territorial e a participação social. E, ainda que mantidos os conselhos sociais setoriais, como os conselhos de assistência social e de saúde, entre outros, sugere que sejam viabilizados espaços de gestão de políticas transversais voltadas para o território. Essa lógica viabilizaria a participação popular com uma visão da totalidade do espaço, permitindo a abordagem integral das demandas de política pública territorial.

A dinâmica espacial e os complexos desafios territoriais exigem respostas racionais, conciliadoras e integrais a seus problemas. O Estado deve ser capaz de compreender a totalidade dos territórios vulneráveis, em especial aqueles pertencentes a povos e comunidades tradicionais, evitando a superposição e as lacunas por meio de um sistema de ação voltado especificamente para os sistemas de objetos de um determinado território. Em outras palavras, tomar como referência para as políticas públicas o conceito de espaço central de Santos (2002) como um conjunto indissociável de sistema de ações e sistema de objetos é fundamental para uma política pública espacial que resulte em desenvolvimento e expansão das liberdades substantivas.

O Estado brasileiro ousou ao colocar a erradicação da fome e a superação da extrema pobreza como metas prioritárias de Governo, mas para enfrentar o desafio de promover uma política igualitária é preciso modificar as estruturas econômicas, sociais e políticas, indo além da redistribuição de renda. "[...] nenhuma política econômica, inclusive a nova repartição dos excedentes, obterá sucesso sem o estabelecimento paralelo de uma política espacial. As duas políticas são indissociáveis" (SANTOS, 2012, p. 81).

Ciente de que a revolução das estruturas econômicas proposta por Santos ainda não foi o objetivo maior do Estado brasileiro no período de referência deste trabalho, este trabalho discutirá no capítulo 3 de que maneira as inovações na articulação e integração de políticas 
sociais trouxeram efeitos no desenvolvimento como liberdade dos quilombolas, tendo como referência a comunidade Kalunga.

No próximo capítulo, serão relatadas a pesquisa de campo e a reflexão dos Kalunga sobre o alcance ou não das políticas públicas em seu território, sobre os possíveis efeitos da presença e da ausência de políticas públicas essenciais na melhoria de suas condições de vida e na transformação do espaço - considerando que houve uma tentativa do Estado brasileiro de remover as maiores fontes de privação de liberdades substantivas das comunidades quilombolas como a pobreza e suas consequências: a fome, a desnutrição, o analfabetismo e a doença. 


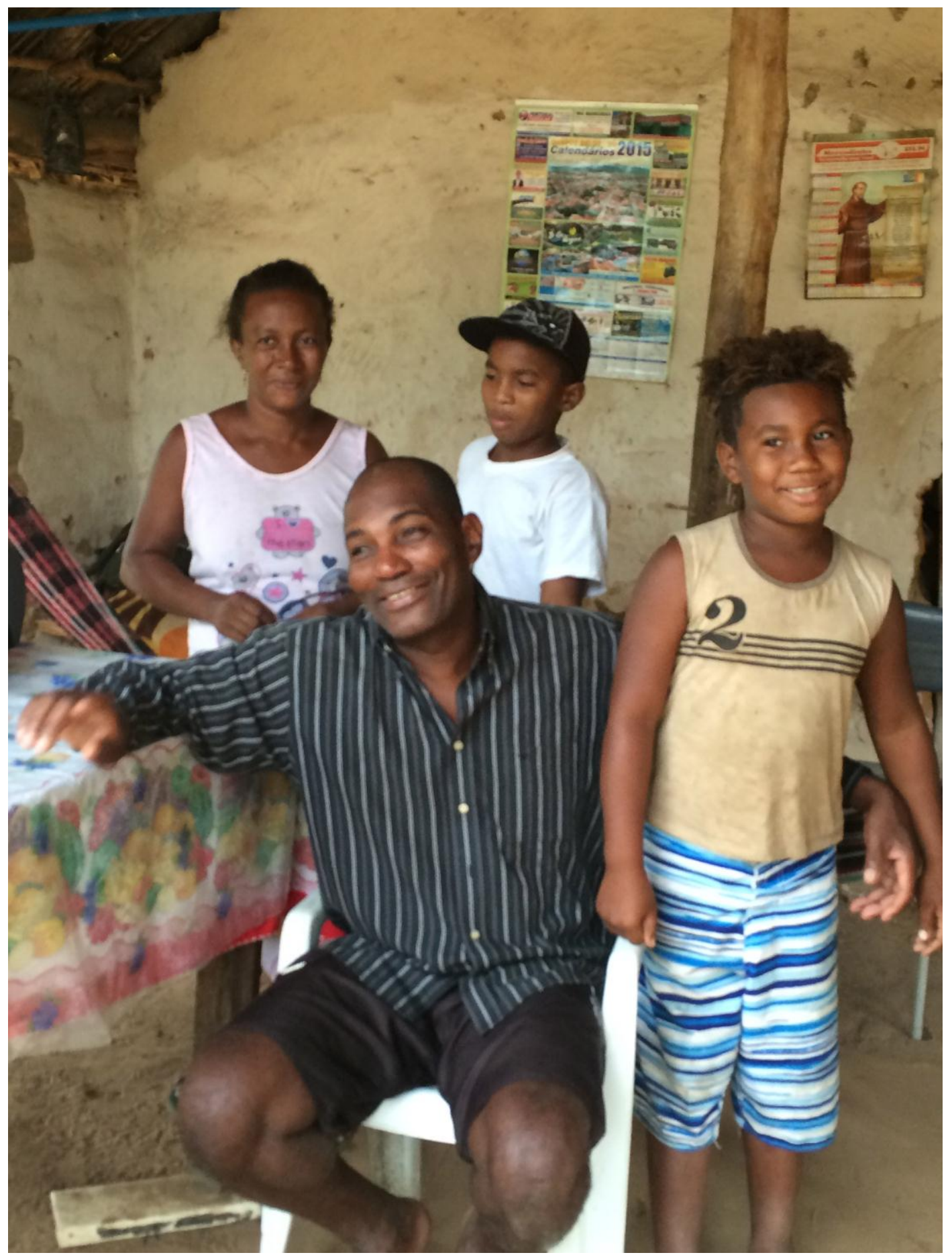

“Aqui tá uma coisa muito difícil. O pessoal tomou medo dos outros. Muita gente entrou aqui prometendo coisas, pegando assinatura dos Kalunga e ficou rico moiando a mão no dinheiro de projeto usando o nome dos Kalunga. [...] Tem muita verba aqui pro Goiás mas aqui num chega”.

Seu Zezinho, 45 anos, e Dona Titinha, 40 anos, 6 filhos 


\section{CAPÍTULO 3}

\section{VOZ E LIBERDADE KALUNGA}

Quando foi pensando o projeto desta pesquisa, entre o final de 2012 e o início de 2013, esta pesquisadora ainda não tinha a informação de que o MDS lançaria os resultados de uma Pesquisa de Segurança Alimentar e Nutricional, cuja pesquisa de campo teria se realizado em 2011 por meio da aplicação de um questionário com informações socioeconômicas em todos os domicílios das comunidades tituladas, e que estas incluiriam a Comunidade Kalunga.

Era sabido que seria necessário realizar uma pesquisa de campo para conhecer a realidade socioespacial Kalunga a fim de averiguar se as políticas públicas haviam alcançado o seu território. Os primeiros questionários pensados eram semiestruturados com perguntas a respeito da qualidade dos domicílios, da renda auferida pelas famílias, incluindo benefícios assistenciais, da escolaridade dos membros familiares, em especial das crianças, do acesso a serviços de saúde, em especial o pré-natal e a vacinação infantil, entre outros.

Em meados de 2013, o MDS lançou o resultado da pesquisa. A felicidade desta pesquisadora em obter as informações nacionais, regionalizadas e localizadas de todos as comunidades quilombolas tituladas do Brasil foi imensurável, e ainda maior quando o Departamento de Avaliação da Secretaria de Avaliação e Gestão da Informação do MDS nos disponibilizou a consolidação dos questionários aplicados na comunidade Kalunga. Pensamos de imediato que não mais seria necessário realizar a pesquisa de campo, pois os dados já haviam sido coletados.

No entanto, o pensamento de que seria importante dar voz aos Kalunga e viver, por curto tempo que fosse, a realidade vivida no lugar Kalunga não nos deixava. Era preciso ir para conhecer, para ver as paisagens do lugar, os elementos do espaço e as mudanças provocadas pela ação externa, a fim de reconhecer o mínimo possível a realidade de um dado momento, a situação geográfica, conforme conceituada por Santos (2014, p. 103):

Uma situação geográfica, ou seja, o que um lugar é, num determinado momento, sempre constitui o resultado de diversos elementos, que se dão em diferentes níveis. Esses elementos são variáveis, pois mudam de significação através do tempo. 
Portanto, para compreender de que maneira a introdução de políticas sociais trouxeram efeitos no desenvolvimento como liberdade dos quilombolas, tendo como referência a comunidade Kalunga, concluímos que não só seria necessário analisar os dados oficiais retratados pela Pesquisa do MDS como também observar o lugar e o cotidiano dos Kalunga, além de, por meio das conversas, ouvi-los e lhes dar voz a fim de dar sentido ao contexto geográfico.

Nesse sentido, uma pesquisa de campo com base na etnografia nos daria a oportunidade de realizar o esforço intelectual necessário para realizar uma descrição mais elaborada da realidade que se pretendia apreender. Para isso, seria preciso "[...]estabelecer relações, selecionar informantes, transcrever textos, levantar genealogias, mapear campos, manter um diário, e assim por diante" (GEERTZ, 2008, p. 4). Técnicas e procedimentos etnográficos nos permitiriam compreender o "movimento da totalidade", conforme Santos descreve o espaço geográfico.

Ressalta-se que utilizar a metodologia de campo da pesquisa etnográfica como base para as entrevistas realizadas não implica nenhuma tentativa de realizar um estudo antropológico, pois a antropologia não estuda o lugar e sim no lugar, conforme GEERTZ (2008, p. 16) descreve:

O lócus do estudo não é o objeto de estudo. Os antropólogos não estudam as aldeias (tribos, cidades, vizinhanças...), eles estudam nas aldeias. Você pode estudar diferentes coisas em diferentes locais, e algumas coisas - por exemplo, o que a dominação colonial faz às estruturas estabelecidas de expectativa moral - podem ser melhor estudadas em localidades isoladas. Isso não faz do lugar o que você está estudando.

Optou-se por realizar entrevistas aprofundadas, dado que o número de entrevistados não tinha mais tanta importância, uma vez que os dados quantitativos já haviam sido disponibilizados pela Pesquisa do MDS. A interação e a aproximação com os Kalunga ganhou maior relevância já que o que se pretendia era compreender o que as políticas públicas significavam para eles e observar seus efeitos, quando elas estavam presentes ou quando estavam ausentes.

A interação social começava já no sorriso aberto dos Kalunga ao receber esta pesquisadora em suas casas, principalmente no Vão de Almas e no Vão do Moleque, que, por serem mais distantes e não receberem tantas pessoas "de fora" quanto no Engenho II, onde os 
moradores ficavam sempre atentos quando o carro chegava, e, mesmo sem saber ainda o motivo da minha "visita", abriam um grande sorriso para me receber.

No lugar de solicitar uma entrevista, esta pesquisadora sempre usou o termo "conversa", pois a dinâmica era realmente a de um diálogo, sem prancheta e sem questionários. O objetivo da pesquisa era relatado logo de início a fim de manter o foco da conversa, que seguia um roteiro escrito no caderno de anotações desta pesquisadora, sem muita rigidez quanto ao seu seguimento. O que importava era que os entrevistados sentissemse livres para discorrer sobre os pontos que mais lhe afetavam devido à presença ou à ausência de políticas públicas no território.

Após cerca de dez minutos de conversa mais solta a fim de "quebrar o gelo", eu solicitava permissão para gravar, com cuidado para não enrijecer o diálogo: "Posso gravar para não esquecer? Não quero perder tempo escrevendo agora..." O interessante é que quase todos sempre diziam que sim, pois eles não negavam o que eles diziam. Esse sempre foi o momento mais tenso, mas o caráter dialógico tentou ser mantido ao máximo.

Todas as entrevistas foram gravadas como meio de registro adicional às notas tomadas no diário de campo. Apesar de a escrita do diário ter se dado preferencialmente no mesmo dia da realização da entrevista, o áudio foi essencial. A tomada de notas me permitiu anotar informações importantes sobre o ambiente, reações do pesquisado e de pessoas próximas e suas intervenções, mesmo que silenciosas. Porém, o áudio proveu um rico material de uso de linguagem, de raciocínio e consciência política, que somente sua repetida audição permite perceber a trajetória e a experiência de sujeitos concretos.

Sobre o local das entrevistas, a grande maioria se deu na casa dos entrevistados, onde eles estavam tranquilos e sem pressa de horário. Isso permitiu que a conversa partisse de observações realizadas pela pesquisadora em relação à sua própria casa (se a casa era de alvenaria, no modelo do programa habitacional popular, se tinham sido realizadas reformas, se havia água encanada ou energia elétrica, entre outros pontos), assim as conversas fluíram mais livremente.

Todas as entrevistas realizadas fora da residência do entrevistado também tiveram sua importância, a exemplo da entrevista realizada com uma Kalunga, Rita, que exerce a atividade 
de guia turística, principal atividade dos Kalunga do Engenho II para geração de renda. A entrevista se deu na trilha e na Cachoeira Santa Bárbara, principal atrativo turístico do município de Cavalcante, e que fica dentro do território Kalunga. A estratégia de contratar seu serviço de guia e posteriormente obter a sua permissão para realizar uma entrevista foi de grande importância não só para observação do lugar e da principal atividade laboral dos Kalunga do Engenho II, mas também para ter o dia inteiro para conversar com a entrevistada em um ambiente em que ninguém a observava e que ninguém nos ouvia.

O fato de o tema central ser as políticas públicas articuladas para os territórios quilombolas levou os entrevistados a depositarem certa esperança de que esta pesquisadora poderia ter respostas para suas questões ou mesmo solução para os maiores gargalos em relação ao desenvolvimento de seu território. Em todos os casos que isso foi percebido, a condução dada foi a de esclarecer o lugar do pesquisador e reapresentar o objetivo da pesquisa, claro que reafirmando minha disposição para tentar entender conjuntamente questões incompreendidas e para dar visibilidade para as questões postas por eles no texto.

Em relação ao tempo dedicado ao campo, foram realizadas três viagens de cinco dias ao município de Cavalcante, de onde esta pesquisadora se deslocava para as grandes comunidades quilombolas do território Kalunga dentro desse município: Engenho II, Vão do Moleque e Vão de Almas.

Embora seja conhecido que uma permanência mais prolongada dentro da comunidade permitiria o maior aprofundamento da percepção da relação entre sujeitos, entendemos que a metodologia utilizada favoreceu o alcance de nossos objetivos, otimizando o tempo em campo com conversas intensivas com pessoas estrategicamente escolhidas.

Esta pesquisadora considerou fortemente os conselhos de Beaud e Weber (2007) em seu "Guia de Pesquisa de Campo: produzir e analisar dados etnográficos". A interação social nos bancos das portas das casas, na beira de um fogão de lenha, na mesa da cozinha ou na trilha da cachoeira, permitiu de fato uma aproximação sem intimidar os entrevistados, com linguagem simples e compreensível, olho no olho, e sem formalismos de pesquisas, como questionários e fornecimento de dados. 
O guia de Beaud e Weber não fornece receita de entrevista, mas aponta estratégias para se ganhar a confiança do entrevistado. “(...) conseguir rapidamente compreender o que está sendo dito (a meia-palavra) e entrar (temporariamente) em seu universo (mental)" (Beaud; Weber, 2007, p.134) foram os meios de interagir e alimentar o diálogo de maneira que a discussão fluísse de modo natural.

O primeiro contato realizado foi com a liderança das comunidades Kalunga do município de Cavalcante, Seu Cirilo. Já era de meu conhecimento, por meio da leitura de dissertações recentes sobre os Kalunga, por meio das reuniões dentro do Governo Federal com comunidades quilombolas e por meio de conversa com a Professora Maria Geralda da Universidade Federal de Goiás, que Seu Cirilo, tendo sido Presidente da Associação Quilombo Kalunga por mais de 12 anos, também devido a sua liderança natural, é uma pessoa importante na trajetória da comunidade Kalunga.

A partir da entrevista com ele, as outras entrevistas ganharam ritmo. Pode-se dizer que a pesquisa seguiu um rumo próprio. Com base no princípio da arborescência, ao final de cada entrevista, com o gravador já desligado, pedia-se conselho sobre quem poderia contribuir com a pesquisa. Todos entrevistados foram muito cooperativos e pareciam querer ajudar para que a pesquisa de campo tivesse sucesso.

O campo foi intensivo, por ter muitas recomendações de pessoas para entrevistar. Porém, com base na etnografia, esta pesquisadora teve que fazer escolhas e optar por conversas mais aprofundadas com pessoas estratégicas, que conhecessem as políticas públicas, que tivessem experiência de trabalho e liderança na comunidade, ou que tivessem vivência suficiente para saber falar do antes e do depois da introdução das políticas públicas no território.

Renunciar a algumas entrevistas não era fácil, pois a vontade era de conversar com todos que tinham algo a dizer, mas era necessário não só qualificar as entrevistas mas também ter fontes diferenciadas: homens e mulheres, mães e avós, Kalunga do Engenho, Kalunga do Vão do Moleque e Kalunga do Vão de Almas, etc. Foi preciso também ter cuidado para não ser pega por lutas internas dentro da comunidade. Se a liderança fez uma crítica muito forte a determinado morador ou grupo, e eu precisava mantê-lo como aliado, eu preferi não penetrar no assunto e nem procurar o grupo antagônico, afinal o tema de minha pesquisa não seria 
beneficiado por essa atitude. A gama da pesquisa já estava bastante diversificada pelos grupos de pessoas que participaram.

Destarte, os ganhos em qualidade da pesquisa obtidos por meio das interações sociais vividas poderão ser verificados nos relatos que seguirão. A descrição dos relatos será sistematizada de acordo com os temas de políticas públicas pesquisados, realizando ao mesmo tempo o cotejamento com os dados obtidos pela Pesquisa do $\mathrm{MDS}^{24}$.

Ressalta-se, no entanto, que a Pesquisa do MDS foi censitária e abordou toda a comunidade Kalunga, envolvendo os três municípios - Monte Alegre, Teresina de Goiás e Cavalcante. Como a pesquisa de campo com base etnográfica não tem a intensão de generalizar, esta pesquisadora foi apenas a agrupamentos pertencentes ao município de Cavalcante - o Engenho II, por este povoado Kalunga ter sido o que mais recebeu as políticas públicas, o Vão do Moleque e o Vão de Almas, por serem os maiores em extensão territorial e em população. É relevante destacar que a comunidade Kalunga está localizada em sua maior parte no município de Cavalcante. Considerou-se que pesquisar agrupamentos dos três municípios implicaria fazer uma comparação entre poderes locais, o que pode ser o foco de um estudo posterior. O importante neste momento, considerou-se, era ouvir os Kalunga para apreender como as provisões públicas permitiam ou a falta delas restringia a liberdade que eles buscam

Por fim, poderão ser analisados os resultados da execução do PBQ e do BSM na transformação do espaço e no desenvolvimento, com expansão de capacidades, autonomia e liberdade dos Kalunga.

\footnotetext{
${ }^{24}$ A Pesquisa de Avaliação da Segurança Alimentar e Nutricional de Comunidades Quilombolas Tituladas realizada pela DATAUFF em 2011, sob contratação do Ministério do Desenvolvimento Social e Combate à Fome - MDS em parceria com o Programa das Nações Unidas para o Desenvolvimento - PNUD será chamada aqui de Pesquisa do MDS.
} 


\subsection{DEPOIS DISSO AÍ É SÓ A GENTE SE DESENVOLVENDO}

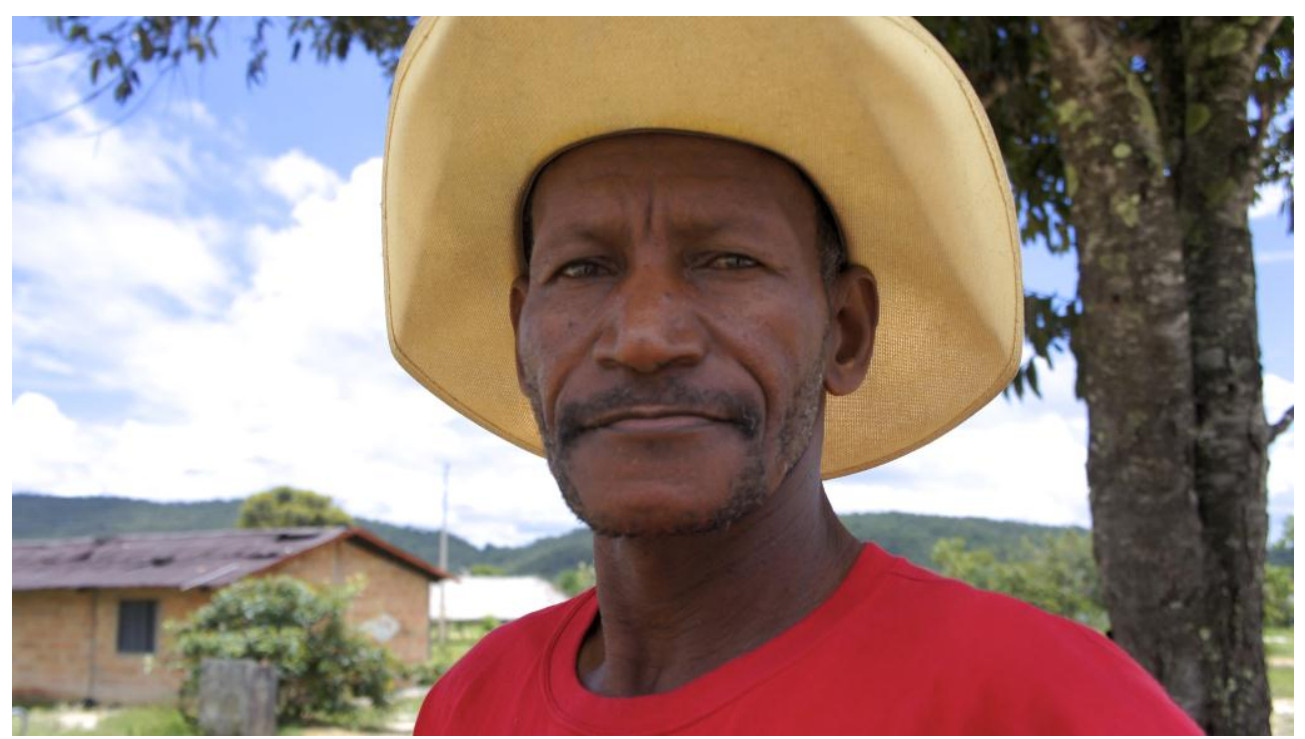

Figura 21: Seu Cirilo, Comunidade Engenho II, fev. 2015. Fonte: a autora.

Para os Kalunga, o reconhecimento da comunidade pelo Estado foi um grande marco na sua luta: "Depois disso aí é só a gente se desenvolvendo" (Seu Cirilo, liderança Kalunga). O reconhecimento de seu território representa o reconhecimento de sua história de vida, de sua identidade de luta e de pertencimento àquele lugar. Seu Cirilo (figura 21), homem de grande relevância na luta dos Kalunga, tendo sido a liderança da comunidade por mais de 12 anos, entende que os Kalunga passaram a ter voz junto aos governos e a serem vistos como sujeitos de direitos.

No entanto, algumas comunidades dentro do território tiveram maior desenvolvimento que outras. Os Kalunga pesquisados acreditam que a desigualdade entre os lugares é devida em grande parte à falta de vontade do poder público, a características geográficas de cada lugar e à capacidade de organização dos moradores.

A primeira comunidade visitada foi o Engenho II, a $37 \mathrm{~km}$ de Cavalcante, com estrada patrolada. Ao chegar no Engenho, percebe-se as casas de alvenaria com cobertura de telha e antenas parabólicas nos quintais e os postes de energia elétrica nas ruas. Já na entrada avistase o Centro de Atendimento aos Turistas e a loja de produtos sustentáveis Kalunga, ambos frutos de um projeto em parceria com a Petrobrás.

Seu Cirilo dos Santos Rosa, liderança Kalunga, conversou comigo em um dos restaurantes da comunidade, construído para receber os turistas que visitam as cachoeiras 
dentro do Sítio Histórico. Todo orgulhoso, e com razão, pois é um restaurante tipo varandona, agradável para qualquer turista que gosta de natureza. Falou livremente sobre a importância do restaurante para bem receber os turistas e de seu sonho de fazer um pousada para recebelos.

Seu Cirilo acredita que o apoio do SEBRAE - GO para desenvolvimento do turismo no território Kalunga também foi de grande relevância para o desenvolvimento do Engenho II. Relatou uma reunião em que estiveram ele e duas outras lideranças Kalunga, uma do município de Teresina e outro de Monte Alegre. O SEBRAE tinha a intensão de organizar o turismo e seus técnicos os consultaram quanto à possibilidade de abrir as cachoeiras do território para visitas. Ele e a representante das comunidades de Teresina, Esther, concordaram já que entenderam naquele momento que o turismo poderia trazer renda para a Comunidade. O representante das comunidades de Monte Alegre, por medo de que isso representasse a ida de pessoas de má fé que pudessem querer tomar suas terras, decidiu não abrir suas cachoeiras e rios para o turismo.

Seu Cirilo não se arrependeu. Acredita que foi um acerto, pois o turismo tem sido um grande vetor de desenvolvimento ao trazer renda para a comunidade Engenho II.

Perguntei a ele se os outras comunidades dentro do Sítio Histórico Kalunga estão tão organizadas quanto a do Engenho, e ele, já de início, com muita convicção, e certo ar de tristeza, disse que não, que no Território Kalunga, o povoado do Engenho II "foi o que mais se beneficiou do desenvolvimento" depois da titulação.

Acredita que o desenvolvimento de sua comunidade é devido à união de seus integrantes e da fé que eles têm em Deus. Falou da demarcação das terras do Território Kalunga pela Fundação Cultural Palmares, que primeiramente tinha deixado o povoado Engenho e uma parte do Vão de Almas de fora do sítio. Então Seu Cirilo, consciente da importância de sua participação política, foi até a Presidente da Palmares à época, Maria Dulce Pereira, que o recebeu e o ouviu, segundo seu relato. Ele e alguns companheiros do Engenho falaram de sua história com o território e da vinda de seus ancestrais, o que convenceu a Presidente da FCP a pedir que os técnicos voltassem ao Engenho para ouvir os moradores e redemarcassem o território incluindo o Engenho e o Vão de Almas tal qual ele hoje se configura. 
O marco central então foi a visita do Presidente Lula à comunidade em março de 2004, quando se deu o lançamento do Programa Brasil Quilombola. "Aí o desenvolvimento chegou mesmo". Segundo Seu Cirilo, a energia elétrica "chegou junto com o Presidente" e, em seguida, vários programas de desenvolvimento humano foram implementados na comunidade do Engenho II.

Seu Cirilo, por participar de muitas reuniões, seminários e encontros promovidos pelo Governo Federal, acredita que os quilombolas passaram a ter maior representatividade junto aos governos e a serem vistos como sujeitos de direitos. Além disso, acredita que até mesmo a população local de Cavalcante mudou no trato com os Kalunga. Ele fala, com certa emoção, que antes sofriam muito preconceito na cidade e que hoje eles são "tratados de outro jeito". Ele não foi muito específico sobre esse “outro jeito", mas pelo menos ele não sente que seja preconceito.

Dona Getúlia Moreira da Silva, 56 anos, mãe de 15 filhos, também moradora do Engenho II, acredita que as decisões da liderança e a persistência dos Kalunga do Engenho II trouxeram desenvolvimento para sua comunidade. Ela contou que, antes da titulação, a população do Engenho II vivia em casas mais dispersas. Quando foram informados que eles iriam receber as casas do programa de habitação, eles decidiram por fazer as casas mais aglomeradas: "O aglomeramento das casas foi melhor para o benefício da energia elétrica e da água encanada". Segundo ela, a comunidade ficou mais unida. Ela acredita que nas comunidades onde as casas são mais isoladas, longe umas das outras, é mais difícil chegar os benefícios.

Seu Joaquim Moreira da Silva, conhecido por Seu Mochila (figura 22), morador do Vão do Moleque, 70 anos, casado com Dona Iva, com quem tem 10 filhos, que não moram mais no território Kalunga, acredita que a vida melhorou muito depois que o território deles foi reconhecido como quilombola, porque os Kalunga hoje têm nome. Seu Mochila tem confiança na sua identidade e na força que as comunidades quilombolas ganharam nos últimos anos. "A Comunidade Kalunga é uma comunidade forte. Eu perdi as vistas (por causa de uma Catarata) e porque eu sou Kalunga eu fui o primeiro a ser atendido no Hospital de Base de Brasília. Agora eu tô enxergando.” 
Antes de começarmos a conversar, pedi a Seu Mochila permissão para gravar e para tirar uma foto dele. Ele pediu que eu aguardasse. Entrou em sua casa e colocou sua camisa de guia Kalunga. Uma camisa verde muito bonita com o nome QUILOMBO KALUNGA estampado. Muito orgulhoso de sua origem, Seu Mochila faz pose e deixa que eu o fotografe com sua camiseta.

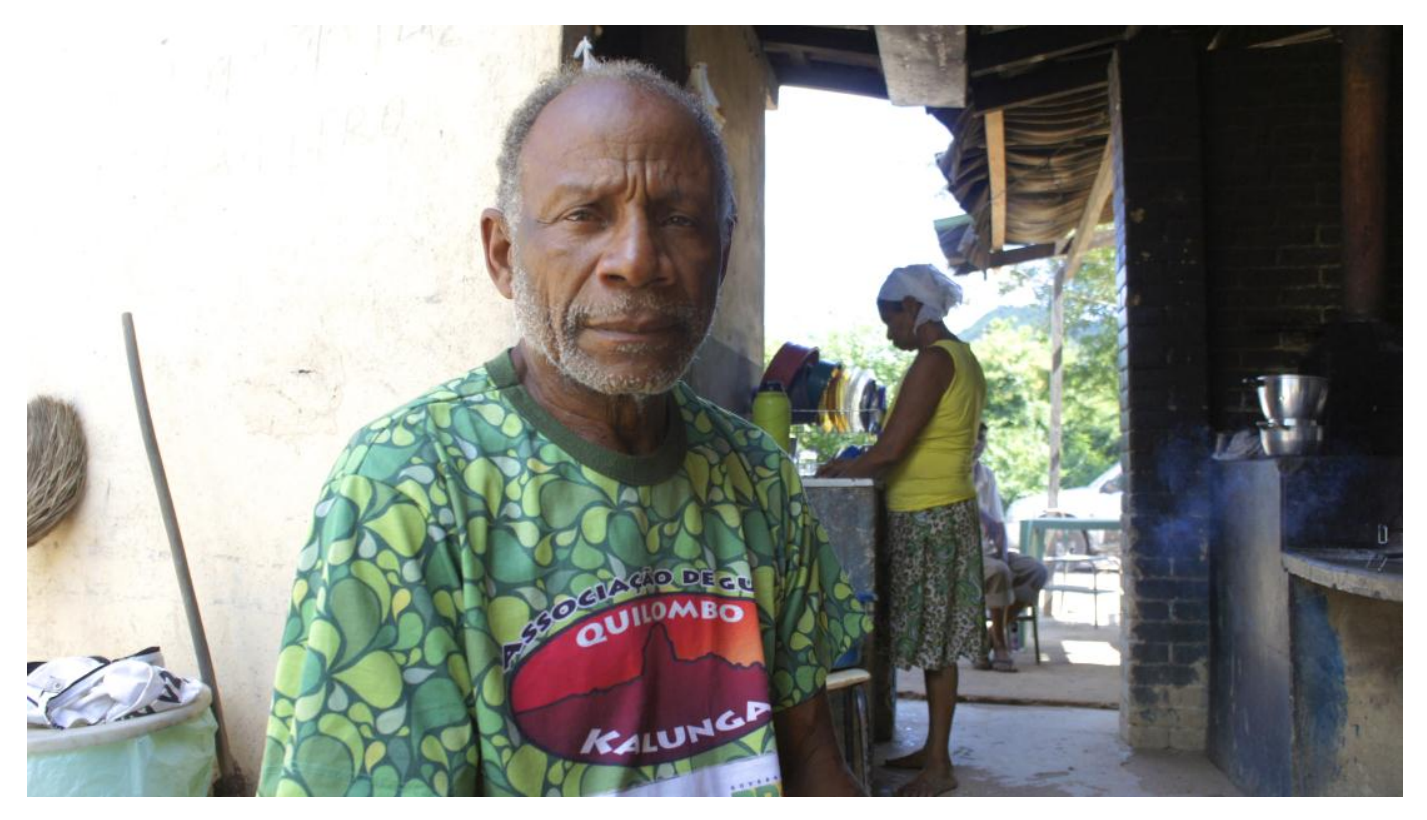

Figura 22: Seu Mochila, Comunidade do Vão do Moleque, fev. 2015. Fonte: a autora.

Aproveitando sua ida dentro de casa, Seu Mochila me trouxe uma revista de $2008 \mathrm{em}$ que ele aparece junto com Seu Cirilo na cerimônia de criação do Comitê Gestor das Comunidades Remanescentes de quilombos do Estado de Goiás (figura 24). A reportagem da revista dizia que uma das grandes conquistas dos Kalunga tinha sido a liberação pela Secretaria Estadual de Meio Ambiente e Recursos Hídricos -SEMARH para a construção de rodovias, obras de saneamento básico e eletrificação em meio rural no município de Cavalcante, que, segundo a revista, era uma demanda das populações quilombolas. Seu Mochila me mostra a reportagem com um pouco de cansaço e pergunta: "Será que vai chegar enquanto eu ainda estou vivo? As coisas têm que ser mais rápidas para eu poder ver." 


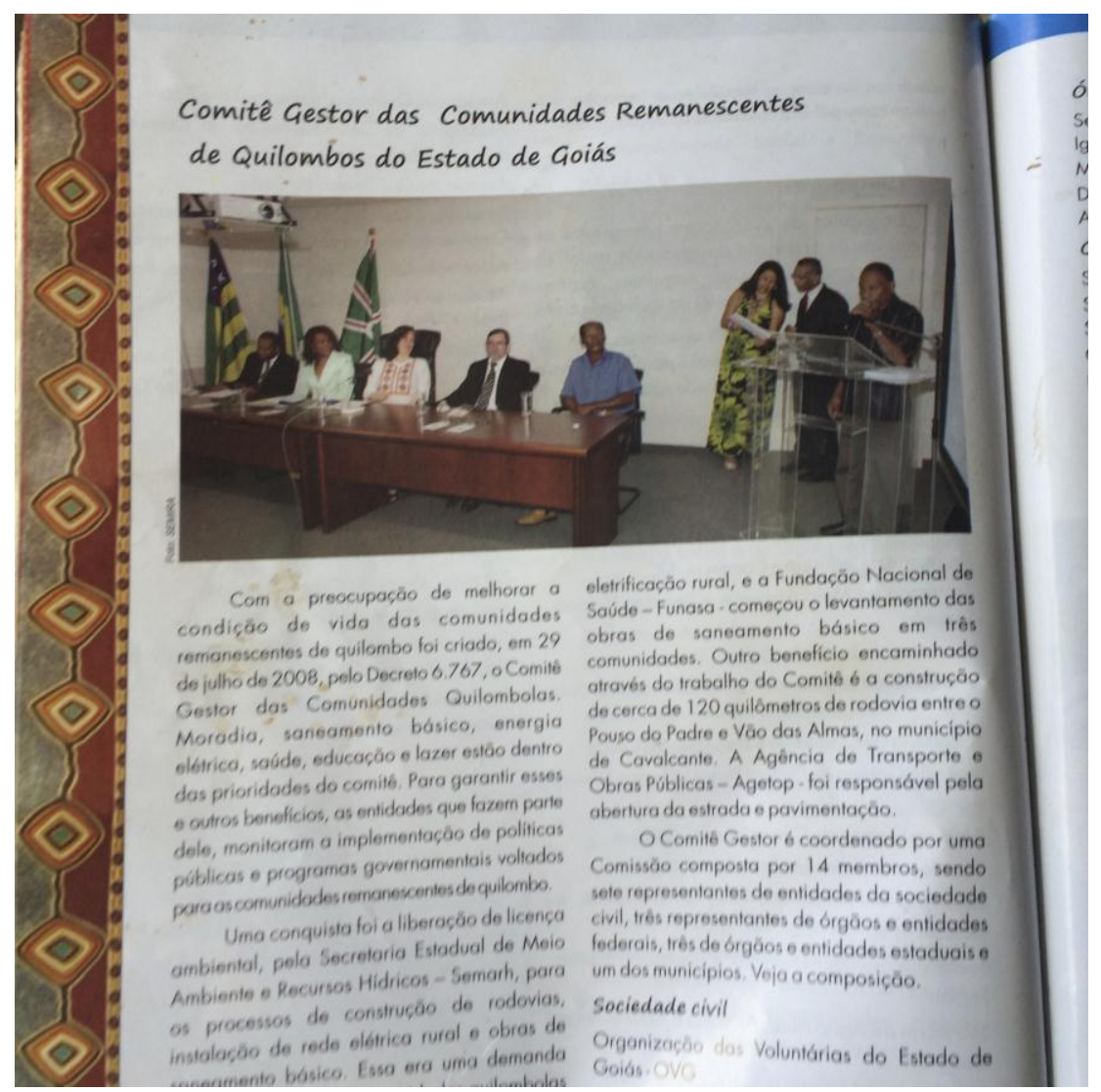

Figura 23: Reunião do Comitê Gestor das Comunidades Remanescentes de quilombos do Estado de Goiás em 2008. Fonte: a autora.

Dona Iva fica olhando atentamente outro livro que ele trouxe, feito pela Secretaria de Turismo do Goiás, sobre o Quilombo Kalunga, um livro muito bonito com fotos das paisagens e dos Kalunga. Eu olho para ela e digo: "Seu lugar é muito bonito". Ela sorri, mas não é de falar de muito, apenas folheia as páginas e me mostra outras fotos do livro, como quem diz "tem muito ainda que você não viu".

Porém, Seu Mochila entristece-se pela diferença de desenvolvimento entre o Engenho II e o Vão do Moleque, onde, "faltam estrada, energia elétrica, e, principalmente (fala em alto tom), posto de saúde". Segundo ele, são quase 500 famílias desamparadas pelo Estado. Ele credita a ausência de políticas públicas no Vão do Moleque à falta de capacidade de organização entre os moradores de lá. Ele destaca que "no Engenho, onde somente há cerca de 100 famílias, tem tudo, mas é por que eles são unidos”. Ele fala da importância de ter união entre os Kalunga do Vão do Moleque para que eles possam reivindicar e lutar pelos seus direitos. "A união é que faz a força e a força traz união". 
Seu Mochila não se conforma e quer lutar. Ele diz que vai fazer um ofício para pedir ajuda ao Governo Federal para construção da estrada. "Eu tenho amor na minha comunidade, e quando eu falo com um órgão, e ele diz que vai arrumar, eu pergunto 'é antes deu morrer?', eu falo brincando mas é sério, já esperamos muito".

Realmente os moradores do Vão do Moleque já esperaram muito por políticas públicas e relatam cansaço, falta de esperança e de fé no poder público. Dona Aimiram, cerca de 40 anos, 5 filhos, moradora do Vão do Moleque, relatou esforços de organização coletiva que eles têm empreendido no sentido de consertar a estrada que liga o Engenho II ao Vão do Moleque. Eles relaram ter se reunido com a ajuda da Associação Quilombo Kalunga, no ano de 2014, a fim de juntar dinheiro para pagar as horas de um trator que arrume a estrada em virtude da preparação da festa de Nossa Senhora do Livramento, que ocorre em setembro. Apesar de terem conseguido angariar muitos recursos, segundo ela, eles ainda estão devendo algumas horas para o dono do trator, que espera receber o recurso da Associação, que arrecada dinheiro na portaria do Engenho II, onde os turistas devem pagar R $\$ 10,00$ por pessoa para visitar duas cachoeiras.

Os moradores do Vão do Moleque estão novamente se organizando para consertar a estrada. Só que dessa vez, como não acreditam possuírem meios de arrecadar recursos novamente, eles pretendem consertar a estrada com a enxada em mutirão. Dona Aimiram ficará responsável por cozinhar junto com outras mulheres, e os homens trabalharão na obra. Cientes da importância das técnicas e da informação, eles pretendem filmar o mutirão e colocar nas redes sociais a fim de chamar atenção do poder público federal.

Apesar das dificuldades vividas dentro de seu território, o aumento da autoestima relatada por Seu Cirilo é percebido em muitos momentos da conversa. O Marido de Aimiram, Seu Manoel, é do Ceará e a conheceu em Brasília. Mora no Vão do Moleque há dois anos com ela. Disse com muito orgulho que agora é Kalunga, que não abre mão de ser Kalunga e de morar ali. Apesar de ter de sair de lá para trabalhar em obras por empreitada em Brasília ou Formosa, ele sempre volta para sua casa no Vão.

Eles falaram com muita empolgação de suas festas religiosas e de suas danças. Seu Manoel disse que é susseiro ${ }^{25}$, ao que Dona Aimiram dá uma grande gargalhada, pois ela diz

\footnotetext{
${ }^{25}$ Em referência à dança tradicional Kalunga sussa.
} 
que ele quer ser um deles de qualquer jeito. Ela me mostra suas roupas de dançar sussa com muito orgulho. Fala de todas as grandes susseiras e das apresentações que fazem nas festas dentro e fora do território. O orgulho de ser Kalunga, o amor ao lugar é percebido no brilho dos olhos de Dona Aimiram ao relatar todas as festas religiosas que os unem.

Rita Pereira Tartuliane, 44 anos, 8 filhos, sendo 7 vivos, é moradora do Engenho II, mas "foi nascida e criada no Vão do Moleque", em suas palavras. Rita casou-se com um Kalunga do Engenho II e decidiu viver lá. Ela diz que o Engenho é "o paraíso no meio do deserto".

Segundo Rita, "lá todo mundo é feliz porque ninguém lembra mais do sofrimento". Perguntei a ela por que ela achava que no Engenho II estava tão diferente, Rita credita isso à organização dos moradores do Engenho II para lutar por seus direitos e fala da importância da liderança representativa. Rita considera que foi a vontade de um líder de conhecer e buscar meios de levar as políticas públicas a sua comunidade que fez a grande diferença. "Aqui teve aquela pessoa que enxergou, teve aquela atitude de trazer algum benefício de melhor. Ele não quis só pra ele". Ela afirma que as lideranças lutaram por todas as comunidades, não só pelo Engenho. Porém, a que foi mais beneficiada foi o Engenho, segundo ela, devido à persistência de Seu Cirilo.

Ela acredita que se houvesse uma pessoa dentro do Vão do Moleque para "seguir com persistência na luta”, hoje o Vão estaria na mesma condição de qualidade de vida. Ela diz que Seu Cirilo "era sozinho na sua luta, que no Vão do Moleque não tem liderança". Ela afirma que os moradores do Vão de Almas e do Vão do Moleque criticam o fato de só o Engenho ter recebido as políticas, mas que ela viu, depois que foi morar no Engenho, que faltou liderança no Vão, faltou coletividade para lutar por seus direitos.

Rita não desconsidera o fato de haver duas cachoeiras nos arredores do Engenho II, além de sua proximidade da cidade ter contribuído para organizar o turismo e, consequentemente, trazer benfeitorias. Ela acha que os Kalunga ganharam "fama" depois da titulação, e muitos turistas vão ao Engenho II para conhecer a cachoeira e para conhecer a comunidade quilombola. Os Kalunga do Engenho II receberam projetos de apoio ao desenvolvimento do turismo e políticas que permitiram estruturar essa organização, como a estrada, a energia, a água, e isso, segunda ela, "foi o que melhor pôde acontecer no Engenho". 
Segundo ela, todos conseguem alguma renda por meio de seu trabalho, seja do artesanato, seja da cozinha, seja do serviço de guia. No entanto, ela acredita que outras comunidades Kalunga poderiam também ter organização para o turismo e políticas de infraestrutura se lutassem por seus direitos.

No que concerne à participação social e representação serão temas tratados mais detalhadamente adiante. O importante neste ponto é destacar que a titulação trouxe aos Kalunga entrevistados a consciência de seus direitos e, para alguns lugares mais e outros menos benefícios de provisão pública. Porém a diferença entre os benefícios recebidos é vista pelos entrevistados como uma falha da sua própria organização para buscar os meios de ter a política pública implantada.

Tendo consciência de que o Estado deve suprir toda a população com infraestrutura e serviços públicos básicos, os Kalunga do Engenho II mostraram sua insatisfação com os governos, principalmente local e estadual, perante à situação dos outros povoados que ainda não tiveram aceso às políticas públicas, em especial de acesso a estrada, transporte, energia elétrica, assistência médica e água.

Seu Albertino Bispo da Cunha, 75 anos, morador do Vão de Almas, também percebe que houve melhoras depois da titulação: "Tá miorando mais. Ave Maria se tivesse naquele tempo. Até sopro de saúde o povo aqui agora num é mais doente”. Ele diz que o maior benefício foi a estrada (de chão) aberta há cerca de cinco anos para o Vão de Almas: "Depois que abriu a estrada, toda muie que tá gestante, quando tá na hora de ganhar menino, alguém liga e o carro vem buscar na hora."

Já José Moreira dos Santos, conhecido por Seu Zezinho, 45 anos, morador do Vão de Almas, acredita que a titulação da terra não trouxe benefícios, pois não chegaram as políticas públicas prometidas, e eles não podem vender as terras para se capitalizar. "Se vendesse uns 3 alqueires, a gente podia comprar um lote na cidade para pôr os meninos para estudar, para comprar uma placa solar". Quando perguntei a ele se não seria ruim a presença de pessoas de fora, que não são Kalunga, no território, caso ele vendesse, ele disse que não. "Ia era ajudar a gente, porque podia contratar a gente para trabalhar. Aqui é todo mundo pobre." 
A pesquisa do MDS na comunidade Kalunga investigou o efeito da titulação na comunidade em relação a: acesso a programas governamentais, infraestrutura, alimentação, acesso a renda e crédito, mobilização e participação política, fortalecimento da identidade negra e quilombola, disputa por terras, e preconceito e agressões sofridas.

A questão sobre titulação foi feita apenas a lideranças, no caso da comunidade Kalunga foram quatro entrevistados, envolvendo comunidades dos três municípios.

Das quatro lideranças entrevistadas, todas acreditavam que o acesso a políticas públicas e programas governamentais de saúde, educação e assistência social aumentou ou aumentou muito. Já quanto ao acesso a políticas de infraestrutura, somente um disse ter aumentado, a metade afirmou não ter mudado nada, enquanto outro acredita que até diminuiu.

O melhor resultado foi quanto à alimentação. Todos afirmaram ter aumentado a quantidade da alimentação, sendo que três deles disseram ter melhorado inclusive a qualidade, o que deve ter relação com a acesso a renda, crédito ou projetos comunitários, em que três afirmaram ter melhorado.

Conforme percebido nas conversas com os Kalunga, a pesquisa do MDS relata que todos concordaram que a identidade deles como quilombola se fortaleceu e três lideranças relataram acreditar que a capacidade deles de mobilização e participação política aumentou ou aumentou muito, mas um afirmou ter diminuído.

A maioria, três deles, afirmaram ter diminuído a situação antes sofrida por eles de agressão, preconceito ou discriminação, apesar de somente dois terem afirmado que disputas por terra com proprietários rurais diminuíram e somente dois afirmaram ter acesso livre a todo território devido à presença de ocupantes não quilombolas no território, como fazendeiros.

O fato de hoje eles terem a titulação da terra não teve grande impacto sobre suas atividades produtivas agropecuárias, pois somente duas lideranças afirmaram ter aumentado as plantações, criação de animais, beneficiamento de produtos, cooperativismo ou atividade de preservação ambiental.

Pode-se verificar portanto que tanto o trabalho de campo desta pesquisa como a pesquisa do MDS identificaram que o maior ganho da titulação da terra e o reconhecimento 
da comunidade quilombola foi o fortalecimento de sua identidade e o usufruto a programas de acesso a renda, como Bolsa Família e aposentadoria, que parecem ter relação com a maior disponibilidade de alimentos nas famílias.

Nota-se também que a titulação não teve efeitos homogêneos em todo o território, destacando-se a desigualdade de acesso a infraestrutura, em especial água, energia elétrica, estrada e transporte, que serão tratados separadamente mais adiante, dada sua relevância para aumentar o bem estar e a capacidade dos Kalunga de gerar renda. 


\subsection{NOSSA SAÚDE, NOSSA EDUCAÇÃO, NOSSO DESENVOLVIMENTO EM GERAL ESTÁ RELACIONADO À ESTRADA.}

Em três dias de pesquisa no Engenho II, falou-se muito sobre a precariedade da estrada para o Vão do Moleque. Há dois caminhos, um percurso "por fora" de $140 \mathrm{~km}$ de estrada em condição razoável de passar de caminhão ou caminhonete. Porém, por esse caminho é preciso atravessar o Rio Corrente, que tem cerca de $100 \mathrm{~m}$ de largura e não tem ponte $^{26}$. Assim, em época de chuva não é possível atravessar. O percurso "por dentro" (figura 24), que foi o que seguimos, é um grande atalho de somente $65 \mathrm{~km}$ descendo a serra do Engenho II até o Vão do Moleque, mas essa "estrada" nunca foi patrolada.

A estrada foi aberta pelos próprios Kalunga por meio de arrecadação de recursos individuais para pagar diárias de um trator de esteira. Atravessa-se cerca de 15 córregos chegou um momento que parei de contar - cheios de pedras grandes (figuras 25 e 26), em um caminho íngreme, cheio de valas, de pedras, e declives imensos. Levamos $3 \mathrm{~h} 30$ para percorrer os 65 km de estrada de chão e chegar ao Vão.

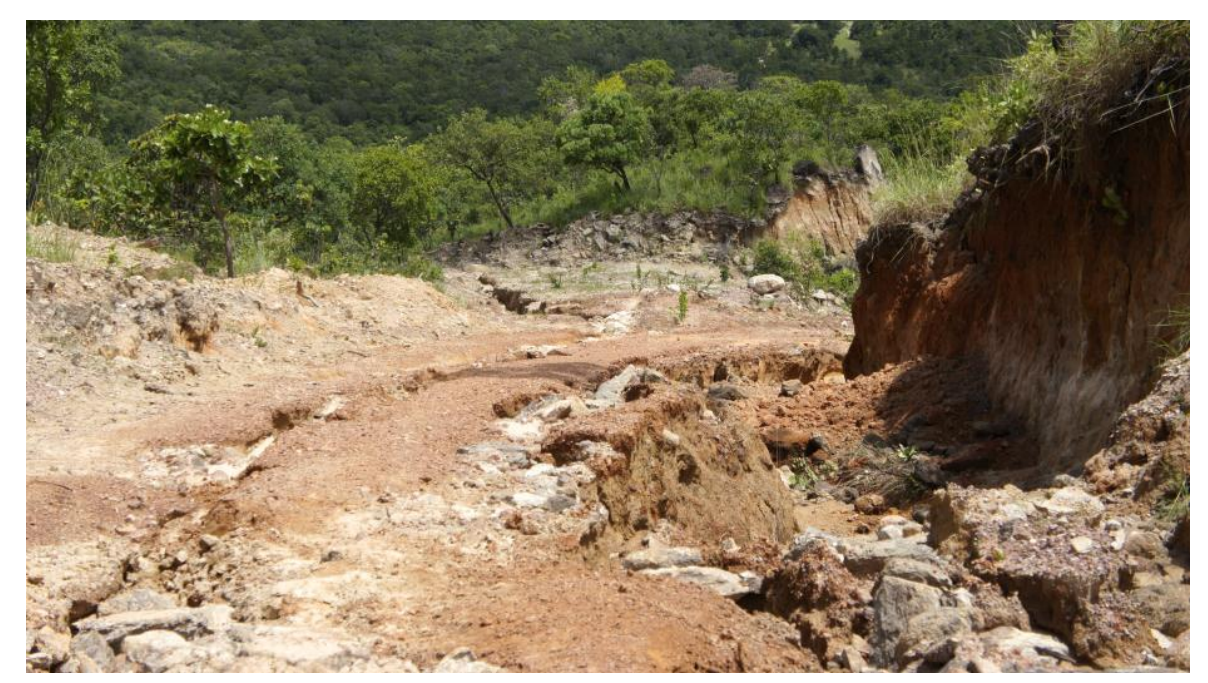

Figura 24: Estrada para o Vão do Moleque, fev. 2015. Fonte: a autora

\footnotetext{
${ }^{26}$ Conforme consulta realizada no Portal da Transparência, foi firmado convênio entre o Ministério da Integração Nacional e o município de Cavalcante para a construção da ponte sobre o Rio Corrente, no valor de $R \$ 260.000,00$. A vigência desse convênio teve início em 12/12/2014 e expira em 4/6/2016. Fonte: www.portaldatransparencia.gov.br , acesso em 25/4/2015.
} 


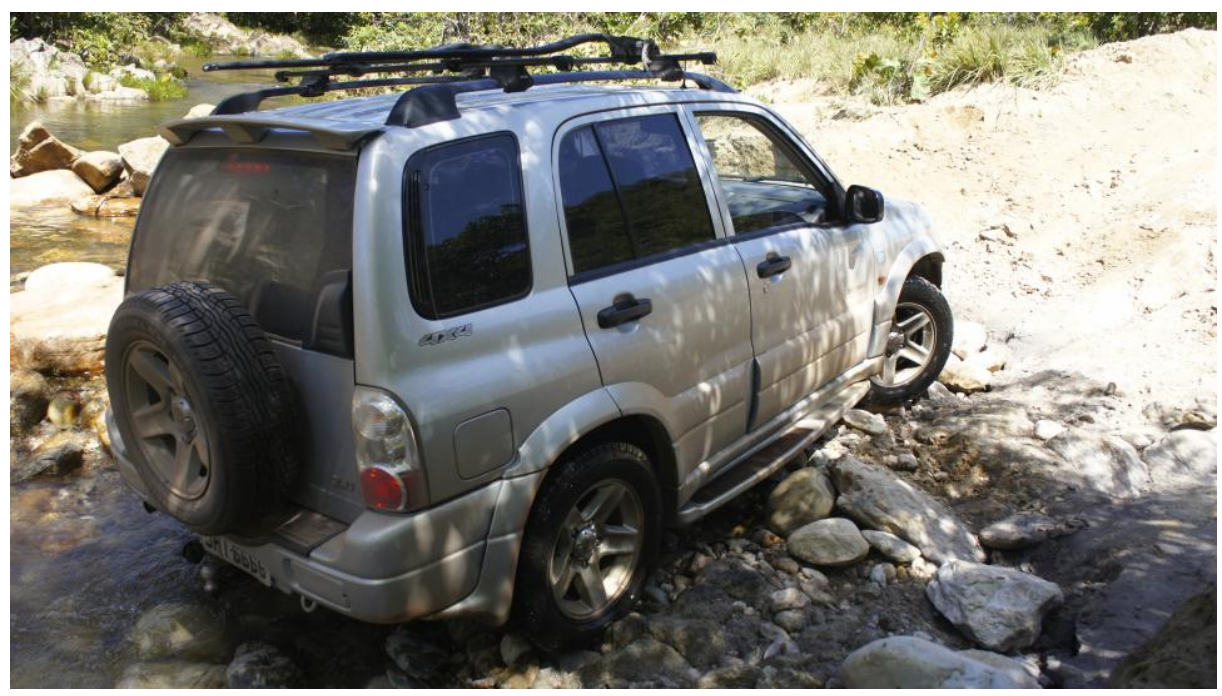

Figura 25: Travessia de córregos com pedras da estrada para o Vão do Moleque, fev. 2015. Fonte: a autora.

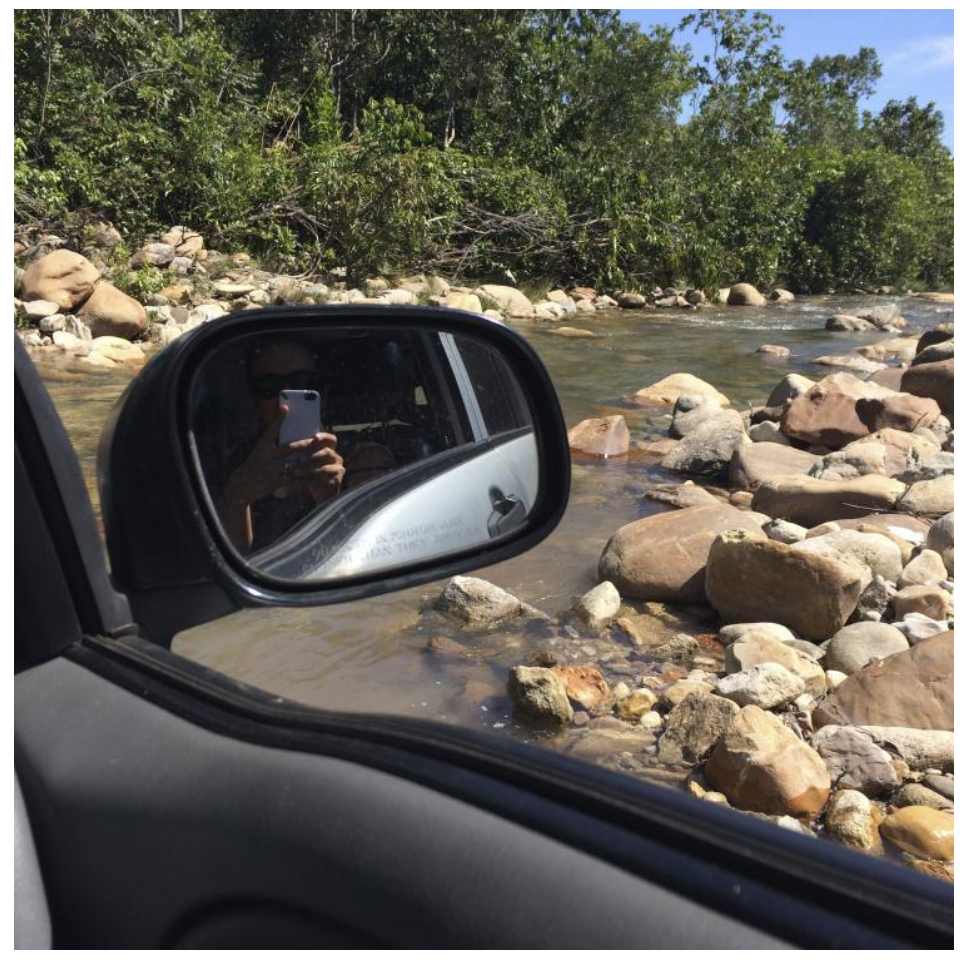

Figura 26: Dificuldades na estrada para o Vão do Moleque, fev. 2015. Fonte: a autora.

Chegamos exatamente às $12 \mathrm{~h} 30$ na casa de Dona Aimiram, que nos recebeu com um sorriso enorme, convidando-nos imediatamente para entrar, reclamando que, se tivesse sido avisada, tinha preparado um almoço para nós. (Naquele momento eu soube que tinha ido com a pessoa certa, pois Beto, meu guia, era muito querido por eles). 
Ao entrarmos na casa, construída de concreto, com cobertura de telha, pelo Programa de Habitação, Beto foi direto para o fogão à lenha dizendo que nós estávamos com fome e que tínhamos ido para almoçar, apesar de não termos avisado. Ela achou que sua comida estava simples demais e ficou meio constrangida, mas Beto, muito extrovertido, disse que não era para ela se preocupar com nada e começou a lavar as louças que estavam em sua pia. Fiquei feliz ao ver que Dona Aimiram possuía água encanada na pia de sua cozinha, que era uma grande varanda com uma mesa grande, onde sentamos, de onde avistávamos uma grande serra, da qual ela "puxou" a água, havia uma plantação de mandioca e milho, e vários pés de pimenta.

Já no início de nossa conversa Dona Aimiram, ao saber do tema da pesquisa, disse logo do grande entrave para a qualidade de vida dos Kalunga do Vão do Moleque: "Eu costumo falar que nossa saúde, nossa educação, nosso desenvolvimento em geral está relacionado à estrada", disse Dona Aimiram.

Muita indignada, ela contou que pessoas já morreram por causa da falta de estrada. Em 2014, uma criança de dois anos morreu porque estava doente. Choveu muito, o Rio Paranã encheu, não tendo como levar a criança para cidade, ela veio a falecer. Ela disse que se chovesse enquanto estivéssemos lá, teríamos que esperar a estrada secar por alguns dias. Segundo ela, ninguém passa na estrada por pelo menos dois dias quando chove.

O único transporte que há no Vão do Moleque é um caminhão "pau-de-arara", de propriedade particular, duas vezes por semana. Ele vai para Cavalcante na terça e volta ao Vão na quarta, vai na sexta e volta no sábado, ou seja, os moradores do Vão do Moleque precisam dormir na cidade quando vão sacar o Bolsa Família ou a aposentadoria, ou quando vão ao médico, ou resolver qualquer outro assunto que somente é possível ser resolvido em Cavalcante.

Dona Aimiram e seu marido, Seu Manoel, sabem da potencialidade de seu território para o turismo. Fosse a estrada melhor, eles acreditam que seria possível gerar renda do turismo e da agricultura. Eles informaram que aderiram ao PAA e plantaram muito abóbora, mas não tiveram como entregar os produtos, por falta de transporte, já que ninguém tem carro por falta de estrada. Seu Manoel falou indignado que até conseguiria comprar um carro popular, pois ele e Dona Aimiram são pedreiros e ganham por empreitada. Mas para ter um 
carro no Vão, eles precisam de muito dinheiro, pois teriam que comprar um carro potente e com tração $4 x 4$ para atravessar os córregos e subir a serra.

Eles disseram saber o quanto o cerrado é rico e que poderiam também tirar renda do extrativismo do cerrado, mas se sentem impotentes perante à falta de mobilidade.

Um dos sonhos de Dona Aimiram é que seus filhos e netos pudessem ficar no Vão do Moleque. Ela acredita que se tivesse uma estrada melhor eles permaneceriam em seu território, pois eles teriam mobilidade para gerar renda e até mesmo estudar. Ela diz que “jovem não fica em lugar que não tem desenvolvimento porque os jovens gosta das moda, gosta de ter um carro".

Depois seguimos para a casa de Seu Mochila, pegamos alguns caminhos que não são estradas, são mais trilhas abertas no meio do mato. Porém, são muitas trilhas abertas e acabamos no perdendo. Beto achou que teríamos que atravessar um córrego barrento, que isso não seria necessário se não tivéssemos nos perdido. Mas aí o carro ficou. Atolou. Felizmente, uma caminhonete que estava próxima puxou o carro do atoleiro com uma corda. Mesmo estando em uma caminhonete $4 \times 4$, eles disseram que também haviam atolado ali naquele mesmo lugar no dia anterior. Entendi o que Dona Aimiram dizia. Não há pontes em córrego nenhum. Nem mesmo pontes de madeira como costuma-se ver nos meios rurais. Por sorte, Seu Mochila morava antes do córrego, retornamos e conseguimos encontrar sua casa.

Seu Mochila ao nos ver chegar já sabia que tínhamos estado atolados e começou logo falar sobre sua tristeza de não ver seu lugar desenvolvido por falta de mobilidade.

Seu Mochila também acredita que o turismo poderia ser uma fonte de recurso para eles, inclusive fez um curso de guia de turismo, ofertado na semana anterior. Foram 68 alunos, 5 do Vão do Moleque, 6 do Vão de Almas e o restante do Engenho II. Entristeceu Seu Mochila o fato de os Kalunga do Vão terem tido tão pouca participação no curso. Mas a motivação para fazer o curso ainda é baixa para aqueles que estão isolados ali no Vão do Moleque, já que a estrada não deixa que os turistas cheguem até ali. No entanto, Seu Mochila não se conforma, pois sabe de todo o potencial de exploração turística existente ali, falando com muita propriedade o que o turista gosta. Ela sabe que o cerrado preservado, os vãos de 
serra, as rochas, os rios e sua cultura são atrativos para aqueles que moram na cidade e querem contato com a natureza.

Rita, moradora do Engenho mas "nascida e criada no Vão do Moleque", havia falado do isolamento do Vão do Moleque devido a ausência de pontes: "é o córrego que nos prende. [...] às vezes vem as verbas mas num chega esse trabalho pra nós".

Outro limitador da liberdade de ir e vir no Vão do Moleque relatado por Rita é a falta de transporte público. "Se a gente quer ir e quer vim, a gente tem que pagar R\$25 para ir e R\$ 25 para voltar do Vão do Moleque até Cavalcante" em um caminhão de propriedade particular. "E nós agradece por que nós não temos outros. Não tem outra solução. Como a estrada é ruim, não tem manutenção a gente até que agradece mesmo é o caminhão porque um ônibus tem mais facilidade de tombar do que o caminhão".

A falta de liberdade para ir e vir devido à falta de pontes, estrada e transporte é a principal razão dos Kalunga saírem do Vão do Moleque: "Foi por isso que eu abandonei o meu lugar, por causa do transporte. O dinheiro de duas diárias de serviço que era para eu ajudar na minha roça eu tinha que gastar em transporte", relatou Rita.

Sabendo do efeito da divulgação, ela diz que o sonho dela era acompanhar alguém para filmar e fazer uma reportagem acompanhando a travessia dos Kalunga para o Vão do Moleque no caminhão pau-de-arara. "Para as pessoas verem o sofrimento que é". São $140 \mathrm{~km}$ de Cavalcante até lá e é preciso atravessar cinco rios sem ponte, pois, segundo Rita, somente o Rio Prata possui ponte.

Já o caminho para o Vão de Almas foi imensamente mais fácil do que o do Vão do Moleque. São 20 km de asfalto de Cavalcante até Teresina de Goiás. Então, anda-se mais 40 km em estrada de chão. Passa-se pela comunidade Kalunga da Ema e depois desce-se a longa Serra do Pouso do Padre, de onde se vê todo o Vão de Almas e o Vão do Moleque (figura 27). Apesar de íngreme, a estrada estava bem transitável, com algumas pontes de passagem e somente alguns córregos para se atravessar por dentro da água, mas nenhum com o nível de dificuldade encontrado no Vão do Moleque. A informação é que na época da seca, é bem mais fácil chegar, pois vários dos córregos que atravessamos são intermitentes. 


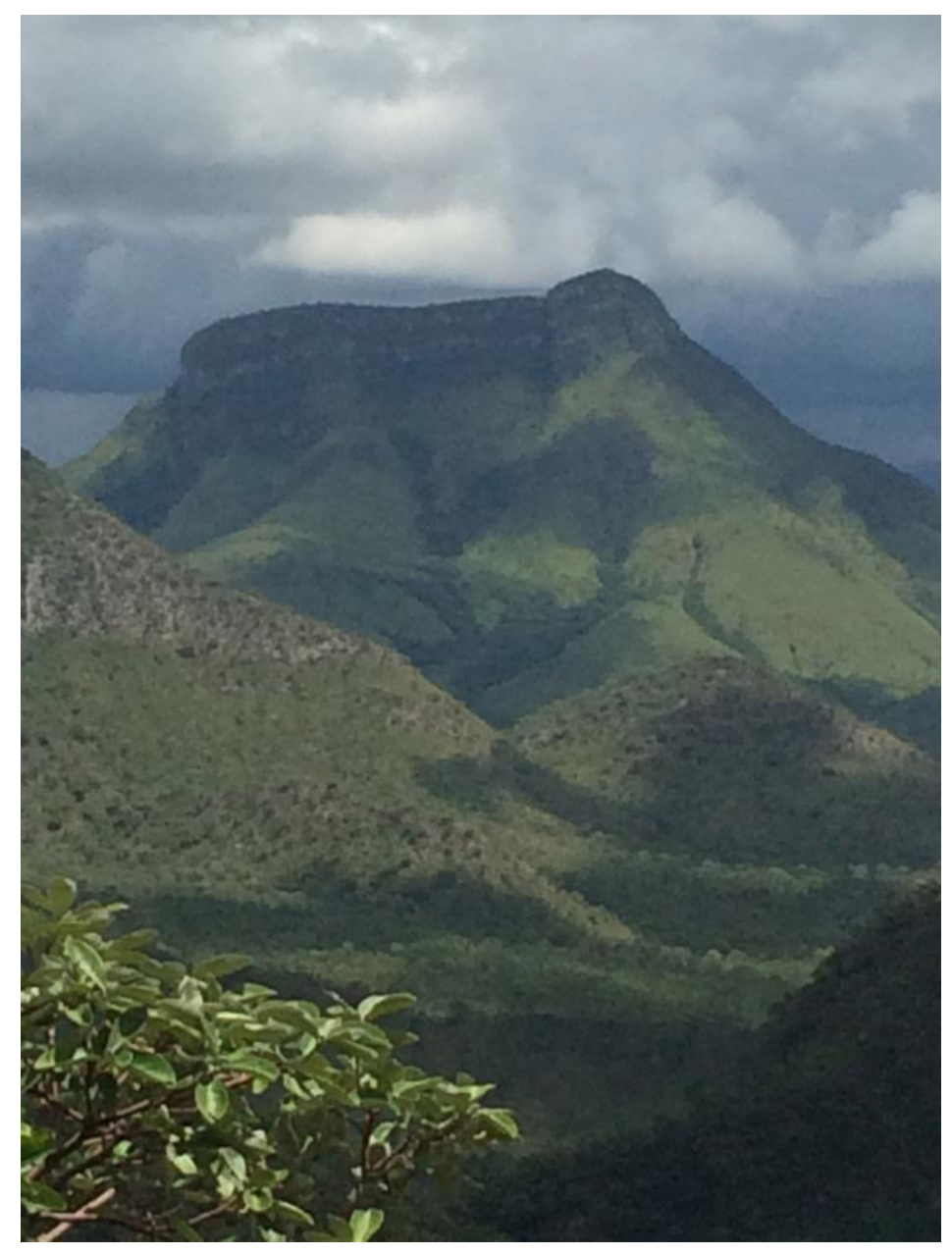

Figura 27: Caminho para o Vão de Almas, mar. 2015. Fonte: a autora.

Foram duas horas de Cavalcante ao Vão de Almas. Ao passarmos pela comunidade Kalunga da Ema, no município de Teresina, e ainda no alto da serra, vimos as casas dos programas de habitação do Governo - todas de concreto com telhas de cerâmica, caixas d'água e ligação de energia elétrica, em um povoado mais concentrado. Ao chegarmos ao Vão de Almas, não mais vemos as casas de concreto. As casas, bem mais distantes umas das outras, são, a maioria, de adobe e telhados de palha

A estrada até chegar no Vão de Almas, apesar de ainda ser de chão, é comemorada pelos moradores. Seu Albertino, 75 anos, "nascido e criado" no Vão de Almas, relatou que quando um antigo prefeito de Cavalcante começou a abrir a estrada para o Vão de Almas, o IBAMA tentou embargar a obra, ao que Seu Albertino não pode aceitar: "[...] veio aí o cabra chefe do IBAMA e veio aqui para encerrar a estrada. Eu falei a ele: O senhor tem é um coração muito ruim, doutor. Porque nós aqui tá mais é cansado com o coração arrebentado, 
cansado de carregar gente doente viva na rede para a cidade, mulher nova na hora de ter criança. E ele também não falou mais nada. A estrada tá aí."

Dona Titinha, esposa de Seu Zezinho, 40 anos, mãe de 6 filhos, diz que a vida melhorou muito desde que estrada foi construída. Há apenas 5 anos, eles precisavam colocar as pessoas em uma rede e ir carregando em um burro ou andando até a cidade, conforme tinha relatado seu Albertino. Ela lembra que muitos chegaram a morrer no caminho. Hoje, os moradores do Vão de Almas contam com o transporte particular no caminhão pau de arara, que pelo menos vai diariamente, apesar de só retornar no dia seguinte. Assim, os moradores do Vão de Almas também precisam dormir na cidade quando vão sacar seus benefícios da seguridade social ou acessar serviços de saúde.

Mas a estrada do Vão de Almas não alcança a maior parte das casas, pois não foi feita uma ponte sobre o Rio das Almas. Como a maior parte dos moradores moram após o Rio, na época de chuva, só se atravessa de canoa. Eles contam que na época da seca é possível atravessar o rio em um carro com tração $4 \times 4$ ou de caminhão, já que ele fica bem raso.

Pude presenciar como é atravessar para o lado de lá do rio, pois eu pretendia conversar com Dona Dainha, uma das mais antigas moradoras do Vão e conhecida por ser a rainha Kalunga. De onde eu estava acampada, no quintal de Seu Zezinho, andamos de carro por cerca de 15 minutos (demorou mais por que tivemos que parar para bater a enxada na estrada para o carro passar, já que tinha chovido muito à noite e uma vala havia se formado na estrada) até a beira do Rio das Almas, onde deixamos o carro para atravessar por meio de uma canoa (figura 28). De lá, andamos cerca de 1 hora até o próximo rio, o Capivara, onde atravessamos a pé. Andamos, bem rápido, mais uns 30 minutos, quando avistamos uma escola e começou a chover. Paramos para esconder da chuva, e Seu Zezinho resolveu perguntar se Dona Dainha estava em casa, já que teríamos que andar mais uns 40 minutos, segundo ele. Daí fomos informados que ela estava em Goiânia. Depois de andar mais de 1h30, e rápido, fiquei meio frustrada por não ter a chance de conhecer a tão falada Dona Dainha. 


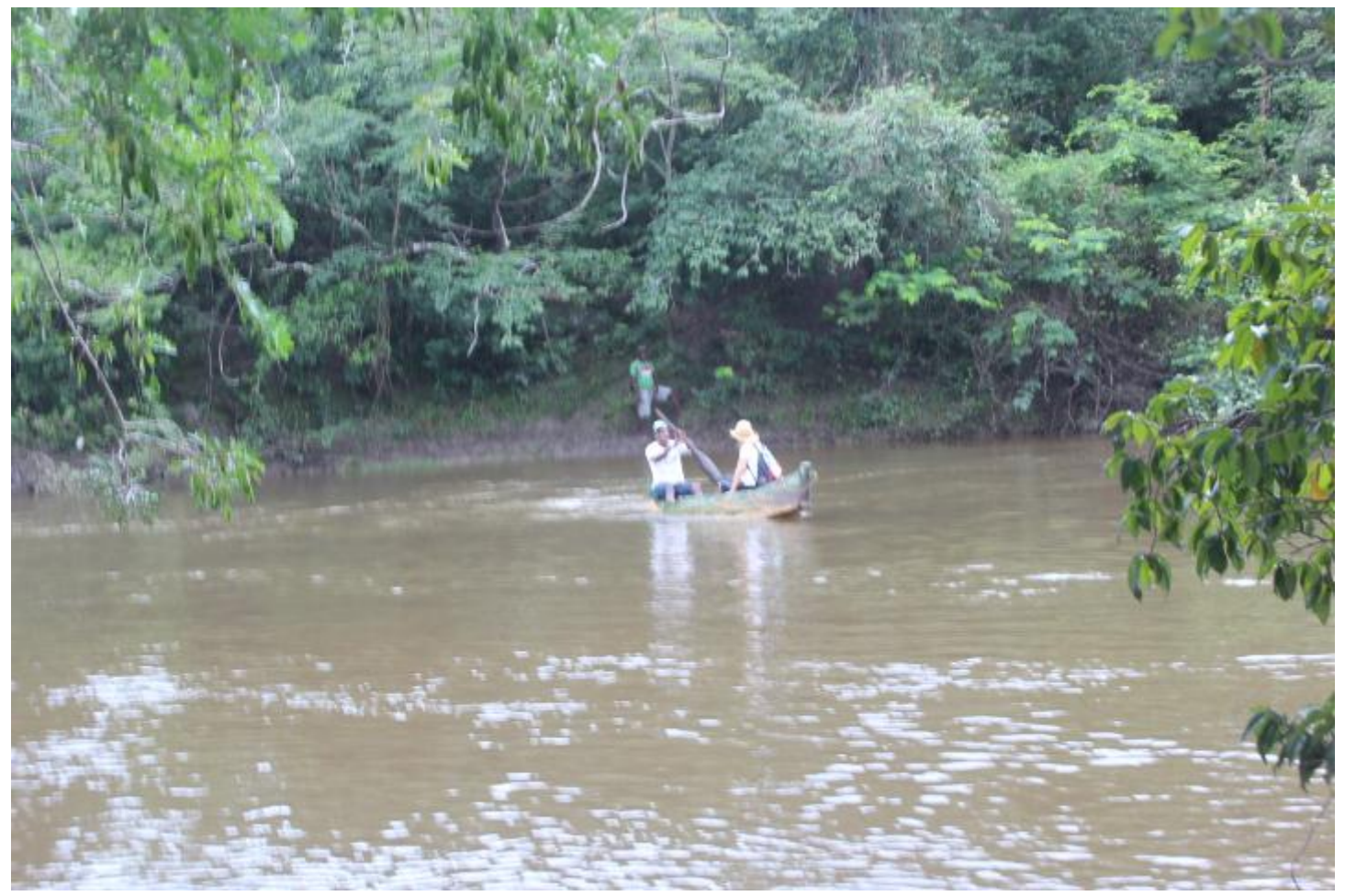

Figura 28: Travessia de Canoa no Vão de Almas para chegar à escola, fev. 2015. Fonte: Beto Baiano.

Mas, aproveitando que estávamos em uma escola, conversei com a merendeira e uma professora da escola, já que no caminho encontramos crianças e adolescentes andando longas distâncias para ir para escola.

Dona Percília dos Santos Rosa, 52 anos, merendeira, começa a conversa com certa revolta porque, em suas palavras, "nada chegou, tudo falta: a estrada, luz para todos, transporte, ponte". A professora Irene interrompe e diz: "Basta falar que a vida aqui é sofrida. Já diz tudo". E Dona Percília concorda: "Muito sofrimento aqui. Quando tá aqui dentro é bom, mas pra sair e até chegar!”

Dona Persília fala sobre a dificuldade enfrentada pelas crianças por causa de uma medida da prefeitura que fechou metade das escolas dentro do Vão de Almas a fim de juntar as crianças em poucas escolas e colocar transporte escolar. Por causa disso, muita gente perdeu emprego, e as crianças precisam andar muito para chegar na escola, já que o transporte escolar, devido à falta de pontes nos rios e córregos, não transita na época de chuva. Segundo ela, o carro do transporte escolar, que é um ônibus com tração $4 \times 4$, está na prefeitura parado, e as crianças andam em baixo de chuva, atravessam os rios de canoa e levam até 2 horas caminhando para ir estudar. 
Dona Persília fala com muita tristeza do isolamento em que eles se encontram: "Nós agradece muito o Jonas (o dono do caminhão pau-de-arara que faz o transporte privado até a cidade), por que ele é que faz a linha aí, nós paga (caro) mas nós agradece. Por que é o único transporte que tem".

As mulheres grávidas vão para a cidade quando a data prevista do parto está próxima. Elas ficam nas casas de amigos ou parentes Kalunga que têm casa em Cavalcante, pois não conseguiriam chegar a tempo do parto caso sentissem as dores dentro do Vão de Almas, falou com tristeza Dona Persília.

A pesquisa do MDS mostrou que o acesso a serviços públicos de saúde e educação são dificultados pela falta de infraestrutura dentro do território Kalunga. Somente $25 \%$ declaram haver transporte escolar em sua comunidade, tendo as crianças que se deslocarem para as escolas a pé, de barco ou bicicleta.

Escola de ensino médio e posto de saúde somente foram identificados na comunidade do Engenho II, com acesso restrito a somente 140 famílias, pois não há estradas de ligação entre o Vão de Almas e o Vão do Moleque e o Engenho II. Para frequentar o ensino médio ou ir ao médico, os moradores de grande parte dos povoados Kalunga devem se deslocar até a cidade sede de seu município por meio do transporte privado, pois não há oferta de transporte público coletivo pelo município no território Kalunga. 


\subsection{SE QUISER LUMIAR É COM ÓlEO MESMO, POR QUE NÃO TEM ENERGIA. O ÓlEO É DANADO PARA ATACAR AS VISTAS DA GENTE. MAS AQUI É ASSIM.}

Conforme mencionado no Capítulo 1, das 772 casas visitadas no Território Kalunga nos três municípios pela equipe contratada para realizar a Pesquisa do MDS, somente 35,6\% eram de alvenaria e 53,3\% eram adobe/barro/argila. Apenas 44,4\% possuíam energia, seja da rede, de gerador ou solar. Outros 43,9\% ainda vivem com a luz gerada pela lamparina de querosene, e 10,3\% não possuem nenhuma forma de iluminação. Ainda, 58,5\% não possuíam vaso com descarga. O escoamento das casas, quando havia, era para fossas, em $43 \%$ dos casos, ou, em 55,9\% das casas, o escoamento era feito a céu aberto.

Cheguei na casa de Dona Eva, moradora do Vão de Almas, no fim da tarde, chovendo, e lá estava uma linda e magra senhora de 75 anos, mas com uma catarata forte nos olhos que a impossibilitava de me enxergar completamente. Mesmo assim, ela tecia na companhia de três netos (figura 29), que moram com ela, já que os pais foram para a cidade. Ela diz que aproveitou para tecer o algodão a fim de fazer coberta enquanto descansava, já que chovia e ela não podia ir para a roça.

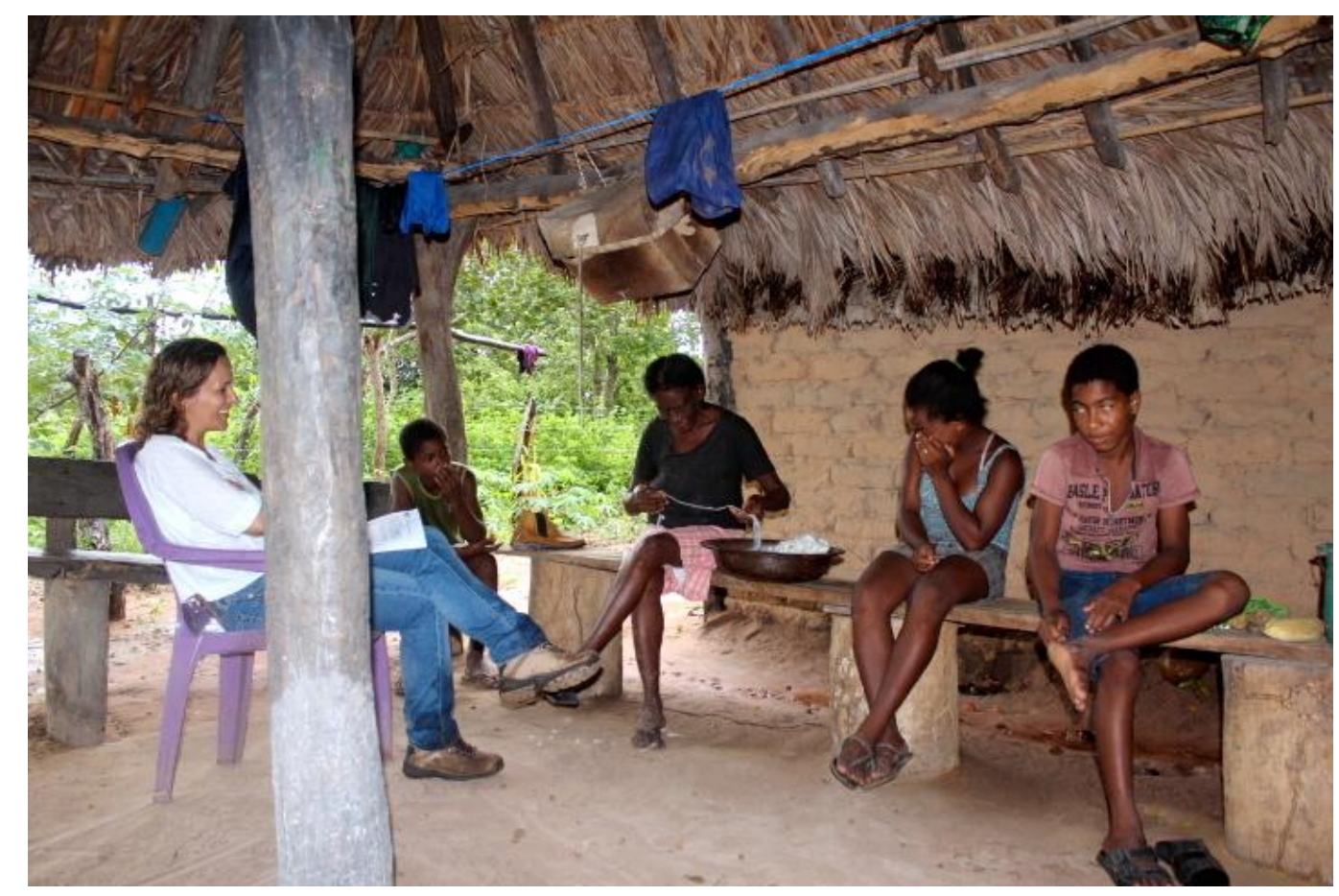

Figura 29: Dona Eva, do Vão de Almas, tecendo algodão, mar. 2015. Fonte: Beto Baiano. 
Dona Eva considera que, "comparado ao que era antes, melhorou muito". Mas falta muita coisa ainda. Em sua opinião, o mais importante seria ter energia elétrica e um posto de saúde dentro da comunidade: "Se quiser lumiar é com óleo mesmo, por que não tem energia. O óleo é danado para atacar as vistas da gente. Mas aqui é assim.”

O “assim" é escuro. Numa casa de adobe, com cobertura de palha, com poucas janelas, Dona Eva vive sem energia, sem água encanada ou até mesmo uma cisterna na porta de sua casa, e cozinha em seu fogão a lenha, em uma cozinha aberta, pois a fumaça, segundo ela, "atrapalha seus olhos". No fim do dia, quando ela já preparava o jantar de seus netos, a cozinha era completamente escura, e ela, por que já tem destreza para lidar com seus poucos utensílios sem iluminação, conversava comigo e preparava milho assado para eu comer.

Na casa de Seu Zezinho, onde acampamos para dormir, o breu era total. No horário que jantamos, 19h, não era possível enxergar nada fora do raio de iluminação da lamparina. Seu Zezinho também pensa na energia elétrica como a principal política pública para melhorar a condição de vida dos moradores do Vão de Almas. Ele vê como uma possibilidade de geração de oportunidades para ele e sua família. Se tivesse energia, ele diz que poderia comprar uma bomba para puxar água do rio para que sua família tivesse água na porta de casa e também para irrigar um horta. Ele fala da dificuldade de se fazer hortas ou outro cultivo mais perene devido aos longos períodos de seca. Ele relatou ter comprado quatro motores a diesel para puxar água do rio, mas todos pifam. Ele também já comprou gerador para ter luz, mas, após uns 6 meses, pifou. Ele diz que desistiu: "Uma hora a energia elétrica chega né".

Dona Titinha (figura 30) e Seu Zezinho gostariam de sair do Vão de Almas por causa das dificuldades sofridas pela ausência do Estado. Mas se tivesse energia elétrica, agua na porta de casa ("não precisa nem ser dentro", diz eles) e banheiro com vaso e chuveiro, Dona Titinha e Seu Zezinho dizem que não sairiam nunca de sua terra.

“Aqui significa o começo da minha vida. A gente criou amor no lugar, mas a gente tinha vontade de viver num lugar melhor. De ter uma casa boa. [...] aqui quem tem estudo sai, só tá ficando quem não tem estudo, porque não tem para onde ir [...] Mas se pôr energia aqui eu não quero sair. A gente tem vontade de ir para a cidade por causa da energia. Se pôr energia eu não quero sair”. 
Titinha gostaria de ter eletrodomésticos que facilitassem seu trabalho doméstico do dia a dia e o bem estar de sua família: "Com a energia, a gente pode comprar uma geladeira, guardar as coisas na geladeira para não perder [...] A gente puxa uma agua do rio, faz uma horta aí e tem verdura o tempo todo, não precisa comprar na cidade”.

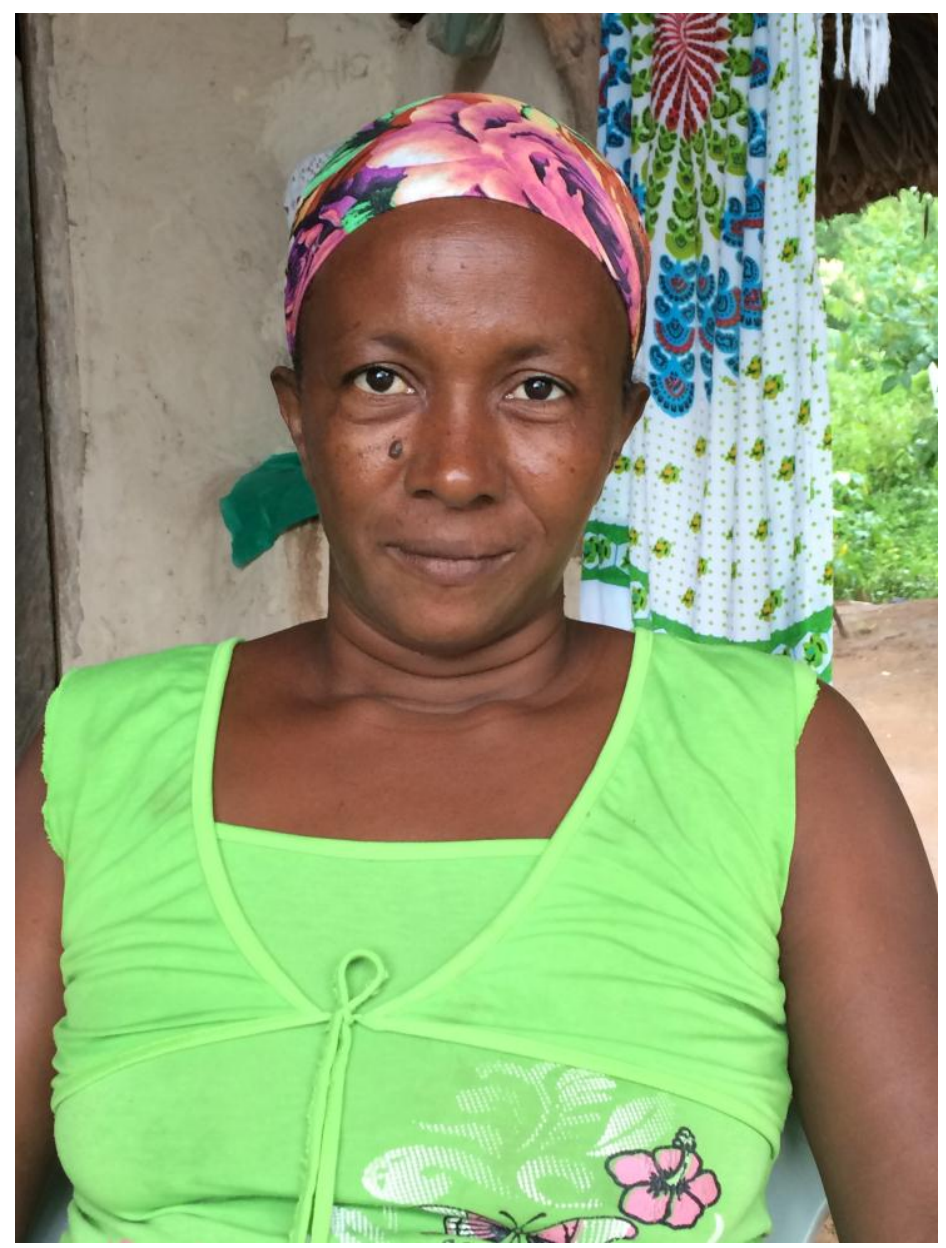

Figura 30: Titinha, Vão de Almas, mar. 2015. Fonte: a autora.

Titinha fala com muita paixão sobre seus desejos: "Meu maior sonho é ter energia e uma casa boa com água, banheiro, água quente e uma horta”, suspira.

No Vão do Moleque também não há energia elétrica. Porém, Rita, além de outros Kalunga, relatou que foram colocados $30 \mathrm{~km}$ de poste, com fios, no caminho para o Vão do Moleque, em 2004. Mas os postes não têm ligação de rede para lugar algum. Rita fala indignada: "Quem tá usando a rede? Cipó!" 
Rita tem consciência de que algo muito errado ocorreu. Ela pergunta "Para onde foi a verba? Não mandaram a verba só pela metade."

A informação dada pelos Kalunga entrevistados é que, do município de Cavalcante, somente o Engenho II recebeu a energia elétrica, conforme relatado por Seu Cirilo. Porém, as comunidades de Teresina de Goiás (Ema, Diadema) e de Monte Alegre (Riachão, Contenta) possuem energia elétrica.

A casa de Seu Zezinho e Dona Titinha situa-se à beira do Rio Paranã, e do lado de lá do rio está a comunidade da Contenta, onde é possível avistar pontos de luz da iluminação das ruas e casas. É com muita tristeza que os moradores do Vão de Almas, vivendo no escuro, veem a luz tão perto mas longe de seu alcance. Seu Albertino apresentou a indignação geral: “Aí no barranco do rio do lado de lá num tem energia? Na Contenda? Num tem lá na Ema? Qual é essa faculidade que tem de lá ter (luz) e aqui num tem? Por que que nós aqui num adquiriu um prefeito pra ter dó de nós aqui dentro pro lado de cá?”

Se 1.967 famílias estão registradas no Cadastro Único como quilombolas nos três municípios que abarcam o território Kalunga, sendo 1.092 somente no município de Cavalcante, e sendo que cerca de 140 famílias residem no Engenho II, conforme relato de Seu Cirilo, estima-se que cerca de 800 famílias, considerando a média de quatro pessoas por família em uma equivalência aproximada de 3.200 pessoas, vivem sem eletricidade ou energia solar no Vão de Almas e no Vão do Moleque. 


\section{4. É BOM DEMAIS PODER TOMAR BANHO NO CHUVEIRO QUENTE, PODER IR NO BANHEIRO DENTRO DE CASA. NOSSA, É MUITO DIFERENTE!}

A Pesquisa do MDS, conforme demonstrado no Capítulo 1, mostrou que a grande maioria dos Kalunga em 2011 utilizava as águas dos rios e nascentes, seja por encanamento da água das nascentes nas serras, valendo-se da gravidade, ou buscando a água com baldes e tambores nos rios e córregos. A pesquisa identificou somente $38,2 \%$ das casas com água encanada em pelo menos um dos cômodos. A água das nascentes ou dos rios é utilizada para a limpeza, para o banho e também para beber, sendo que, neste caso, 98\% declaram filtrar a água

A casa de Seu Zezinho e Dona Titinha (figura 31) no Vão de Almas possui chão de areia solta, paredes de adobe, telhado de palha, poucos cômodos, e quase nenhum móvel. São três construções. Na primeira, há uma sala e dois quartos: em um quarto dorme o casal e no outro dormem os quatro filhos que residem com eles. Anexa está a cozinha, com o fogão a lenha, uma mesa pequena simples de madeira, um banco, dois filtros, e baldes de água. Ainda, há um rancho com uma geladeira não ligada, já que não há energia elétrica, uma grande mesa de madeira com cadeiras de plástico, onde eles fornecem a alimentação para eventuais turistas.

Além da energia elétrica, a casa de Dona Titinha e Seu Zezinho não possui água encanada. Ele buscam água para sua família no rio cerca de seis vezes ao dia, o que provoca fortes dores nas costas e pescoço diariamente, segundo eles. Ela lava roupa e louças no rio. Não há banheiro dentro ou fora da casa. Todos da casa tomam banho no rio e precisam usar o mato para suas necessidades fisiológicas, faça chuva ou faça sol. 


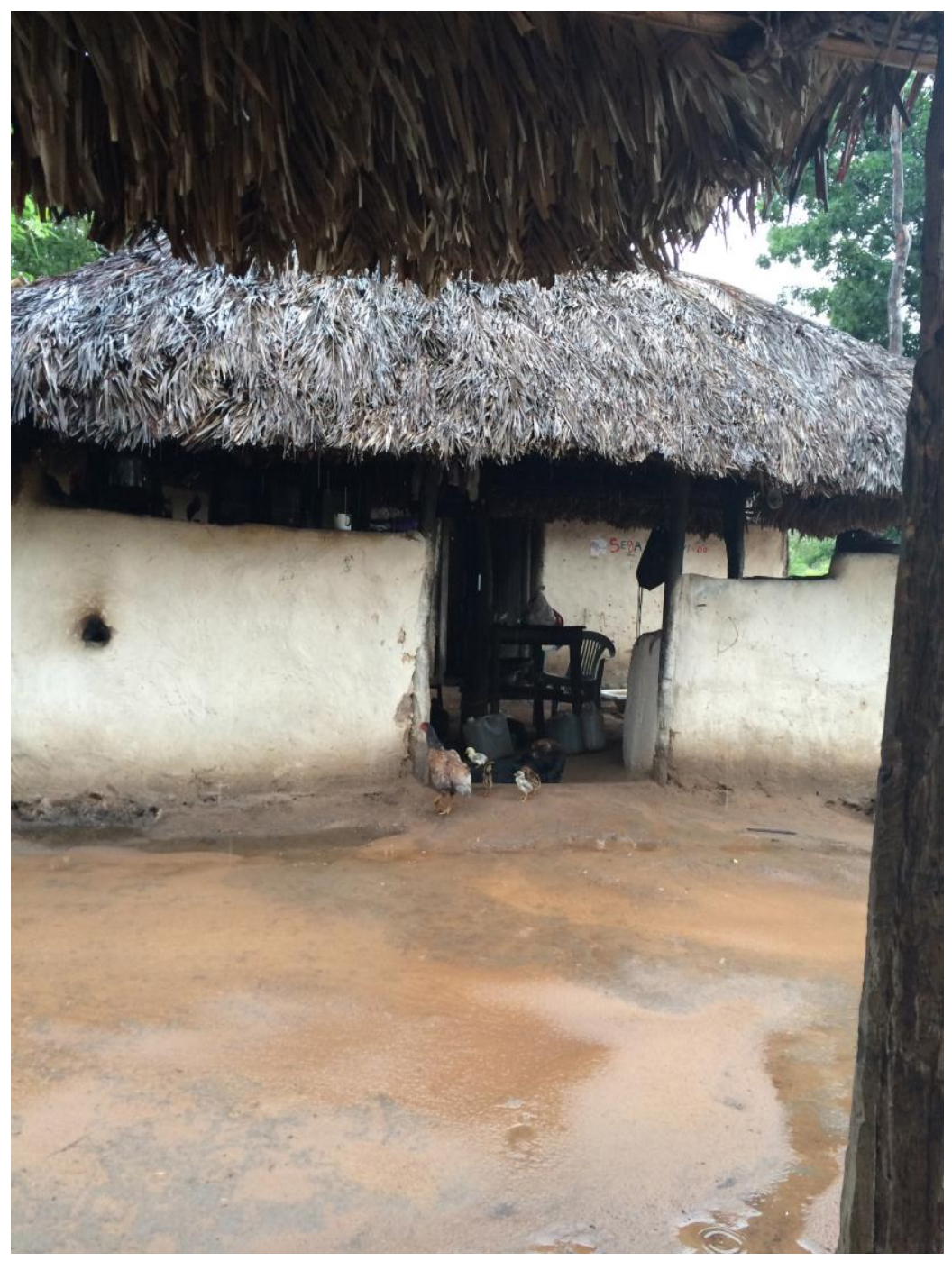

Figura 31: Casa de Seu Zezinho e Dona Tininha, Vão de Almas, mar. 2015. Fonte: a autora.

O chão de areia solta, o adobe, o telhado de palha, o fogão a lenha, a lamparina acessa e a ausência de banheiro e de água caracterizavam também a casa de Dona Eva (figura 32) e da maior parte das famílias do Vão de Almas.

Dona Eva, já com mais de 70 anos, é também quem busca água no rio e carrega no balde, ou "no pote", como ela chama, para lavar, cozinhar e beber. Dona Eva, com toda sua disposição, inclusive, busca água no rio para aguar um pequeno canteiro de folhas que ela cultiva ao lado de sua cozinha. Pergunto se o rio era perto e ela responde: "Se não tivesse chovendo, nós ia lá no rio procê ver a distância, é longe”, fala ela com certa revolta. 


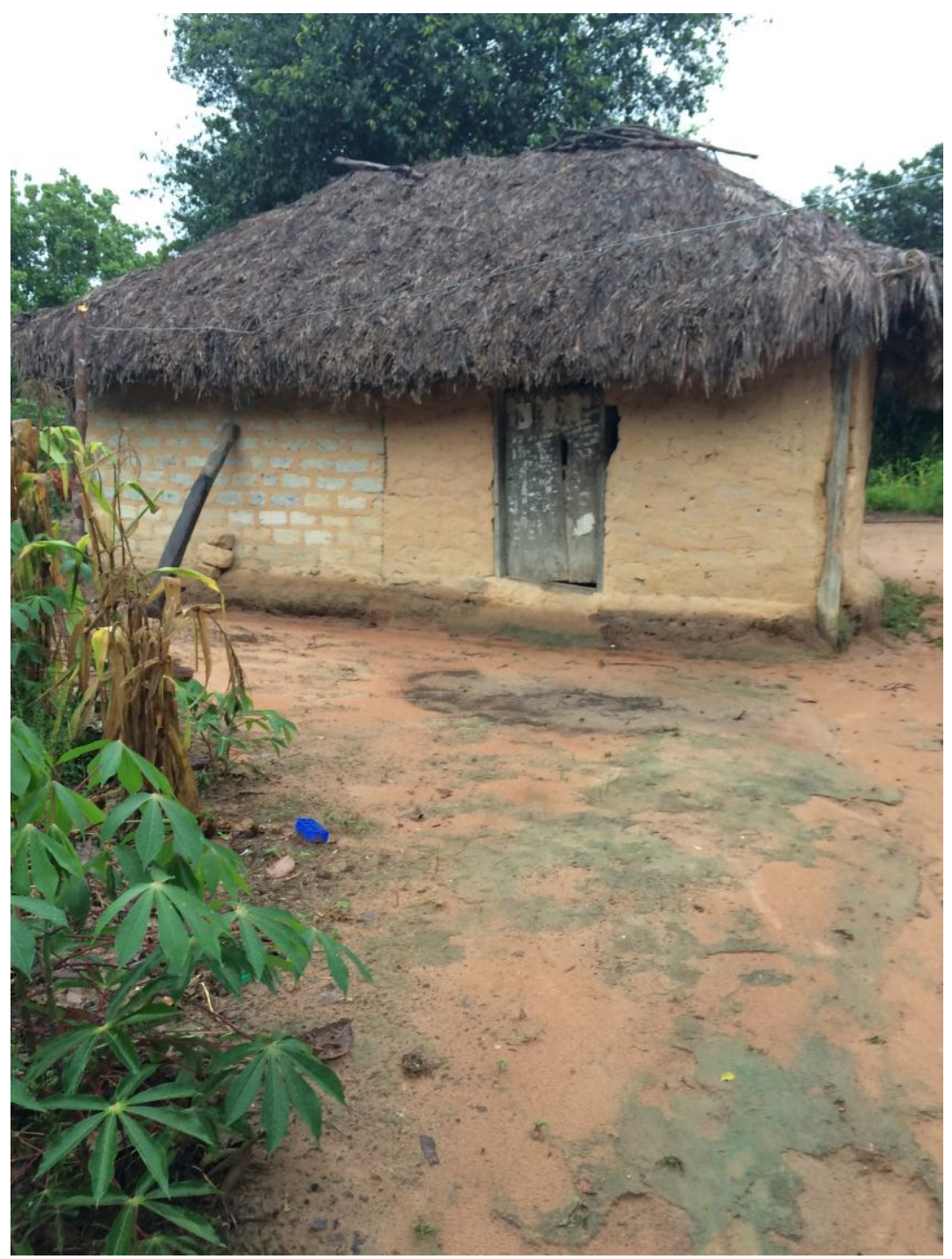

Figura 32: Casa de Dona Eva, de adobe e telhado de palha, típica do Vão de Almas, mar. 2015. Fonte: a autora.

Já Seu Albertino, de 70 anos, mora em uma das poucas casas de alvenaria e cobertura de telhado que vi no Vão de Almas. Perguntei a ele sobre a construção de sua casa: "Fui eu de meu bolso que eu paguei. Num tem nada de prefeitura. Num tem nada de projeto. Tem uma lei aí de dar moradia. Nada aqui nós nunca recebeu."

Seu Albertino, que é aposentado, construiu sua casa(figura 33), mas ainda não a pintou e não colocou banheiro nem pia, já que não tem água na porta de casa. Ele pretende pintar sua 
casa até o dia 15 de julho, quando vai fazer uma $\operatorname{sussa}^{27}$ para seus amigos do Vão, em comemoração a seu aniversário.

Já a água da casa de Seu Albertino é ele, em sua avançada idade, quem busca no rio. Segundo ele, ele busca o tambor de 20 litros e traz nas costas. Pergunto se ele sofre dores por isso, ele afirmou que, por ser "Kalungueiro", está acostumado, mas Seu Albertino (figura 34) apresenta um corpo cansado e bastante curvado, sendo bem provável que a necessidade de carregar água em tambores e baldes, até para beber, cause bastante dores naquele homem tão forte.

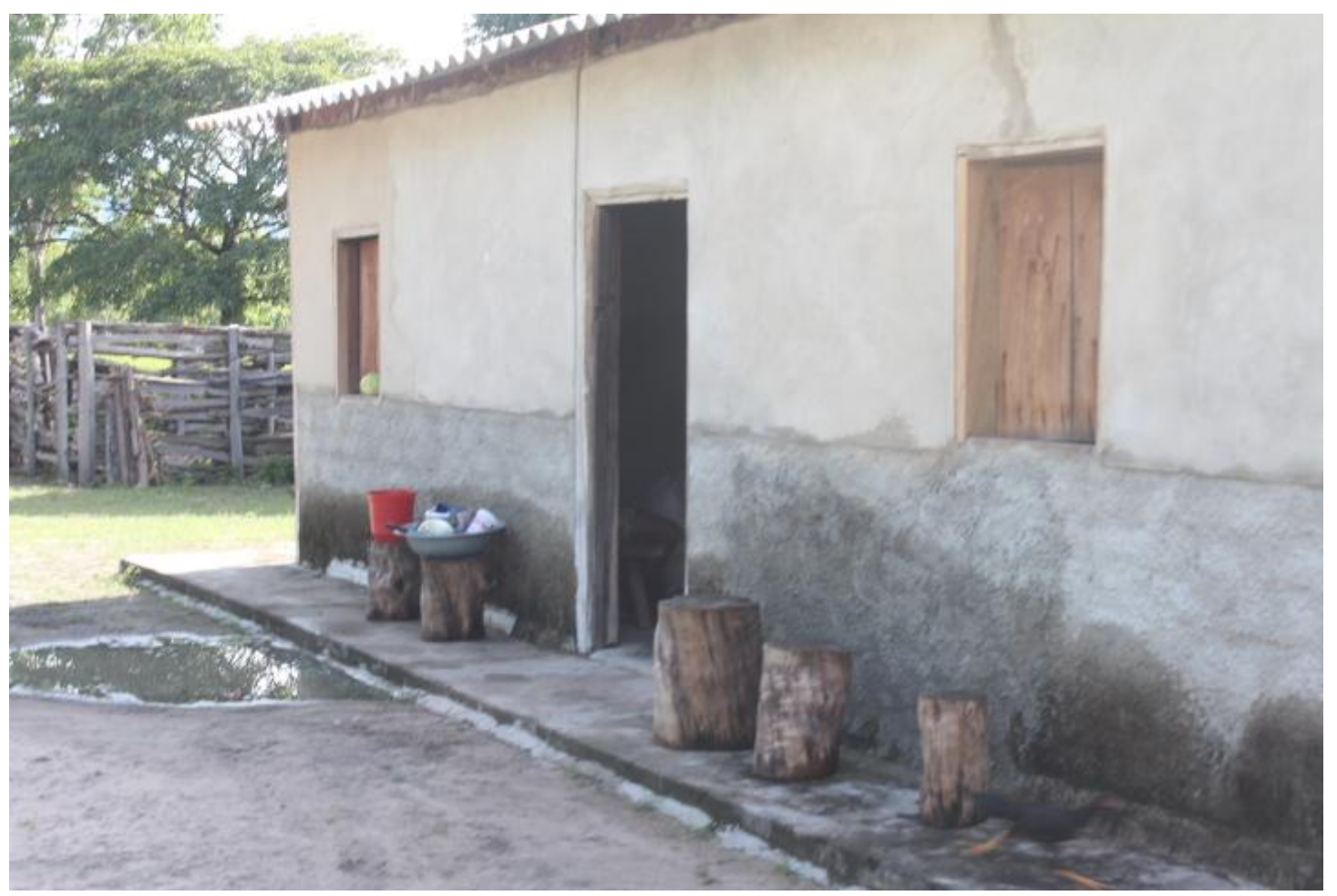

Figura 33: Casa de Alvenaria construída por Seu Albertino com sua aposentadoria, mar. 2015. Fonte: a autora.

${ }^{27}$ Dança e música Kalunga 


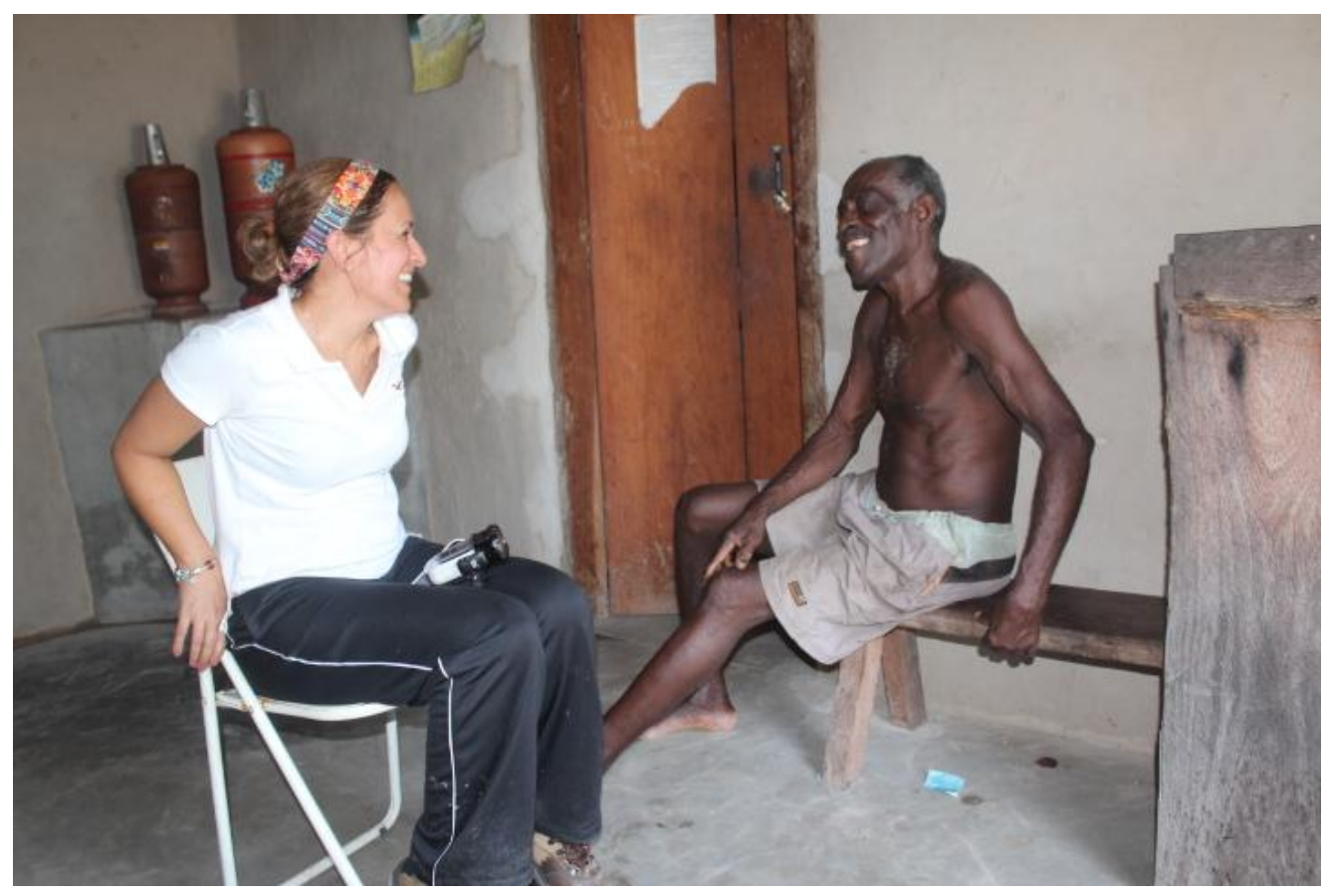

Figura 34: Seu Albertino da Comunidade do Vão de Almas, mar. 2015. Fonte: a autora.

O sonho de ter água quente e banheiro em casa relatado por Dona Titinha é o que Dona Getúlia, moradora do Engenho II, considera o maior indicador da qualidade de vida que eles ganharam depois da construção das casas pela FUBRA/UNB, contratada pelo Governo Federal. A construção de casas com banheiros, a água encanada e a energia elétrica trouxeram a qualidade de vida que Dona Getúlia não teve durante toda sua juventude: "é bom demais poder tomar banho no chuveiro quente, poder ir no banheiro dentro de casa. Nossa, é muito diferente!", relatou ela com a emoção de quem está lembrando das dificuldades por que já passou.

Rita, também do Engenho II, mora em uma casa pequena branca de janelas azuis de alvenaria e telhado de telhas de cerâmica de barro, com uma caixa d'água e energia ligada à casa, que foi recebida pelo programa habitacional federal (figura 35). Ela relatou possuir armário para guardar suas roupas, aparelho de televisão e de DVD, além de fogão e geladeira.

A melhora da qualidade de vida, relatado por Dona Getúlia e Rita, em virtude da implantação do Programa Habitacional, do Luz para Todos e da água encanada é compartilhada pelo moradores do Engenho, mas estes sentem a tristeza de ver seus parentes e amigos Kalunga do Vão de Almas e do Vão do Moleque isolados pela falta de estradas e pontes, no escuro e buscando água em baldes e tambores no rio. 


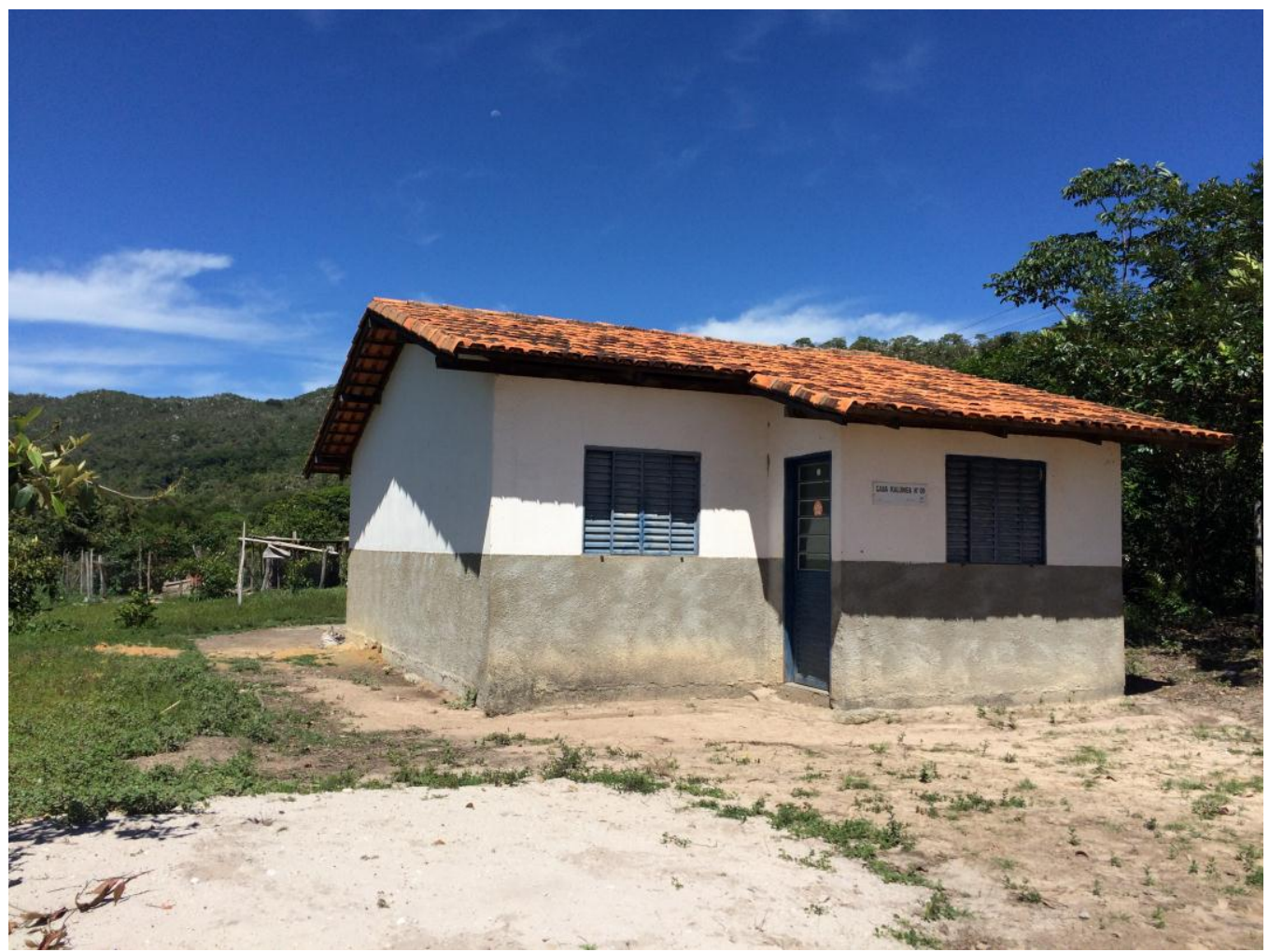

Figura 35: Casa de Rita, do Engenho II, construída pelo programa de moradias do Governo Federal, mar. 2015. Fonte: a autora.

Rita falou com muita revolta da falta de acesso à água dentro de casa no Vão do Moleque, onde os moradores, em sua maioria, precisam ir buscar a água no rio. Alguns precisam andar dois a três quilômetros para buscar água, e voltam a mesma distância carregando o balde na cabeça. Segundo ela: "Na época da seca, eles precisam ir buscar água no lombo do burro com o tambor de 20 litros". Na época da seca, os córregos intermitentes secam e só ficam os maiores rios, e mesmo assim, segundo eles, com pouca água, por isso eles precisam andar maiores distâncias.

Rita diz que nunca teve um animal de carga e sempre carregou esses tambores nas costas quando morava lá. Hoje ela tem a água encanada no Engenho e lava a roupa em tanquinho elétrico em casa, diferentemente das mulheres do Vão do Moleque e do Vão de Almas que têm que lavar as roupas da família no rio.

Rita falou muito da diferença entre os lugares dentro do território Kalunga e sabe que sua qualidade de vida só melhorou depois que se mudou do Vão do Moleque para o Engenho, quando se casou. Mas solidariza-se com as mulheres do Vão: “As mulheres do Vão precisam 
carregar água na cabeça, carregar roupa para lavar no rio, passar horas lá lavando e esfregando e depois carregam a roupa molhada pesada para casa. E ainda carregam lenha para cozinhar. As mulheres de lá ainda estão isoladas”, ela diz.

Dona Aimiram é uma das poucas mulheres do Vão do Moleque que não tem o sofrimento relatado por Rita, pois ela, além de ter recebido a casa do programa habitacional (figura 36), tem uma renda melhor por ter sido capacitada no serviço de pedreira e realizar serviços por empreitadas em obras em Brasília e Formosa. Com maior acesso ao dinheiro e por morar perto de uma nascente no pé da serra, Dona Aimiram comprou mangueiras e encanou a água para sua casa, valendo-se da gravidade.

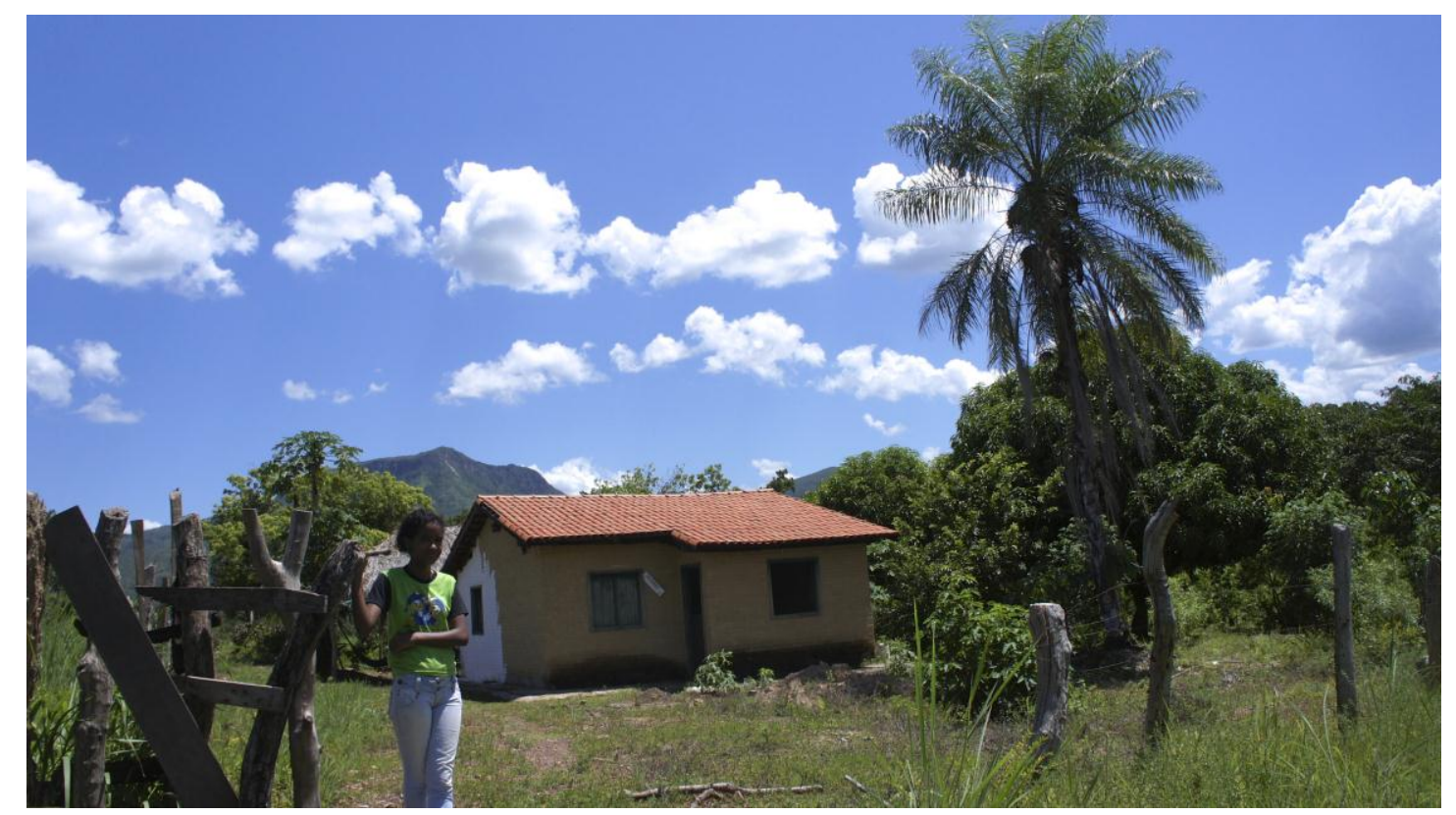

Figura 36: Casa de Dona Aimiram no Vão do Moleque, construída pelo programa de moradias do Governo Federal, fev. 2015. Fonte: a autora.

Dona Aimiram relatou que somente 60 casas de alvenaria foram construídas no Vão do Moleque, uma vez que foram priorizadas as famílias que moravam à beira das estradas. Segundo relatou Seu Mochila, cerca de 120 famílias ainda precisam ser beneficiadas pelo Programa Habitacional no Vão do Moleque. Ele diz que tem o nome de todas as famílias que ainda moram em casa de adobe e palha e que pretende fazer um ofício para levar para as autoridades federais a fim de ser dada continuidade na construção das casas no Vão. 
No dia em que chegamos ao Vão do Moleque, os moradores estavam especialmente felizes, porque estavam sendo instaladas, exatamente naquele dia, 50 cisternas de captação de água de chuva para consumo, reservatórios com capacidade para 16.000 litros, do Programa Água para Todos, do Ministério da Integração Nacional - MI (figura 37).

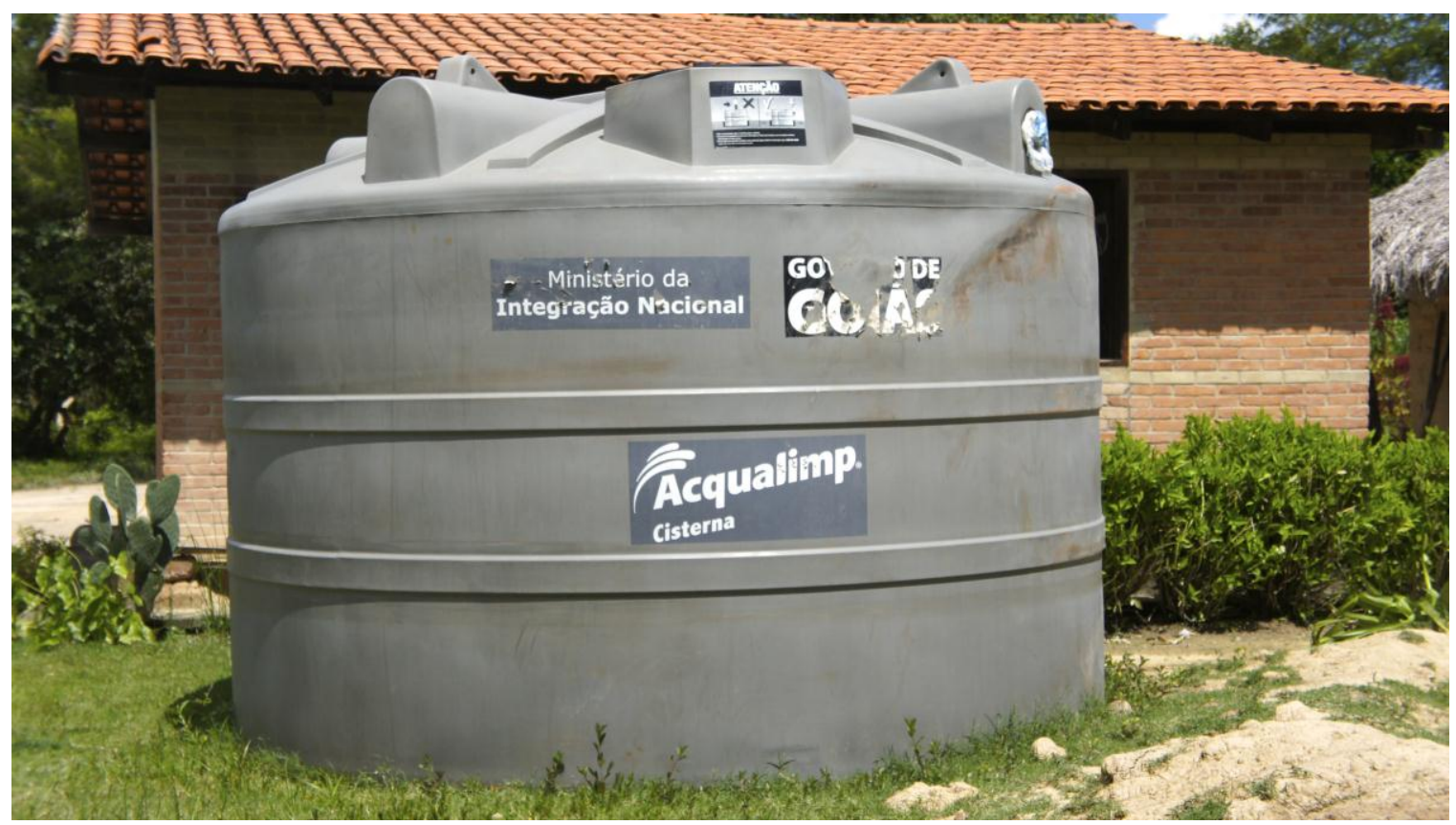

Figura 37: Cisterna de captação de água pluvial no Vão do Moleque, fev. 2015. Fonte: a autora.

As famílias que já não foram beneficiadas pelo Programa Habitacional, por não ter estrada de acesso a suas casas, segundo justificou Dona Aimiram, e ainda possuem casas com telhado de palha, ou seja as mais vulneráveis, ficarão de fora do programa do MI, pois não é possível captar a água nesse tipo de telhado. Outras 10 casas de alvenaria não receberão a cisterna por já possuírem algum arranjo próprio de captação de água, como é o caso de Dona Aimiram.

As cisternas já instaladas no Vão do Moleque, apesar de ainda serem em número insuficiente, poderão mudar a vida, em especial das mulheres que carregam baldes de água na cabeça, mas elas ainda terão que andar até o rio para lavar suas roupas, louças e tomar banho, já que a água deve ser priorizada para o consumo.

Seu Mochila, que mora em uma casa também de concreto e telha do programa de habitação, estava feliz pois sua cisterna tinha acabado de ser entregue, apesar de ainda não ter sido instalada. Com muitas galinhas no quintal e fogão à lenha do lado de fora da casa, a casa 
de Seu Mochila tinha a grande vantagem de estar a menos de 100m do córrego. Seu Mochila comprou uma placa solar para gerar energia e colocou uma bomba que joga água para casa. Assim, ele tem água na torneira da pia, onde Dona Iva, sua esposa, lavava a louça. Mas a água não é permanente. Quando os córregos secam, a água diminui no território. Com isso, muitos animais morrem e são jogados nos córregos, e eles bebem água poluída. Ele fala longamente da necessidade de se ter água potável para beber. "A água que a gente bebe na época da seca é somente por causa da necessidade de sede, mas é água de doença", ele diz.

Como Seu Mochila e Dona Iva são aposentados, a renda deles permite que eles consigam fazer alguns investimentos para melhorar sua qualidade de vida. Além da placa solar, Seu Mochila e Dona Iva também compraram uma antena para celular por R\$1.300,00. Mas não é sempre que dá sinal. Ciente de que o Estado deve prover telefonia, ele afirma que enquanto não for instalada uma torre no alto da serra, o problema de comunicação ali permanecerá. Não há muito que eles possam fazer com seu próprio dinheiro.

Seu Mochila também investiu em uma cisterna calçadão para captar água de chuva para a produção e para seus animais. Gastou $\mathrm{R} \$ 1.200,00$ em cimento e a construiu da maneira que achou que deveria. Porém, por falta de conhecimento da tecnologia de construção da cisterna, Seu Mochila viu sua cisterna desabar e seu rico dinheiro ir embora na primeira chuva que deu.

Solidário com os amigos e parentes Kalunga que não serão beneficiados pelas cisternas, Seu Mochila relatou estar mobilizando as pessoas que não têm telhado de telha para comprar 4 telhas de 16x16, que custam R\$320,00, segundo estimativa dele, para fazer um varal com calha para receber a cisterna do governo. "A água é para todos, o Governo Federal tá dando é para melhorar a situação dos Kalunga”, disse ele. Seu Mochila não se conforma da cisterna não chegar em todas as casas: "Se melhorar a situação de nós, nós não precisa de cidade".

Os moradores do Vão do Moleque e do Vão de Almas, em sua grande parte, precisam ter um lugar na cidade, para poderem ficar quando precisam ir ao médico ou fazer compras, e principalmente para seus filhos morarem quando estão no ensino médio. Primeiramente por que o transporte no caminhão pau-de-arara além de caro ( $\mathrm{R} \$ 50$ ida e volta) não vai e volta todos os dias. Segundo, por que, com a precariedade das estradas, a viagem é longa e 
cansativa, em especial para os mais idosos e mulheres com crianças. Finalmente, as escolas do Vão do Moleque e do Vão de Almas somente ofertam o ensino até o nono ano, assunto este que será abordado mais adiante.

Há uma vila em Cavalcante onde a maioria dos Kalunga construíram suas casas. As casas são, em sua grande parte, habitadas por idosos - muitos idosos vão para a cidade para ficar com os jovens que precisam estudar e ficar perto do posto de saúde.

A professora Irene, do Vão de Almas, relatou que mora em uma casa de adobe e palha, mas que pretende construir uma casa na cidade de Cavalcante. Perguntei para ela por que ela não construía sua casa no Vão de Almas já que a sua era de adobe. Ela disse que custa mais, por causa do transporte de material de construção para o Vão de Almas, e que "a maioria das pessoas fazem isso. Tem uma casa na cidade para poder resolver as coisas." 


\subsection{OlHA A AgUA do PARANÃ Agora PROCÊ VER A AgUA QUE AS CRIANÇAS BEBE, SÓ TEM BARRO [...] A BARRIGA DELES TEM MAIS É VERME}

O Programa Cisterna que acabara de chegar no Vão do Moleque não alcançou os moradores do Vão de Almas. É verdade que o território Kalunga tem muitos rios e córregos, que estão cheios na época das chuvas. Porém, na época da seca muitos secam, e, conforme relatado por Seu Mochila, a água desses rios e córregos acabam sendo veículo de doenças.

Seu Zezinho, do Vão de Almas, sabe que as cisternas significam para os Kalunga não só ter o conforto de ter a água na porta de suas casas mas também ter água de qualidade; entretanto, se mostra descrente com os programas governamentais: "As promessa é demais. Não adianta ter prefeitura na cidade se não ajudar o município, o povo. Prefeitura para meu entendimento era para ajudar as comunidades: com escola boa, com água para as crianças não beber água poluída. Olha a água do (Rio) Paranã agora procê ver a água que as crianças bebe, só tem barro. [...] a barriga deles tem mais é verme.”

A informação dada por seu Zezinho foi confirmada pela médica do Programa Mais Médicos, Dra. Marta Damasco, que trabalha em um posto de saúde em Cavalcante. Dra. Marta relatou seu conhecimento empírico sobre a saúde dos Kalunga no município de Cavalcante. Como não há prontuário eletrônico, as informações estão sistematizadas no DATASUS somente por internação e mortalidade.

Em 18 meses de prática médica em posto de saúde no município de Cavalcante, Dra. Marta observou que entre os meses de setembro a novembro, após o final da seca, as queixas mais frequentes são diarreia, constipação, dor no estômago e outras relacionadas a doenças de veiculação hídrica. Verificou também alguns resultados de exames de fezes com indicação de giardíase. Os sintomas estão presentes em crianças e adultos.

Nas minhas visitas ao Vão de Almas, observei que muitas crianças e mulheres apresentam um aumento do volume da barriga e perguntei à Dra se poderia ser por causa de vermes. Dra Marta explicou que podem ser verminoses, além de carências nutricionais, como de vitamina B e de ferro. Após o período da seca, são diagnosticadas pessoas com anemia carencial, devido à alimentação pobre em nutrientes. 
Na seca, eles não conseguem plantar a abóbora, o jiló, o maxixe, e outros legumes que são de costume alimentar dos Kalunga. Na seca, a paisagem do Vão do Moleque e o Vão de Almas é de areia e árvores secas. Assim, a alimentação deles é somente do que eles conseguem comprar com o Bolsa Família ou a aposentadoria: arroz, feijão, café, sal, açúcar e macarrão praticamente.

Outra queixa de saúde frequente feita pelos Kalunga, relatada por Dra. Marta, também é causada pela falta de água: a cervicalgia, presente principalmente nas mulheres, que chegam a andar $5 \mathrm{~km}$ a $6 \mathrm{~km}$ para pegar água e ainda a carregam na cabeça.

Segundo ela, algumas já mostraram o resultado da ressonância magnética, feita pelo SUS em Goiânia ou em clínicas privadas, e o diagnóstico foi comprovado: desgaste das vértebras cervicais, deslizamento de vértebras, hérnia de disco, e outros. Elas são solicitadas pelos médicos a pararem de carregar água, porém eles sabem que isso é difícil, pois muitas não têm quem o faça para elas.

Dra. Marta preocupa-se com o fato de os Kalunga beberem a água dos rios e riachos sem tratamento. Segundo ela, mesmo no Engenho, onde a água vem encanada da serra, a qualidade é comprometida com a contaminação pela terra, pois as mangueiras, por não estarem bem enterradas, quebram/furam ao serem pisoteadas por pessoas, gado, cavalos e carros. Assim, fezes de animais fazem solução de continuidade com a água. Como a água não é tratada para beber ou cozinhar, os Kalunga em geral sofrem com verminoses e diarreias.

A pesquisa do MDS verificou que em 2011 74,3\% das casas no Território Kalunga utilizavam água para beber proveniente de rios e $15 \%$ das nascentes e poços. Vários Kalunga, $63,3 \%$, relataram tratar a água em casa antes de beber, sendo que, destes, 98,9\% tratavam por meio do filtro de barro.

Realmente, em todas as casas que visitei, foi verificada a existência de filtros de barro, em muitas até mais de um. Porém, andando pelo território com alguns Kalunga, observei alguns deles abaixarem para tomar água de córregos coletando com a mão, por acreditarem na qualidade da água. No Engenho, onde a água é encanada da nascente e chega por gravidade às casas, Seu Cirilo acredita que a água é saudável: "Filtrada por Deus, pela natureza", disse ele. 
Porém, como não há rede pública de esgoto no território, a percepção da médica quanto aos riscos das mangueiras sobre a terra pode estar certa, uma vez que a Pesquisa do MDS indicou que, em $55.9 \%$ das casas, o esgoto (onde se tem banheiro, chuveiro e pia) ia para valas a céu aberto e em $20,7 \%$ para buracos ou fossas rudimentares.

De acordo ainda com a Pesquisa do MDS, em 2011, somente havia banheiros em $58,5 \%$ das casas do território Kalunga. Quase metade da população Kalunga vive sem banheiro na residência. 


\subsection{COMPARADO AO QUE ERA ANTES, MELHOROU MUITO}

A política de saúde foi talvez a mais elogiada pelos Kalunga, junto ao programa Bolsa Família, que será abordado mais adiante.

Em todas as conversas com mulheres ${ }^{28}$, eu perguntava quantos filhos tinham. Em todos os casos, com exceção de Titinha, 40 anos, cujos 6 filhos estão todos vivos, eu recebia a resposta de um número $\mathrm{X}$ de filhos nascidos, e um número $\mathrm{Y}$ de filhos vivos. Dona Persília, por exemplo, de 52 anos, teve 8 filhos e somente 5 estão vivos, e este foi o padrão de respostas: Dona Eva, de 75 anos, teve 12 filhos, apenas 8 vivos, Rita, 44 anos, teve 8 filhos e apenas 7 estão vivos, Dona Getúlia, 56 anos, teve 10, mas 9 estão vivos. Até mesmo Seu Albertino, 75 anos, me informou que teve 18 filhos, mas somente 10 estão vivos.

Para algumas perguntei se a mortalidade infantil ainda era comum no Território Kalunga, e a resposta mais comum foi que "a vida está mais fácil hoje". Os três filhos de Dona Percília morreram com poucos meses ou até mesmo dias depois de nascidos. Hoje ela acredita que isso não ocorre mais porque as mães fazem o pré-natal e as crianças tomam vacina regularmente. Dona Percília diz que nunca realizou um pré-natal e que ganhou seus filhos em casa com parteira.

Segundo os relatos, atualmente as grávidas realizam o pré-natal e os Agentes Comunitários de Saúde chamam a ambulância da cidade para buscar as grávidas quando a data do parto está próxima.

A pesquisa do MDS mostrou que 97,4\% das mulheres haviam feito o pré-natal durante a gravidez dos filhos que ainda eram crianças durante a pesquisa.

Ainda, a pesquisa verificou que em 2011, dos 399 que responderam sobre partos, $83 \%$ relataram ter tido o parto com médico ou enfermeira, e $15 \%$ haviam tido somente com parteira.

\footnotetext{
${ }^{28}$ Ressalto que fiz a opção de conversar com mulheres acima de 40 anos, uma vez que o propósito da pesquisa era verificar os efeitos das políticas sociais nos últimos 10 anos. Uma mulher mais jovem poderia não ter conhecimento para comparabilidade entre períodos antes e depois. A única mulher mais jovem com quem conversei foi a Professora Irene, 25 anos. Ela não possui filhos ainda.
} 
Dona Iva, mulher de Seu Mochila, foi parteira, mas hoje ela não mais realiza partos na comunidade, por que "hoje em dia a mulher tem que ter filho é nos hospital", disse seu Mochila. Mas, segundo ele, infelizmente, já ocorreu de mulheres morrerem no Vão do Moleque esperando um carro ir buscá-las para o hospital, por causa da precariedade da estrada.

No Vão de Almas, Dona Eva relatou ter sido parteira "a vida inteira". Segundo seus cálculos, ela já realizou o parto de 271 crianças. Mas hoje ela não faz mais parto por que "as mulheres tão tudo trapalhada". Ela disse achar arriscado realizar partos hoje pelo fato de as mulheres não repousarem e não tomar cuidados durante a gravidez.

Ela diz que ainda há muitas parteiras no território Kalunga. Relatou ter ido a um encontro recente em Brasília, que reuniu parteiras Kalunga. Apesar de não ter entendido o propósito do encontro, ela disse ter gostado: "Era umas palestras. Todo mundo brincando de roda. Batendo nas cadeiras uma das outras". Ela diz que assinou "um bocado de coisa lá, mas não sei o quê, por que eu não sei ler. Mas eu assinei. Saí assinando.” Ela diz que também ganhou um DVD, mas não sabe para que também pois lá não tem energia: “eu falei que não ia trazer por que não tinha onde pôr, mas mandaram eu trazer".

A pesquisa do MDS mostrou que $95 \%$ das crianças tinham a caderneta de saúde da criança, sendo que $86,3 \%$ das mães as tinham em mãos no momento da pesquisa. Verificou-se ainda que $97 \%$ das crianças possuíam Certidão de Registro de Nascimento, o que foi também constatado nas conversas realizadas, pois, segundo todas as mulheres, as crianças já saem do hospital com a Certidão.

Somente durante campanhas de vacinação as crianças do Vão de Almas e do Vão do Moleque tomam a vacina dentro da própria comunidade. $\mathrm{E}$ apesar do valor da passagem no "pau-de-arara" (crianças pagam o transporte no mesmo valor do adulto), suas mães as levam para o posto de saúde na cidade de Cavalcante, segundo relatos de todas as mulheres entrevistadas.

No Engenho II, há um posto dentro da própria comunidade. Seu Cirilo relatou com muito orgulho o fato de o Engenho II ter assistência médica regular no posto de saúde. Com o Programa Mais Médicos, essa comunidade passou a ter médicos em seu posto, que fora 
construído por uma ONG inglesa. O atendimento do Médico do Programa Mais Médicos já foi diário, mas passou a ser semanal. Porém, quando não há médicos, Seu Cirilo disse que eles têm assistência de enfermeiros e do Agente Comunitário de Saúde, que são Kalunga. No caso de emergência, estes ligam para o município que manda um carro buscar o paciente e levá-lo ao hospital, o que ocorre com tranquilidade, segundo ele, pelo fato de a distância até Cavalcante ser pequena e a estrada ser razoavelmente boa.

Dona Getúlia, também do Engenho II, por sua vez, não ficou satisfeita com o fato de ter diminuído a frequência de médicos na comunidade. Ela contemporiza: "Se comparar com antes que não tinha nada, melhorou muito. Tem posto de saúde aqui dentro. Já teve médico visitando as casas nos últimos anos". Porém, por motivos de reforma no posto, a presença de visitas de médicos havia cessado nos dois meses anteriores à nossa conversa. Mais tarde, conversando com a médica do Programa Mais Médicos, fui informada que o médico que estava responsável pela visita aos Kalunga aproveitou o período de reforma do posto de saúde para ir a Cuba realizar uma cirurgia e que aguardava recuperação para retornar.

A pesquisa do MDS, durante a entrevista com as lideranças, verificou a presença de Agente Comunitário de Saúde em 100\% das comunidades Kalunga. O trabalho do Agente Comunitário foi muito elogiado por uns e criticado por outros. Foi reconhecida a relevância de o Agente ser membro da comunidade pelo fato de ele ter proximidade e conhecer as pessoas. Porém, alguns relataram insatisfação por não receber a visita do Agente Comunitário de Saúde em suas casas. Rita, por exemplo, reclamou que "nunca nenhum agente bateu em minha porta de casa para perguntar como eu estava, para medir minha pressão".

Dona Percília também não mostrou satisfação quanto ao trabalho prestado pelo Agente Comunitário de Saúde do Vão de Almas, que é Kalunga: “Tem uns aí que faz né, mas o que vai lá em casa mesmo, num faz nada [...] eu mesmo num chamo ele pra nada. Ele corre atrás de um carro quando as pessoas precisam, mas ir nas casas mesmo, ele não faz.”

Dona Titinha e Seu Zezinho, no entanto, haviam relatado que o Agente Comunitário de Saúde visita sua casa para pesar e medir as crianças, devido à condicionalidade do Programa Bolsa Família. Dona Getúlia considerou importante a presença do Agente Comunitário de Saúde, pois ele, além de ser o articulador com o serviço de saúde na cidade, 
traz informações importantes sobre benefícios aos quais eles têm direito, como o salário maternidade.

Os Kalunga do Vão do Moleque e do Vão de Almas, quando precisam de assistência médica, devem ir ao posto em Cavalcante. A maior parte dos entrevistados não fazem exames ou consultas de rotina. Os moradores que possuem telefone celular rural, como Seu Mochila no Vão do Moleque e Seu Zezinho no Vão de Almas, são aqueles que ligam na cidade para chamar a ambulância, a pedido do Agente ou dos próprios moradores, quando alguém precisa ser socorrido.

Os Kalunga têm amplo conhecimento sobre as ervas e plantas medicinais, fazendo pouco uso de remédios. Quando os filhos ficam doente, Titinha e Seu Zezinho relataram que os tratam com remédio caseiro feito de ervas. "Eu sou remedeiro. Eu conheço todas as ervas boa do mato: Raiz de assa-peixe e folha de laranja são bons para febre. Mas não pode pôr açúcar, se não é chá, não é remédio."

Dona Eva também atribuiu sua saúde à raizada que ela faz. Ela relatou não fazer exames ou consultas preventivas. No entanto, ela considerou de grande importância que os Kalunga do Vão de Almas tivessem acesso a um posto de saúde dentro do território. Ela afirmou que "comparado ao que era antes, melhorou muito", pois quando sentiu-se mal, ela disse que foi uma única vez, a ambulância foi buscá-la, e ela foi atendida na cidade, onde fez o tratamento de pneumonia.

Seu Albertino, também já idoso, me mostrou uma ferida em sua perna, que, segundo ele, não curava. Ele relatou que foi ao hospital de Cavalcante para consultar, mas que pediram que ele fosse a Goiânia realizar exames. Mas quando chegou ao hospital público de Goiânia a que havia sido indicado, não havia agendamento de exames para ele. Seu Albertino, aposentado, pagou uma clínica particular para fazer o exame. Pagou também alguns remédios que a médica particular prescreveu. Somente o antibiótico, ele conseguiu no posto de Cavalcante: "Tive que ficar sem comprar o café para comprar esses remédios". Seu Albertino falou com revolta, porque ele sabe que teria direito a ter a consulta, aos exames e aos remédios pelo SUS, mas não teve acesso. 
Dona Percília reclamou que, devido à estrada ruim e ao transporte, os moradores do Vão de Almas somente conseguem chegar em Cavalcante no fim da manhã. Porém, as fichas médicas são distribuídas logo cedo. Então as pessoas precisam dormir em Cavalcante para pegar a ficha no outro dia cedo, ou "se tiver necessidade, tem que ir para Campos Belos e pagar médico particular", segundo ela. 


\subsection{A FOME QUE TINHA ANTIGAMENTE, ESSA DEUS NUM DEIXA ENTRAR MAIS}

"Nós já sofremos demais. Já tá o fim do sofrimento", disse Rita ao afirmar com muito alívio que a alimentação diária é garantida em sua casa. Ela diz que não deixa sua mãe nem seus filhos sem verdura e, de vez em quando, tem uma carne.

Ela diz que, no passado, quando moravam no Vão do Moleque, ela chegou a passar três dias deitada em uma cama por não ter o que comer. Às vezes quando estavam com muita fome, ela e sua família comiam coco do cerrado até que arrumassem comida. "Às vezes a gente já chegou a comer o fubá do coco, que é comida horrível para a gente comer. A gente come se não tiver outra solução para não morrer de fome."

Perguntei a ela se hoje no Vão do Moleque alguém ainda vive assim, e ela afirmou que não, pois quem não tem salário, tem o Bolsa Família, ou consegue alguma renda do que planta, minimamente, e os idosos recebem a aposentadoria rural: “Já ninguém tem as dificuldades que tinha antes de sobrevivência. Que era difícil era, muito difícil. Eu cheguei muitas vezes a chorar de fome. Por que a fome dói”.

Na maioria das casas visitadas, via-se plantação de milho, abóbora e de mandioca, deve-se considerar que o trabalho de campo ocorreu em época de chuva, nos meses de fevereiro e março. Nessa época a disposição de verduras e cereais cultivados é naturalmente maior. A renda advinda do trabalho ou de benefícios da seguridade social, como o Bolsa Família e a aposentadoria, é utilizada em grande parte para a compra de arroz, feijão, macarrão, óleo, sal, café e açúcar, em especial na época da seca. A produção, no entanto, não é suficiente para gerar renda.

Os vãos da serras são os lugares da roça. Tanto os Kalunga de Monte Alegre, como de Teresina e Cavalcante produzem nos vãos, mas as áreas são de produção individual - cada família sabe em qual canto pode produzir, é "hereditário", segundo Seu Cirilo. Os vãos estão próximos aos rios, o que deixa a terra mais úmida e própria para o plantio.

A agricultura e pecuária são basicamente de subsistência. Cada qual produz o seu, sem organização coletiva. Houve relatos por moradores do Engenho II e do Vão do Moleque de tentativas de vender seus produtos para a prefeitura por meio do Programa de Aquisição de 
Alimentos $^{29}$. Porém, em todos os casos, foram relatadas dificuldades de entrega dos produtos por falta de transporte e de recebimento do pagamento.

No entanto, grande parte dos Kalunga entrevistados desconhece o Programa de Aquisição de Alimentos. A produção agrícola da maior parte dos Kalunga do Vão de Almas é a mandioca. Mas também produzem arroz, milho, feijão e abóbora. Porém esses últimos produtos apenas para sobrevivência de suas famílias e animais. Da mandioca, eles produzem farinha e tentam vender nos mercados da cidade com valor de $\mathrm{R} \$ 3$ a $\mathrm{R} \$ 5$ por quilo. No entanto, como todos produzem mandioca e fazem farinha, a oferta acaba ficando maior que a demanda e pouco lucro se consegue.

Nas entrevistas, a exceção de Seu Cirilo, não encontrei quem tivesse conhecimento sobre os programas governamentais de inclusão produtiva rural: Programa Cisternas, Programa de Aquisição de Alimentos, Fomento, Assistência Técnica Rural, ou qualquer outro programa de Segurança Alimentar.

Seu Zezinho inclusive sugeriu que o Governo comprasse a produção deles e entregasse para os hospitais, para pessoas que precisam e escolas. Quando eu disse a ele que esse programa existia, que se chamava Programa de Aquisição de Alimentos, seus olhos vibraram. Ele não conseguia acreditar que o Governo comprava alimentos de pequenos produtores e que eles não sabiam disso: "Se fosse uma prefeitura que quisesse ajudar a comunidade e comprasse os alimentos da gente, a gente podia até comprar uma placa solar, puxar uma água $[\ldots] "$

A única renda segura e certa da família de Seu Zezinho é o benefício do Programa Bolsa Família. Segundo Seu Zezinho, é a única política pública que eles viram chegar no Vão de Almas. "Esse é garantido", diz ele. O Bolsa Família, apesar de ser um benefício de baixo de valor, é o recurso que permite que eles se programem.

\footnotetext{
29 O Programa compra alimentos produzidos pela agricultura familiar, com dispensa de licitação, e os destina às pessoas em situação de insegurança alimentar e nutricional e àquelas atendidas pela rede socioassistencial, pelos equipamentos públicos de segurança alimentar e nutricional e pela rede pública e filantrópica de ensino. (Fonte: http://www.mds.gov.br/segurancaalimentar/aquisicao-e-comercializacao-da-agricultura-familiar)
} 
Segundo Dona Titinha, quando seu marido busca o dinheiro do Bolsa Família na cidade, ele compra alguns alimentos que eles não produzem. Ela relatou que o dinheiro do Bolsa Família é importante para a alimentação em especial na época da seca, quando não conseguem tirar o seu sustento da terra. Ela diz que "é pouco, mas já ajuda demais todo mundo. Ninguém mais passa fome no Vão de Almas."

Mas a comida comprada é vista com desconfiança quanto à sua qualidade. Com todos que conversei sobre a qualidade da alimentação, ouvi reclamação sobre os venenos colocados nas verduras, frutas, cereais e até mesmo na carne que eles compram. Rita disse que as comidas que eles plantam são as únicas que eles comem sem veneno: "Acho que hoje nós não temos mais segurança de nossa vida."

Dona Eva, que planta mandioca, milho e cria galinhas para seu sustento e de seus netos, também alertou para o cuidado que se deve tomar com a comida comprada por causa do veneno. Seu Albertino confirmou: “[...] a comida que a gente compra na cidade vem tudo envenenado". Mas seu Albertino se alegrou ao dizer que "a fome que tinha antigamente, essa Deus num deixa entrar mais".

Eu tive a chance de me alimentar nas casas de Dona Aimiram e de Dona Titinha. Cheguei na casa de Dona Aimiram, sem avisar previamente, no horário do almoço e fui convidada a almoçar: frango com açafrão, arroz, abóbora, feijão, quiabo, e pimenta feita por ela mesma. Ainda, de sobremesa, comi goiabas que sua neta apanhou no pé. A alimentação era farta e de boa qualidade.

$\mathrm{Na}$ casa de Titinha, ela relatou que o frango criado em seu quintal e o peixe pescado no rio ao lado de sua casa são as principais carnes consumidas, uma vez que eles não possuem geladeira para armazenar carnes, caso comprem na cidade, e não fazem criação de porcos. Quase não há consumo de verduras, a não ser a abóbora na época de chuva, mas a presença de farinha, arroz e feijão é certa, segundo ela. 


\section{8. É POUCO MAS TÁ BOM. O RUIM É NADA}

Conforme foi relatado no capítulo 1, o Programa Bolsa Família, em outubro de 2014, era acessado por 638 famílias quilombolas, dentre as 1.092 famílias quilombolas cadastradas no município de Cavalcante, representando somente $58 \%$ de alcance. Se compararmos ao município de Monte Alegre e Teresina de Goiás, onde $73 \%$ das famílias quilombolas cadastradas são beneficiárias do Bolsa Família, é possível concluir que aqueles residentes nas comunidades Kalunga dentro de Cavalcante ou possuem renda maior ou não estão sendo atendidos pelo Programa devidamente. A última opção é a mais provável.

Ainda assim, o Programa Bolsa Família foi relatado como o de melhor acesso pelos Kalunga nas comunidades do Engenho II, Vão de Almas e Vão do Moleque. Todos conhecem o Programa, apesar de não conhecerem as regras de elegibilidade, de distribuição de valores entre benefícios e de suspensão e cancelamento.

Muitos atribuíram ao Programa alguma melhoria de sua qualidade de vida, por ser um recurso financeiro garantido mensamente e disponível para livre uso.

Seu Zezinho, do Vão de Almas, relatou que antes do Bolsa Família, o dinheiro era só “de relar mandioca para vender farinha". Porém, a venda da farinha não era lucrativa e nem garantida, pois a atividade produtiva era comum a todos Kalunga, assim a oferta era muito para o comércio de Cavalcante, Teresina ou Monte Alegre. Ele contou com tristeza que havia meses que ficavam sem dinheiro nenhum.

Seu Zezinho utiliza o dinheiro do Bolsa Família, principalmente, para comprar chinelo para as crianças irem para a escola e cadernos, e algum alimento: “É pouco mas tá bom. O ruim é nada".

Porém, o dinheiro do Bolsa Família também precisa ser gasto com o transporte para a cidade. Seu Zezinho ganha R 170 de Bolsa Família e gasta R \$ 50 de passagem. Ele ainda precisa dormir lá na cidade por que o transporte vai em um dia e só volta no outro. O hotel mais barato custa R \$ 40 para solteiro: "Quando não tem nenhum amigo na cidade, eu tenho que ficar no hotel”. Então quando ele precisa pagar hotel, sobra somente R\$ 80. Dona Titinha falou decepcionada que o dinheiro "nunca sobrou para comprar umas coisas assim que tinha 
vontade. Coisas assim de casa mesmo que mulher gosta: um armário para pôr as roupas ou um colchão."

Apesar de o dinheiro ser considerado pouco, a disponibilidade de recursos financeiros para livre uso, no lugar de uma cesta de alimentos fechada e não regular, como eles costumavam receber, é bem avaliada pelos Kalunga. Porém, há insatisfação quanto à falta de entendimento sobre o Programa.

Na escola que visitei, houve uma grande discussão sobre o Programa com Dona Percília, a professora Irene e outros que estavam perto e que resolveram entrar na conversa. Dona Percília relatou que recebe o Benefício de Prestação Continuada - BPC ${ }^{30}$ por causa de um filho com deficiência e recebia o Bolsa Família, mas este foi cortado, e ela não entende por quê. Tentei ajudá-la ao perguntar se poderia ser por causa do salário mínimo recebido pelo filho que subiu a renda familiar.

Dona Percília não aceitou a explicação, pois disse não entender o motivo de outras pessoas receberem o Bolsa Família, mesmo tendo aposentados na casa. Nesse momento, uma roda de pessoas se juntou, e muitos tinham uma história para contar de gente que precisava e não recebia e de gente que não precisava e recebia. Ao final, ficou claro que não há entendimento sobre o cálculo do valor recebido por família. As regras do Programa não eram claras para eles.

A professora da escola desconhecia as regras da condicionalidade de educação do Programa. Quando perguntei à Professora Irene se na opinião dela as crianças tinham maior frequência na escola devido à condicionalidade de educação do Bolsa Família, ela respondeu que "tem uns que sim e outros que não". Sem entender, pedi que ela esclarecesse, e ela disse que muitos não cumpriam a exigência de frequentar $99 \%$ das aulas.

\footnotetext{
30 O BPC é um benefício da Política de Assistência Social, que integra a Proteção Social Básica no âmbito do Sistema Único de Assistência Social - SUAS e para acessá-lo não é necessário ter contribuído com a Previdência Social. É um benefício individual, não vitalício e intransferível, que assegura a transferência mensal de 1 (um) salário mínimo ao idoso, com 65 (sessenta e cinco) anos ou mais, e à pessoa com deficiência, de qualquer idade, com impedimentos de longo prazo, de natureza física, mental, intelectual ou sensorial, os quais, em interação com diversas barreiras, podem obstruir sua participação plena e efetiva na sociedade em igualdade de condições com as demais pessoas. Em ambos os casos, devem comprovar não possuir meios de garantir o próprio sustento, nem tê-lo provido por sua família. A renda mensal familiar per capita deve ser inferior a $1 / 4$ (um quarto) do salário mínimo vigente. (Fonte: http://www.mds.gov.br/assistenciasocial/beneficiosassistenciais/bpc )
} 
Ao explicar a ela que não era necessário frequentar $99 \%$ e sim $75 \%$, senti que ela ficou meio constrangida e justificou que, como não tinha filhos, não entendia nada do Programa, que se tivesse, ela estava mais atenta. Então ela disse que eles têm "umas faltinhas poucas, mas vem".

Como o Bolsa Família é um programa da assistência social, que tem entre suas responsabilidades acompanhar as famílias beneficiárias do Programa, perguntei a eles se já tinham ido ao Centro de Referência da Assistência Social- $\operatorname{CRAS}^{31}$ para entender os motivos dos cancelamentos, das reduções e diferenças de valores relatados por todos. Alguns não entenderam o nome CRAS, pois nunca tinham ouvido falar. Dona Percília disse que tinha ido, mas que o assistente social só informou a ela que o "sistema tinha cortado".

Não me causou surpresa, pois Titinha e Seu Zezinho, além de Rita do Engenho II, já tinham falado que nunca tinham ouvido falar do CRAS e que somente conheciam a Secretaria da Igualdade Racial. Nenhum morador relatou ter recebido uma visita de um assistente social. Quando eu perguntava, a reação era de estranhamento.

Seu Cirilo não é beneficiário do Programa Bolsa Família, mas informou que, no Engenho II, grande parte das pessoas que recebem o Bolsa Família o utilizam para comprar alimentos e material escolar: "O dinheiro ajuda muito". Seu Cirilo apresentou ter melhor conhecimento quanto à elegibilidade e distribuição de valores.

Quando falamos sobre o valor recebido pelo Bolsa Família, ele disse que tem gente que recebe até $\mathrm{R} \$ 800,00$ de benefício, mas foi logo explicando que isso se devia ao fato de a família possuir mais de oito filhos na casa. Perguntei se era comum as famílias Kalunga terem tantos filhos, e ele disse que não. Disse que houve um tempo sem ter muita criança na comunidade, mas, como agora os jovens estão ficando no Engenho II, a comunidade está em uma fase de muita "afilhação". Tentei entender se ele achava que o aumento do número de crianças poderia ser causado pelo valor do benefício do Bolsa Família, mas ele não fez essa relação em nenhum momento.

\footnotetext{
${ }^{31}$ O CRAS - Centro de Referência da Assistência Social: De acordo com a NOB-RH/SUAS, a composição das equipes de referência dos Estados para apoio a Municípios com presença de povos e comunidades tradicionais (indígenas, quilombolas e seringueiros) deve contar com profissionais com curso superior, em nível de graduação concluído em ciências sociais com habilitação em antropologia ou graduação concluída em qualquer formação, acompanhada de especialização, mestrado e/ou doutorado em Antropologia.
} 
Dona Getúlia, também do Engenho II, relatou que o Bolsa Família trouxe uma tranquilidade para as mulheres, tranquilidade que ela não teve no tempo em que criou que seus filhos. Ela informou que "naquela época era o tempo todo na roça, tinha que trabalhar muito para comer". As mulheres, segundo ela, não tinham como ter renda. Era preciso plantar tudo que fosse comer: "Não tinha dinheiro não, tudo que precisava tirava daqui". "Até roupa?", perguntei. "Até roupa", e ela me mostra fotos dela e de sua irmã fazendo tear. Elas plantavam algodão e faziam roupas e cobertas, mas, na época do frio, as roupas não eram suficientes.

“Hoje todo mundo é rico, não tem ninguém pobre”, disse Dona Getúlia. A pobreza que tanto castigou Dona Getúlia para criar seus filhos hoje alivia suas filhas. Suas filhas têm profissão. Duas são professoras na escola da comunidade. Outra é cozinheira do restaurante. Seus netos vão para a escola dentro da comunidade, têm material escolar, roupas e sapatos. Ninguém sofre mais por falta de dinheiro, segundo ela. Quem não tem um salário fixo que permite ter uma boa renda familiar, recebe o Bolsa Família, que beneficia principalmente as mulheres.

Ela então colocou as mãos no rosto e falou com muito entusiasmo que "a decisão mais acertada do Presidente Lula foi ter dado o cartão para as mulheres". Ela acredita que se fosse para os homens, o uso do recurso seria bem diferente. "Só quem sabe da necessidade de cada filho é a mãe. A mulher pode ter dez filhos e ela sabe do que cada um precisa, o pai não sabe.” Dona Getúlia dá um sorriso branco enorme e diz "por isso que eu amo aquele Lula. Ele pensou nas mulheres". Ela me diz que as casas que foram construídas no Engenho II foram colocadas no nome das mulheres, assim como a energia elétrica, o que provocou mudanças na cultura do território: "Antes quando a mulher queria se separar, ela tinha que voltar para a casa dos pais. Hoje a casa é dela. O homem que sai. Ela fica com a casa e com os filhos”.

Rita, do Engenho II, é beneficiária do Bolsa Família. Além disso, a família de Rita conta com a aposentadoria de sua mãe, com o Benefício de Prestação Continuada da sobrinha, que mora em sua casa e é portadora de deficiência, com a renda do trabalho de Rita como guia turística e com a renda de seu marido como pedreiro. Devido à pouca regularidade da renda, Rita chamou o trabalho dela e de seu marido de "bicos". 
Apesar de relatar ter despesas altas com tantos filhos, Rita disse que acha que vive bem: "eu não devo reclamar muito não, porque eu passei por dificuldade mais difícil, muito mais difícil e mais precária do que eu tô hoje. Hoje eu tenho que agradecer a Deus e me comparar, porque hoje eu sou uma pessoa rica pelo o que já passei. E muito obrigada", disse abrindo um sorriso.

Sendo beneficiária do Bolsa Família desde 2003, ela conseguiu possibilitar que seus dois filhos mais velhos terminassem o ensino médio. Ela diz que com o recurso ela comprava material escolar para seus filhos além de sandálias para irem à escola e algum item de alimentação. Falou com orgulho que acha que sempre fez bom uso do dinheiro, que a possibilitou comprar camas e colchão para cada um de seus filhos. $\mathrm{O}$ único mal uso que ela julga que pode ter feito foi a compra de um aparelho de DVD que seus filhos queriam. Mas ao mesmo tempo ela disse que acha que não foi mal uso, porque era o que seus filhos queriam. E ela tinha o dinheiro e comprou. Ficou feliz.

Rita então suspirou lembrando que só conseguiu comprar seu primeiro sapato aos 11 anos quando foi trabalhar. Lembrou de tudo que já passou e que felizmente seus filhos não precisaram começar a trabalhar tão cedo, pois ela os incentiva a estudar.

Segundo Rita, as crianças do território Kalunga normalmente ajudam os pais a trabalhar na roça ou fazer as tarefas de casa, mas estão todos indo para escola: "Aqui ninguém tira os filhos da escola para pôr os filhos para trabalhar". Primeiro, porque eles recebem o Bolsa Família e sabem que têm de cumprir a condicionalidade. Segundo, porque: "Quem sofreu o analfabetismo sabe o quanto dói. Por isso nenhuma mãe ou pai faz isso. Tem muitos pais e mães analfabetos nessa nossa região e eles sabem o quanto dói a gente ser analfabeto". 


\subsection{SER ANALFABETO DÓI}

Rita (figura 38) olhou bem dentro dos meus olhos e falou várias vezes o quanto dói ser analfabeto como quem pensa "você não sabe do que eu estou falando, preciso repetir para você entender". Ela então repetiu "ser analfabeto dói". Contou que às vezes é chamada para uma reunião e as pessoas distribuem algum papel explicando o motivo da reunião, mas como ela não sabe ler, ela fica só segurando o papel ao invés de ler e prestar atenção.

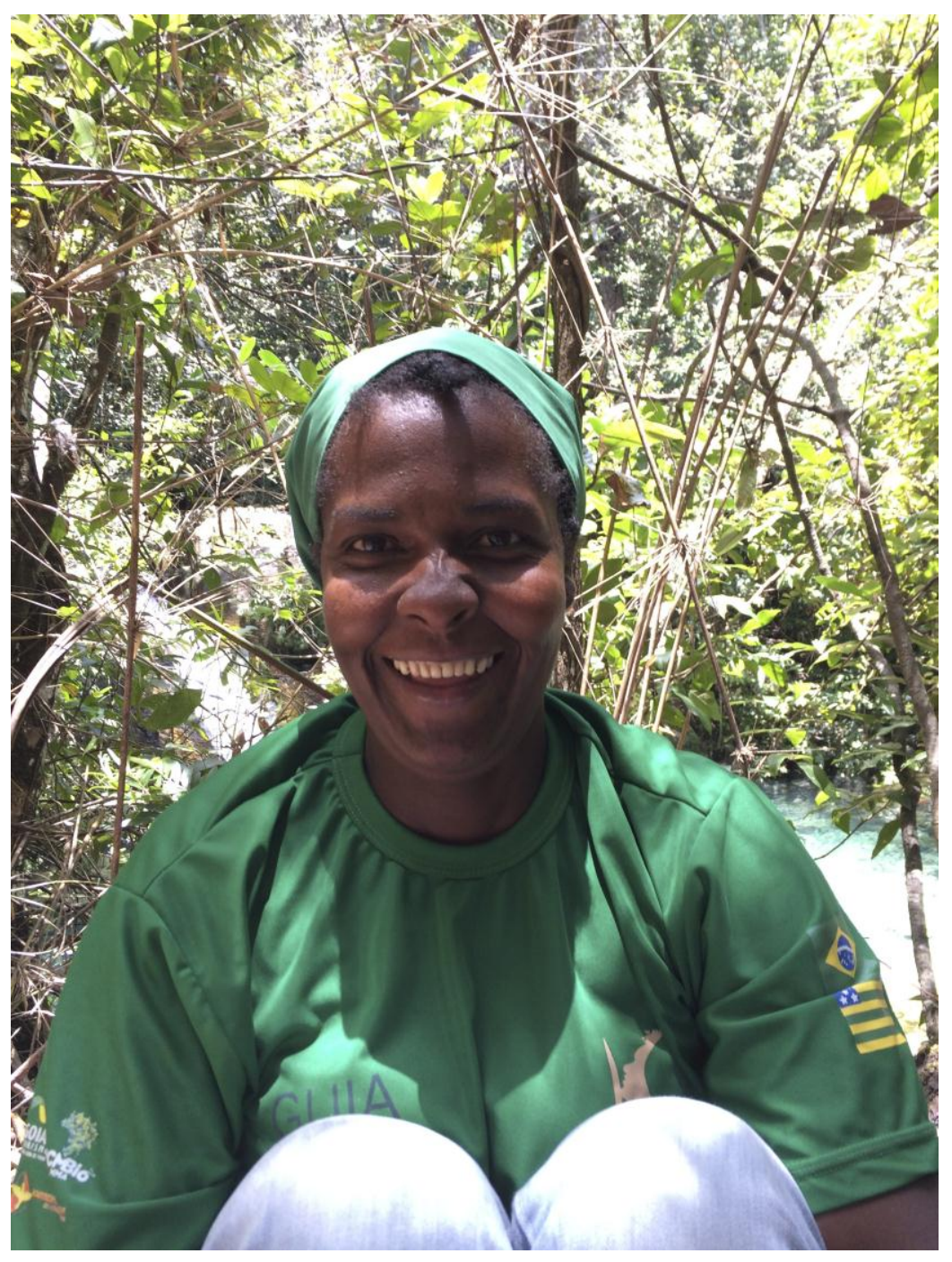

Figura 38: Rita, guia turística do Engenho II, fev. 2015. Fonte: a autora.

Ela relatou comprar produtos vencidos no supermercado por não saber ler a validade. Já passou por momentos de constrangimento em mercados e mercearias da cidade por não 
saber ler o preço dos produtos. Ao perguntar: “Quanto que custa essa garrafa d'água?”, ela ouviu o atendente rispidamente informar, "o preço tá bem aí na parede". Indignada, ela continuou: "eu tô vendo o preço ali mas se eu não sei quanto que é, o meu direito é de perguntar". Ela afirma novamente, me olhando com força nos olhos, "é muito doído".

A realidade de Rita é vivenciada por grande parte dos moradores do território Kalunga. A Pesquisa do MDS mostrou que, em 2011, 44,1\% dos moradores do território Kalunga eram analfabetos e $29,9 \%$ tinham o ensino fundamental incompleto. No entanto, espera-se que no futuro esse quadro mude, pois com todos que conversei, há consenso sobre a importância de os filhos frequentarem a escola.

Rita reafirma que hoje ninguém precisa tirar os filhos da escola para trabalhar. Em sua opinião, além de as oportunidades serem mais raras no passado, os pais não achavam que os filhos iriam sofrer por não ter estudos. "Os povos de antepassado só pensava em morrer, eles não pensava no futuro".

Porém, Rita valoriza o conhecimento. Afirmou que, apesar de ser analfabeta, aprendeu muito com o mundo: "O mundo foi meu caderno e minha caneta". Ela não frequentou a escola quando criança e sempre priorizou trabalhar para criar seus filhos sem que eles passassem a fome que ela passou. Falou do quanto doía ver sua mãe ter que pedir comida para os vizinhos para seus filhos se alimentarem: "Desde que eu fui mãe, a coisa que eu mais foquei foi trabalhar para os meus filhos, para eu não depender de pedir uma bocada de comida para ninguém. Eu odeio pedir.”

Todos os filhos de Rita frequentaram ou frequentam a escola. Dois já terminaram o ensino médio, fizeram concurso para trabalhar em Goiânia e passaram. Contou com muito orgulho que sua filha de 18 anos passou no vestibular para cursar serviço social. Porém, a faculdade é particular e ela não sabe como sua filha irá pagar a faculdade, pois seu salário não é suficiente.

Os filhos menores de Rita moram em Cavalcante para estudar, pois Rita acha que o ensino dentro do Engenho II não é tão bom. Ela acredita que eles terão uma vida melhor se forem para a cidade logo cedo. Então, ela tem uma casa em Cavalcante (não ficou claro se é 
alugada ou se é própria) para sua mãe, sua sobrinha deficiente e seus filhos, pois assim sua mãe fica mais próxima da assistência médica.

Apesar de Rita ter optado por mandar seus filhos para a cidade para estudar, no Engenho II, onde ela mora, há escola de ensino fundamental I e II e de ensino médio. Dona Getúlia considera que o ganho maior da inserção de políticas públicas no território Kalunga "é o direito de estudar na sua própria comunidade".

Ela falou com muito orgulho que os Kalunga movimentaram-se e levaram a escola do ensino médio para sua comunidade com o apoio da Fundação Cultural Palmares e do MEC, que os instruíram nos modos de demanda e de concretização da escola. Eu percebo a felicidade dela de, mesmo percebendo a importância das instituições, sentir que os Kalunga são protagonistas no processo de desenvolvimento.

Seu Cirilo compartilha do orgulho de Dona Getúlia de terem o ensino médio dentro de sua comunidade. Ele disse que antes de 2004, as meninas e meninos de 14 anos tinham que ir para a cidade, trabalhar ou estudar. Hoje, "com o desenvolvimento, o ramo de vida é melhor aqui [...] tamo sendo autossustentável aqui. Quem saiu, quer voltar."

De acordo com Seu Cirilo, os jovens migram somente quando fazem faculdade. "Muitos deles estão fazendo (faculdade) e depois voltam para a comunidade para dar aula". Dos doze professores que lecionam na escola do Engenho II, dez são Kalunga. Os outros dois não são Kalunga, mas moram na comunidade por serem casados com Kalunga. Os merendeiros e faxineiros também são da comunidade.

Segundo Seu Cirilo, as crianças também têm aulas de reforço escolar no horário contrário à aula regular pelo Programa de Erradicação do Trabalho Infantil - PETI. Na época de escola, não vão para as roças, apesar de ter "criança que fica chorando para ir para a roça. Gostam de ficar lá comendo cana, banana, correndo...”. Segundo ele, as crianças estão livres do trabalho infantil, porque todos sabem que têm de estudar, e seus pais não querem perder a Bolsa Família. Enquanto conversávamos, vi algumas crianças de cerca de 10 anos de idade correndo subindo uma serra do restaurante. Perguntei a ele o que eles faziam. Ele somente respondeu: "Brincando. Esses meninos quando não estão na escola brincam o tempo todo correndo por aí". 
Porém essa não é a realidade do Vão de Almas e do Vão do Moleque, onde há somente ensino fundamental, onde a merenda escolar não é regular, onde não há professores suficientes, e de onde os jovens saem aos 14 anos e para onde poucos retornam.

O problema maior para os jovens do Vão de Almas e do Vão do Moleque começa no ensino médio, quando precisam ir para Cavalcante. Muitas meninas vão trabalhar em casa de família para ter onde morar e poder estudar. Outros ficam em casa de parentes, irmãos mais velhos, que já estão lá. Em seguida, de Cavalcante, grande parte dos jovens vão para Brasília e Goiânia trabalhar ou estudar, e não voltam mais.

Os cinco filhos de Dona Aimiram estão fora do território. Dois de seus filhos estão fazendo faculdade, uma está cursando licenciatura na UnB e outro administração em faculdade particular. Os outros estão trabalhando.

Seu Mochila acha que a implantação de uma escola de ensino médio agrícola dentro do Vão do Moleque seria fundamental para a permanência dos jovens no território. Ele contou que todos seus filhos trabalham na cidade de Brasília. Mas ele considera que eles moram no Vão do Moleque, pois na cidade estão em casa alugada, e isso para ele não é morar. Dona Iva, esposa de Seu Mochila, que havia permanecido calada em toda a nossa conversa, nesse momento interrompe seu silêncio e diz que os jovens vão "porque querem aprender, observar alguma coisa".

Mas Seu Mochila não considera que seus filhos estão progredindo em Brasília, pois eles ganham somente um salário mínimo, e eles poderiam estar dentro do território trabalhando e ganhando mais como professor ou enfermeiro, por exemplo. "Se for indo, e nós não achar uma categoria e eles não voltarem para cá, não vai sobrar ninguém aqui. Por que vamos todos morrer."

Ele então diz que se de dez jovens que saíssem, cinco voltassem, já seria suficiente para manter o território Kalunga vivo. "Os jovens que se formam têm que voltar para trabalhar pela melhoria de sua comunidade", pensa Seu Mochila. "Eles têm que aprender a ganhar dinheiro no lugar deles". 
Na casa de Seu Zezinho e Dona Titinha no Vão de Almas, há grande preocupação quanto à saída dos jovens da comunidade. Eles têm dois filhos adolescentes de 15 e 16 anos e outras duas crianças de 12 e 9 anos. Seus outros dois filhos maiores já estão em Brasília trabalhando. A filha, hoje com 22 anos, casou-se aos 17 anos e mudou-se com o marido. $\mathrm{O}$ filho, hoje com 23, ainda não se casou, mas teve que se mudar para arrumar um emprego, pois ali, segundo Titinha, eles não têm opção de trabalho ou de seguir com os estudos. Ambos pararam de estudar no $9^{\circ}$ ano, pois este é o máximo que se pode estudar dentro do Vão de Almas.

Dona Titinha e Seu Zezinho já estão preocupados com os dois filhos de 15 e 16 anos, que estando no $9^{\circ}$ ano, terão que se mudar no próximo ano. Eles não têm onde morar na cidade de Cavalcante para cursar o ensino médio. Seu Zezinho não gostaria que sua filha se casasse somente para sair de casa e ir trabalhar, gostaria que ela seguisse com seus estudos, e deseja o mesmo para seu filho. Dona Titinha vê a possibilidade de sua filha ir trabalhar em uma casa de família, onde ela pudesse morar e trabalhar, mas não sabe como seu filho faria. Seu Zezinho acha que o destino de sua filha é se casar cedo, pois é muito difícil para eles sustentarem os filhos na cidade para estudar: "Elas têm vontade de estudar, mas terminou o estudo (no $9^{\circ}$ ano) e fica aí fazendo o quê? Então elas têm que arrumar um marido para sair de casa e trabalhar."

Titinha diz que, apesar da saudade que sente das crianças, ela gostaria que seus filhos que hoje têm 14 e 15 anos saíssem para estudar o ensino médio: "Eu queria que eles estudassem para ter um emprego bom. Tem que arrumar uma casa de uma pessoa que eles fica e trabalha e já estuda. Para as meninas é mais fácil, mas para os meninos é mais difícil, pois eles não têm como arrumar emprego nas casas."

A falta do ensino médio expulsa os jovens Kalunga de seu território. Após saírem para buscar emprego e estudos, encontram uma vida na cidade, que apesar de menos generosa com seus habitantes em termos de beleza natural e vida saudável, apresenta um estilo de vida com um mínimo de infraestrutura, como energia elétrica e água encanada, e eles não querem mais voltar.

A Professora Irene, de 25 anos, estudou o ensino fundamental no Vão de Almas e fez o ensino médio em Cavalcante. Ela, no entanto, quis voltar para o Vão de Almas. Com 
formação de ensino médio, leciona na escola por contrato temporário. Sabendo da exigência do MEC de o professor ter ensino superior para lecionar até mesmo no ensino fundamental, ela tratou logo de se justificar que, como tem poucos professores disponíveis para lecionar no Vão de Almas, eles aceitam professores somente com ensino médio. E relatou suas tentativas frustradas de entrar no Programa Educação do Campo na Universidade de Brasília - UNB.

A Pesquisa do MDS apontou que em 2011 somente 0,3\% dos moradores do Vão tinha curso superior completo. Espera-se também que, com o Programa Educação no Campo, os Kalunga consigam aumentar sua escolaridade. O presidente da Associação Quilombo Kalunga relatou ter feito a graduação no Centro de Desenvolvimento Sustentável da UNB, e que pretende fazer o mestrado. Ele relatou que cerca de 100 moradores do território Kalunga estão fazendo graduação pelo referido Programa, uma dessas pessoas é a mãe de Irene, também professora em escola no Vão de Almas, que já vai se formar em pedagogia no mês de março.

No entanto, a precária estrutura de algumas escolas (figura 39), a irregularidade da merenda e do o transporte escolar, a ausência de bibliotecas e outros incentivos para o estudo são elementos que prejudicam a qualidade do ensino no território.

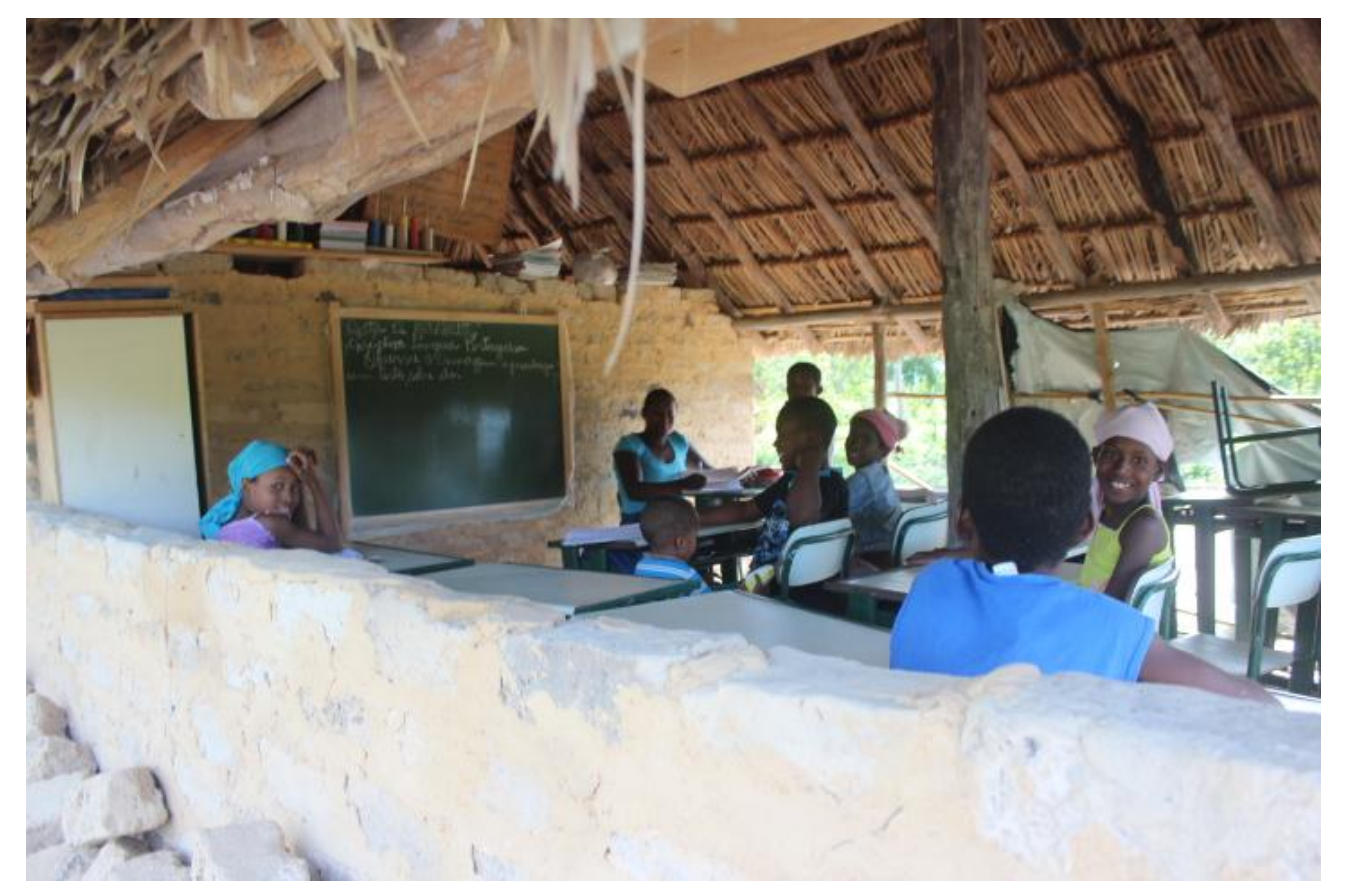

Figura 39: Escola no Vão de Almas, mar. 2015. Fonte: Beto Baiano. 
Havia 10 dias que a merenda escolar do município estava em falta. Quando isso ocorre, Dona Persília e Irene dizem que não há muito o que fazer, e as crianças ficam com fome, pois somente alguns trazem lanche de casa. A única solução encontrada pela escola é dispensá-los mais cedo. Dona Persília informou ser normal eles ficarem 2 ou 3 meses no ano sem merenda; então, eles têm aula somente de 7 h30 às 9 h30 ou 10 h.

As turmas são multiseriadas: primeiro ano junto com pré 3, segundo com terceiro ano, quarto com quinto ano, sexto com sétimo ano. Segundo ela, a maioria das crianças que terminam o nono ano na escola dentro do Vão querem sair para poder continuar os estudos. Mas, nas palavras da Professora Irene, "é difícil demais". Eles sonham também em fazer faculdade, de acordo com a professora. "Cada um fala uma coisa que quer ser". A Professora Irene diz que seu sonho sempre foi ser professora. Agora, “com fé em Deus”, diz ela, "eu vou fazer faculdade".

A Professora Irene diz que não gostaria de sair do território Kalunga. Ela gostaria de obter o ensino superior e atuar em seu território como professora. Quando perguntei por que ela gostava de morar lá, a resposta dela foi parecida com a de quase todos para quem perguntei isso: "Nasci e criei aqui. Eu gosto de ficar aqui." 


\subsection{BOM FICAR É NO LUGAR ONDE A GENTE NASCEU E CRIOU E CONHECE}

Com todos que conversei, a primeira pergunta era, "Você nasceu aqui?" e quase todos respondiam, "Nasci e criei aquil". Ao final da conversa da conversa eu perguntava, "você tem vontade de sair daqui?" e todos respondiam que não, e a razão sempre era "por que eu nasci e criei aqui".

Quando fiz a pergunta a Dona Getúlia, ela me disse que nasceu ali, viajou muito e voltou. Voltou e não sai dali nunca mais. Ela contou que saiu por que tinha que conhecer outros lugares e outras pessoas, e estudar um pouco, mas que o clima dali, a água dali, ela não esquecia. "Bom ficar é no lugar onde a gente nasceu e criou e conhece".

Seu Mochila relatou toda a sua trajetória de vida no território Kalunga e entristece-se pelo fato de os jovens estarem indo embora.

Seu Mochila tem consciência que a permanência de seu povo no território quilombola é condição para a formação do espaço Kalunga. Segundo ele, sem o homem, sobra apenas a terra. Ele teme que se eles não mais estiverem ali, ou mesmo se eles forem poucos, a terra ficará à disposição para exploração pela mineração em poucos anos.

Com todos que conversei, percebi o orgulho de ser Kalunga nos elogios à paisagem formada pelos recursos naturais em sua grande parte, ao clima, ao solo e ao seu povo.

Seu Albertino logo me avisou: "A senhora pode vir aqui com sua barraquinha e colocar aqui, que ninguém mexe em nada." Ele então contou sobre uma série de pessoas, inclusive citando nomes, que estiveram no Vão de Almas, provavelmente pesquisadores, e passaram muito tempo lá e que sempre voltavam porque gostavam.

Ele diz que todo mundo adora o Vão de Almas por causa do sossego encontrado: "Só a tranquilidade que tem aqui!". Ele então relatou o que viu e sentiu em sua viagem a Goiânia, onde teve que ir fazer exames, e diz que "nunca viu tanta tristeza no mundo". 


\subsection{1. É O LUGAR MAIS ESQUECIDO É O NOSSO VÃO DE ALMAS. MUITA GENTE DE FORA VEM AQUI, PARTICIPA DE NÓS, USA O NOME DE NÓS, LEVA LÁ PRA FORA, E NUNCA QUE CHEGA NADA}

Os Kalunga têm amor por seu lugar, preservam e lutam por ele. Porém, parecem estar desacreditados do poder público e da ação externa. Seu Albertino, quando introduzi o tema de políticas públicas no território Kalunga para iniciarmos a conversa já foi logo me avisando: "é o lugar mais esquecido é o nosso Vão de Almas. Muita gente de fora vem aqui, participa de nós, usa o nome de nós, leva lá pra fora, e nunca que chega nada".

Com todos que conversei, houve certa desconfiança quanto a razão de eu estar ali. Pois até mesmo a relação com pesquisadores parece estar abalada. Quando pedi a Seu Mochila, do Vão do Moleque, para conversar sobre a pesquisa, ele disse logo: "não gosto de pesquisador". Beto, meu guia, tratou logo de informá-lo que eu trabalhava no "Ministério que tem o programa Cisternas". Então seu Mochila abriu um sorriso: "Aí eu gostei. Eu gosto de conversar com gente que sabe das coisas". Claro que logo tratei de esclarecer que eu não estava ali em nome do Ministério, e sim por causa da minha pesquisa na Universidade. Então ele diz, "é mas como você trabalha lá no Ministério, quem sabe cê fala para eles lá como é que a gente vive aqui". Senti o peso nas costas ao ver a esperança depositada em mim, mas disse a ele que a informação e a visibilidade trazidas pelas pesquisas acadêmicas são de fato fundamentais para a política pública.

O relato mostra que Seu Mochila ainda tem certa confiança no Governo Federal. Isso foi observado em várias conversas. Seu Zezinho, do Vão de Almas, disse que não entende para onde vai o dinheiro do Governo Federal que sai para os Kalunga. Ele acredita que o Governo Federal acha que eles já têm energia elétrica, por isso não faz nada.

Ele afirmou categoricamente que o Governo Federal já mandou esse dinheiro, mas que a prefeitura, em suas palavras, "deu sumiço". "Para onde foi o dinheiro? Ninguém sabe. A gente só sabe que o povo da prefeitura vai ficando rico."

A descrença quanto ao poder local é tão intensa que Seu Zezinho sugeriu que o Governo Federal acabasse com as prefeituras e criasse uma "instituição que atendesse as famílias, que conhecesse os problemas que as comunidades passam”. Eu disse que este era o 
papel das prefeituras. "É, não é?", disse ele incrédulo. No entanto, acredita que o Governo Federal possui meios de atender o território Kalunga: "Programa ês (eles, referindo-se ao Governo Federal) tem né, mas num vem pra cá.”(...)

A informação sobre recursos enviados pelo Governo Federal ao município de Cavalcante foi recorrente em nossas conversas, sempre trazida pelos Kalunga. Rita, moradora do Engenho, sabe que todo o dinheiro que entra na prefeitura está em um site (Portal da Transparência $^{32}$ ). Apesar de não lembrar o nome do site, ela sabia informar que o município de Cavalcante não prestava contas do dinheiro. Falou sobre a existência de alguns projetos do Governo Federal para Cavalcante: "Ninguém nunca viu esse dinheiro. Para onde esse dinheiro foi? Se ele veio, ele parou aonde? Na prefeitura".

Seu Albertino também apresentou imensa desconfiança em relação ao município: "Prefeito só gosta de nós na hora do voto. Votou, virou as costas e babau viola, num olha mais pra trás".

Os Kalunga votam e sabem o valor do seu voto, apesar de não acreditarem nas pessoas que estão no poder: "na hora do voto, eles procuram a gente, depois somem" [...] "Eu até falei que quando tivesse uma eleição, ninguém votava. [...] Kalunga só tem valor na hora do voto, depois, votou, acabou", reclamou Dona Persília indignada.

Mas os Kalunga têm consciência da relevância do exercício de sua cidadania por meio do voto, seja para prefeito, vereadores, ou até mesmo presidente de sua associação.

A ${ }^{33}$ Associação Quilombo Kalunga - AQK (figura 40), associação que abarca as associações Kalunga de cada município (Cavalcante, Monte Alegre e Teresina) elegeu novo presidente em início de 2015. A participação popular foi incentivada para fortalecer o coletivo, relatou Vilmar Sousa, o novo presidente eleito. Segundo ele, 790 pessoas votaram na eleição ocorrida no final de 2014.

\footnotetext{
32 O Portal da Transparência do Governo Federal é uma iniciativa da Controladoria-Geral da União (CGU), lançada em novembro de 2004, para assegurar a boa e correta aplicação dos recursos públicos. O objetivo é aumentar a transparência da gestão pública, permitindo que o cidadão acompanhe como o dinheiro público está sendo utilizado e ajude a fiscalizar. Fonte: http://www.portaltransparencia.gov.br

${ }^{33}$ quilombokalunga.org.br
} 
A sede da AQK, em Cavalcante, funciona meio período para atendimento aos Kalunga, que a procura para resolver questões individuais, como acesso ao salário maternidade, e coletivas, como a manutenção da estrada para o Vão do Moleque.

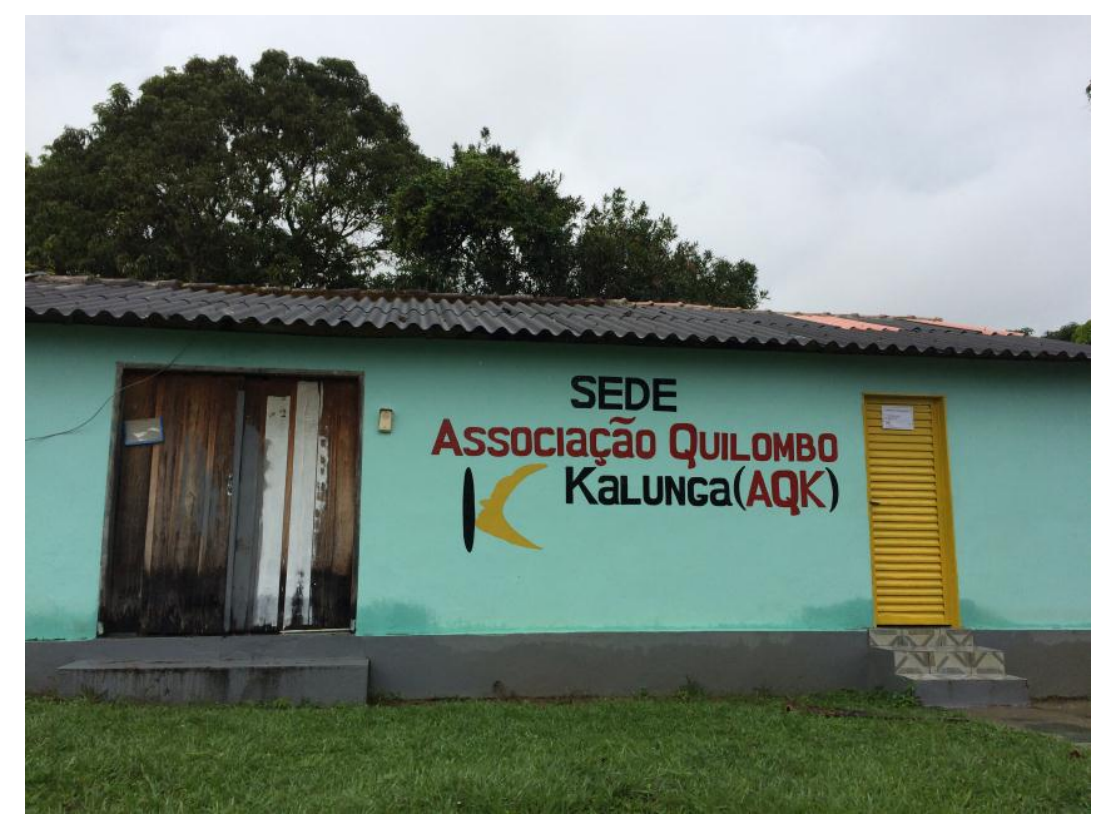

Figura 40: Sede da Associação Quilombo Kalunga em Cavalcante, mar. 2015. Fonte: a autora.

A AQK, fundada em 1999, tem experiência com alguns projetos. Foi citado um projeto pactuado diretamente com a Petrobras, "Kalunga Sustentável", no valor de R\$1,3 milhão. Além disso, a AQK foi contratada pela Caixa para execução da construção das casas por meio de parceria com a FUBRA-UNB para o programa de habitação quilombola. Segundo Vilmar, o Programa Nacional de Habitação Rural - PNHR está em contato com a associação para uma nova etapa de construção de casas populares no território.

Tanto Dona Aimiram, como seu Zezinho e Seu Mochila relataram participar das reuniões da associação. Porém, a grande reclamação dos moradores do Vão de Almas e do Vão do moleque é a falta de investimento da associação nesses lugares. Segundo eles, o recurso arrecadado na portaria do Engenho II, devido ao turismo nas cachoeiras, são da associação. Os moradores do Vão do Moleque gostariam que associação investisse na manutenção da estrada entre o Engenho II e o Moleque. Os moradores do Vão de Almas gostariam que a associação utilizasse o recurso para encanar água para as casas do Vão, "para ajudar o povo". 
A motivação para lutar por seus direitos é grande entre os Kalunga. Dona Aimiram, do Vão do Moleque, relatou que eles formaram uma caravana para ir à posse da Presidente Dilma e que levaram suas principais reinvindicações à SEPPIR: água, estrada e energia.

Os Kalunga, por serem guerreiros, continuam lutando. Apesar da lentidão do Estado brasileiro, ele acreditam que as políticas públicas podem trazer a eles oportunidades de inclusão, de geração de renda, de bem estar social e autonomia:

"Já que começou a melhorar, vamos botar os Kalunga nos planos né gente, não deixa a gente lá no fundo não. Por que os Kalunga também é gente também [...]Eles são é preto, mas tem o mesmo sangue. E é trabalhador. Por que nós nasceu e criou carregando madeira nas costas para fazer nossa roça e criar nossos filhos". (Seu Mochila, fevereiro de 2015) 
"Esse lugar aqui é um lugar muito ótimo para nós. Nascemos e criamos aqui nessa terra.

Nós tem amor por ela. Meu bisavô morreu nela, meu avô morreu nela, meu pai morreu nela e eu vou morrer nela. E eu queria largar para meus filhos. Essa terra é uma terra amada por Deus. Só larga ela quem não tem bondade."

Seu Mochila (Joaquim Moreira da Silva), 70 anos, 10 filhos

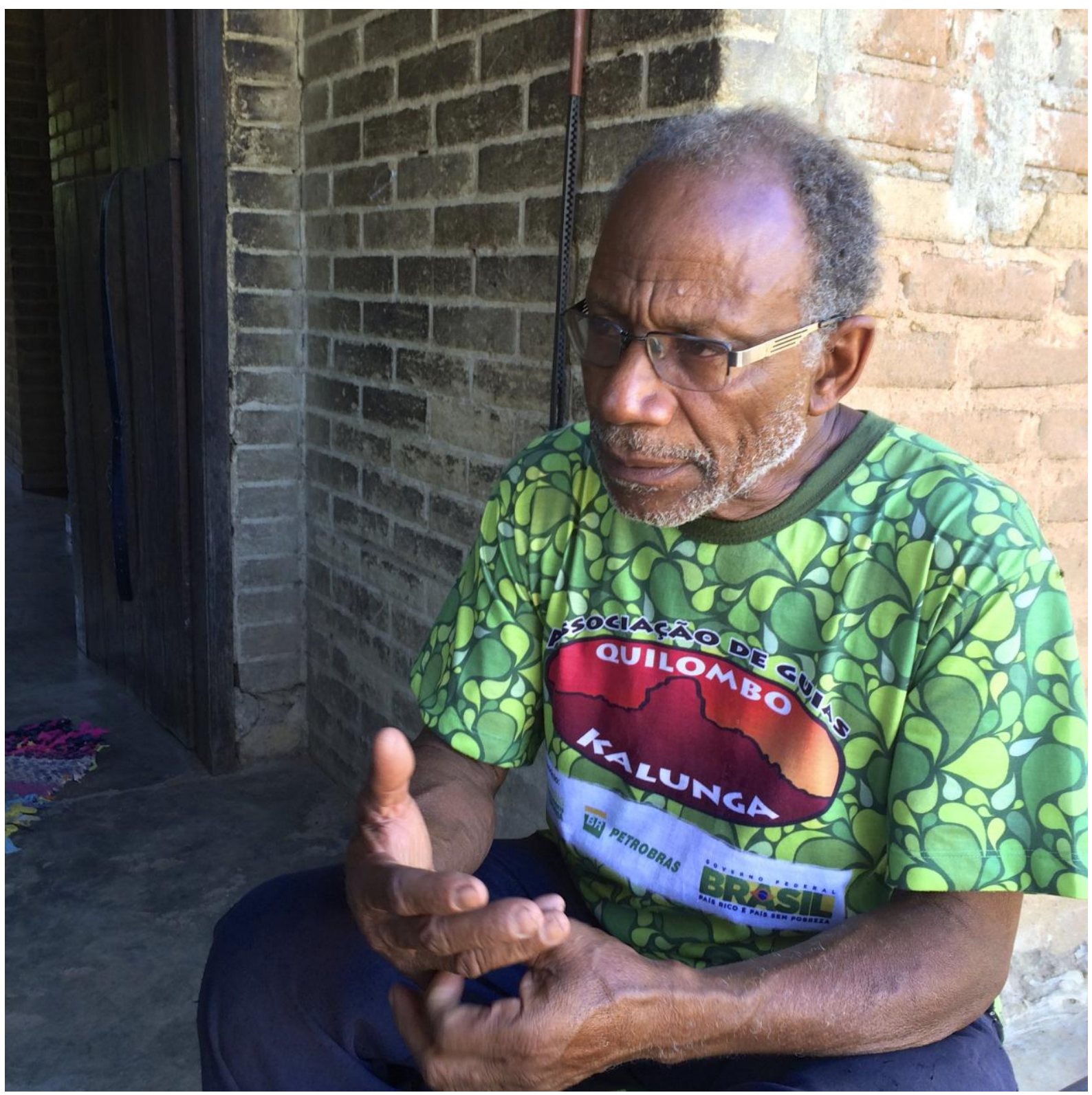




\section{CONSIDERAÇÕES FINAIS}

\section{EU GOSTO É DE FOTO VIVA}

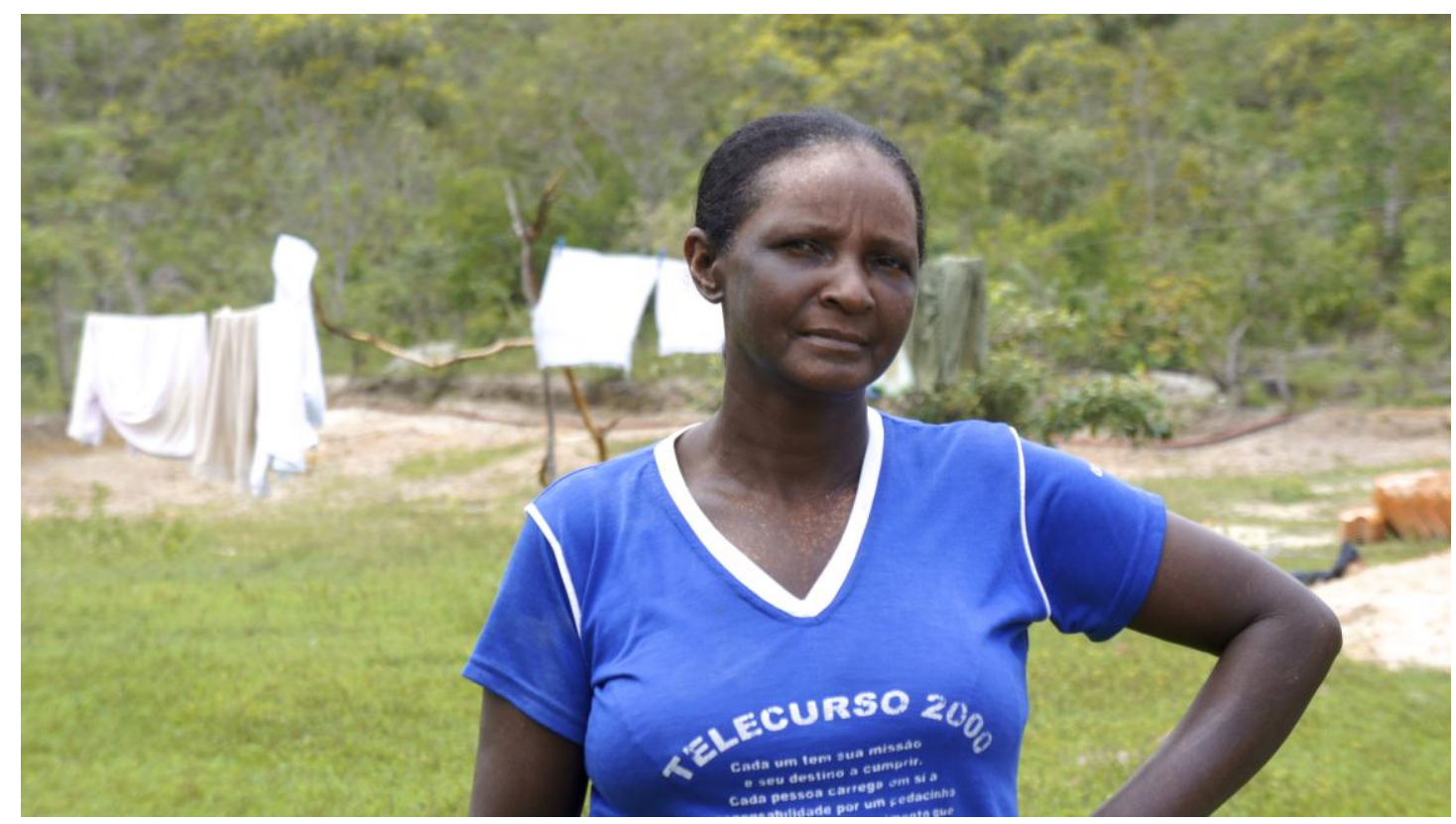

Figura 41: Dona Getúlia, do Engenho II, fev. 2015. Fonte: a autora.

Pedi para tirar uma foto de Dona Getúlia (figura 41) em sua casa, onde estávamos conversando, e ela me olha seriamente. Quando penso que ela vai dizer que não gosta de foto, ela me diz: "Eu gosto é de foto viva." Eu, sem entender, olho para ela e pergunto como seria a "foto viva". Ela diz: "Com o verde. Vamos tirar lá fora, de frente para aquela serra ali, que é bonita".

E era de fato uma serra linda, mas o conjunto formado pela serra, a mulher Kalunga, sua vivência no território, os objetos geográficos naturais e artificiais ali encontrados nos proporcionou de fato uma "foto viva". E esse foi o grande ganho da pesquisa de campo.

Os indicadores da Pesquisa do MDS nos permitem ter uma fotografia, uma visão em escala do espaço Kalunga, em um determinado momento, mas a fotografia somente ganhou vida quando a voz dos Kalunga fizeram a união de som e imagem. A foto ficou viva e deixou transparecer o significado de sua história, a riqueza da vida e da experiência desse povo. 
Santos (2006, p. 214) nos disse que "uma dada situação não pode ser plenamente apreendida se, a pretexto de contemplarmos sua objetividade, deixamos de considerar as relações intersubjetivas que a caracterizam". A disputa de poder pelo território, o apoderamento do território pela vivência de gerações após gerações, a interferência dos agentes globais e os agentes locais, a resistência e a luta pela existência, são elementos que somente os Kalunga poderiam revelar.

Mesmo tendo procurado aprofundar as questões por meio de longas conversas e observação, estão em jogo as diversas interpretações possíveis feitas pelo pesquisador e as diversas proporções de compartilhamento realizadas pelos pesquisados. Lefebvre (1971, p. 28, apud SANTOS, 2006, p. 214) afirmou que "a análise da vida cotidiana envolve concepções e apreciações na escala da experiência social em geral". Portanto, a compreensão dos efeitos das políticas públicas no desenvolvimento Kalunga parte da análise desta pesquisadora sobre o lugar e o movimento da totalidade no território Kalunga, mas sem desconsiderar conhecimentos prévios sobre esperados efeitos para os programas sociais.

Uma pergunta que permeou a pesquisa foi: que significado tem hoje o lugar Kalunga, que um dia significou a única oportunidade de trabalho livre e de liberdade? O Estado brasileiro, por meio de políticas públicas, tem proporcionado o aumento das liberdades globais para que os Kalunga levem o modo de vida que eles com razão valorizam (SEN, 2010)?

Com a titulação do território quilombola, a principal reinvindicação das comunidades quilombolas no Brasil, a comunidade Kalunga ganhou maior visibilidade frente ao poder público e sente que o reconhecimento de sua identidade como quilombola trouxe o fortalecimento de sua cidadania. Apesar de a opinião geral ser de que houve alguma melhoria de qualidade em sua vida, o desenvolvimento dentro da comunidade se apresenta de maneira desigual, conforme relatado nos capítulos anteriores.

As diferenças de acesso a programas governamentais são percebidas nas paisagens do Engenho II, do Vão do Moleque e do Vão de Almas. O Engenho II traz a paisagem transformada pelas políticas públicas, enquanto o Vão de Almas e o Vão do Moleque apresentam uma paisagem quase que natural. Não é completamente natural pelo fato de os próprios Kalunga terem ação sobre o espaço. 
Percebe-se na paisagem do Engenho II uma multiplicidade de disposição de formas e atores sociais integrantes de uma vida social mais complexa: centro de atendimento a turistas, loja de produtos sustentáveis Kalunga, restaurantes, pousadas domiciliares, postes de energia nas ruas, escolas de ensino fundamental e médio e posto de saúde. Logo, percebe-se que o espaço no Engenho II foi modificado pela inserção de políticas públicas de infraestrutura e de provisão de serviços públicos essenciais.

Já no Vão de Almas e no Vão do Moleque, a paisagem revela a ausência de políticas públicas estruturantes. Andando por esses lugares percebe-se a carência de acréscimos à natureza que os priva do circuito sistêmico de produção. Santos (2014, p. 72). destaca que os instrumentos de trabalho imóveis como energia elétrica, água, telefone, estradas e pontes "estão ligados ao processo direto da produção, isto é, à produção propriamente dita, também o estão à circulação, distribuição e consumo"

Santos (2014) ressalta que as formas envelhecem física e socialmente, por inadequação, por desuso, desvalorização e preferência a novas formas. As formas envelhecidas das casas de adobe, das estradas cheias de buracos e valas, do chão de areia dentro de casa, entristecem os Kalunga, que clamam por formas novas, desde simples banheiros com chuveiro e água quente a pontes sobre os córregos.

A acessibilidade e a mobilidade entre os povoados e para fora do território Kalunga são prejudicadas pela ausência de duas antigas políticas públicas: construção de estradas e pontes e fornecimento de transporte público. Os moradores do Vão de Almas e do Vão do Moleque veem a estrada e o transporte como possibilidades de conexão deles com outros mercados que possam lhes garantir liberdade econômica, que lhes gerem oportunidades sociais. Cientes de que a privação de liberdade econômica, retratada nos indicadores de pobreza extrema e nos relatos de luta pela sobrevivência, os tornam indefesos perante a violação de outros tipos de liberdade (SEN, 2010), os Kalunga não aceitam que o Estado os deixem à margem do desenvolvimento. O relato de Seu Albertino, que enfrentou o "cabra chefe do IBAMA" para que a estrada do Vão de Almas não fosse embargada e o relato de Dona Aimiram sobre o mutirão formado dentro do Vão do Moleque para angariar recursos e pagar um trator para minimamente consertar a estrada, descritos do capítulo 3 desta dissertação, mostram que os Kalunga lutam e resistem ao descaso do poder público quanto às necessidades que ainda se fazem presentes. 
Com a precariedade das estradas e a escassez de transportes de ligação entre o Vão de Almas e o Vão do Moleque e a cidade de Cavalcante, a distância entre os diversos povoados da comunidade Kalunga e entre esta e o meio urbano se torna ainda maior. Santos(2006, p.216) fala da importância da proximidade para a "totalidade das relações":

Mas a proximidade que interessa ao geógrafo [...] não se limita a uma mera definição das distâncias; ela tem que ver com a contiguidade física entre pessoas numa mesma extensão num mesmo conjunto de pontos contínuos, vivendo com a intensidade de suas inter-relações.

A contiguidade entre os Kalunga dentro do território é garantida somente pelo o que os une: o lugar, como espaço do acontecer solidário. Seus laços culturais, como as festas religiosas, a sussa e as rezas nas casas, seus conhecimentos passados de geração em geração sobre os cursos dos rios, os períodos das chuvas, o uso do solo, o uso medicinal de plantas e frutos do cerrado, a confecção da farinha, a fé em Deus e o amor pelo lugar onde todos ali “nasceram e criaram" são o que os torna uma grande comunidade.

É no lugar onde a política se materializa, confrontando a organização e a espontaneidade:

\begin{abstract}
No lugar - um cotidiano compartido entre as mais diversas pessoas, firmas e instituições - cooperação $e$ conflito são a base da vida em comum. Porque cada qual exerce uma ação própria, a vida social se individualiza; e porque a contiguidade é criadora de comunhão, a política se territorializa, com o confronto entre organização e espontaneidade. O lugar é o quadro de uma referência pragmática ao mundo, do qual lhe vêm solicitações e ordens precisas de ações condicionadas, mas é também o teatro insubstituível das paixões humanas, responsáveis, através da ação comunicativa, pelas mais diversas manifestações da espontaneidade e da criatividade. (SANTOS, 2004, p. 218)
\end{abstract}

Os Kalunga organizam-se em fóruns formais de participação, como a Associação Quilombo Kalunga, e de modo informal, como a exemplo do mutirão da estrada, para buscar o acesso a políticas públicas a todos que estão dentro de seu território. Os Kalunga estão cientes que a privação de funcionamentos ${ }^{34}$ leva ao êxodo das novas gerações, que vão para as cidades em busca de uma qualidade de vida que eles não encontram no seu território.

\footnotetext{
${ }^{34} \mathrm{O}$ conceito de funcionamentos de Sen (2010) reflete as várias coisas que uma pessoa pode considerar valioso fazer, variando das mais elementares - como estar bem nutrido e saudável aos estados pessoais mais complexos - como poder participar da vida em sociedade e ter respeito próprio.
} 
Com mobilidade negada no Vão do Moleque e no Vão de Almas, os jovens Kalunga, ao terem que sair de seu lugar a fim de acessar o ensino médio, não mais retornam. Santos afirma que "a migração, em última instância, é, sem paradoxo, consequência também da imobilidade. Quem pode, como já mencionamos, vai consumir e volta ao lugar de origem. Quem não pode locomover-se periodicamente, vai e fica”. (SANTOS, 2104, p. 63).

Os Kalunga entrevistados também entendem que os jovens anseiam pelo acesso a tecnologias, como internet e bens de consumo, a saber: celulares e carros. Por isso, gostariam que seu território possibilitasse o consumo das novas técnicas disponíveis. Pois, "quem não pode mover-se periodicamente para obter os novos itens de consumo que a publicidade lhe insinua, acaba saindo de vez" (SANTOS, 2014, p. 62).

A emigração dos jovens preocupam os Kalunga, cientes de que a presença deles no território é fundamental para o espaço Kalunga. Santos (2014, p. 80) diz que "o espaço é igual a paisagem mais a vida nela existente, é a sociedade encaixada na paisagem, a vida que palpita conjuntamente com a materialidade". A paisagem é metamorfoseada no espaço na medida que os Kalunga persistem na disputa de poder pelo território, cuja titulação ainda não trouxe à grande parte dos povoados os benefícios esperados.

O apoderamento de seu território se dá pela vivência, pelo fato de as gerações anteriores terem vivido ali. Não há como tirar dos Kalunga a autonomia sobre o seu território, a não ser que eles deixem de existir tal como são. Espera-se, portanto, que o Estado brasileiro faça ser possível a perpetuação do espaço da comunidade remanescente de quilombo, fazendo valer seus direitos de propriedade e de uso da propriedade para a produção, seus direitos sociais e o consequente aumento de suas capacidades ${ }^{35}$.

Entretanto, se o Estado não acolhe os Kalunga no processo de desenvolvimento por meio da inserção de políticas públicas que aumentem as possibilidade de produção e circulação do capital, o acesso ao território por não quilombolas é facilitado, na medida em que a resistência deixa de fazer sentido com a saída dos jovens e o envelhecimento da população Kalunga.

\footnotetext{
${ }^{35}$ Sen (2010) emprega o conceito de capacidade como sendo a possibilidade de uma pessoa realizar combinações alternativas de funcionamentos. Capacidades são as liberdades substantivas que possibilitam que uma pessoa realize seus objetivos.
} 
O relato de Seu Zezinho, constante do capítulo 3, sobre o fato de a titulação tê-los prejudicado por não possibilitá-los capitalizar suas terras mostra que os intitulamentos ${ }^{36}$ econômicos dos Kalunga são escassos. A facilidade econômica é um das liberdades instrumentais consideradas por Sen (2010, p.59): "são oportunidades que os indivíduos têm para utilizar recursos econômicos com propósitos de consumo, produção ou troca". Com dinheiro em mãos, Seu Zezinho acredita que os Kalunga viveriam mais livremente, pois a facilidade econômica encadearia outras liberdades como oportunidades sociais. "O argumento de que a liberdade não é apenas o objetivo primordial do desenvolvimento, mas também seu principal meio, relaciona-se particularmente a esses encadeamentos" (SEN, 2010, p.58).

Seu Zezinho acredita que, com liberdade econômica, eles poderiam, independentemente do Estado, instalar sua própria energia e encanar a água das serras e levar para suas casas. Nota-se que o Estado não é visto por ele como provedor de bens e serviços a todos que têm direito. A visão da grande maioria dos entrevistados que creditaram o desenvolvimento do Engenho II à persistência de um líder e à organização de uma comunidade demonstra o descrédito deles em relação à capacidade do Estado de garantir direitos sociais a todos.

Santos destaca que "o espaço se dá ao conjunto dos homens que nele se exercem como um conjunto de virtualidades de valor desigual, cujo uso tem de ser disputado a cada instante, em função da força de cada qual” (2004, p. 215). Apesar da grande união entre os Kalunga, nem todos percebem ter a mesma força. Os relatos apontaram que as pessoas que participavam dos fóruns de participação social foram as mesmas durante anos. A impressão relatada é que esses líderes lutaram com persistência pelo desenvolvimento do território Kalunga como um todo, mas, talvez por terem feito uma gestão personalista, os lugares onde eles vivem são os mais beneficiados pelas políticas públicas.

Os dados da pesquisa do MDS e o resultado do trabalho de campo apontam a dialética da provisão de serviços públicos e infraestrutura nos lugares Kalunga. Enquanto, no Engenho II a população Kalunga foi beneficiada com energia elétrica, casas de alvenaria e telhas e banheiros, escola de ensino médio, posto de saúde e acesso à água; no Vão do Moleque e no Vão de Almas, onde se concentra a maior parte da população Kalunga, os Kalunga ainda

\footnotetext{
${ }^{36}$ Sen (2010) emprega o conceito de entitlement traduzido como intitulamento. Entitlement implica em direito a um conjunto de provisões de bens e serviços pelo governo
} 
vivem no escuro, sem qualquer possibilidade de ter eletrodomésticos como geladeira, carregando baldes de água, além de terem que viajar em caminhão pau-de-arara por uma estrada sem trafegabilidade, atravessando por dentro de córregos, para ir à cidade ter alguma assistência médica ou sacar seus benefícios sociais, como o Bolsa Família e a aposentadoria.

No entanto, mesmo no Engenho II, onde, nas palavras de seus moradores, "o desenvolvimento chegou", as condições de vida saudável e as oportunidades de produção dos Kalunga ainda dependem de uma gama de serviços públicos e programas governamentais não disponíveis. O transporte do Engenho II para Cavalcante, apesar de serem somente $37 \mathrm{~km} \mathrm{em}$ estrada de chão trafegável, não é diário e não é ofertado pelo município.

No entanto, a provisão de um mínimo de infraestrutura e serviços públicos, juntamente com o reconhecimento da comunidade como quilombola, fortaleceu o sentimento de coletividade. A comunidade do Engenho II organizou-se, com o apoio em especial do governo estadual, para o turismo, gerando autonomia para parte da população que consegue gerar renda por meio da atividade de guia turístico, da venda de refeições e de produtos agrícolas e artesanais, entre outras possibilidades criadas.

Santos (2006, p. 81) diz que "ações não se localizam de forma cega", e nem os homens, nem as instituições e nem as infraestruturas. Assim, os lugares se desenvolvem de forma desigual e combinada:

O desenvolvimento desigual e combinado é, pois, uma ordem, cuja inteligência é apenas possível mediante o processo de totalização, isto é, o processo de transformação de uma totalidade em outra totalidade.

Foi relatado pelos entrevistados que o isolamento geográfico do Vão de Almas e do Vão do Moleque pode ser um dos fatores explicativos para a ausência de muitos programas governamentais sociais, mas isso não isenta o Estado de prover seus direitos sociais com qualidade e quantidade. Os Kalunga têm conhecimento disso ao demonstrar sua insatisfação geral com os gestores municipais: "diz que o dinheiro do governo federal vem. Mas esse dinheiro que vem de fora, se passar pela prefeitura, ninguém vê ele, num chega (Seu Albertino, março de 2015)."

Se a escala federativa propõe uma ação mais pontual por parte dos municípios brasileiros, que deveriam dar encaminhamento às demandas sociais da população local rural 
ou urbana, a fim de dar funcionalidade ao aparato administrativo necessário para encaminhar as políticas públicas, o distanciamento geográfico não deve ser justificativa para o isolamento ou o descaso do poder público.

O Governo Federal lançou duas grandes frentes de atuação com o objetivo de reduzir a pobreza e aumentar as oportunidades de acesso a políticas públicas de desenvolvimento e serviços públicos essenciais a populações mais vulneráveis, o Programa Brasil Sem Miséria BSM e o Programa Brasil Quilombola - PBQ, descritos no capítulo 2. No entanto, para alcançar os territórios mais pobres, em especial territórios de povos e comunidades tradicionais, como é o caso dos quilombolas, o Governo Federal depende da ação do Governo Local. No entanto, cada escala federativa possui um nível de intencionalidade na política pública.

Segundo Santos (2006), a intencionalidade da ação está relacionada aos objetos, e ambas dependem da carga de ciência e técnica presente em determinado território onde se aplica a ação humana. Porém ele destaca que os resultados da ação não dependem somente da decisão racional e de sua execução. Há certa imponderabilidade no resultado devido à natureza e ao caráter humano. Assim, quem está na gestão faz a grande diferença. Os atores políticos são a minoria planejadora a quem interessa a localização das infraestruturas. A quem esses atores estão ligados politicamente e financeiramente é outro fator relacionado ao caráter humano da política pública.

Portanto, a articulação do poder público federal com o local deve levar em conta a provisão de objetos geográficos necessários para a implementação da política pública localmente conjugada com a intencionalidade de ação do poder local.

Um dos principais eixos do BSM e no PBQ para geração de capacidade e autonomia da população pobre rural são os programas de inclusão produtiva rural. Porém, estes não alcançaram o território Kalunga. Grande parte dos entrevistados não têm nem conhecimento sobre programas como o Fomento, a Assistência Técnica a Atividades Produtivas Rurais Ater, o Programa de Aquisição de Alimentos -PAA e o Programa Cisternas para captação de água para produção e para consumo. Os que possuíam algum conhecimento sobre os programas não tinham informação sobre o seu funcionamento ou sobre a forma de acessá-los. 
A efetiva implantação do Programa de Aquisição de Alimentos, por exemplo, principal ação no eixo de inclusão produtiva rural do BSM e do PBQ, no território Kalunga implica que outras políticas estruturantes sejam implantadas em conjunto, como a construção de pontes e estradas transitáveis, a provisão de cisternas, a instalação de energia, além de tal implantação depender significantemente da intenção da prefeitura de adquirir a produção dos Kalunga para provisão de alimentos nas escolas, hospitais e outros equipamentos públicos existentes .

Portanto, a produção no Vão de Almas e no Vão do Moleque esbarra na ausência de objetos que insiram seus produtos no circuito sistêmico da produção, seja a produção agropecuária ou exploração turística do território. Os Kalunga creditam a falta de estruturas que os possibilitem entrar no mercado de produção ao descaso por parte do município.

No Engenho II, por outro lado, a modernização do espaço retrata a inserção efetiva de políticas públicas de infraestrutura e provisão de bens e serviços públicos. A autonomia de seus moradores é demonstrada nos relatos de maior participação da vida em comunidade, de maior sentimento de autoestima, e de consumo de comodidades, hoje quase universais no Brasil, entretanto recentes no Engenho II, como televisores, geladeiras, automóveis e tanquinho ou máquina de lavar roupa.

Já o isolamento funcional e geográfico das comunidades do Vão do Moleque e do Vão de Almas perante a ausência de infraestrutura e a dificuldade de acesso aos bens de consumo tem consequências na organização das relações sociais e econômicas dos Kalunga, assim como no modo como estruturam a vida cotidiana de suas famílias.

O cotidiano das mulheres que passam grande parte do dia indo aos rios para lavar roupas e louças e buscar água no balde afetam substancialmente sua qualidade de vida e saúde, muitas vezes incapacitando-as para o trabalho, devido a cervicalgias e problemas de coluna. As crianças que andam horas, em alguns casos tendo que atravessar rios e córregos, faça chuva ou faça sol, para ir e voltar da escola provavelmente encontram-se menos motivadas para aprender e completar o ciclo de ensino fundamental e médio.

Com a ausência de escolas de ensino médio em grande parte da comunidade Kalunga, à exceção do Engenho II, as opções disponíveis para os jovens Kalunga não são as desejáveis para um país que pretende acabar com o clico geracional da pobreza: não continuam os 
estudos após o $9^{\circ}$ ano, ou mudam-se para a cidade para trabalhar e estudar, ou, nos melhores casos, quando os pais possuem uma casa na cidade, mudam-se para cidade para estudar e ficam sob cuidados de avós idosos ou de irmãos mais velhos.

A organização familiar para realizar compras na cidade, que em geral se resumem a material escolar, roupas e sapatos, alimentos e milho e sal para os animais, se dá basicamente nos dias de recebimento do Bolsa Família ou da aposentadoria. Devido ao alto valor pago no transporte, privado, os Kalunga priorizam o dia de pagamento dos benefícios também para realizar consultas médicas e vender sua produção agrícola - como a abóbora e o milho ou produtos manufaturados - com a farinha.

A renda regular de grande parte das famílias entrevistadas oriunda do Programa Bolsa Família e da aposentadoria rural. A garantia de uma renda mensal permite que eles se organizem financeiramente para a compra de algum bem ou para a benfeitorias em suas casas e terras, principalmente nos domicílios onde há aposentados, cujo renda é maior.

Ao Bolsa Família também foi creditada a superação da fome, que já castigou muito o povo Kalunga em épocas de seca. Todos os entrevistados relataram ter disponibilidade de comida durante todo o ano em suas casas por causa do pouco dinheiro passado diretamente às famílias pelo Programa. Os Kalunga, que relataram já ter trabalhado o dia inteiro por um prato de comida, hoje sentem que eles podem recusar um trabalho análogo a trabalho escravo, pois possuem o mínimo para comprar alimentação.

A expansão de liberdade em virtude do Bolsa Família é maior ainda entre as mulheres, que, segundo relatos, sempre tiveram maior dificuldade para ter dinheiro em mãos. Hoje, com o Bolsa Família sentem-se mais autónomas inclusive para sair de uma situação de casamento infeliz, pois sentem que tem o mínimo para sobreviver.

Coincidentemente, foram as duas mulheres com quem conversei no Engenho II que me disseram que, comparado ao que já passaram, se consideram ricas. A riqueza relatada por elas é entendida como aumento de suas liberdades para alcançarem os seus fins. A provisão de uma renda mínima pelo Estado, juntamente com a provisão de serviços públicos de saúde, de ensino fundamental e médio para seus filhos dentro de sua própria comunidade, de moradia com um mínimo de conforto como chão e paredes de cimento, de infraestrutura que 
implica diretamente na qualidade de vida delas como a energia elétrica e a água encanada, fazem as mulheres do Engenho II sentirem-se capazes de levar a vida que querem levar.

Consequentemente, o aumento das capacidades das mulheres do Engenho II trouxe a elas a autonomia para serem mais produtivas e, como resultado auferir renda mais elevada, para participar da vida da comunidade. Somente no Engenho II, as mulheres têm uma associação própria vinculada a sua atividade produtiva de artesãs. No Engenho, muitas delas também trabalham como guias turísticas, participando ativamente de associação de guias, e na provisão de serviços aos turistas, como refeições nos restaurantes e bares e hospedagem nas pousadas.

Apesar de o conceito de pobreza adotado pelo Governo Brasileiro para a formação do BSM e do PBQ estar atrelado à renda, em certa medida, essas políticas incluem entre seus objetivos outras dimensões da pobreza. Sem desconsiderar que a privação de renda constitua obstáculo para o aumento das capacidades e liberdades das pessoas, outras dimensões da pobreza foram consideradas: precário acesso a serviços públicos de saúde e educação, ausência de capacidades de gerar renda, ausência de infraestruturas básicas de qualidade de vida e de vida saudável como moradia, esgoto, saneamento, energia e água e escassa participação social.

As políticas e programas integrados nas duas estratégias de erradicação da pobreza extrema e de melhoria de qualidade de vida da população quilombola pretendem proporcionar autonomia e capacidades a fim de quebrar o ciclo de pobreza geracional entre os remanescentes de quilombo. Os resultados esperados incluem capacidades desenvolvidas, acessibilidades a oportunidades relacionadas aos valores quilombolas, e seu sentido de liberdade.

Conforme as demandas apresentadas pelos remanescentes de quilombo do Brasil ao Governo Brasileiro no Encontro Nacional de Povos e Comunidades Tradicionais, listadas no Capítulo 2, aos quilombolas interessa estar dentro da agenda de desenvolvimento do país. Demandas relacionadas ao aumento do nível de escolaridade, ao fortalecimentos dos órgãos essenciais à titulação de seus territórios, como a Fundação Cultural Palmares e o INCRA, ao acesso à infraestrutura e aos serviços de saúde, bem como na promoção de desenvolvimento de capacidades para geração de renda e gestão de seu território permeiam todas as 
comunidades, inclusive a Kalunga, objeto deste estudo.

No entanto, o atendimento das demandas quilombolas pelo Governo Federal esbarra na questão federativa e nas disputas de poder pelo território. Em nível local, interesses políticos entram em choque com a expectativa da população quilombola de finalmente ter sua liberdade para gerir seu território e autonomia para gerar renda.

A comunidade Kalunga, ao apresentar desenvolvimento desigual dentro de seu próprio território, permitiu a comparabilidade entre lugares que tiveram acesso a políticas de infraestrutura e programas sociais e lugares ainda carentes de acesso ao Estado brasileiro.

Os Kalunga do Engenho II e os Kalunga do Vão de Almas e Vão do Moleque possuem diferentes níveis de independência e capacidades. No Engenho II, onde políticas públicas de saúde e educação, energia, mobilidade e água, telefonia e geração de renda foram implementadas, os Kalunga sentem-se inseridos no processo de desenvolvimento por sentirem-se livres para alcançar seus fins, por sentirem ter capacidades de participar de fóruns sociais e organizar suas demandas e prioridades. Nos lugares onde a política pública teve alcance, como o Engenho II, o sentimento de pertencimento a um Estado que garante os direitos de seus cidadãos favorece a autoestima e a identidade quilombola.

Já os Kalunga do Vão de Almas e Vão do Moleque, por seu território carecer de políticas públicas que abordem as diversas dimensões da pobreza que privam a sua liberdade, sentem-se esquecidos e abandonados pelo Estado brasileiro, tendo perdido a esperança de que o Estado irá lhes prover serviços e bens público que melhore a sua qualidade de vida: "O povo lá de fora gosta de empurrar a gente com a barriga" (Seu Albertino, março de 2015). Os direitos sociais, estabelecidos no art. $6^{\circ}$ da Constituição Federal, como educação, saúde, alimentação, trabalho, moradia, lazer e assistência do Estado são compreendidos pelos Kalunga, porém o seu alcance, que deve se dar por meio de políticas públicas e programas sejam eles federais, estaduais ou municipais, ainda não é uma realidade para a maior parte da população Kalunga, localizada no Vão de Almas e no Vão do Moleque. E, conforme dito antes, os Kalunga já esperaram demais.

Santos afirma que "cada lugar é teatro de tempos 'externos' múltiplos” (2006, p. 90). O tempo lento do lugar Kalunga não serve mais àquela população do Vão de Almas e do Vão 
do Moleque, que, testemunhando o desenvolvimento "de fora", tem sonhos, quer ver seus jovens voltarem ao seu território, resiste e luta para que se possibilite ter a liberdade de se “viver a vida que eles têm razão para valorizar" (SEN, 2010). 


\section{REFERÊNCIAS BIBLIOGRÁFICAS E ELETRÔNICAS}

AGUILAR VILLANUEVA, Luis. F. Estudio introductorio. In:

(Org.) La

Implementación de las políticas. 2. ed. México: Miguel Ángel Porrua, libero-editor, 1993.p. 15-91. (Colección Antologias de Política Pública - terceira antologia).

AGUILAR VILLANUEVA, Luis. F. Estudio introductorio. In: La hechura de las políticas. México: Porrúa, 1992, p. 15-40.

ALMEIDA, Maria Geralda. TERRITORIOS DE QUILOMBOLAS: pelos vãos e serras dos Kalunga de Goiás - patrimônio e biodiversidade de sujeitos do Cerrado. Ateliê GeográficoED. ESPECIAL Goiânia-GO v. 4 n. 1 fev/2010 p.36-63. Instituto de Estudos SócioAmbientais-IESA - Universidade Federal de Goiás-Brasil.

ANJOS, Rafael Sânzio Araújo dos. O espaço geográfico dos remanescentes de quilombos no Brasil. Terra Livre. 17n. São Paulo: UNN, 2001.

ARANTES, L; MARTINS, F.; FLIT, R. Programa Brasil Quilombola: avanços e desafios. IN: Caderno de Estudos Desenvolvimento Social em Debate. -N. 20: Quilombos do Brasil: Segurança Alimentar e Nutricional em Territórios Titulados, novembro: 171-196. 2014.

ARRETCHE, Marta. Federalismo e Políticas Sociais no Brasil: problemas de coordenação e autonomia. IN: São Paulo em Perspectiva, 18(2): 17-26, 2004.

ARRUTI, JOSÉ M. Políticas Públicas Para Quilombos: Terra, Saúde e Educação. In: Caminhos convergentes: Estado e Sociedade na superação das desigualdades raciais no Brasil. Orgs. Paula, Marilene de e HERINGER, Rosana. Rio de Janeiro, Fundação Heinrich Boll / ActionAid. 2009

BACELAR, Tânia. Palestra Magna: política pública, participação, desenvolvimento sustentável e territórios. IN: MIRANDA, Carlos; TIBÚRCIO, Breno (org); BACELAR, Tânia... [et.al] (autores). Articulação de políticas públicas e atores sociais. -Brasília: IICA, 2008.

BAIOCCHI, M. de N. Kalunga: povo da terra. Goiânia: UFG, 2006.

BAUMAN, Zygmund. Identidade. Rio de Janeiro: Zahar, 2005.

BEAUD, Stéphane; WEBER, Florence. Guia para a pesquisa de campo: Produzir e analisar dados etnográficos. Petrópolis: Vozes, 2007.

BONETI, L. W. Políticas públicas por dentro. Ijuí (RS): Unijuí, 2007.

BRANDÃO, André Augusto, DALT, Salete e Gouveia, Victor. Relatório de Pesquisa:

Avaliação Diagnostica do Acesso das Comunidades Quilombolas aos Programas do MDS.

Niterói, DataUFF - UFF, 2008 b. 
BRASIL. Secretaria Geral da Presidência.

http://www.secretariageral.gov.br/art_social/conselhos-e-conferencias Acesso em 30 mar 2014.

BRASIL. Senado. Constituição da República Federativa do Brasil. - Brasília, Distrito Federal, 1988.

BRASIL. Ministério da Cultura. http://www.palmares.gov.br/quilombola/\# . Acesso em 16 de jun. 2013.

BRASIL. Ministério do Desenvolvimento Social e Combate à Fome. http://aplicacoes.mds.gov.br/sagi/FerramentasSAGI_menu/internet.php . Acesso em 02 jul 2013.

BRASIL. Secretaria Especial de Promoção de Políticas para Igualdade Racial. http://monitoramento.seppir.gov.br/paineis/pbq/index.vm?eixo=1. Acesso em 9 de abril de 2015.

BRASIL. Ministério do Planejamento, Orçamento e Gestão. Plano Mais Brasil PPA 20122015: agendas transversais- monitoramento participativo: ano base 2012- Brasília, DF: MP/SPI, 2013.

BRASIL. Ministério do Planejamento, Orçamento e Gestão. Plano Mais Brasil PPA 20122015: Relatório Anual de Avaliação: ano base 2012 / - Brasília : MP/SPI, 2013. Disponível em:

http://www.planejamento.gov.br/secretarias/upload/Arquivos/spi/publicacoes/130612_Rel_A val_2013_Vol_1.pdf

BRASIL. Presidência da República. Programa Brasil Quilombola Diagnóstico de Ações Realizadas. Julho, 2012. Disponível em http://www.seppir.gov.br/destaques/diagnostico-pbqagosto. Acesso em 18 de abril de 2015.

BRASIL. Presidência da República. Relatório de Gestão do Programa Brasil Quilombola. Abril, 2013. Disponível em: http://www.seppir.gov.br/.arquivos/relatorio-pbq-2012 . Acesso em 16 jun. 2013.

BRASIL. Ministério do Desenvolvimento Social e Combate à Fome, Secretaria de Avaliação e Gestão da Informação. Caderno de Estudos Desenvolvimento Social em Debate. -N. 20: Quilombos do Brasil: Segurança Alimentar e Nutricional em Territórios Titulados, novembro, 2014.

BRASIL. Ministério do Desenvolvimento Social e Combate à Fome, Secretaria de Avaliação e Gestão da Informação. Pesquisa de Avaliação da Situação de Segurança Alimentar e Nutricional em Comunidades Quilombolas Tituladas. Contrato no 10-12484 (Projeto BRA/04/046/PNUD). Relatório final: Produto 5. Niterói/RJ: DataUFF/FEC, dezembro, 2012.

BRASIL. Ministério da Educação. Uma história do povo Kalunga. / Secretaria de 
Educação Fundamental, 2001.

BRUGUÉ, Q. Transversalidad: del concepto a la práctica, de las ideas a los resultados. Institut de Govern i Polítiques Públiques (IGOP - UAB). Seminário de Gestão Pública. Da eficiência à inteligência: a administração pública deliberativa para a construção de inteligência coletiva na gestão. Escola Nacional de Administração Pública - Enap, 20 a 21 de junho de 2012.

BRYNARD, P. Policy Implementation, in Cloete and Wissink. (eds.) Improving public policy. - Pretoria. Van Schaik. 2000.

CABRAL, João de Pina. Semelhança e verossimilhança: horizontes da narrativa etnográfica. Mana 9(1): 109-122, 2003.

CAMPOS et al. Inclusão Produtiva Rural no Plano Brasil Sem Miséria: Síntese da Experiência Recente em Políticas Públicas para o Atendimento dos Mais Pobres no Rural Brasileiro. IN: O Brasil Sem Miséria. Org. CAMPELLO, Tereza; FALCÃO, Tiago; COSTA, Patricia V. -Brasília: MDS, 2014.

CASTRO, Iná Elias. Solidariedade Territorial e Representação. Novas Questões para o Pacto Federativo Nacional. IN: Revista TERRITÓRIO, 1(2): 33-42, 1997.

CABRAL, M.A.E. O Potencial turístico de Cavalcante no âmbito da Região da Chapada dos Veadeiros. In: Steinberger, Marília (org.). Territórios Turísticos no Brasil Central/ Marília Steinberger et alii- Brasília: LGE Editora, 2009.

CARLOS, Ana Fani A. A Cidade. São Paulo: Contexto, 1992.

CLAVAL, Paul. A Geografia cultural, 2 ed. Florianópolis: UFSC, 1999.

FLEURY, S.; OUVERNEY, A. L. M. Gestão de redes: a estratégia de regionalização da política de saúde. Rio de Janeiro: Editora FGV: Cap. 1, 2007.

FRANCO, Rangel Donizete. A desapropriação e a regularização dos territórios quilombolas [manuscrito]. Dissertação de Mestrado. Programa de Mestrado em Direito Agrário da Universidade Federal de Goiás, 2012. xv, 195 f.

FROZI, Daniela Sanches. Multidimensionalidade da pobreza em comunidades quilombolas: aspectos analíticos para a segurança alimentar e nutricional. IN: Caderno de Estudos Desenvolvimento Social em Debate. -N. 20: Quilombos do Brasil: Segurança Alimentar e Nutricional em Territórios Titulados: 69-91, 2014.

GEERTZ, Clifford, 1926. A interpretação das culturas - 1.ed., IS.reimpr. - Rio de Janeiro : LTC, 2008.

GONTIJO, José G. L. “Coordenação, cooperação e políticas públicas: organizando percepções e conceitos sobre um tema caro à implementação". In: FARIA, Carlos A. 
Implementação de políticas públicas: teoria e prática. Belo Horizonte: Ed. PUC Minas: 82$122,2012$.

GUARESCHI, N. Problematizando as práticas psicológicas no modo de entender a violência. In: STREY, Marlene (Org.). Violência, gênero e políticas públicas. Porto Alegre: EDIPUCRS, 2004.

HAESBAERT, Rogério. Da desterritorialização à multiterritorialidade. Anais do $\mathrm{X}$ Encontro de Geógrafos da América Latina- Universidade de São Paulo- 20 a 26 de março de 2005.

IBGE. Pesquisa Nacional Por Amostra de Domicílios: PNAD 2011. IBGE, Rio de Janeiro, $2012 . \quad$ Disponível em http://www.ibge.gov.br/home/presidencia/noticias/imprensa/ppts/00000010135709212012572 220530659.pdf

IBGE. Síntese de Indicadores Sociais - 2012. IBGE, Rio de Janeiro, 2012.

JACCOUD, Luciana. O Combate ao Racismo e à Desigualdade: o desafio das políticas públicas de promoção da igualdade racial. IN: As Políticas Públicas e a Desigualdade Racial no Brasil: 120 anos após a abolição. Org. THEODORO, Mario; JACCOUD, Luciana; OSÓRIO, Rafael; SOARES, Sergei. -Brasília: IPEA, 2008, p. 131- 166.

JANNUZZI, Paulo de Martino. Indicadores Sociais no Brasil. 4 ed. -Campinas, SP: Editora Alínea, 2009.

MARGALIT, Avishai. The Decent Society - Cambridge (MA): Harvard University Press, 1996.

MOREIRA, Ruy. Geografia e Práxis: a presença do espaço na teoria e prática geográficas. São Paulo: Contexto, 2012.

OLIVEIRA, Bernadete Castro. Tempo de travessia, tempo de recriação: os camponeses na caminhada. In: Estudos Avançados 15 (43), 2001.

Espaço como substrato para constituição da subjetividade. Seminário

Nacional: a questão da terra, desafios para a psicologia. Brasília, 20, 21 e 22 de julho de 2006. Disponível em http://www.crprj.org.br/publicacoes/relatorios/seminario-terra.pdf Acesso em 30 mar 2014.

OSÓRIO, Rafael G.; SOARES, Sergei, S.D. O Brasil Sem Miséria e as Mudanças no Desenho do Bolsa Família. IN: O Brasil Sem Miséria. Org. CAMPELLO, Tereza; FALCÃO, Tiago; COSTA, Patricia V. -Brasília: MDS, 2014.

PAIVA, Luis H.; FALCÃO, Tiago; BARTHOLO, Letícia. Do Bolsa Família ao Brasil Sem Miséria: Um resumo do percurso brasileiro recente na busca da superação da pobreza extrema. IN: Programa Bolsa Família: Uma década de inclusão e cidadania. Org.

CAMPELLO, Teresa e NERI, Marcelo Côrtes. -Brasília: IPEA-2013 
PNUD. Atlas de Desenvolvimento Humano 2013. Disponível em: http://www.atlasbrasil.org.br/2013/ . Acesso em: 23 de fevereiro de 2014.

SANTINHA, G. e MARQUES, T. A integração do princípio de Coesão Territorial na agenda política: o caso português. Revista de Geografia e Ordenamento do Território, $\mathrm{n}^{\circ} 2$ (Dezembro). Centro de Estudos de Geografia e Ordenamento do Território. Pág. 215 a 244, 2012.

SANTOS, M.; SILVEIRA, M.L. O Brasil: Território e sociedade no início do século XXI. Rio de Janeiro: Record, 2001.

SANTOS, Milton. A Natureza do Espaço. 4. ed. São Paulo: EDUSP, 2006.

Por uma Geografia Nova: Da Crítica da Geografia a uma Geografia Crítica. -6. ed., 1. Reimp.- São Paulo: Editora da Universidade de São Paulo, 2008.

de São Paulo, 2012a.

Espaço e Método. 5. ed., 1. Reimp. -São Paulo: Editora da Universidade

Metamorfoses do Espaço Habitado. 6. ed. 2. Reimpr. -São Paulo: Editora da Universidade de São Paulo, 2014.

Pensando o Espaço do Homem. 5 ed. 3. Reimpr. - São Paulo: Editora da Universidade de São Paulo, 2012.

Sandra Lencioni (trad.). O Trabalho do Geógrafo no Terceiro Mundo. 5 ed.- Editora da Universidade de São Paulo, 2009.

Por uma outra globalização: do pensamento único à consciência universal. -22a ed.- Rio de Janeiro: Record, 2012b.

SARAVIA, Enrique. Política Pública: dos clássicos às modernas abordagens. IN: Políticas Pública:coletânea. Org. Enrique Saravia e Elizabete Ferrarezi. - Brasília: ENAP, 2006

REGO, Walquiria Leão. PINZANI, Alessandro. Vozes do Bolsa Família: autonomia, dinheiro, e cidadania. São Paulo: Editora Unesp, 2013.

SCHWARTZ, Bernard. American Constitutional Law. London: Cambridge University Press, 1955.

SEN, Amartya. Desenvolvimento como liberdade. São Paulo: Companhia das Letras, 2010.

SERRANO, Agnes de França. A implementação do Centro Metropolitano de BrasíliaDistrito Federal e as transformações do espaço intraurbano. 2014. 168 p. (Dissertação de Mestrado em Produção do Espaço e Território Nacional. Instituto de Ciências Humanas. Departamento de Geografia. UNB). 
SILVA, Martiniano José. Quilombos do Brasil Central: Violência e Resistência Escrava. Goiânia: Kelps, 2008.

SOJA, Edward. Espacializações: a geografia marxista e a teoria social crítica. In: Geografias Pós-Modernas. Rio de Janeiro: Ed. Jorge Zahar, 1993, pp.57 - 116.

SOUZA, Celina. Políticas Públicas: uma revisão da literatura. In: Sociologias, Porto Alegre, ano 8, no 16, jul/dez 2006, p. 20-45.

SPOSITO, Eliseu Savério. Geografia e filosofia: contribuição para o ensaio do pensamento geográfico. - São Paulo: Editora UNESP, 2004.

THEODORO, Mario. A Formação do Mercado de Trabalho e a Questão Racial no Brasil. IN: As Políticas Públicas e a Desigualdade Racial no Brasil: 120 anos após a abolição. Org. THEODORO, Mario; JACCOUD, Luciana; OSÓRIO, Rafael; SOARES, Sergei. -Brasília: IPEA, 2008, p. 15-43.

THEODORO, Mario. À Guisa da Conclusão: o difícil debate da questão racial e das políticas públicas de combate à desigualdade e à discriminação racial no Brasil. IN: As Políticas Públicas e a Desigualdade Racial no Brasil: 120 anos após a abolição. Org. THEODORO, Mario; JACCOUD, Luciana; OSÓRIO, Rafael; SOARES, Sergei. -Brasília: IPEA, 2008, p.167-176.

TUMELERO, Silvana Marta. Intersetorialidade na gestão de políticas públicas. Seminário Nacional Sociologia \& Política. Universidade Federal do Paraná - UFPR, 26 a 28 de setembro de 2011.

VELlOSO, A.D. Mapeando Narrativas: Uma análise do processo histórico-espacial da comunidade do engenho II- Kalunga. 2007. 162 p. Dissertação (Mestrado em Gestão ambiental e Territorial)- Departamento de Geografia/ Instituto de Ciências Humanas, Universidade de Brasília, Brasília.

UNGARELLI, Daniella Buchmann. A Comunidade Quilombola Kalunga do Engenho II: Cultura, produção de alimentos e ecologia de saberes. Dissertação de Mestrado. Centro de Desenvolvimento Sustentável, Universidade de Brasília, Brasília. Brasília, 2009. 83 p. :Il.

Legislação:

ACÓRDÃO N² 2771/2014 - TCU - Plenário, publicado no Diário Oficial da União em 05 de novembro de 2014.

DECRETO N 4.887, DE 20 DE NOVEMBRO DE 2003. Presidência da República.

Regulamenta o procedimento para identificação, reconhecimento, delimitação, demarcação e titulação das terras ocupadas por remanescentes das comunidades dos quilombos de que trata o art. 68 do Ato das Disposições Constitucionais Transitórias.

DECRETO DE 13 DE JULHO DE 2006. Presidência da República. Altera a denominação, competência e composição da comissão nacional de desenvolvimento sustentável das 
comunidades tradicionais e dá outras providências, criada pelo Decreto de 27 de dezembro de 2004..

DECRETO No 3.912, DE 10 DE SETEMBRO DE 2001. Presidência da República. Regulamenta as disposições relativas ao processo administrativo para identificação dos remanescentes das comunidades dos quilombos e para o reconhecimento, a delimitação, a demarcação, a titulação e o registro imobiliário das terras por eles ocupadas. Revogado pelo Decreto $\mathrm{n}^{\mathrm{o}}$ 4.887, de 20.11.2003

DECRETO Nº 6.040, DE 7 DE FEVEREIRO DE 2007. Presidência da República. Institui a Política Nacional de Desenvolvimento Sustentável dos Povos e Comunidades Tradicionais.

DECRETO DE 20 DE NOVEMBRO DE 2009. Presidência da República. Declara de interesse social, para fins de desapropriação, os imóveis abrangidos pelo "Território Quilombola Kalunga", situado nos Municípios de Cavalcante, Teresina de Goiás e Monte Alegre de Goiás, Estado de Goiás

INSTRUÇÃO NORMATIVA N 20, DE 19 DE SETEMBRO DE 2005, Instituto Nacional de Colonização e Reforma Agrária, Ministério do Desenvolvimento Agrário. Regulamenta o procedimento para identificação, reconhecimento, delimitação, demarcação, desintrusão, titulação e registro das terras ocupadas por remanescentes das comunidades dos quilombos de que tratam o Art. 68 do Ato das Disposições Constitucionais Transitórias da Constituição Federal de 1988 e o Decreto nº 4.887, de 20 de novembro de 2003

INSTRUÇÃO NORMATIVA Nº 57, DE 20 DE OUTUBRO DE 2009, Instituto Nacional de Colonização e Reforma Agrária, Ministério do Desenvolvimento Agrário. Regulamenta o procedimento para identificação, reconhecimento, delimitação, demarcação, desintrusão, titulação e registro das terras ocupadas por remanescentes das comunidades dos quilombos de que tratam o Art. 68 do Ato das Disposições Constitucionais Transitórias da Constituição Federal de 1988 e o Decreto ${ }^{\circ} 4.887$, de 20 de novembro de 2003.

LEI N ${ }^{0}$ 10.639, DE 9 DE JANEIRO DE 2003. Presidência da República. Altera a Lei no 9.394, de 20 de dezembro de 1996, que estabelece as diretrizes e bases da educação nacional, para incluir no currículo oficial da Rede de Ensino a obrigatoriedade da temática "História e Cultura Afro-Brasileira", e dá outras providências.

LEI N 11.346, DE 15 DE SETEMBRO DE 2006.Presidência da República. Cria o Sistema Nacional de Segurança Alimentar e Nutricional - SISAN com vistas em assegurar o direito humano à alimentação adequada e dá outras providências. 


\title{
ANEXO
}

\section{Diário de Campo - Comunidade Kalunga}

\author{
ENGENHO II, DIA 10 DE FEVEREIRO DE 2015
}

\section{ENGENHO II, CONVERSA COM SEU CIRILO DOS SANTOS ROSA}

A vida nos surpreende lindamente quando estamos no caminho certo.

Indo na estrada entre Cavalcante e o Engenho, achei que teria que usar o $4 x 4$, mas nem foi necessário, pois, apesar de ter chovido a noite inteira, a estrada estava patrolada, fácil de andar. Apesar de maravilhada com a exuberante paisagem das serras e do cerrado, eu ia apreensiva pois não tinha certeza se eu iria encontrar o Seu Cirilo, liderança quilombola Kalunga, pois eu não tinha conseguido falar com ele com antecedência. Se ele não estivesse lá, meu trabalho de campo estaria comprometido de início. Quando viro para onde a placa indicava "Engenho", vejo um homem negro de chapéu e penso "Deve ser Kalunga e deve estar indo para lá. Vou dar carona para ele. Quem sabe ele me apresenta para o Seu Cirilo”. Paro o carro e pergunto "quer carona?", e ele sorri e responde "sim". Entra no carro e diz “ prazer, sou Cirilo". "É de você mesmo que eu estou indo atrás". "Encontrou”.

A conversa começou bem, pois ele estava bem humorado e feliz de ter tido uma carona. Ele vestia uma camiseta do Encontro de Povos de Comunidades Tradicionais, que me deixou feliz, pois já me mostrou seu envolvimento e participação política. Mostrei a ele minha bolsa do Encontro Nacional de Povos e Comunidades Tradicionais e disse que tinha estado no último realizado em Brasília. Ele também tinha ido. A empatia mútua se formou.

Expliquei a ele meu projeto de pesquisa. Ele pareceu entender bem, pois tem estado envolvido com as políticas públicas há muito tempo e disse "é muito importante isso".

Me levou para o restaurante que eles tinham construído para receber os turistas que visitam as cachoeiras dentro do Sítio Histórico. Todo orgulhoso do lugar, e com razão, pois é um restaurante tipo varandona, agradável para qualquer turista que gosta de natureza. Falou um 
pouco sobre a importância do restaurante para bem receber os turistas, do Centro de Atendimento aos Turistas e da loja de produtos sustentáveis Kalunga, ambos frutos de um projeto em parceria com a Petrobrás. Falou de seu sonho de fazer um pousada para receber os turistas.

Perguntei a ele se os outros povoados dentro do Sítio Histórico Kalunga estão tão organizadas quanto o Engenho e ele, com muita certeza e certo ar de tristeza, disse que não, que no Território Kalunga, o povoado do Engenho foi o que mais se beneficiou do desenvolvimento. Este foi o gancho para minha pesquisa: Então o que melhorou para os Kalunga do Engenho? Por que eles desenvolveram mais que outros agrupamentos quilombolas Kalunga dentro do mesmo território?

Seu Cirilo fala primeiro da importância da união dos integrantes da comunidade e da fé que eles tem em Deus. Falou da demarcação das terras do Território Kalunga pela Fundação Cultural Palmares, que primeiramente tinha deixado o povoado Engenho e uma parte do Vão de Almas de fora do sítio. Então Seu Cirilo, consciente da importância de sua participação política, foi até a Presidente da Palmares à época, Maria Dulce Pereira, que o recebeu e o ouviu. Ele e alguns companheiros do Engenho falaram de sua história com o território e da vinda de seus ancestrais, o que convenceu a Presidente da FCP a pedir que os técnicos voltassem para demarcar o território incluindo o Engenho e o Vão de Almas, tal qual ele hoje se configura.

Este foi um grande marco na luta dos Kalunga : "Depois disso aí é só a gente se desenvolvendo". O reconhecimento de seu território representa o reconhecimento de sua história de vida, de sua identidade de luta e de pertencimento àquele lugar. "Melhorou nossa autoestima". Eles passaram a ter representatividade junto aos governos e a serem vistos como sujeitos de direitos. Ele fala com emoção que antes sofriam muito preconceito na cidade e que hoje eles são "tratados de outro jeito". Ele não foi muito específico sobre este "outro jeito", mas pelo menos ele não sente que seja preconceito.

Os Kalunga expressam sua participação social por meio de associações. A Associação Quilombo Kalunga é a associação mãe, que coordena as associações Kalunga de cada município- Monte Alegre, Cavalcante e Teresina, a associação de guias e a associação comunitária. 
Outro marco na luta pelo desenvolvimento de seu território foi uma reunião no SEBRAE GO, em que estiveram ele e duas outras lideranças dentro do Território, uma do município de Teresina e outro de Monte Alegre. O SEBRAE tinha a intensão de organizar o turismo e seus técnicos os consultaram quanto à possibilidade de abrir as cachoeiras do território para o turismo. Ele e a representante de Teresina concordaram já que entenderam naquele momento que o turismo poderia representar desenvolvimento para a Comunidade. O representante das comunidades de Monte Alegre, por medo de que isso representasse a ida de pessoas de má fé, que pudessem querer tomar suas terras, decidiu não abrir suas cachoeiras e rios.

Seu Cirilo não se arrependeu. Acredita que foi um acerto, pois o turismo tem sido um grande vetor de desenvolvimento ao trazer renda para a comunidade Engenho II.

O marco central então foi a visita do Presidente Lula à comunidade em março de 2004, quando do lançamento do Programa Brasil Quilombola. "Aí o desenvolvimento chegou”. Junto com o Presidente chegou a energia elétrica e vários programas de desenvolvimento humano foram implementados em seguida.

Seu Cirilo falou com muito gosto do fato de que as crianças e jovens da comunidade tem educação dentro da comunidade até o ensino médio, só tendo que emigrar para a cidade quando fazem faculdade. "Muitos deles estão fazendo (faculdade) e depois voltam para a comunidade para dar aula". Dos doze professores que lecionam na escola, dez são Kalunga. Ou outros dois não são Kalunga, mas moram na comunidade por serem casados com Kalunga. Os merendeiros e faxineiros também são da comunidade. Há duas escolas- uma municipal e outra estadual. A escola estadual foi construída com recursos de uma ONG inglesa, que a construiu e a doou para a comunidade.

As crianças também tem aulas de reforço escolar no horário contrário à aula pelo PETI. Na época de escola não vão para as roças, apesar de ter "criança que fica chorando para ir para a roça. Gostam de ficar lá comendo cana, banana, correndo...”. Segundo Seu Cirilo, as crianças estão livres do trabalho infantil, por que todos sabem que tem que estudar, e seus pais não querem perder a Bolsa Família. Enquanto conversávamos vi algumas crianças de cerca de 10 anos de idade correndo subindo uma serra que fica atrás do restaurante. Perguntei a ele o que eles faziam. Ele somente respondeu "Brincando. Esses meninos quando não estão na escola 
brincam o tempo todo correndo por aí". Cheguei a ter um ar de inveja das mães daqueles meninos, pois eles brincavam livremente e ela não tinha que se preocupar com violência ou com carros correndo na rua.

Pergunto a Seu Cirilo qual a principal fonte de renda das pessoas ali do Engenho. Ele acredita que muitos ainda tem os benefícios da seguridade social como principal fonte de renda, mas que espera que no futuro a renda principal da Comunidade deve vir do Turismo. Para ele, ainda tem muito potencial para desenvolver. Hoje eles fornecem alimentação para os turistas (R\$ 25,00 o almoço com frango caipira , arroz, feijão, salada, farofa de carne e legumes), fornecem minimamente estruturada área para Camping ( $\mathrm{R} \$ 25,00$ por barraca), cobram a entrada para as duas cachoeiras $(\mathrm{R} \$ 10,00)$ e o serviço de guia $(\mathrm{R} \$ 50,00$ para um grupo de até 5 pessoas). Esses preços não sofrem aumento há oito anos. Eles estudam aumentar os preços dado que a demanda tem crescido.

A agricultura e pecuária são basicamente de subsistência. Os excedentes são vendidos a turistas na loja de produtos sustentáveis Kalunga. São produções individuais. Cada qual produz o seu, sem organização coletiva. De 2006 a 2009 houve uma tentativa de produção por mandala. Eles vendiam por meio do Programa Nacional de Alimentação Escolar prefeitura. Mas pararam por problemas de transporte para buscar adubo e por falta de pagamento dos produtos pelo município.

Os vãos da serras são os lugares da roça. Tanto os de Monte Alegre, como de Teresina e Cavalcante produzem nos vãos, mas as áreas são de produção individual- cada família sabe qual canto pode produzir, é "hereditário", segundo ele. Nos vãos ele tem maior proximidade dos rios e a terra é melhor para

A agua é encanada da nascente da serra, descendo por gravidade. A encanação chega às 140 casas da comunidade, à escola e ao posto de saúde. Seu Cirilo diz que é de muito boa qualidade. "Filtrada por Deus, pela natureza".

Recebem benefício do Programa Bolsa Família e da Cesta do estado. O dinheiro da Cesta tem que apresentar o comprovante (?). O dinheiro é usado para comprar alimentos, material escolar... "O dinheiro ajuda muito". Quando falamos sobre o valor recebido pelo Bolsa Família, discutimos o número de filhos nas famílias. Ele disse que tem gente que recebe até 
$\mathrm{R} \$ 800,00$ de benefício, mas é por que tem mais de oito pessoas na casa. Perguntei se era comum, ele disse que não. Mas que passou-se um tempo sem ter muita criança na comunidade, mas, como os jovens estão ficando lá, agora está em uma fase de muita “afilhação". Tentei entender se ele achava se tinha alguma coisa a ver com receber o benefício do Bolsa Família, mas ele não mencionou isso em nem um momento. Pareceu ser natural mesmo que muitas meninas estejam em idade de estar "produzindo", como diz ele.

Até 2004, as meninas ou meninos de 12 anos iam para a cidade, trabalhar ou estudar. Hoje, “com o desenvolvimento, o ramo de vida é melhor aqui [...] tamo sendo autossustentável aqui. Quem saiu, quer voltar."

A assistência médica é regular no posto de saúde do Engenho- cerca de uma vez por semana o médico está lá para consultas. Mas sempre tem enfermeiros e agente comunitário, que são Kalunga também. Quando tem alguma emergência maior, eles ligam e o município manda um carro para buscar e levar no hospital. O posto de saúde também foi construído e doado pela ONG inglesa.

No entendimento de Seu Cirilo sobre o que precisa melhorar, eles precisam de crédito para investir em infraestrutura para turismo. O turismo, segundo ele, é o maior potencial de renda: "todo mundo tá ganhando, desde que tenha disponibilidade para trabalhar com o turismo todo mundo tá ganhando, seja quem vende um frango, seja quem vende uma vaca, seja quem vende coisas de horta, quem presta serviço na portaria, quem vai guiar, todo mundo tá ganhando, às vez tem uma pessoa trabalhando no restaurante e tem um outra lá trabalhando cuidando do filho de quem tá no restaurante, todo mundo tá ganhando". Ele pegou crédito de R\$ 5 mil com o Banco do Povo para comprar o equipamento do restaurante - geladeira e freezer. Comprou em um comércio em Cavalcante. Já quitou a dívida.

40 casas foram construídas pelo programa de habitação quilombola do Governo Federal. Ele conta explicando que a seleção foi feita pela própria comunidade, com critérios: muitas famílias ocupando uma casa só, falta de condição para comprar ou construir uma outra casa. Mas ele acha que a casa foi feita pequena e com os banheiros do lado de fora. Quase todas já foram aumentadas por eles, colocando o banheiro dentro. Eles foram informados que a nova etapa do Programa está chegando e todas as comunidades vão receber. Agora vai ser com banheiro dentro da casa, diz ele todo orgulhoso com jeito de quem está sendo ouvido. 
Seu Cirilo disse que "coisa boa demais também que teve com a vinda do Presidente Lula" foram os mutirões para emissão de documentos. Adultos que nunca tiveram documentação receberam RG e CPF. Hoje as crianças nascem e já tem certidão e muitos já tem CPF e identidade ainda pequenininhos.

Todos os que tem idade possuem aposentadoria rural, segundo ele. As mulheres recebem o auxílio maternidade pelo INSS de quatro salários mínimos, que correspondem aos quatro meses de licença maternidade, se conseguem comprovar que exercem atividade rural. "Tem umas que não dão sorte e não conseguem”. Perguntei a ele por que algumas não davam sorte e ele disse que é por que elas querem dizer que tem atividade rural mas não conseguem explicar o que fazem, na verdade é por que não plantam nem uma horta, segundo ele. As que plantam conseguem.

Perguntei a Seu Cirilo se tem muita gente recebendo a aposentadoria rural e ele disse que sim por que o povo lá vive muito. Perguntei a razão da longevidade e ele disse que é por que eles comem sem produtos químicos, não tem poluição, não tem violência, tem água boa e não tem estresse. Disse que o povo ainda morre muito é de chagas, pois algumas casas no Vão do Moleque e no Vão de Almas ainda são de palha, e de vez em quando um morre de derrame ou de câncer. Perguntei se os que tiveram câncer tiveram tratamento e ele disse lembrava de dois homens que até foram operados em Brasília, fizeram tratamento: " mas não teve jeito. Beberam muita cachaça e fumaram muito."

Mostrei a Seu Cirilo o livro de Mari Baiocchi com fotos da comunidade nos anos 80. Ele reconheceu algumas pessoas que já morreram, outras crianças que já viraram mães e pais. Perguntei a ele o que mudou. Como as fotos eram mais das festividades deles, ele disse que não mudou muito não. Eles tiveram desenvolvimento, mas a cultura deles continua. Eles continuam fazendo suas festas religiosas. Ali no Engenho a maior festa é a de Santo Antônio no mês de julho, quando muitos de todas as comunidades Kalunga, turistas e população local vão até lá. Seu Cirilo parece realmente estar focado no seu objetivo de desenvolver o turismo ali, pois enfatizou que a cultura deles é o fator que chama os turistas para lá. Por isso também eles não podem deixar morrer. 
Enquanto estávamos fazendo a entrevista, o Seu Cirilo teve que interromper duas vezes para resolver questões turísticas. Em uma terça-feira chuvosa, no prazo de 2 horas que durou a entrevista, chegaram dois casais de turistas. O primeiro queria almoçar na comunidade na volta das cachoeiras. Então Seu Cirilo teve que chamar sua filha, que é a cozinheira do restaurante, para acelerar o almoço. O segundo queria um lugar para acampar. Seu Cirilo disse que eles podiam escolher e ofereceu o lugar coberto onde há um fogão a lenha, parecendo um lugar onde se faz farinha, doces e outras coisas. O jovem casal pareceu feliz, não esperavam ter um local coberto para colocar sua barraca.

Perguntei a Seu Cirilo com quem mais eu poderia conversar. Eu disse que preferiria uma mulher. Ele disse que poderia ser uma professora da escola. Ou também poderia ser Dona Getúlia, sua ex-mulher, mãe de seus filhos, que, disse ele com muito carinho, sabe de muita informação de antes e de hoje.

\section{ENGENHO II, CONVERSA COM DONA GETÚLIA MOREIRA DA SILVA, 56 ANOS, CRIOU 15 FILHOS, MAS TEVE 10, SENDO QUE UM MORREU E ELA CRIOU MAIS 6 QUE ERAM SOMENTE DE SEU MARIDO.}

Dona Getúlia estava na frente de sua casa, lavando roupa e entrando e saindo da casa para olhar as panelas do almoço. Fiquei meio sem graça de atrapalhar a rotina de trabalho dela e disse que voltaria depois. Ela também meio sem graça disse para eu esperar só um pouquinho. Eu falei que tinha todo tempo do mundo. Fiquei andando na comunidade com Seu Cirilo, olhando e fotografando as grandes conquistas que eles tiveram nos últimos anos- escolas, postes de luz, agua encanada, orelhão, restaurantes, Centro de Atendimento ao Turista.

Então ela me chamou e disse que poderíamos ir conversando enquanto ela terminava o almoço. Me ofereceu milho cozido e começamos a conversar. Na primeira pergunta, já sabia que ia adorar conversar com Dona Getúlia. Para a pergunta “A senhora nasceu aqui?”, ela me diz que nasceu ali, depois rodou, rodou e voltou. Voltou e não sai dali nunca mais. Ela saiu por que, segundo ela, tinha que conhecer outros lugares e outras pessoas, estudar um pouco, mas que o clima dali, a água dali, ela não esquecia. "Bom ficar é no lugar onde a gente nasceu e criou e conhece".

Perguntei a ela qual tinha sido o maior ganho que ela via depois que as políticas públicas tinham chegado, ela para, pensa um pouco e diz: “é o direito de estudar na sua própria 
comunidade". Ela fala com muito orgulho que eles (os Kalunga) trouxeram a escola com o apoio da Fundação Cultural Palmares e do MEC, que os instruíram a pedir e como fazer. Eu percebo a felicidade dela de, mesmo percebendo a importância das instituições, sentir que os Kalunga são protagonistas no processo de desenvolvimento.

Depois fala da casas construídas pela FUBRA, contratada pelo Governo Federal. "O aglomeramento das casas foi melhor para o benefício da energia elétrica e da água encanada". Segundo ela, a comunidade ficou mais unida. Nas comunidades onde as casas são mais isoladas, longe umas das outras, é mais difícil chegar os benefícios. Importante também para a melhoria da qualidade de vida foi a construção dos banheiros, segundo ela: "é bom demais poder tomar banho no chuveiro quente, poder ir no banheiro dentro de casa. Nossa, é muito diferente!” Fala ela com emoção de quem está lembrando das dificuldades que já passou.

Ela diz que antes da construção as casas eram mais isoladas, como se fossem mini-chácaras. A vantagem segundo ela é que ela podia criar seus filhos sem interferência de ninguém, somente ela educava seus filhos. "Hoje os meninos ficam na casa de um e de outro e aprendem coisas que não foi a gente que ensinou", diz Dona Getúlia com todo jeito de mãe que sabe o que é melhor para seus filhos.

Ela teve dez filhos, sendo que um morreu, e criou outros seis do primeiro casamento de seu marido. Ela conta que morava na roça o tempo todo. Hoje o povo mora na roça e "cá fora" uns meses. Naquela época era o tempo todo na roça, pois tinha que trabalhar muito para comer. Não tinham renda de lugar nenhum. Eles plantavam tudo que comiam, e eram muitas bocas para comer: "Não tinha dinheiro não, tudo que precisava tirava daquil". Até roupa? Perguntei. Sim, e ela me mostra fotos dela e de sua irmã fazendo tear. Elas plantavam algodão e faziam roupas e cobertas. Mas passavam muita dificuldade. Ela disse que era muito frio antes e as roupas não eram suficientes.

Perguntei sobre os estudos de seus filhos. Ela disse que "escola é que era pouca". Não tinha professora dentro da comunidade. Então uma professora ia lá de vez em quando e passava um tempo lá ensinando os meninos. Também não tinha estrada que prestasse.

Perguntei como ela percebe a diferença para a criação de seus netos hoje. Ao que ela me disse “ Hoje todo mundo é rico, não tem ninguém pobre”. A pobreza que tanto castigou Dona 
Getulia para criar seus filhos hoje alivia suas filhas. Suas filhas tem profissão. Duas são professoras na escola da comunidade. Outra é cozinheira do restaurante. Seus netos vão para a escola dentro da comunidade, tem material escolar, roupas e sapatos. Ninguém sofre mais por falta de dinheiro. Quem não tem um salário fixo que permite ter uma boa renda familiar, recebe o Bolsa Família, que segunda ela, ajudou demais as mulheres: "Antes as mulheres tinham que se virar para conseguir um dinheiro."

Ela fala que "a decisão mais acertada do Presidente Lula foi ter dado o cartão para as mulheres". Ela acredita que se fosse para os homens, o uso do recurso seria bem diferente. "Só quem sabe da necessidade de cada filho é a mãe. A mulher pode ter dez filhos e ela sabe do que cada um precisa, o pai não sabe.” Dona Getúlia dá um sorriso branco enorme e diz "por isso que eu amo aquele Lula. Ele pensou nas mulheres". E ela me diz que a energia elétrica foi cadastrada também no nome das mulheres, assim como as casas que foram construídas, o que provocou mudanças na cultura tradicionalmente machista. "Antes quando a mulher queria se separar, ela tinha que voltar para a casa dos pais. Hoje a casa é dela. O homem que sai. Ela fica com a casa e com os filhos". Ela fala de sua alegria de ver como as mulheres hoje são iguais aos homens. Ela se sente muito orgulhosa ao falar nisso.

Pergunto o que precisa melhorar e ela diz que precisam de mais médicos. Melhorou muito. "Se comparar com antes que não tinha nada, melhorou muito. Tem posto de saúde aqui dentro. Já teve médico uma vez por semana, já teve médico visitando as casas nos últimos anos". Por alguma razão, que parece ser a reforma que está passando o posto, as visitas dos médicos pararam. Mais tarde conversando com a médica do Programa Mais Médicos, descubro que o médico que está responsável pela visita aos Kalunga teve que ir para Cuba fazer uma cirurgia e aguarda recuperação. Eles estão sem visita de médico há cerca de 45 dias, por que ele foi na época no natal.

Acrescentou que o Agente Comunitário de Saúde é outra pessoa importante para a comunidade, pois ele traz informações importantes, traz a vacinação e solicita médico ou ambulância quando eles precisam.

Perguntei a ela como eles fazem para ir a outras comunidades ou ir à cidade, se tinham transporte e estrada. Ela disse que a estrada melhorou muito do Engenho para a cidade. Para as outras comunidades, como o Vão do Moleque e o Vão de Almas, ainda precisa melhorar. 
Já houve ônibus coletivo da prefeitura duas vezes por semana do Engenho. Depois que mudou o prefeito, o ônibus parou e ela não sabe dizer por quê. Hoje tem um ônibus privado, que cobra $\mathrm{R} \$ 10,00$ cada trecho, somente às sextas-feiras. As pessoas vão de manhã e voltam no fim do dia. Mas muita gente já tem carro. Ela contou os dedos e contou umas dez famílias que tem carro no Engenho, incluindo uma filha sua. Assim, quando eles precisam, sempre tem alguém para levar na cidade. Eles também usam bicicleta e cavalo. Mas o cavalo não vai para a cidade. Só para as outras comunidades ou para a roça.

Ela diz que por causa da idade dela (ela tem 56 anos, a pele não aparenta, mas o sofrimento castigou seu corpo e ela apresenta alguma fragilidade ao andar e se mover) ela quase não sai dali. Ela gosta é de passear na casa dos filhos ali mesmo, fazer as ladainhas na hora do almoço nas casas, as novenas, as rezas na igreja, e de vez em quando gosta de televisão.

Peço para tirar uma foto dela em sua casa. Ela me olha e quando penso que ela vai dizer que não gosta de foto, ela me diz "Eu gosto é de foto viva." Eu, sem entender, olho para ela e pergunto como é a foto viva. Ela diz: "Com o verde. Vamos tirar lá fora, de frente para aquela serra ali, que é bonita". Me surpreendeu. Eu tirei a foto e admirei não só a serra mas a capacidade dela de viver ali e ainda saber admirar a serra atrás de sua casa, como se não a visse todos os dias.

\section{ENGENHO II, DIA 11 DE FEVEREIRO DE 2015}

\section{ENGENHO II, CONVERSA COM RITA PEREIRA TARTULIANE, 44 ANOS, 8 FILHOS, SENDO 7 VIVOS.}

Novamente a sorte veio ao meu encontro no território Kalunga. Por não ter agendado entrevista alguma, a fim de poder decidir o melhor rumo a se tomar de acordo com as respostas que eu teria ao chegar no território, fui novamente para o Engenho, com esperança de entrevistar as professoras segundo sugestão de Seu Cirilo. Mas no caminho, mudei de ideia. Seu Cirilo havia falado tanto do turismo que me fez querer visitar as cachoeiras que fazem daquele lugar o principal ponto turístico do município. Ao mesmo tempo, eu não queria deixar de realizar minhas entrevistas. Pensei que o meu guia teria que ser alguém que eu pudesse entrevistar, preferencialmente alguém que pudesse me falar sobre as diferenças entre o acesso a políticas públicas no Engenho e no Vão do Moleque, já que todos estavam me dizendo que eu não deveria ir ao Vão do Moleque, pois não se tinha acesso de carro. 
Na estrada para o Engenho, quase no mesmo ponto onde encontrei Seu Cirilo no dia anterior, vejo uma mulher andando e ofereço carona. Era Rita, Kalunga nascida e criada no Vão do Moleque e que estava no Engenho há seis anos trabalhando como guia. Não acreditei na minha sorte. Ela me pergunta se eu queria que ela me guiasse para as cachoeiras e eu digo que seria um grande prazer e pergunto se ela se importava de conversar comigo sobre temas de minha pesquisa enquanto fazia seu trabalho. Ela, com um sorriso branco e largo, me responde muito sabiamente com outra pergunta: “o que é mesmo que você pesquisa?” Expliquei a ela meu interesse em saber se as políticas públicas, em especial aquelas do Programa Brasil Quilombola e do Brasil Sem Miséria, tinha chegado no território e como eles achavam que a vida deles tinha melhorado. Então ela diz que pode conversar sim já adiantando que no Vão do Moleque tudo era muito diferente do Engenho. "Então você é a pessoa perfeita para me guiar para a cachoeira hoje", disse a ela.

Rita muito cuidadosa pediu que passássemos em sua casa primeiro por que ela tinha que pegar sua mochila com seus equipamentos de guia. Ela vestia sua bota de trilha, calça jeans, camisa e lenço verdes do uniforme de guia com o nome Quilombo Kalunga. Sua casa era uma casa pequena branca de janelas azuis de alvenaria e telhado de telhas de cerâmica, com uma caixa d'água e energia ligada à casa. Perguntei a ela se tinha sido construída pelo Programa de Habitação do governo e ela diz que sim, e que seu marido tinha trabalhado na construção, pois ele fora contratado para construir as casas por ser pedreiro, tendo recebido treinamento específico.

Então ela diz que temos que passar pelo CAT-Centro de Atendimento ao Turismo para eu assinar o livro de visitantes e pagar a entrada das cachoeiras- R $\$ 10,00$ para as visitar as duas. O pagamento do serviço de guia seria pago diretamente à Rita ao final do passeio- $\mathrm{R} \$ 50,00$. Tive que esperar dois casais que estavam na minha frente para assinar o livro. Enquanto isso vi que tinha um bonito folder com as fotos das cachoeiras e das paisagens e frutos do cerrado. Perguntei quem tinha feito e Damião, filho de Seu Cirilo que trabalha na portaria, me informou que tinha sido uma mulher da Universidade de Goiás, perguntei e ele confirmou que era um projeto da Professora Maria Geralda. Eles também tinha o passaporte Kalunga à disposição, outro projeto da UFG coordenado pela Professora Maria Geralda, mas não souberam me dizer o preço para eu poder comprar. Ao assinar o livro, notei que em uma quarta-feira, 9h da manhã, oito pessoas já tinham assinado o livro de entrada. Era pessoas de 
Brasília, Rio de Janeiro e São Paulo, o que mostra o potencial de avanço em geração de renda por meio da atividade turística no Território Kalunga. Seu Cirilo parece ter toda razão ao colocar esperanças no empreendimento de turismo.

Passamos no restaurante da Elizete para encomendar o almoço. Rita informa a ela que chegaríamos às $16 \mathrm{~h}$ para almoçar e ela diz que podemos seguir despreocupadas que o almoço estará pronto quando chegarmos. Vi que os outros visitantes também passaram em restaurantes dentro da comunidade para encomendar seu almoço.

Os outros dois casais seguiram em carro tipo pick up conduzido por uma guia. Perguntei a Rita de quem era aquele carro, se era do CAT. Ela diz que não, que era da própria guia. Ela havia comprado financiado. $\mathrm{O}$ fato de ela ter um carro para levar os turistas dá a ela grande vantagem, pois o carro dela pode atravessar um dos córregos para chegar à cachoeira Santa Bárbara, o que deixa somente cerca de $1 \mathrm{~km}$ de trilha a pé. Quem vai de carro de passeio deve parar antes do córrego e andar $5 \mathrm{~km}$ até chegar à cachoeira. Como eu estava em um jeep $4 \times 4$ próprio, eu e Rita pudemos atravessar o córrego com o incentivo e orientação dela. Rita desceu do jeep antes de eu atravessar, verificou a profundidade do córrego já que havia chovido desde a última vez que ela havia estado ali, moveu algumas pedras e mostrou o caminho que eu deveria seguir. Muito bem orientada, atravessei sem perigo algum.

A conversa com Rita sobre os temas da pesquisa mais diretamente começou ainda na trilha a pé por iniciativa dela mesma. Vi que ela estava ansiosa para falar sobre o quanto a realidade no Vão do Moleque era diferente daquela do Engenho, onde tudo estava muito organizado. Então pedi a ela autorização para começar a gravar andando mesmo, já que ela me dava muitas informações relevantes. Ela não se importou e começou a falar novamente quando avisei que já estava agravando, muito cooperativa.

Primeira ela se apresenta: "Eu sou Rita, nascida no Vão do Moleque, ganhei quatro filhos no Vão, e os outros quatro foram na cidade". Seus quatro primeiros partos foram feitos por sua tia parteira, que nunca deixou uma criança morrer, conta ela. Mas o pior para Rita é o isolamento do Vão do Moleque devido ausência de pontes: “é o córregos que nos prende. [...\} às vezes vem as verbas mas num chega esse trabalho pra nós". Outro limitador da liberdade de ir e vir relatado por Rita é a falta de transporte público. "Se a gente quer ir e quer vim a gente tem que pagar $\mathrm{R} \$ 25,00$ para ir e $\mathrm{R} \$ 25,00$ para voltar do Vão do Moleque até 
Cavalcante". O transporte é por meio de um caminhão, carinhosamente chamado de pau de arara. "E nós agradece por que nós não temos outros. Não tem outra solução. Como a estrada é ruim, não tem manutenção a gente até que agradece mesmo é o caminhão por que um onibus tem mais facilidade de tombar do que o caminhão".

A falta de liberdade para ir e vir devido à falta de pontes, estrada e transporte é a principal razão dos Kalunga saírem do Vão do Moleque. "Foi por isso que eu abandonei o meu lugar, por causa do transporte. "O dinheiro de duas diárias de serviço que era para eu ajudar na minha roça eu tinha que gastar em transporte..."

Rita recebe o Bolsa Família. Antes recebia $\mathrm{R} \$ 244,00$ mas agora diminuiu mas ela não sabe dizer o motivo. Perguntei se seria por que seus filhos terminaram o ensino médio mas ela não soube dizer. Mas disse que o valor faz falta, pois ela continua tendo que dar conta das despesas de toda a casa. Além do Bolsa Família, a família de Rita conta com a aposentadoria da mãe dela, com o Beneficio de Prestação Continuada da sobrinha que é portadora de deficiência, a renda do trabalho de Rita como guia e de seu marido como pedreiro. Devido à pouca demanda, Rita chama o trabalho dela e de seu marido de "bicos". Como a renda não é regular, o dinheiro não é muito. Mas apesar das despesas com tantos filhos e da renda baixa, ela acha que vive bem: "eu não devo reclamar muito não, por que eu passei por dificuldade mais difícil, muito mais difícil e mais precária do que eu tô hoje. Hoje eu tenho que agradecer a Deus e me comparar por que hoje eu sou uma pessoa rica pelo o que já passei. E muito obrigada". Abre um sorriso.

Rita afirma que a alimentação de todos os dias é garantida. Ela diz que não deixa sua mãe nem seus filhos sem verdura e de vez em quando tem uma carne. "Nós já sofremos demais. Já tá o fim do sofrimento". Ela diz que no passado, quando moravam no Vão do Moleque, ela chegou a passar três dias deitada em uma cama sem comer nada. Às vezes quando a fome era grande, eles comiam coco que catavam no mato até que arrumassem outra solução. "As vezes a gente já chegou a comer o fubá do coco, que é comida horrível para a gente comer. A gente come se não tiver outra solução para não morrer de fome."

Perguntei a ela se hoje no Vão do Moleque alguém ainda vive assim. Ela disse que acha que não, pois quem não tem um salário, tem o Bolsa Família, consegue uma renda, mesmo que pouca, do que planta, tem a aposentadoria rural para alguns idosos e o benefício de prestação continuada para aqueles que possuem deficiência. "Já ninguém tem as dificuldades que tinha 
antes de sobrevivência. Que era difícil era, muito difícil. Eu cheguei muitas vezes a chorar de fome. Por que a fome dói”. Hoje ela diz que não vê mais aquele sofrimento que era antes.

Perguntei a Rita sobre a vida dela no Engenho e ela diz que o Engenho é o paraíso no meio do deserto. Segundo Rita, lá todo mundo é feliz por que ninguém lembra mais do sofrimento. Perguntei a ela por que ela achava que no Engenho estava tão diferente. Rita considera que foi a vontade de um líder de fazer melhor pelo seu povo que fez a grande diferença. "Aqui teve aquela pessoa que enxergou, teve aquela atitude de trazer algum benefício de melhor. Ele não quis só pra ele". Ela diz que Seu Cirilo e o Santo reconheceram que o lugar deles precisava de receber as politicas públicas do Governo. Ela afirma que eles lutaram por todas as comunidades, não só pelo Engenho. Mas a que foi mais beneficiada foi o Engenho devido à persistência de Seu Cirilo. Ela acredita que se houvesse uma pessoa dentro do Vão do Moleque para seguir com persistência na luta, hoje o Vão estaria na mesma condição de qualidade de vida. Ela diz que Seu Cirilo era sozinho na sua luta, que no Vão do Moleque não tem liderança. Muitos de lá do Vão criticam o fato de só o Engenho receber as políticas, mas que ela viu, depois que foi morar no Engenho, que faltou liderança no Vão, faltou coletividade para lutar por seus direitos. Ela acredita que os avanços do turismo também podem ser estendidos ao Vão, pois lá, apesar de não possuir cachoeiras, possui paisagens e rios que substituem qualquer cachoeira.

Ela acredita que a organização do turismo no Engenho e as políticas que permitiram estruturar essa organização, como a estrada, a energia, a água, foi o que melhor pode acontecer no Engenho. Segundo ela, todos conseguem alguma renda por meio de seu trabalho, seja do artesanato, seja da cozinha, seja do serviço de guia.

Rita começa a falar da importância de se ter conhecimento. A população do Engenho recebeu muito treinamento para organizar o trabalho de turismo. Ela afirma que é analfabeta mas que sabe muita coisa, que aprendeu com o mundo. "O mundo foi meu caderno e minha caneta". Ela não frequentou a escola. Somente depois que ela já era mãe é que apareceu a oportunidade de estudar, mas aí ela já não tinha mais cabeça para ficar na escola, pois seu foco era a criação de seus filhos. Era trabalhar para não ver seus filhos passarem o que ela passou. Ela disse que foi criada por sua mãe sozinha tendo que pedir comida para os vizinhos para seus filhos. E aquilo doía. "Desde que eu fui mãe, a coisa que eu mais foquei foi 
trabalhar para os meus filhos, para eu não depender de pedir uma bocada de comida para ninguém. Eu odeio pedir."

Todos seus filhos frequentaram ou frequentam a escola. Dois já terminaram o ensino médio, fizeram concurso para trabalhar e passaram. Sua filha de 18 anos passou no vestibular para fazer faculdade de serviço social. Ela não sabe como ela vai fazer para pagar a faculdade. Apesar de trabalhar em uma loja de telefone celular em Goiânia, a salário não é suficiente. Ela fala com muito orgulho do esforço que sua filha sempre teve para estudar. Ela diz que ela só ajudava nas tarefas de casa depois de terminar de estudar.

$\mathrm{Eu}$ disse a ela que torcia para que sua filha fizesse essa faculdade e voltasse para Cavalcante para trabalhar na Assistência Social levando seu conhecimento para melhorar a vida dos Kalunga. Ela sorri e diz "Deus que ilumine”. Mas depois, entristece um pouco na esperança e diz que não sabe se ela conseguiria fazer alguma coisa por que todo mundo que quer fazer algo e entra na prefeitura, rapidamente sai de lá, é mandado embora. "O comentário que a gente vê é que ali rola uma máfia, tudo vai para o bolso deles". Pergunta para mim se eu sei o que é máfia. Eu digo que sim. Ela olha e diz: “Ali tem uma máfia. A pessoa que persiste é cassada." Assim ela diz que prefere que sua filha fique por Goiânia mesmo, pois não tem esperança que mude alguma coisa ali. Ela afirma que todos os prefeitos que entram "cresce o olho e aumenta a barriga".

Rita muito sabiamente me informa que todo o dinheiro que entra na prefeitura está em um site, que ela não lembrava o nome, mas ninguém sabe para onde vai aquele dinheiro. Ela diz que entra muito projeto para a prefeitura de Cavalcante e ninguém sabe o que acontece com o dinheiro. Mencionou um projeto municipal chamado cheque-reforma. Muitos fizeram a inscrição para obter recursos para realizar reformas em suas casas, mas ninguém teve resposta. "Ninguém nunca viu esse dinheiro. Para onde esse dinheiro foi? Se ele veio, ele parou aonde? Na prefeitura".

Isso muito me preocupou por que a gestão da prefeitura de Cavalcante é assunto recorrente com todas as pessoas que conversei, no sítio Kalunga e na cidade.

A fim de voltar para o tema de acesso a serviços e políticas públicas, perguntei a Rita se os assistentes sociais do Centro de Referencia da Assistência Social - CRAS vão até o Engenho 
para visitas domiciliares, já que lá não tem um CRAS. Rita não sabia o que era CRAS e disse que nunca viu ninguém ir lá. A única pessoa que vai nas casas é o agente de saúde, que é da própria comunidade, mas que ninguém fiscaliza para saber se ele está trabalhando (outra crítica à falta de interesse da gestão do município). O acesso ao serviço de assistência social somente é possível se a pessoa for até Cavalcante.

O acesso ao serviço de saúde é facilitado por agentes de saúde da própria comunidade. Mas apesar de haver um morador que é agente de saúde, Rita não acha que ele atende a todas as casas. Ela entende a ideia de que um morador poderia fazer melhor o trabalho por conhecer todos que lá habitam, porém não acha que ele atende, pois nenhum agente bateu em sua porta de casa para perguntar como ela estava, para medir sua pressão. Se ela quer se consultar, ela tem que ir na cidade, pois o posto de saúde lá do Engenho está fechado a seis meses devido à reforma. O médico do programa Mais Médicos visitava a comunidade duas vezes por semana em 2014. Mas parou no fim do ano. (Mais tarde eu soube por uma outra médica do programa Mais Médicos que o médico que atende no Engenho é cubano e teve que ir Cuba para fazer uma cirurgia, e quando retornasse iria para lá todos os dias a partir deste ano)

Novamente pergunto sobre o benefício recebido por meio do Programa Bolsa Família, pois queria saber um pouco sobre o uso do recurso. Rita é beneficiária do Bolsa Família desde 2003, ou seja seus filhos que terminaram o ensino médio foram beneficiários. Ela diz que com o recurso ela comprava material escolar para seus filhos além de sandálias e algum item de alimentação. Ela já conseguiu comprar com o recurso do Bolsa Família camas e colchão para cada um de seus filhos. O único mal uso que ela acha que pode ter feito foi um aparelho de DVD que seus filhos queriam. Mas ao mesmo tempo ela diz que acha que não foi mal uso por que era o que seus filhos queriam. E ela tinha o dinheiro e comprou. Ficou feliz.

Ela novamente fala da diferença da vida que ela teve- ela só conseguiu comprar seu primeiro sapato aos 11 anos quando foi trabalhar- e da vida que ela está conseguindo dar a seus filhos. Seus filhos tem um vida boa, ela considera.

Perguntei a Rita se seus filhos começaram a trabalhar tão cedo quanto ela e ela fala longamente sobre a importância de incentivar os filhos a estudar ao mesmo tempo que se deve ensiná-los a trabalhar. Ela discorda de o Governo proibir as crianças de trabalhar. Ela entende que eles deveriam trabalhar no contra turno da escola, pois eles ficam nas ruas e acabam se 
envolvendo em violência e "aprendendo o que não presta", no caso dos meninos que moram na cidade.

Os filhos de Rita moram em Cavalcante para estudar, pois Rita acha que o ensino dentro do Engenho não é tão bom. Ela acredita que eles terão uma vida melhor se forem para a cidade logo cedo. Então ela tem uma casa em Cavalcante (não ficou claro se é alugada ou se é própria) para sua mãe, sua sobrinha deficiente e seus filhos, pois assim sua mãe fica mais próxima de assistência médica. Ela tem muito medo de seus filhos se envolverem com má companhia no horário que não estão na escola. Ela incentiva que seus filhos trabalhem dentro de casa e procurem "bicos" para ganhar algum dinheiro, por exemplo capinando um lote de um vizinho. Ela diz que sempre fez isso e nunca se arrependeu. Seus filhos sempre a ajudaram a trabalhar e nunca tiveram necessidade de roubar.

Os meninos que moram no Engenho normalmente ajudam os pais a trabalhar na roça ou fazer as tarefas de casa, mas estão todos indo para escola. "Aqui ninguém tira os filhos da escola para por os filhos para trabalhar". Primeiro a escola, depois as tarefas da escola, depois lavam o uniforme da escola e ajudam na casa. "Quem sofreu o analfabetismo sabe o quanto dói. Por isso nenhum mãe ou pai faz isso. Tem muitos pais e mães analfabetos nessa nossa região e eles sabem o quanto dói a gente ser analfabeto".

Rita olha bem dentro dos meus olhos e fala várias vezes o quanto dói ser analfabeto como quem pensa "você não sabe do que eu estou falando, preciso repetir para você entender". Ela repete "ser analfabeto dói". Conta que às vezes é chamada para uma reunião e as pessoas distribuem algum papel explicando para que é a reunião, mas como ela não sabe ler, ela fica só segurando o papel ao invés de ler e prestar atenção.

Ela conta também que às vezes compra produtos vencidos no supermercado por não saber ler a validade. Conta ainda que já chegou em algum lugar e perguntou o preço de algum produto "Quanto que custa essa garrafa d'água?” e a pessoa respondeu, “o preço está bem aí na parede". Ela diz indignada, "eu tô vendo o preço ali mas se eu não sei quanto que é, o meu direito é de perguntar". Ela afirma novamente me olhando com força nos olhos "é muito doído". 
Ela diz que ninguém precisa hoje tirar os filhos da escola para trabalhar. Ela diz que no passado as pessoas não tinham oportunidade de colocar os filhos para estudar, primeiramente, e , segundo, não pensavam que os filhos iam sofrer. "Os povo de antepassado só pensava em morrer, eles não pensava no futuro". Ela acredita que antes as pessoas nem eram registradas no Cartório por que os pais achavam que eles não iam viver tanto, que não iriam precisar. Citou o exemplo de sua mãe, que somente foi registrada há cerca de 10 anos, aos 69 anos, por iniciativa de Rita.

Perguntei a ela se as pessoas lá tem vivido muito. Ela diz que razoavelmente, pois as comidas hoje possuem muito veneno. As comidas que eles plantam são as únicas que eles comem sem veneno. O que eles compram na cidade possuem veneno, principalmente a carne por ter a vacina. "Acho que hoje nós não temos mais segurança de nossa vida. Infelizmente nossa carne já era. Acabou." Ela diz que antes o pessoal vacinava o gado com uma casca de uma certa árvore, que ela chamou de "casca de pau", que era socada com sal e dada ao gado para comer para evitar febre aftosa. A relação era somente com a natureza. Por isso, para Rita, a alimentação que a cidade traz para o território não é segura.

Conversamos um pouco sobre a água. No Engenho, todos tem acesso à água encanada, que vem direto da nascente na serra. Porém, no Vão do Moleque, os moradores, em sua maioria, precisam ir buscar a água no rio. Alguns precisam andar dois a três quilômetros para buscar água, e voltam a mesma distância carregando o balde na cabeça. Na época da seca, eles precisam ir buscar água no lombo do burro com tambores de 20 litros. Ela diz que ela nunca teve o animal e sempre carregou esses tambores nas costas mesmo quando morava lá. Hoje ela tem a água encanada no Engenho e lava a roupa em tanquinho em casa mesmo, diferentes das mulheres do Vão que tem que lavar no rio.

Rita diz que hoje sua qualidade de vida melhorou muito depois que foi morar no Engenho. Hoje ela não tem o sofrimento que tinha antes. As mulheres do Vão precisam carregar água na cabeça, carregar roupa para lavar no rio, passar horas lá lavando e esfregando e depois carregam a roupa molhada pesada para casa. Ainda, carregam lenha para cozinhar. "As mulheres de lá ainda estão isoladas", ela diz. 
Pergunto a ela sobre a energia elétrica no Vão do Moleque e ela conta a mesma estória triste contada por tantos sobre os postes colocados no Vão do Moleque em 2004, cerca de $30 \mathrm{~km}$, porém sem ligação de rede. "Quem tá usando a rede? Cipó!"

Rita tem consciência de que algo muito errado ocorreu. Ela pergunta "Para onde foi a verba? Não mandaram a verba só pela metade.”

Já que Rita está falando do sofrimento dos Kalunga no Vão do Moleque, mais uma vez ela sente vontade de falar sobre a estrada. Sabendo da importância da participação social, ela diz que o sonho dela era acompanhar alguém para filmar e fazer uma reportagem acompanhando a travessia dos Kalunga para o Vão do Moleque. "Para as pessoas verem o sofrimento que é". São $140 \mathrm{~km}$ de Cavalcante até lá e é preciso atravessar cinco rios sem ponte, pois só foi feita a ponte do Rio Prata.

Nesse momento a gente resolve dar uma parada. Imagino que ela já devia estar muito cansada, pois ela falou sem parar por mais de $1 \mathrm{~h} 30$. Parecia que ela sentia vontade de fazer esse desabafo com alguém. Ao mesmo tempo, parecia que ela tinha esperança de que a voz dela chegasse a algum lugar. Que pudesse em algum momento fazer a diferença.

Mergulhei na cachoeira de Santa Bárbara também com a cabeça exausta por receber tanta informação com uma carga emocional tão grande que ela passou. Também desejei que essa pesquisa pudesse interessar aos gestores do MDS, do MDA ou da SEPPIR e que pudesse de fato causar algum evento de mudança no espaço Kalunga a fim de melhorar a qualidade de vida daqueles Kalunga que hoje não tem acesso a serviços públicos básicos, o que impede que eles vivem a vida do jeito que eles valorizam.

Eu e Rita conversamos o dia inteiro, mas sem a preocupação de gravar, pois já tínhamos esgotado o meu roteiro de temas de interesse para a pesquisa, achava eu. Quando fazíamos a trilha para a cachoeira da Capivara, a segunda no roteiro das cachoeiras dentro do Engenho, Rita me mostra todas aquelas serras e aponta para o lugar das roças plantadas por eles, nos vãos das serras. Diz "é muita roça espalhada". Depois de olhar um tempo ela me diz que sempre ficava pensando sobre seus antepassados que cruzaram aquelas serras de pedra descalços andando dias e noites sem parar, fugidos, com medo de "levar peia", para chegar ali. Eu disse a ela que era uma história para se orgulhar. Ela então diz, "é, mas sabe que eu já 
senti medo de ser escravizada de novo?". Só olhei para ela e perguntei "quando foi isso Rita?". Ela diz "quando eu fui trabalhar na cidade. A mulher queria que eu fizesse o serviço da casa de uma semana em um dia, o serviço de um dia em uma hora, e me tratava que nem cachorro. Pagava bem pouquinho, quase nada. E eu pensava, 'essa mulher vai me escravizar de novo'. E eu só ficava por que tinha que comer."

Me senti devastada por Rita ter tido esse medo. Mas não podia discordar dela. Aquela mulher estava escravizando-a. Perguntei a ela se hoje ela ainda sente que alguém pode se sentir assim. Ela diz que não por que hoje ninguém mais é miserável. Pelo menos com o Bolsa Família, as pessoas tinham o mínimo para comer e não precisava ficar nesse tipo de trabalho. Fiquei mais aliviada, pelo menos uma política pública está alcançado bem seu objetivo de expandir as liberdades das pessoas. Lembrei de Dona Getúlia que disse que hoje todo mundo é rico.

Ser rico no conceito de Dona Getúlia e Rita é não passar necessidades básicas como falta de alimento e vestiário. Mas os Kalunga anseiam por qualidade de vida de fato, com liberdade para ir e vir, com acesso frequente a serviços de saúde e educação de qualidade, com acesso à agua potável dentro de casa, com acesso a energia elétrica, cuja ausência limita tantas outras liberdades. Tendo consciência de que o Estado deve suprir sua população com infraestrutura e serviços públicos básicos, os Kalunga do Engenho mostram sua insatisfação com os governos local, estadual e federal perante à situação dos outros povoados que ainda não tiveram aceso às politicas publicas.

Apesar de todos dizerem que era impossível ir ao Vão do Moleque no meu carro, depois da conversa com Rita, eu não tive dúvidas, eu tinha que ir ao Vão do Moleque.

\section{VÃO DO MOLEQUE, DIA 12 DE FEVEREIRO DE 2015}

\section{VÃO DO MOLEQUE, CONVERSA COM DONA AIMIRAM E MANOEL DOS SANTOS BORGES,}

Como a sorte estava ao meu lado, no dia anterior, fazendo um lanche na praça de Cavalcante com uma amiga que mora na cidade e ela me apresentou o Beto Baiano, que passou por lá. Beto, que é de Salvador, tem uma empresa de turismo na cidade, por isso conhece muito bem 
todo o território Kalunga. Beto demonstrou muito interesse na minha pesquisa. Me fez muitas perguntas sobre políticas públicas. Ao final, minha amiga, que já havia me aconselhado a não ir ao Vão do Moleque, pergunta a ele "Beto, a Iara consegue ir até o Vão no carro dela?". Ele hesita para responder, e vem com a melhor frase de todas: "Eu vou com ela. Nesse carro $4 \times 4$ a gente consegue". Fiquei muito feliz, pois ir embora sem ir ao Vão seria frustrante para a pesquisa. Marcamos então de sair no dia seguinte às 8 h30.

Mais ou menos como planejado, conseguimos sair de Cavalcante às 9h. Quando a estrada começou a piorar um pouco, entreguei o volante para o Beto, já que ele conhece melhor os caminhos para não atolar ou não cair dentro das valas.

Há dois caminhos para ir ao Vão do Moleque, um percurso "por fora" de $140 \mathrm{~km}$ de estrada mais ou menos em condição de passar de caminhão ou caminhonete, mas que tem que atravessar o Rio Corrente. Como não foi construída a tal ponte, cuja verba sumiu, em época de chuva não é possível atravessar. Então tivemos que pegar o outro percurso, "por dentro", que é um grande atalho de somente $65 \mathrm{~km}$, mas cuja estrada nunca foi patrolada. A estrada foi aberta pelos próprios Kalunga por meio de arrecadação de recursos individuais para pagar diárias de um trator de esteira. Atravessa-se cerca de 15 córregos- chegou um momento que eu parei de contar- cheios de pedras grandes, em um caminho íngreme, cheio de valas, de pedras, e declives imensos. Levamos $3 \mathrm{~h} 30$ para percorrer os $65 \mathrm{~km}$ de estrada de chão e chegar ao Vão.

Chegamos exatamente às $12 \mathrm{~h} 30$ na casa de Dona Aimiram, que recebeu o Beto com um sorriso enorme, convidando-nos imediatamente para entrar, reclamando que, se tivesse sido avisada, tinha preparado um almoço para nós. (Naquele momento eu soube que tinha ido com a pessoa certa, pois ser Beto é muito querido. Parece conhecer todo mundo e saber de seus problemas.)

Ao entrarmos na casa, construída de concreto e telha pelo Programa de Habitação, Beto foi direto para o fogão à lenha dizendo que nós estávamos com fome e que tínhamos ido para almoçar, apesar de não termos avisado. Ela achou que sua comida estava simples demais e ficou meio embaraçada, mas Beto, muito extrovertido, disse que não era para ela se preocupar com nada, que ela só tinha que conversar comigo, que eu tinha ido lá somente para conhecêla, e começou a lavar as louças que estavam em sua pia. 
A comida estava deliciosa: frango com açafrão, arroz, abóbora, feijão, e quiabo. Eu disse a ela que se ela chegasse em minha casa naquele horário de surpresa, ela não iria encontrar um banquete como aquele para comer. Estava de fato delicioso, principalmente com a pimenta feita por ela mesma. Ainda, comi goiaba de sobremesa que sua filha apanhou para mim.

Aquele dia era um dia especial para os moradores do Vão, pois estavam sendo colocadas cisternas de plástico para captação da água de chuva do programa de acesso à água do Ministério da Integração nas casas, o que pudemos ver no caminho.

Então quando apresentei o tema de minha pesquisa, Dona Aimiram falou especialmente da alegria de todos eles com a chegada das cisternas. 50 cisternas estavam sendo instaladas. No Vão há 60 casas construídas com concreto e telhado pelo programa de habitação. As outras 10 que não receberão a cisterna possuem algum tipo de arranjo próprio para captação de água, que é o caso de Dona Aimiram, que por morar perto de uma nascente e no pé da serra, comprou mangueiras e puxou a água. As casas com telhado de palha, ou seja as mais vulneráveis, ficarão de fora do programa, pois não é possível captar a água nesse tipo de telhado. As casas que não tem acesso a carro não foram beneficiadas pelas casas. Somente às que moram na beira da estrada.

No entanto a conversa foi rapidamente para o problema relatado por todos como o grande entrave para a qualidade de vida dos Kalunga do Vão. "Eu costumo falar que nossa saúde, nossa educação, nosso desenvolvimento em geral está relacionado à estrada", disse Dona Aimiram.

Ela contou que pessoas morreram por causa da falta de estrada. Em 2014, uma criança de dois anos morreu por que estava doente, choveu muito, o Rio Paranã encheu, não tendo como levar a criança para cidade, e ela veio a falecer. Ela disse que se chovesse enquanto eu e Beto estivéssemos lá, a gente ia ter que ficar acampado esperando a estrada secar por alguns dias. Segundo ela, ninguém passa na estrada quando chove. Eles se sentem impotentes por não poderem ir nem vir quando estão "ilhados".

O único transporte que há é o caminhão "pau-de-arara” duas vezes por semana. Ele vai para Cavalcante na terça e volta na quarta, vai na sexta e volta no sábado. 
A falta de energia é outro motivo de grande tristeza para os Kalunga. São cerca de 470 famílias sem energia elétrica.

As crianças tem escola de ensino fundamental dentro do território. Há transporte escolar dentro do Vão para as crianças, mas quando chove, não podem ir para escola, por causa dos córregos. Por falta de pontes, as crianças precisam andar para pegar o transporte. Tem criança que anda $3 \mathrm{~km}$ para ir para a escola. Ela diz que, mesmo com as dificuldades, todas as crianças do Vão frequentam a escola, primeiro por que os pais não querem perder o Bolsa Família, segundo, por causa da merenda escolar.

Quando os filhos vão para o ensino médio, precisam ir para Cavalcante. Aí começa outro problema, onde as crianças ficam? Muitas meninas vão trabalhar em casa de família para ter onde morar e poder estudar. Outros ficam em casa de parentes que já estão lá. Daí de Cavalcante, os jovens vão para Brasília e Goiânia, e não voltam mais.

Mas, Dona Aimiram disse que melhorou muito. Há dez anos as mulheres tinha que subir a serra de pé para pegar o caminhão para ir na cidade parir. Hoje, o agente de saúde liga para a ambulância da cidade ir buscar as mulheres quando chega sua hora.

Outra coisa é a renda do Bolsa Família, que é a única em muitas famílias. A outra renda da maioria das famílias do Vão, segundo Dona Aimiram, é a aposentadoria, pois os moradores do Vão são em sua maioria idosos, já que os jovens vão embora.

Os cinco filhos de Dona Aimiram estão fora do território. Dois de seus filhos estão fazendo faculdade, uma está cursando licenciatura na UNB e outro administração. Os outros estão trabalhando.

A renda da família de Dona Aimiran é do trabalho dela e de seu marido fora do território. Ela passa algumas temporadas fora para trabalhar na construção civil. Ela aprendeu o trabalho da construção civil quando houve o programa de habitação e ela foi contratada para cozinhar. O programa incentivou as mulheres a aprender a rejuntar. Ela diz que das mulheres ali do Vão somente ela aprendeu. Ouve a proposta de colocar o curso do Pronatec de construção para 
mulheres, mas não houve demanda. Cinco cursos foram oferecidos pelo Pronatec em 2014, mas foram principalmente na área do turismo.

Ela não é beneficiária do Bolsa, pois recebe pensão (não ficou claro que pensão é essa). Ela também planta roça e produz farinha. Ela fala com muito orgulho da farinha Kalunga. Eles levam sua produção de farinha para a cidade para vender nos mercados e para as pessoas na rua.

Quando estávamos conversando, e almoçando, o marido de Dona Aimiram chegou em uma moto. Quando viu Beto, deu uma gargalhada e disse "Eh Beto já chega comendo?" Tive a certeza que Beto realmente era de casa.

O Marido de Aimiram, Seu Manoel, é do Ceará e a conheceu em Brasília. Mora no Vão do Moleque há dois anos com ela. Disse com muito orgulho que agora é Kalunga, que não abre mão de ser Kalunga e de morar ali. Apesar de ter de sair de lá para trabalhar em obras por empreitada em Brasília ou Formosa, ele sempre volta para sua casa no Vão. Quando conversamos sobre a dificuldade de migrar frequentemente para trabalhar, novamente o assunto foi a estrada. A estrada impede que eles consigam sobreviver em sua próprias terras.

Eles relaram uma reunião que fizeram na Capela pela Associação Kalunga para juntar dinheiro para pagar as horas do trator para arrumar a estrada em 2014 para preparar para a festa do Vão, que ocorre em setembro. Porém eles ainda estão devendo recurso. Eles esperam arrecadar recurso pela Associação. Parte do dinheiro da portaria do Engenho vai para a associação, que deve ajudar a cobrir o dinheiro que eles ainda devem do trator.

Como a estrada novamente está ruim, eles vão novamente reunir para consertar. Eles vão consertar com as próprias mãos se não conseguirem dinheiro para passar o trator novamente. Dona Aimiram irá ficar responsável por cozinhar junto com outras mulheres, e os homens vão consertar. Eles pretendem filmar e colocar na rede social a fim de chamar atenção para a sua triste realidade.

A falta de interesse do governo local em desenvolver o território Kalunga foi longamente falado. Segundo eles, o prefeito só aparece nas festas e na época de eleição. 
Mas os Kalunga tem grande motivação para participar e lutar pelo desenvolvimento. Eles relataram terem ido na posse da Presidente Dilma e que levaram suas principais reinvindicações: água, estrada e energia. Mas disseram que sabe que tudo que vai do Governo Federal tem que passar pelo prefeito. Por isso, eles não tem esperança de que o recurso vai chegar até o sítio Kalunga.

Dona Aimiram e Seu Manoel sabem da potencialidade de seu território para o turismo. Fosse a estrada melhor, eles acreditam que seria possível tirar renda do turismo e da agricultura. Eles plantaram muito, aderiram ao PAA, mas não tem como entregar os produtos, por falta de transporte, já que ninguém tem carro por falta de estrada. Eles sabem o quanto o cerrado é rico e que poderiam também tirar renda do extrativismo do cerrado, mas se sentem impotentes perante à falta de mobilidade.

Ainda, os jovens iriam ficar lá. Esse é um dos sonhos de Dona Aimiram. Ela sabe que "jovem não fica em lugar que não tem desenvolvimento por que os jovens gosta das moda, gosta de ter um carro..."

O orgulho de ser Kalunga de Dona Aimiram e Seu Manoel pode ser facilmente percebido, pois eles falaram com muita empolgação de suas festas religiosas, de suas danças. Seu Manoel disse que é susseiro, ao que Dona Aimiram dá uma grande gargalhada, pois ela diz que ele quer ser um deles de qualquer jeito. Ela me mostra as roupas dela de dançar sussa com muito orgulho. Fala de todas as grandes susseiras e das apresentações que fazem nas festas ali e fora dali.

A hospitalidade de Dona Aimiram foi incrível, ao final ela armou uma rede para eu deitar e descansar. Apanhou um monte de pimenta e uma abobora para eu levar para casa e ainda insistiu que eu fosse banhar no rio perto de sua casa. Devido à estrada, eu só pude aproveitar a pimenta e a abobora. Não podia perder tempo, pois sabia que ainda tinha que conversar com Seu Mochila e tinha que sair de lá no máximo 17h se eu não quisesse acampar lá, por que se durante o dia era difícil passar, de noite eu não queria nem ver. E sinal de celular só pega em um pé de coco na beira da estrada na serra. E não é todo celular, disse eles. 


\section{VÃO DO MOLEQUE, CONVERSA COM SEU MOCHILA- JOAQUIM MOREIRA DA SILVA, 70 ANOS, 10 FILHOS COM DONA IVA, DESSES SOMENTE DOIS ESTÃO MORANDO NO TERRITÓRIO KALUNGA}

A ida da casa de Dona Aimiram para o Seu Mochila foi bem interessante. Primeiro, passamos pela Capela do Vão do Moleque onde há uma igreja, duas escolas, a antiga e a nova, e uma série de cabanas de palhas, que são utilizadas nas épocas de festa.

O lugar é lindo, pois fica no Vão das Serras, de onde se avista uma cachoeira caindo ao longe, provavelmente por que é época das águas. Não há energia, não há água, e nem gente por perto. Mas pude imaginar a alegria que é na época das festas, quando os Kalunga de todos os povoados migram para aquele lugar, morando temporariamente em suas cabanas de palha- há mais de 200 lá escondidas nos matos.

Depois seguimos para a casa de Seu Mochila, Pegamos alguns caminhos que não são estradas, são mais trilhas abertas no meio do mato. Porém, são muitas trilhas abertas e acabamos no perdendo. Beto achou que teríamos que atravessar um córrego barrento, que não seria necessário se não tivéssemos nos perdido, para ir à casa de Seu Mochila. Mas aí o carro ficou. Atolou. Quanto mais Beto tentava acelerar mais o carro afundava. Ficou nervoso e saiu do carro. Eu mantive a calma, pois sabia que ele estava nervoso por que estava preocupado com minha opinião. Ele saiu andando pela estrada a procura de uma caminhonete que tínhamos visto pouco tempo antes chegando em uma das casas para instalar a cisterna de captação de água de chuva.

Dentro do azar, demos sorte. A caminhonete estava próxima e Beto conseguiu que eles fossem até nosso carro para puxá-lo. Mesmo estando em uma caminhonete 4x4, eles disseram que também haviam atolado ali naquele mesmo lugar no dia anterior. Pensei comigo que as pessoas depois daquele córrego estavam ilhadas então. Entendi o que Dona Aimiram dizia. Não há pontes em córrego nenhum. Nem mesmo pontes de madeira como costuma-se ver nos meios rurais.

Após o carro sair do atoleiro, demos meia volta e voltamos para procurar a casa de Seu Mochila. Duas mulheres carregando baldes de água na cabeça andavam na beira da estrada. Apesar do peso da água na cabeça, andavam sorridentes em suas roupas coloridas. Estavam 
vindo do córrego onde atolamos. Elas informaram o caminho que devíamos pegar. Estávamos tão perto que chegamos em menos de 5 minutos.

Ao chegarmos na casa de Seu Mochila, mais uma vez testemunho a popularidade de Beto com os Kalunga, ao sermos recebido com toda alegria por Seu Mochila, que também reclama de não saber que íamos por que poderíamos ter ido almoçar com ele. Seu Mochila, que mora em uma casa também de concreto e telha do programa de habitação, estava feliz pois sua cisterna tinha acabado de ser entregue, apesar de não ter sido instalada ainda.

Com muitas galinhas no quintal e fogão à lenha do lado de fora da casa, a casa de Seu Mochila tinha a grande vantagem de estar a menos de $100 \mathrm{~m}$ do córrego. Por conta própria, Seu Mochila comprou uma placa solar para gerar energia e colocou uma bomba que joga água para casa. Assim, ele tem água na torneira da pia, onde Dona Iva, sua esposa, lavava a louça. Mas a água dura somente até junho. Depois o córrego seca. A água fica pouca, os animais morrem, são jogados no córrego, e eles bebem “essa água cheia de doença". Ele fala longamente da necessidade de se ter água boa de beber. A água que eles bebem na época da seca é somente por causa da necessidade de sede, mas é “água de doença”, ele diz.

Como Seu Mochila e Dona Iva são aposentados, a renda deles permite que eles consigam fazer alguns investimentos para melhorar sua qualidade de vida. Além da placa solar, Seu Mochila e Dona Iva também compraram uma antena para celular por R\$1.300,00. Mas não é sempre que consegue pegar. O melhor lugar, segundo ele, repetindo Seu Manoel, é o pé de coco lá na serra. Falou que enquanto não colocarem uma torre no alto da serra, o problema de comunicação ali permanecerá. Não há muito que eles possam fazer por conta própria.

Outro investimento que Seu Mochila fez foi na cisterna calçadão para captar água de chuva para a produção e seus animais. Gastou $\mathrm{R} \$ 1.200,00$ em cimento e construiu da maneira que achou que era. Porém, por falta de conhecimento da tecnologia de construção da cisterna, Seu Mochila viu sua cisterna desabar e seu rico dinheiro ir embora na primeira chuva que deu.

Ele me mostrou todos esses investimentos em sua terra com muito orgulho, mas quando pedi a ele para conversar para o fim de uma pesquisa, ele logo reagiu dizendo que não gostava de pesquisador. Não sei o motivo. Mas Beto logo me salvou. "Mas ela aqui trabalha no Ministério que tem o programa de Cisternas, ela entende de política pública. E aí? Gostou 
dela?" Ele abriu um sorriso para mim e disse "aí eu gostei. Eu gosto de conversar com gente que sabe das coisas". Mas logo tratei de falar a ele que eu não estava ali em nome do Ministério, e sim por causa da minha pesquisa na Universidade. Ele então diz, "é mas como você trabalha lá no Ministério, quem sabe cê fala para eles lá como é que a gente vive aqui”. Senti o peso nas costas ao ver a esperança depositada em mim.

Antes de começarmos a conversar, pedi a Seu Mochila permissão para gravar e para tirar um foto dele. Ele pediu que eu aguardasse. Entrou em sua casa e colocou sua camisa de guia Kalunga. Uma camisa verde muito bonita com o nome QUILOMBO KALUNGA estampado. Muito orgulhoso de sua origem, Seu Mochila faz pose e deixa que eu o fotografe com sua camiseta.

Aproveitando sua ida dentro de casa, Seu Mochila me trouxe uma revista de 2008 em que ele aparece junto com Seu Sirilo na cerimônia de criação do Comitê Gestor das Comunidades Remanescentes de quilombos do Estado de Goiás. A reportagem da revista dizia que uma das grandes conquistas tinha sido a liberação pela Secretaria Estadual de Meio Ambiente e Recursos Hídricos -SEMARH para a construção de rodovias, obras de saneamento básico e eletrificação em meio rural no município de Cavalcante, que, segundo a revista, era uma demanda das populações quilombolas. Seu Mochila me mostra a reportagem com um pouco de cansaço e pergunta: "Será que vai chegar enquanto eu ainda estou vivo? As coisas tem que ser mais rápidas para eu poder ver."

Dona Iva fica olhando atentamente outro livro que ele trouxe sobre o Quilombo Kalunga, um livro muito bonito com fotos das paisagens e dos Kalunga, feito pela Secretaria de Turismo do Goiás. Eu olho para ela e digo: "Seu lugar é muito bonito". Ela sorri, mas não é de falar de muito, apenas me mostra outras fotos do livro, como quem diz "tem muito ainda que você não viu".

Pergunto para Seu Mochila se a vida melhorou depois que o território deles foi reconhecido como quilombola. Ele fala que melhorou muito por que as pessoas lá tem uma renda garantida como o bolsa família e aposentadoria. Porém, faltam estrada, energia elétrica, e, principalmente, posto de saúde. São quase 500 famílias desamparadas pelo Estado. 
Ele destaca que no Engenho, onde somente há cerca de 100 famílias, "tem tudo, mas é por que eles são unidos". Ele fala da importância de ter união entre os Kalunga do Vão do Moleque para que eles possam reivindicar e lutar pelos seus direitos. "A união é que faz a força e a força traz união".

Ele diz que vai fazer um ofício para pedir ajuda para construção da estrada. Ele acredita que uma deputada que eles ajudaram a eleger poderá ajudar nessa empreitada. "Eu tenho amor na minha comunidade, e quando eu falo com um órgão e ele diz que vai arrumar, eu pergunto 'é antes deu morrer?', eu falo brincando mas é sério, já esperamos muito”.

Ele conta que sua mulher foi parteira, e que ajudou muita mulher a dar a luz e que nenhuma morreu. Hoje ela não faz mais isso por que falam que a mulher tem que ter filho no hospital. Mas aí as mulheres ficam esperando o carro vir e muitas já morreram por falta de socorro. A estrada não deixa carros comuns passarem.

Hoje ele liga lá na cidade para pedir ajuda de ambulância quando alguém precisa, por que ele comprou sua antena de celular, mas quando a antena vira ninguém consegue falar, "aí morre mesmo sem socorro".

"Se melhorar a situação de nós, nós não precisa de cidade", diz Seu Mochila. Ele tem toda disposição para lutar pelo desenvolvimento de sua comunidade. Mas não sente que tem o apoio do governo local, pois as demandas do Vão do Moleque nunca são ouvidas. Ele diz que "votaram em um prefeito que não é da região, e quem votou e quem não votou tá mundo perdido, ele nem olha para a Comunidade Kalunga”.

Mas Seu Mochila tem confiança na sua identidade e na força que as comunidades quilombolas ganharam nos últimos anos. "A Comunidade Kalunga é uma comunidade forte. Eu perdi as vistas (por causa de uma Catarata) e por que eu sou Kalunga eu fui o primeiro a ser atendido no Hospital de Base de Brasília. Agora eu tô enxergando.”

Ele disse que gostava de conversar comigo por que eu olhava dentro do olho dele, que eu mostrava que estava entendendo o que ele falava. Então me pergunta se tem jeito de melhorar a vida deles. Eu disse que políticas públicas para tudo isso que ele tinha me falado existiam. Precisava levar para lá. 
Seu Mochila diz que muita coisa começou a melhorar, mas que precisam demais de que as políticas cheguem lá no Vão do Moleque. Fala de seu esforço para lutar pelos direitos de sua comunidade, "Eu sou um besta, mas é aquele besta esforçado".

Fala da construção das 60 casas no Vão do Moleque e de como eles ajudaram na construção. Mas ficaram faltando mais de 120, por problemas na FUBRA. Ele diz que tem o nome de todas as famílias que ainda moram em casa de palha e que pode fazer um ofício para levar para as autoridades para continuar a construção que não foi finalizada.

Ele sugere que para as casas que não foram construídas, cada morador compra 4 telhas de $16 \times 16$, que custa $R \$ 320,00$, segundo estimativa dele, para fazer uma varanda e colocar a calha para receber a cisterna. "A água é para todos, o Governo Federal tá dando é para melhorar a situação dos Kalunga”. Seu Mochila não se conforma de o Programa da Cisterna não chegar em todas as casas.

Eles plantam arroz, mas precisam levar para beneficiar em Cavalcante, pois eles ganharam uma máquina de beneficiamento de arroz, mas fica na Associação na cidade.

Fala da importância de se ter uma escola agrícola dentro do Vão, pois os jovens todos saem da comunidade para a Brasília ou Goiânia, e não voltam, o que muito entristece os pais que ficam. Ele diz que seus filhos trabalham na cidade, mas moram lá no Vão, pois estão em casa alugada na cidade. Isso não é morar.

Dona Iva nesse momento interrompe seu silêncio e diz que os jovens vão por que querem aprender, observar alguma coisa. Mas Seu Mochila diz que acha que eles não estão indo para frente em Brasília, pois eles ganham um salario lá, e eles poderiam estar dentro do território trabalhando e ganhando mais como professor, enfermeiro, por exemplo. "Se for indo, e nós não achar uma categoria e eles não voltarem para cá, não vai sobrar ninguém aqui. Por que vamos todos morrer." Ele faz as contas e diz que de 10 que sair, 5 voltar, já será suficiente. "Os jovens que se formam tem que voltar para trabalhar pela melhoria de sua comunidade", pensa Seu Mochila. "Eles tem que aprender a ganhar dinheiro no lugar deles". 
Seu Mochila também acredita que o turismo pode vir a ser uma fonte de recurso para eles, inclusive fez um curso de guia de turismo ofertado na semana anterior. Foram 68 alunos, 5 do Vão do Moleque, 6 do Vão de Almas e o restante do Engenho. Entristeceu Seu Mochila o fato de os Kalunga do Vão terem tido tão pouca participação no curso. Mas a motivação para fazer o curso ainda é baixa para aqueles que estão isolados ali no Vão, já que a estrada não deixa que os turistas cheguem até ali. No entanto, Seu Mochila não se conforma pois sabe de todo o potencial de exploração turística existente ali, falando com muita propriedade o que o turista gosta. Ela sabe que o cerrado preservado, os vãos de serra, as rochas, os rios e sua cultura são atrativos para aqueles que moram na cidade e querem contato com a natureza.

"Esse lugar aqui é um lugar muito ótimo para nós. Nascemos e criamos aqui nessa terra. Nós tem amor por ela. Meu bisavô morreu nela, meu avô morreu nela, meu pai morreu nela e eu vou morrer nela. E eu queria largar para meus filhos. Essa terra é uma terra amada por Deus. Só larga ela quem não tem bondade."

Seu Mochila tem consciência que a permanência do povo Kalunga ali no território quilombola é condição para a formação do espaço Kalunga. Sem o homem, sobra apenas a terra. Se eles não mais estiverem ali dentro de alguns anos, ou mesmo se eles forem poucos, a terra ficará à disposição para exploração pela mineração. Assim me disseram pessoas que tem ligação com o governo local. Segundo essas pessoas, a gestão local quer que os Kalunga saiam de lá para poder explorar manganês e ouro. Isso justifica a tão falada falta de interesse da prefeitura em apoiar e levar as políticas públicas para o território Kalunga.

\section{VÃO DE ALMAS, 11 DE MARÇO DE 2015}

\section{VÃo de ALMAS, CONVERSA COM SEU ZEZINHO, 45 ANOS, E DONA TITINHA, 40 ANOS, 6 FILHOS}

A segunda viagem ao território Kalunga teve a intenção de ir ao Vão de Almas, completando as comunidades Kalunga do município de Cavalcante, onde está inserida a maior parte do território Kalunga. Mais uma vez, meu companheiro de campo foi o guia Beto Baiano, devido ao seu conhecimento não só do território como das pessoas que ali habitam. O caminho desta vez foi imensamente mais fácil do que o do Vão do Moleque. Passa-se por Teresina de Goiás, pela comunidade Kalunga da Ema, e depois de descer a longa serra do pouso do padre, que, 
apesar de íngreme, estava bem transitável, com algumas pontes de passagem e poucos córregos para se atravessar, nenhum com o nível de dificuldade encontrado no Vão do Moleque. Talvez por isso, a estrada não foi o principal ponto da conversa com os moradores do Vão de Almas com foi com os do Vão do Moleque.

Foram somente duas horas de viagem de Cavalcante ao Vão de Almas, isso por que houve paradas para fotos. Ao passarmos pela comunidade Kalunga da Ema, no município de Teresina, vimos as casas do programas de habitação do Governo- todas de concreto com telhas de cerâmica, caixas d'água e ligação de energia elétrica, em um povoado mais concentrado.

Ao chegarmos ao Vão, não mais vemos as casas de concreto. As casas, bem mais distantes umas das outras, como no Vão do Moleque, são de adobe e telhados de palha. Passamos por uma escola, onde havia somente um cômodo de adobe e palha com algumas carteiras empilhadas sobre as outras. Meu coração partiu de saber que crianças estudavam ali. Claro que o quintal do intervalo era um imenso verde, ao ar livre, mas nenhum parquinho como visto no Engenho, ou nenhum lugar para refeições. Era somente uma sala de aula no meio do mato.

Andamos mais um pouco e chegamos à casa de Seu Zezinho, que havia sido avisado que chegaríamos para almoçar. Beto me informou que, como seu Zezinho mora em península entre o Rio das Almas e o Rio Paranã, ele possui um barco de motor que usa para fazer passeios de barco com turistas e/ou atravessar as pessoas para o outro lado do Rio Paranã. Assim, ele e sua esposa fornecem uma espécie de cama e café para turistas. Neste caso, Dona Titinha cozinha café, almoço e janta ( a $R$ \$ 25 por refeição), e eles fornecem um rancho para as pessoas acamparem, cobrando $\mathrm{R} \$ 10,00$ por barraca. Inclusive, Seu Zezinho construiu um cômodo de concreto para algum turista que não levar barraca poder dormir.

A casa de Seu Zezinho e Dona Titinha possui chão de areia solta, paredes de adobe, telhado de palha e poucos cômodos, e quase nenhum móvel. São três construções, a primeira, onde há uma sala e dois quartos, onde dormem o casal, e o outro onde dormem os quatro filhos. Anexa está cozinha, com o fogão a lenha, um mesa pequena simples de madeira, um banco, dois filtros, e baldes de água. Ainda, há um outro rancho com uma geladeira não ligada, já que não 
há energia elétrica, uma grande mesa de madeira com cadeiras de plástico, onde eles fornecem a alimentação para os turistas, onde nós comemos.

Os filhos estavam todos em casa, pois já haviam chegado da escola, que fica longe de sua casa. Não era a escola que havíamos visto no caminho, e sim uma outra que ficava a cerca de 1 h30 caminhando ou 30 minutos de bicicleta. Porém somente há duas bicicletas na casa para os quatro filhos e vão dois em casa bicicleta.

São dois filhos adolescentes de 15 e 16 anos e outros duas crianças de 12 e 9 anos. Seus outros dois filhos maiores estão em Brasília trabalhando. A filha, hoje com 22 anos, casou-se aos 17 anos e mudou-se com marido. O filho, hoje com 23 ainda não se casou, mas teve que se mudar para arrumar um emprego, pois ali, segundo Titina, eles não tem opção de trabalho ou de seguir com os estudos. Ambos pararam de estudar no $9^{\circ}$ ano, pois este é o máximo que se pode estudar dentro do Vão de Almas.

Dona Titinha e Seu Zezinho já estão preocupados com os dois filhos de 15 e 16 anos, que estando no $9^{\circ}$ ano, terão que se mudar no próximo ano. Eles não tem onde morar na cidade de Cavalcante para cursar o ensino médio. Seu Zezinho não gostaria que sua filha se casasse somente para sair de casa e ir trabalhar, gostaria que ela seguisse com seus estudos, e deseja o mesmo para seu filho. Dona Titinha vê a possibilidade de sua filha ir trabalhar em uma casa de família onde ela pudesse morar e trabalhar, mas não sabe como seu filho faria. Seu Zezinho acha que o destino de sua filha é se casa cedo, pois é muito difícil para eles sustentarem os filhos na cidade para estudar.

"Elas tem vontade de estudar, mas terminou o estudo (no $9^{\circ}$ ano) e fica aí fazendo o que. Então elas tem que arrumar um marido para sair de casa e trabalhar.”( Seu Zezinho)

Titinha diz que apesar da saudade que sente das crianças, elas gostariam que seus filhos que hoje tem 14 e 15 anos saíssem para estudar o ensino médio.

"Eu queria que eles estudassem para ter um emprego bom. Tem que arrumar uma casa de uma pessoa que eles fica e trabalha e já estuda. Para as meninas é mais fácil, mas para os meninos é mais difícil, pois eles não tem como arrumar emprego nas casas. “ 
A falta do ensino médio dentro do território expulsa os jovens Kalunga de seu território. Após saírem para buscar emprego e estudos, encontram uma vida na cidade, que apesar de menos generosa com seus habitantes em termos de beleza natural e vida saudável, apresenta um estilo de vida com um mínimo de infraestrutura possibilitadora de maior liberdade com energia elétrica e agua encanada.

Zezinho acredita que a titulação da terra não trouxe benefícios, pois não chegou o benefício prometido. "Se vendesse uns 3 alqueires, a gente podia comprar um lote na cidade para por os meninos para estudar, para comprar uma placa solar". Quando perguntei a ele se não seria ruim a presença de pessoas de fora, que não são Kalunga, no território, caso ele vendesse, ele disse que não. "Ia era ajudar a gente, por que podia contratar a gente para trabalhar. Aqui é todo mundo pobre."

Dona Titinha e Seu Zezinho gostariam de sair do Vão de Almas por causa das dificuldades sofridas pela falta da presença do Estado. Mas se tivesse energia elétrica, agua na porta de casa ("não precisa nem ser dentro", diz eles) e banheiro com vaso e chuveiro, Dona Titinha e Seu Zezinho dizem que não sairiam nunca de sua terra.

"Aqui significa o começo da minha vida. Agente criou amor no lugar, mas a gente tinha vontade de viver num lugar melhor. De ter uma casa boa. [...] aqui que tem estudo sai, só tá ficando quem não tem estudo, por que não tem para onde ir [...] Mas se por energia aqui eu não quero sair. A gente tem vontade de ir para a cidade por causa da energia. Se por energia eu não quero sair".

"Com a energia, a gente pode comprar uma geladeira, guardar as coisas na geladeira para não perder" "A gente puxa uma agua do rio, faz uma horta aí e tem verdura o tempo todo, não precisa comprar na cidade". (Titinha)

"Meu maior sonho é ter energia e uma casa boa com água, banheiro, água quente e uma horta" (Titinha). Quando diz isso, ela até suspira.

Ela fala sobre a comunidade da Ema que fica do outro lado rio e tem energia, casa, banheiro. "Todo mundo tem banheiro lá" 
Dona Titinha precisa ir até o rio, que fica perto de sua casa, cerca de 6 vezes ao dia buscar água para sua família. Por causa disso, tem dores fortes nas costas e pescoço diariamente. Lava roupa e louças e toma banho no rio. Não há banheiro dentro ou fora da casa. Eles precisam usar o mato, faça chuva ou faça sol.

Seu Zezinho também pensa na energia elétrica como a principal condição de geração de oportunidades para ele e sua família. Se tivesse energia, ele poderia comprar uma bomba para puxar água do rio para que sua família tivesse água na porta de casa e poderia puxar água também para irrigar um horta. Ele fala da dificuldade de se fazer hortas ou outro cultivo mais perene devido aos longos períodos de seca.

Ele já comprou uns 4 motores a diesel para puxar água do rio mas todos pifam. Ele também já comprou gerador para ter luz, mas passou uns 6 meses e pifou. "Uma hora a energia elétrica chega né”.

A produção agrícola de Seu Zezinho da maior parte dos Kalunga do Vão de Almas é a mandioca. Mas também produzem arroz, milho, feijão e abóbora. Porém os últimos apenas para sobrevivência de suas famílias e animais. Da mandioca, eles produzem farinha e tentam vender nos mercados da cidade por $\mathrm{R} \$ 3$ a $\mathrm{R} \$ 5$ por quilo na cidade. No entanto, como todos produzem mandioca e fazem farinha, a oferta acaba ficando maior que a demanda e pouco lucro se consegue.

Precisam comprar óleo, açúcar, café, sabão, e outros itens. O sabão antes era feito de tiguim fruta do mato que parece um coquinho, mas seu Zezinho diz que hoje o povo acha mais fácil comprar, quase ninguém mais faz o sabão. Mas eles só conseguem vender a farinha.

Seu Zezinho também produz gergelim para vender para um "homem de São Paulo" a R\$ 7 por quilo. Ele diz que em 2014 até arrecadou um bom dinheiro com o gergelim (mas não disse quanto). Este homem compra tudo que eles produzirem, mas as chuvas foram poucas em 2014 e eles acabaram perdendo grande parte da produção.

Seu Zezinho também faz extrativismo de sementes do cerrado. Em 2014 arrecadou R \$ 4 mil com a venda das sementes para uma ONG. 
Ele diz que algumas pessoas conseguem vender bolo, massa de tapioca para as escolas, mas é muita gente vendendo e pouca escola para receber. Pelo que ele disse, é uma venda feita diretamente na escola. Não é o Programa de Aquisição de Alimentos para merenda escolar.

Eles não tem conhecimento sobre o Programa Cisternas, sobre o Programa de Aquisição de Alimentos, Fomento, Assistência Técnica Rural, ou qualquer outro programa de Segurança Alimentar. Seu Zezinho, com sua inteligência, inclusive sugeriu que o Governo comprasse a produção deles e entregasse para os hospitais, para pessoas que precisam, escolas... Quando eu disse a ele que este programa existia, que se chamava Programa de Aquisição de Alimentos, seus olhos vibraram.

Ele não conseguia acreditar que o Governo comprava alimentos de pequenos produtores e que eles não sabiam disso. Nem eu conseguia acreditar no quão mal o Governo tem se comunicado e na falta de vontade da governo local para levar não só as políticas, mas também as informações.

"Se fosse uma prefeitura que quisesse ajudar a comunidade e comprasse os alimentos da gente, a gente podia até comprar uma placa solar, puxar uma água [...]”

A única renda segura e certa da família é o benefício do Programa Bolsa Família. Segundo Seu Zezinho é a única política pública que eles viram chegar no Vão de Almas. "Esse é garantido", diz ele. O Bolsa Família, apesar de ser um benefício de baixo de valor- a família de Seu Zezinho e Dona Titinha recebe apenas R\$ 170,00 mensalmente, é o recurso que permite que eles se programem.

Antes do Bolsa Família, o dinheiro era só "de relar mandioca para vender farinha". Muitas vezes não conseguiam vender a farinha. E ficavam sem dinheiro nenhum.

O dinheiro do Bolsa Família é utilizado principalmente para comprar chinelo para as crianças ir para a escola e cadernos. Quase não sobra para comprar alimento. "É pouco mas tá bom. O ruim é nada". 
Porém, seu Zezinho ganha R 170 de Bolsa Família e gasta R \$ 50 de passagem. Ele diz que ainda precisa dormir lá na cidade por que o transporte vai em um dia e só volta no outro. $\mathrm{O}$ hotel é R\$ 40 para solteiro. "Quando não tem nenhum amigo na cidade, eu tenho que ficar no hotel”. Então quando ele precisa pagar hotel, somente sobra R\$ 80. Titinha diz que o dinheiro "nunca sobrou para comprar umas coisa assim que tinha vontade. Coisas assim de casa mesmo que mulher gosta: um armário para por as roupas ou um colchão.”

Ela diz que "é pouco, mas já ajuda demais todo mundo". Ninguém mais passa fome no Vão de Almas. O pouco recurso permite que eles façam as compras de alimentos, mesmo que pouca, quando é tempo de estiagem e eles não conseguem tirar o sustento de sua terra.

Seu Zezinho e Dona Titinha nunca ouviram falar do CRAS- Centro de Referência da Assistência Social. Somente conhecem a Secretaria da Igualdade Racial. Somente recebem visitas do Agente Comunitário de Saúde, que vai lá uma vez por ano para medir e pesar as crianças, por causa da condicionalidade de saúde do Programa Bolsa Família.

Quando precisam de assistência médica, apesar de nunca terem precisado, segundo eles, devem ir ao posto em Cavalcante. Não fazem exames ou consultas de rotina. Mas como Seu Zezinho possui um telefone celular rural, e é um dos únicos ali no Vão, ele sempre chama a ambulância quando alguém precisa ser socorrido. E, segundo ele, o carro demora, mas chega. Dona Titinha diz que melhorou muito, pois antes da estrada, construída há apenas 5 anos, eles precisavam colocar as pessoas em uma rede e ir carregando em um burro ou andando até a cidade. Ela lembra que muitos chegaram a morrer no caminho. Eu não conseguia acreditar que uma mulher com apenas 40 anos tivesse memória de uma situação de precariedade dessa.

Quando os filhos ficam doente, Titinha e Seu Zezinho tratam com remédio caseiro feito de ervas. "Eu sou remedeiro. Eu conheço todas as ervas boa do mato: Raiz de aça peixe e folha de laranja são bons para febre. Mas não pode por açúcar, se não é chá, não é remédio.”

Dona Titinha, mais calada, quase não sai de casa, pois o caminhão é caro, são $\mathrm{R} \$ 50,00$ para ir e voltar de Cavalcante. Ela diz não ter para onde ir. Sua vida é ficar ali buscando água, cozinhando dia e noite para sua família, esperando um dia sair do escuro. 
Seu Zezinho é bastante comunicativo. Seu Zezinho só vai à cidade para sacar o Bolsa Família e quando tem reunião da Associação Quilombo Kalunga. Ele diz que no Vão de Almas cerca de 8 pessoas frequentam a reunião regularmente. O presidente da AQK, Vilmar, foi eleito em 2015 para um mandato de dois anos, podendo ser eleito por mais dois.

Zezinho reclama que a Associação não investe recurso no Vão de Almas. O recurso da portaria do Engenho II, na opinião dele deveria ser utilizado para encanar água para as casas do Vão, "para ajudar o povo". Ele reclama que os turistas banham nas aguas do Rio Capivara lá no Engenho e o Rio chega poluído lá para eles.

Eles votaram para o prefeito eleito. A votação ocorre nas escolas dentro da comunidade. Eles disseram que o prefeito prometeu colocar energia elétrica no lugar do festejo. Mas nem na escola foi colocada.

Ele diz que tem um vereador Kalunga, Salviano, que consegue de 15 em 15 dias um caminhão para levar o povo do Vão de Almas para cidade. "É a única coisa que sei que ele faz". "Aqui tá uma coisa muito difícil. O pessoal tomou medo dos outros. Muita gente entrou aqui prometendo coisas, pegando assinatura dos Kalunga e ficou rico moiando a mão no dinheiro de projeto usando o nome dos Kalunga". "Tem muita verba aqui pro Goiás mas aqui num chega".

No mês de janeiro de 2015 vieram uns juízes e uns promotores e fizeram uma audiência no Vão de Almas e verificaram o que eles estão precisando, como a energia. Prometeram que iam tomar providencia. Mas Seu Zezinho parece estar desacreditado do poder público local.

Não entende para onde vai o dinheiro do Governo Federal que sai para os Kalunga. É interessante notar sua crença no Governo Federal, pois ele acredita que o Governo Federal acha que eles já tem energia elétrica, por isso não fazem nada. Ele diz que o Governo Federal já mandou esse dinheiro, mas que a prefeitura "deu sumiço". "Para onde foi o dinheiro? Ninguém sabe. A gente só sabe que o povo da prefeitura vai ficando rico.” Seu Zezinho diz que o Governo Federal deveria acabar com as prefeituras e criar uma instituição que atendesse as famílias, que conhecesse os problemas que as comunidades passam. Eu disse que este era o papel das prefeituras. "É, não é?”, disse ele incrédulo. 
“As promessa é demais. Não adianta ter prefeitura na cidade se não ajudar o município, o povo. Prefeitura para meu entendimento era para ajudar as comunidade: com escola boa, com agua para as crianças não beber agua poluída. Olha a agua do Paranã agora procê ver a agua que as crianças bebe, só tem barro. [...] a barriga deles tem mais é verme.”

Expliquei para seu Zezinho sobre o programa Cisternas. Ele ouviu atentamente e achou incrível, mas ao final ele concluiu sem fé "Programa es (o Governo Federal) tem né, mas num vem pra cá."(...) "Se tivesse jeito de trazer manilha prá cá, eu mesmo fazia uma cisterna no chão."

Seu Zezinho acredita que se tivesse melhor estrutura no Vão de Almas, eles poderiam gerar renda por meio do Turismo, assim como a comunidade do Engenho II. Ele inclusive fez uns cartões de guia turístico para divulgar seu trabalho. Ele faz passeio de barco. Mas não tem um fluxo de turistas frequente ainda. Ele diz que às vezes demora até 3 meses sem ninguém ir lá.

Seu Zezinho saiu para atender o telefone, pela segunda vez. Parecia alguém do Engenho, que o chamava para alguma reunião. Ele ficou bastante tempo no telefone. Eu desliguei o gravador para o aguardar. Mas eu e Dona Titinha nos distraímos conversando sobre suas vontades difíceis de satisfazer, como ter um creme de corpo, um shampoo, um condicionador. Coisas que ela, como toda mulher valoriza, mas que a pobreza e o distanciamento do Estado e do desenvolvimento a restringem.

\section{VÃO DE ALMAS- CONVERSA COM DONA EVA, 75 ANOS, 12 FILHOS, SENDO 8 VIVOS.}

Cheguei na casa de Dona Eva no fim da tarde, lá estava uma linda e magra senhora de 75 anos, com catarata nos olhos que a impossibilita de enxergar completamente, tecendo algodão na companhia de três netos, que moram com ela, pois os pais moram na cidade. Ela diz que estava fazendo o tear por que estava descansando enquanto chovia e não podia ir para a roça.

Dona Eva não parou de tecer o algodão para nos receber. Não apresentou muita disposição para conversar no início, mas com o decorrer da conversa, ela se animou, inclusive fez um tour comigo em sua roça de milho, apanhou milho e lima para eu levar para casa e me 
serviu um "remédio", uma espécie de garrafada com cachaça bem forte, que ela faz para tomar todos os dias, dizendo ser o segredo de sua longevidade e disposição para trabalhar.

Dona Eva foi parteira a vida inteira. Segundo seus cálculos, ela já realizou o parto de 271 crianças. Teve uma vida difícil para criar seus filhos na pobreza, na dificuldade de mobilidade até a cidade, na escassez de alimentos, e na ausência de escolas dentro da comunidade.

Considera que "comparado ao que era antes, melhorou muito". Mas falta muita coisa ainda. Em sua opinião, o mais importante seria ter energia elétrica e um posto de saúde dentro da comunidade. Ela já sentiu mal, a ambulância foi buscá-la e ela foi atendida na cidade, mas ela diz que não frequenta posto de saúde por que é muito longe. A primeira vez que ela foi no hospital ela já tinha 70 anos e sentiu uma dor forte e estava com pneumonia.

O segredo de sua saúde está na raizada que ela faz. Ela diz que tem que tomar muito cuidado por que a comida hoje é cheia de veneno.

"Se quiser lumiar é com óleo mesmo, por que não tem energia. O óleo é danado para atacar as vistas d'agente. Mas aqui é assim."

Ela não confiar nos médicos, ela diz que fez um exame para ver se tem carata.

Tem 8 filhos vivos, mas teve 12, dois morreram matados em Teresina e Brasília. Tem 49 netos e 11 bisnetos, que ela acredita vivem melhor que os seus viveram. "Os meninos de hoje não comem mais peixe cozido não comem pirão."

Os seus três netos que moram em sua casa precisam andar até a escola. Só há uma bicicleta. Eles anda mais de uma hora até chegarem na escola.

As crianças, que tem entre 9 e 12 anos, ajudam a avó com a roça depois da escola. Ela planta mandioca e milho e cria galinhas para o sustento seu e de seus netos. Todo o resto da alimentação é comprado na cidade, como por exemplo o arroz e o leite.

Todo mês ela vai até a cidade buscar sua aposentadoria. Mas ela fez um empréstimo para comprar comida e ficou devendo muito, tanto que o dinheiro este mês não dará. $\mathrm{O}$ dinheiro que tem dar comprar "jeito de comer, roupa para os meninos, caderno". Ainda, ela tem que pagar o custo do transporte, que é de $\mathrm{R} \$ 50$ para ir e voltar a Teresina de Goiás no caminhão pau de arara e depois a passagem de ônibus até Campos Belos, onde fica seu Banco.

Ela diz que seus netos não recebem o Bolsa Família. As mães deles também não mandam dinheiro para ajudar no sustento. Assim, Dona Eva passa por dificuldades financeiras para dar conta de sobreviver. 
Mas ela diz que fome ninguém passa, pois todo mundo trabalha na roça, ou recebe o Bolsa Família ou aposentadoria.

Foi parteira, mas hoje ela não faz mais parto por que " as mulheres tão tudo trapalhada". Ela diz que não corre mais o risco de realizar partos, pois hoje as mulheres não tomam mais cuidados durante a gravidez. As mulheres atrapalham o parto por não repousarem na gravidez, segundo ela.

Ela diz que ainda tem muitas parteiras lá. Foi em uma reunião em Brasília, que reuniu parteiras do território Kalunga. Ela diz que ficou sem saber para quê que era. "Era umas palestras. Todo mundo brincando de roda. Batendo nas cadeiras uma das outras”. Ela diz que assinou "um bocado de coisa lá, mas não sei o quê, por que eu não sei ler. Mas eu assinei. Saí assinando." Ela diz que também ganhou um DVD, mas não sabe para quê também pois lá não tem energia: "eu falei que não ia trazer por que não tinha onde por, mas mandaram eu trazer". O que ela gostou mesmo da viagem a Brasília para a reunião de parteiras foi a missa que ela foi.

A casa de Dona Eva está sempre trancada por medo de ser roubada. Ela diz que já houve dois ladrões lá no território. Mesmo com a baixa estatística, ela tem medo de levarem suas coisas, mas ela diz que não é uma sensação de medo, é mais por precaução.

Dona Eva diz que "de primeiro eu tinha marido mas dormia com fome, hoje eu não tenho marido, mas não durmo com fome. Graças a Deus, agradeço a Jesus, melhorou demais depois da aposentadoria." "A minha vida é sofrida demais, só Deus."

Dona Eva relatou que apanhou muito de seu marido, que levava era "peia nas costas" o tempo todo. Ela diz que se fosse hoje "levava ele até a cidade para comprar um café, um arroz, e deixava ele num canto e ia denunciar ele para a Maria da Penha. E lá ele já ficava era preso."

Mesmo com idade avançada Dona Eva busca água no rio e traz "no pote" para abastecer sua casa e aguar sua horta. "Se não tivesse chovendo, nós ia lá no rio procê ver a distancia, é longe".

Dona Eva é muito católica, mas o padre só vai na Igreja do Vão de Almas no mês de agosto, durante a festa. Ela faz suas rezas e faz a festa de São José em todo 19 de março, quando ela faz um "banquete", nas palavras dela, para todo mundo. 


\section{VÃo de ALMAS- CONVERSA COM SEU ALBERTINO, 70 ANOS (1945), 18 FILHOS.}

\section{NASCI E CRIEI AQUI DENTRO}

“É o lugar mais esquecido é o nosso Vão de Almas. Muita gente de fora vem aqui, participa de nós, usa o nome de nós, leva lá pra fora, e nunca que chega nada"

“Aí no barranco rio de lá num tem energia? Lá na Ema? Qual é essa faculidade que tem de lá ter e aqui num tem? Por que que nós aqui num adquiriu um prefeito pra ter dó de nós aqui dentro pro lado de cá?"

"Prefeito só gosta de nós na hora do voto. Votou, virou as costas e babau viola, num olha mais pra trás".

"Essa palavra que eu tô falando a senhora pode levar lá pra fora." Seu Albertino relatou um ocorrido com um jornalista da TV GLOBO que foi ao Vão de Almas gravar uma matéria e levou uma camisa do time do Brasil e perguntei se ele conhecia a camisa. Seu Albertino relatou que foi enfático em dizer que não sabia que camiseta era aquela por que ele não assistia televisão, pois eles não tinham energia elétrica no Vão de Almas.

Então ele diz que depois disso, foi um homem do governo de Goiás e disse que, por causa da reportagem, tinha recebido ordens do Governo Federal de colocar energia elétrica no Vão de Almas:

"A Dilma mandou ele vir aqui me conhecer. Mas nunca chegou. E nós tamo esperando. Nunca chegou. O povo lá de fora gosta de empurrar a gente com a barriga.”

“O prefeito Eduardo foi o único tentou fazer algo por nós aqui, mas o povo não deixou. Ele começou a fazer a estrada. Mas veio aí o cabra chefe do IBAMA e veio aqui para encerrar a estrada. Eu falei a ele: O senhor tem é um coração muito ruim, doutor. Por que nós aqui tá mais é cansado com o coração arrebentado, cansado de carregar gente doente viva na rede para a cidade, mulher nova na hora de ter criança. E ele também não falou mais nada. A estrada tá aí graças ao prefeito Eduardo.” 
Seu Albertino estava com uma ferida na perna, que segundo ele, não curava. Ele relatou que foi a Cavalcante para consultar, mas que o hospital não tinha os exames para ele fazer para verificar se era diabetes e mandou ele ir para Goiânia. Ele precisou ir a Goiânia, mas quando chegou lá não tinha agendamento nenhum, então ele pagou uma clinica particular para fazer o exame, que não detectou diabetes. Pagou também para fazer exame de rim e pagou os remédios - um antibiótico e a pomada de cicatrização ( $R$ \$ 96) que a médica particular passou. “Tive que ficar sem comprar o café para comprar esses remédios". Seu Albertino falou com revolta, por que ele sabe que teria direito a ter a consulta, aos exames e aos remédios pelo SUS, mas não teve acesso.

Seu Albertino é muito orgulhoso de seu lugar. "A senhora pode vir aqui com sua barraquinha e colocar aqui, que ninguém mexe em nada." Falou de uma série de pessoas que tiveram no Vão de Almas, provavelmente pesquisadores, e disse que todos passaram muito tempo lá e que gostavam muito de lá.

Falou de uma professora "de fora" que foi para lá há cerca de 30 anos e montou aquela escola perto de sua casa. Foi a primeira escola de lá. "Foi aí que as coisas começaram a melhorar".

“Tá miorando mais. Ave Maria se tivesse naquele tempo. Até sopro de saúde o povo aqui agora num é mais doente" depois da titulação. Depois que abriu a estrada, toda muie que tá gestante, quando tá na hora de ganhar menino, alguém liga e o carro vem buscar na hora." Eles ligam da casa de Seu Zezinho por que ele tem uma antena de celular e é a única casa que pega celular. "Deus abençoe que pegue um dinheirinho na mão e eu pagava uma antena para ter um celular."

"Eu tô ouvindo essas notícias que a Dilma tá cortando a aposentadoria. Que tá passando na televisão." "ás vez pode cortar até de umas pessoa que num tem precisão. Num tem gente rica que não precisa aí pegando aposentadoria?” (esclareci que a aposentadoria é um direito).

Seu Albertino é aposentado, e sua renda é de um salário. "Da idade que eu tô, num tô aguentando mais nem trabaiá de roça, que eu tratava minha roça de arroz, milho, mandioca. Mas a senhora tâ vendo essas mandiocas aí? E minha Fui eu que plantei. E pego meu 
dinheirinho de minha aposentadoria eu não gosto de jogar no mato. A senhora tá vendo esse pasto verdinho aí? Eu que paguei o trator e mandei gradear, comprei semente de $\mathrm{R} \$ 180$ o saco e mandei plantar."

Perguntei a ele sobre a construção de sua casa, que é uma das poucas no Vão de Almas construída de alvenaria e telhas.

"Fui eu de meu bolso que eu paguei. Num tem nada de prefeitura. Num tem nada de projeto. Tem uma lei aí de dar moradia. Nada aqui nós nunca recebeu."

Diz que ainda vai pintar sua casa até o dia 15 de julho, quando vai fazer uma sussa para seus amigos do Vão.

Diz que o dinheiro do governo federal vem. "Mas esse Dinheiro que vem de fora se passar pela prefeitura ninguém vê ele, num chega. Aqueles que trabaia lá dentro da maloca, es agrada aqueles que trabaia dentro da maloca e o dinheiro num sai lá de dentro não. Prefeito tem poder num tem? Mas o dinheiro não sai pra fora da maloca. Ele come ele tudo".

Perguntei a ele se há problema de fome. Ele diz que não "a fome que tinha antigamente, essa Deus num deixa entrar mais".

A alimentação vem da roça e do que eles compram na cidade. "Mas a comida que a gente compra na cidade vem tudo envenenado".

Seu Albertino diz que alguns recebem o Bolsa Família e outros não. Ele sabe que é só para quem tem crianças estudando. Uma mulher que estava em sua casa diz que recebia mas o valor do benefício era só de $\mathrm{R} \$ 60$ por que ela só tem um filho na escola. Como ela tem que pagar o transporte de $\mathrm{R} \$ 50$, somente sobre $\mathrm{R} \$ 10$. "Não dá nem para comprar um remédio", diz ela.

A mulher diz que todo mundo leva os filhos para vacinar na cidade. Quando tem campanha, a vacina vai dentro da comunidade. Todas as crianças estão na escola. Ela diz que daqui a pouco não tem mais analfabeto lá dentro. Só os velhos.

Ele diz que todo mundo adora o Vão de Almas por que lá é sossegado. "Só a tranquilidade que tem aqui!’. Ele diz que foi lá em Goiânia e nunca viu tanta tristeza no mundo. 
Ele fica muito feliz quando eu disse que tinha achado bonito lá. Ele então fala dos botos e das arraias no rio, incentivando que eu passeie lá.

“NASCI E CRIEI AQUI E DAQUI EU NAO SAIO”. Ele contou que tentaram construir uma barragem no rio Branco ( como eles chama o Rio das Almas) mas eles não permitiram. Ele diz que um advogado disse que eles iriam ter água na pia. Mas eles não acreditaram que iria ser benéfico para a comunidade. Eles se reuniram e não deixaram. "Nós acredita é em Deus."

“ A gente antigamente quando via uma pessoa igual a senhora e o seu Beto aí, só via os adultos, por que os meninos tudo fugia, de medo [...] foi o povo da SUCAM que amansou nós".

Seu Albertinho mora sozinho pois seus filhos, que são 12 vivos, moram fora na cidade e alguns casados em outras casas no Vão. Mas sua casa vive cheia. Como sua casa é perto da escola, vive cheia de meninos, de mulheres e pessoas amigas.

Ele diz que vive bem demais, pois não paga água, só precisa comprar o fósforo e óleo para acender sua lamparina.

Ele diz que lá só precisa de energia, posto de saúde e água encanada. Fala da importância da água para molhar horta. 


\section{VÃO DE ALMAS- CONVERSA COM DONA PERCÍlIA DOS SANTOS ROSA, MERENDEIRA, 8 FILHOS, SENDO 5 VIVOS E IRENE, 25 ANOS, PROFESSORA DO ENSINO FUNDAMENTAL I DA ESCOLA SANTO ANTÔNIO}

A conversa com as profissionais da escola foi uma boa coincidência. Na verdade, saímos da casa de Seu Zezinho determinados a ir na cada de Dona Dainha, famosa por ser a Rainha do Vão de Almas.

Dona Dainha mora longe. Andamos de carro por cerca de 15 minutos (da casa de Seu Zezinho demorou mais por que tivemos que parar para bater a enxada na estrada para o carro passar, já que tinha chovido muito à noite e uma vala havia se formado na estrada) até a beira do Rio das Almas, onde deixamos o carro para atravessar por meio de uma canoa. De lá andamos cerca de 1 hora até o próximo rio- o Capivara, onde atravessamos a pé. Andamos, bem rápido, mais uns 30 minutos, quando avistamos a escola e começou a chover. Paramos para esconder da chuva e Seu Zezinho resolver perguntar se Dona Dainha estava em casa, já que teríamos que andar mais uns 40 minutos, segundo ele. Daí fomos informados que ela estava em Goiânia. Depois de andar mais de 1h30, e rápido, fiquei meio frustrada por não ter a chance de conhecer a tão falada Dona Dainha.

Mas a viagem não foi perdida. Enquanto esperávamos, Beto disse que eu poderia conversar com Dona Persília, que era a merendeira. Fui então até ela, que estava acompanhada de Irene, que acabei descobrindo na conversa ser professora. Pedi então permissão para conversar com elas sobre a pesquisa. Explique que queria entender como as políticas públicas, se tinham chegado, tinham melhorado a vida deles, e, se não chegado, como afetava sua qualidade de vida.

Dona Percília começa a conversa com certa revolta por que, em suas palavras, "nada chegou, tudo falta: a estrada, luz para todos, transporte, ponte".

A professora Irene interrompe e diz: "Basta falar que a vida aqui é sofrida. Já diz tudo".

Dona Percília concorda: "Muito sofrimento aqui. Quando tá aqui dentro é bom, mas pra sair e até chegar". 
As duas fazem coro ao concordarem que o descaso da prefeitura é grande. O discurso é uníssono " na hora do voto, eles procuram a gente, depois somem" [...] "Eu até falei que quando tivesse uma eleição, ninguém votava.[...] Kalunga só tem valor na hora do voto, depois, votou, acabou", reclama Dona Persília indignada.

Fala sobre a dificuldade enfrentada pelas crianças por causa de uma medida da prefeitura que fechou metade das escolas dentro do Vão de Almas no sentido de juntar as crianças em poucas escolas e colocar transporte escolar. Por causa disso, muita gente perdeu emprego e as crianças precisam andar muito para chegar na escola já que o transporte escolar, na época de chuva, por que o rios e os córregos enchem, não consegue andar nas estradas. O carro do transporte escolar, que é um ônibus 4 por 4, está na prefeitura parado, e as crianças andam em baixo de chuva, atravessam os rios de canoa e levam até 2 horas caminhando para ir estudar.

Dona Persília fala com muita tristeza do isolamento em que eles se encontram: "Nós agradece muito o Jonas ( o dono do caminhão pau de arara que faz o transporte privado até a cidade), por que ele que faz a linha aí, nós paga (caro) mas nós agradece. Por que é o único transporte que tem".

Dona Percília fala que só consegue ir na cidade uma vez por mês por causa do valor do transporte. Ela recebe o BPC por causa de seu filho deficiente. Ela tinha o Bolsa Família, mas foi cortado, e ela não entende por quê. Eu tentei ajudá-la a entender se era por causa da renda do filho que subiu a renda familiar, mas ela diz que não entende, por que muita gente recebe o Bolsa Família e tem aposentadoria ou outras rendas. Tinha muita gente envolta na hora e muitos tinham uma história para contar de gente que precisava e não recebia e de gente que não precisava e recebia. Ninguém entende o valor recebido por família. Houve grande confusão nesse momento por que todos falavam dos valores que eles ouvem falar de famílias que recebem muito, ou de famílias que recebem pouco. Na verdade, ninguém consegue entender as regras do Programa.

A insatisfação quanto à assistência médica em Cavalcante também é grande. Dona Percília diz que quando chegam lá, por volta de 10h, não tem mais ficha. Eles distribuem as fichas de manhã, e eles não chegam a tempo de conseguir. 
"Se tiver necessidade, tem que ir para Campos Belos e pagar médico particular", conforme relatou a Professora Irene.

As mulheres grávidas vão para a cidade quando a data prevista do parto está próxima. Elas ficam nas casas de amigos ou parentes Kalunga que tem casa em Cavalcante.

Três filhos de Dona Percília morreram com poucos meses ou até mesmo dias. Hoje ela diz que não há mais mortalidade infantil, dando o crédito para o fato de que as crianças tomam vacina e as mães fazem o pré-natal. Dona Percília nunca realizou um pré-natal. Ela tem um filho com deficiência mental, mas não mencionou a causa. Fiquei me perguntando se um prénatal poderia ter evitado.

Dona Percília também não mostra satisfação com o trabalho prestado pelo agente comunitário de saúde- ACS, que é Kalunga. Ela diz que ele não pesa as crianças. "Tem uns aí que faz né, mas o que vai lá em casa mesmo, num faz nada". "Eu mesmo num chamo ele pra nada. Ele corre atrás de um carro quando as pessoas precisam, mas ir nas casas mesmo, ele não faz.” A insatisfação de Dona Percília quanto ao trabalho do ACS me deixou intrigada, por que muitos outros tinham falado bem, fiquei na dúvida se ela não tinha uma expectativa grande demais ou desconhecimento quanto ao que ele deveria fazer.

Perguntei à Professora Irene se na opinião dela as crianças tinham maior frequência na escola devido à condicionalidade de educação do Bolsa Família. Ela respondeu que "tem uns que sim e outros que não". Sem entender, pedi que ela esclarecesse, e ela disse que muitos não cumpriam a exigência de frequentar $99 \%$ das aulas. Explique a ela que não era necessário frequentar $99 \%$ e $\operatorname{sim} 75 \%$. Ela ficou meio constrangida e justificou que como não tinha filhos, não entendia nada do Programa, que se tivesse, ela estava mais atenta. Daí ela disse que eles tem "umas faltinhas poucas, mas vem".

A merenda escolar do município estava em falta havia 10 dias. Quando isso ocorre, Dona Persília e Irene dizem que não há muito o que fazer e as crianças ficam com fome, pois somente alguns trazem lanche de casa. A única solução encontrada pela escola é dispensá-los mais cedo. Então, quando isso ocorre, e Dona Persília diz que é normal eles ficarem 2 ou 3 meses no ano sem merenda, eles tem aula somente de $7 \mathrm{~h} 30$ às $9 \mathrm{~h} 30$ ou $10 \mathrm{~h}$. 
Pergunto a ela se o município compra alimentos da comunidade, já que muitos planta. Ela diz que não, que tudo vem comprado da cidade, inclusive abóbora, que tantos Kalunga plantam. Ela diz que às vezes as verduras já chegam lá estragadas e elas tem que jogar quase tudo fora. Por isso, o pouco que sobra, ela mistura no arroz para dar. Não dá para fazer uma sopa ou uma salada para as crianças, por que a verdura é pouca.

Para os meninos da escola estadual, que funciona na parte da parte, na mesma escola, há alimento suficiente sempre. Além disso, segunda ela, a variedade enviada para o lanche da escola estadual é muito maior. "Até carne tem para os meninos do Estado".

A Professora Irene está lecionando na escola por contrato temporário do Estado. Ela tem somente o ensino médio. Ela diz que como tem poucos professores disponíveis, eles aceitam professores somente com ensino médio mesmo. Ela diz que tem tentado entrar na UNB - no Programa Educação do Campo, mas não conseguiu passar ainda.

Irene informou que as crianças começam a ser alfabetizadas no pré 3. Eles já começam com a letra cursiva. Ela diz que não ensinam a letra de forma na escola. Eles tem aula de português e matemática no pré 3 e no primeiro ano. Eles não possuem biblioteca na escola: "às vezes ainda vem. A gente não perde a esperança".

A escola está em reforma. Está sendo construído um refeitório pelo Estado. A escola é do Estado, mas está sendo dividida com o ensino municipal.

As turmas são multiseriadas: primeiro ano junto com pre 3, segundo com terceiro ano, quarto com quinto ano, sexto com sétimo ano.

A professora reclamou que muitos alunos não recebem incentivo em casa para estudar, que os pais não ajudam na tarefa de casa. Ela diz que os pais dizem que "quem tem o direito (ela quis dizer dever) de ensinar é os professores que estão ganhando".

A maioria das crianças que terminam o nono ano na escola dentro do Vão querem sair para poder continuar os estudos. Mas, segundo a Professora Irene, “é difícil demais”. Eles sonham também em fazer faculdade, de acordo com a professora. "Cada um fala uma coisa que quer ser" 
A professora Irene diz que seu sonho sempre foi ser professora. Agora, "com fé em Deus", diz ela, "eu vou fazer faculdade".

Ela informou que muitos professores de lá estão cursando o curso na UNB, inclusive sua mãe e seu irmão. (mais tarde, em outra missão eu conheci sua mãe, uma professora experiente, que sabia falar muito bem e que estava muito orgulhosa de estar se formando no curso)

A Professora Irene diz que não gostaria de sair do território Kalunga. Quando perguntei por que ela gostava de morar lá, a resposta dela foi parecida com a de quase todos que perguntei: "Nasci e criei aqui. Eu gosto de ficar aqui."

Ela mora em uma casa de adobe no Vão, mas quando vai para a cidade ela tem que ficar na casa que sua mãe tem na cidade. Ela diz que quer construir uma casa para ela em Cavalcante. Diz que a maioria das pessoas fazem isso. Tem uma casa na cidade para poder resolver as coisas que precisam: ir ao médico, ir ao Banco, ...

Irene ainda não tem filhos por que quer fazer sua faculdade primeiro. 


\section{MISSÃO A CAVALCANTE, GO - 19 E 20 DE MARÇO.}

\section{CAVALCANTE, GO, 19 DE MARÇO DE 2015 \\ REUNIÃO COM VILMAR, PRESIDENTE DA ASSOCIAÇÃO KALUNGA,}

A terceira viagem ao Vão de Almas ocorreu juntamente com o coordenador do Programa Cisternas do MDS. Eu, não conseguindo ficar isenta totalmente, solicitei ao coordenador que fosse comigo ao Vão de Almas para ver a possibilidade de instalar as cisternas de placa para o consumo e as cisternas calçadão para a produção agrícola e para o alimento de pequenos animais.

Mais uma vez chovia muito. Marcamos uma reunião com o Presidente da Associação Kalunga, com o apoio de Beto, em Cavalcante, antes de ir ao Vão de Almas.

A intenção da reunião com o Presidente da Associação Quilombo Kalunga era verificar que comunidades tem maior necessidade de captação de água e a capacidade institucional e de execução da associação. O Programa funciona por meio de contratação de um entidade, de preferência uma ONG que tenha experiência com o lugar, para a construção das cisternas.

Segundo Vilmar, as principais áreas com necessidade de receber cisternas são o Vão do Moleque, Vão de Almas, Choco e Malhadinha. No Vão do Moleque 50 casas receberam a cisterna de plástico do Ministério da Integração. Os critérios utilizados para a seleção foram a necessidade de água e, principalmente, as casas que já tem telhado de cerâmica, por terem sido beneficiadas pelo Programa de Habitação, para a instalação das calhas.

No entanto, a maior parte das casas no Vão do Moleque são de adobe com telhado de palha. Assim, os domicílios mais vulneráveis não foram beneficiados pelo Programa do MI. São casas no meio do cerrado, longe das estradas e sem acesso à água.

Não há previsão de chegar outras cisternas do MI no Vão do Moleque ou no Vão de Almas, onde praticamente todas as casas possuem telhado de palha, com exceção de cerca de 10 
casas, cujos proprietários, por iniciativa própria, construíram casa de alvenaria com telhas Eternit.

Alguns moradores já se dispuseram a construir um varal com telhas para captar a água de chuva a fim de se beneficiar com a cisterna.

Foram apresentados os principais pontos do Programa Cisternas: tipos de cisternas, modo de execução por meio de uma instituição guarda-chuva, que poderá contratar as metas locais, repasse de recurso, prestação de contas por resultado.

A cisterna calçadão impressionou bastante o Presidente da Associação, uma vez que a população Kalunga precisa de água também para plantar. Outra grande necessidade é a Cisterna Nas Escolas, pois as crianças bebem água que os funcionários da escola buscam com balde nos rios.

A Associação Quilombo Kalunga- AQK, fundada em 1999, tem experiência com alguns projetos. Foi citado um projeto com a Petrobras no valor de $\mathrm{R} \$ 1,3$ milhão, mas que não foi muito bem sucedido na prestação de contas, segundo relatos de moradores do Vão de Almas. Além disso, a AQK foi contratada pela Caixa para execução da construção das casas por meio de parceria com a FUBRA-UNB para o programa de habitação quilombola. Agora o PNHR também está em contato com a associação para uma nova etapa de construção.

A ${ }^{37}$ Associação Quilombo Kalunga - AQK é a associação mãe, abarcando as associações Kalunga de cada município (Cavalcante, Monte Alegre e Teresina). A participação popular tem sido incentivada para fortalecer o coletivo. 790 pessoas votaram na eleição para presidente da associação. Sua sede, em Cavalcante, funciona meio período para atendimento à população.

${ }^{37}$ quilombokalunga.org.br 
Receber recursos é uma grande responsabilidade para a Associação, mas com uma parceria com uma entidade guarda-chuva, que possa auxiliar, ensinar e capacitar a associação, a Associação acredita ser possível executar.

O Presidente relatou experiência e conhecimento com a ${ }^{38}$ ASSOCIAÇAO OMBRO AMIGO, sediada em Goiânia, que está trabalhando na construção de casas na cidade. É preciso mapear outras entidades que tenham experiência com políticas públicas e que conhecem o território Kalunga, preferencialmente.

Foi informado que as entidades locais precisam se credenciar no MDS para participar do Edital. Se o edital for lançado até o meio do ano, é possível fazer as primeiras entregas ainda em 2015.

Informou-se também que a proposta de cisternas deve vir da comunidade. Assim, o MDS poderia discutir em conjunto com a associação o melhor modelo para implantação no Quilombo Kalunga, e este poderia ser replicado em outras comunidades quilombolas.

Vilmar se dispôs a ir até Brasília para reunião com a equipe do Programa Cisternas para discussão do projeto. Outra possibilidade de encontro foi durante a reunião da Associação nos dias 11 e 12 de abril, quando estarão reunidos os membros do Comitê de Pesquisa da Associação. Como a comunidade já estará reunida, seria interessante tirar um tempo para a equipe do MDS fazer uma apresentação sobre o Programa. A reunião é de grande importância para que os Kalunga tenham informação para poder fazer sua demanda.

Outras organizações citadas por Vilmar (não sei se entendi bem a pronuncia de algumas) que poderiam ser consultadas para parceria com AQK:

${ }^{39}$ ECOTERRA; ECOIDEIA (selecionada no Edital de ATER do MDA); IASGO (já fez trabalho com Kalunga, ficou em segundo lugar no edital do MDA); Hipotecampo; Funil; KC ;

\footnotetext{
${ }^{38}$ associacaoombroamigo.org

${ }^{39}$ www.ecoterra-bio.com.br
} 
${ }^{40}$ IIEB- Instituto Internacional de Educação do Brasil (projeto chapada dos veadeiros: está oferendo curso de gestão na associação e formação de lideranças, além de projetos de conservação e uso sustentável da biodiversidade)

\section{CAVALCANTE, GO, 20 DE MARÇO DE 2015}

\section{CONVERSA COM DRA. MARTA DAMASCO, MÉDICA DO PROGRAMA MAIS MÉDICOS,}

Dra. Marta relatou seu conhecimento empírico sobre a saúde dos Kalunga no município de Cavalcante. Como não há prontuário eletrônico, as informações estão sistematizadas no DATASUAS por internação e mortalidade somente. O prontuário eletrônico deve ser instalado na semana seguinte. Ela se propôs a verificar uma forma de fazer uma marcação "Kalunga" para ser possível obter uma tabulação dos dados mais específica dessa população.

Em 18 meses de prática médica em posto de saúde no município de Cavalcante, Dra. Marta observou que entre os meses de setembro a novembro, após o final da seca, as queixas mais frequentes são diarreia, constipação, dor no estômago e outras relacionadas a doenças de veiculação hídrica. Verificou também alguns resultados de exames de fezes com indicação de giardíase. Os sintomas estão presentes em crianças e adultos.

Observei que muitas crianças e mulheres apresentam aumento do volume da barriga e perguntei à Dra. se poderia ser por causa de vermes. Dra. Marta explicou que podem ser verminoses e carências nutricionais, como carências de vitamina B e de ferro. Após o período da seca, são diagnosticadas pessoas com anemia por carência, devido à alimentação pobre em nutrientes. Na seca, eles não conseguem plantar a abóbora, o jiló, o maxixe, e outros legumes que são de costume alimentar dos Kalunga. Na seca, a paisagem do Vão do Moleque e o Vão de Almas é de areia e árvores secas. Assim, a alimentação deles é somente do que eles conseguem comprar com o Bolsa Família ou a aposentadoria: arroz, feijão, café, sal, açúcar e macarrão praticamente. Na época da chuva, eles plantam arroz, feijão, mandioca, milho, alguns legumes, e criam galinhas.

40 iieb.or.br 
Outra queixa frequente causada pela falta de água é a cervicalgia, presente principalmente nas mulheres que andam $5 \mathrm{~km}$ a $6 \mathrm{~km}$ para pegar água e trazê-la na cabeça.

Algumas já mostraram o resultado da ressonância magnética, feita pelo SUS em Goiânia ou em clínicas privadas e o diagnóstico foi comprovado: desgaste das vértebras cervicais, deslizamento de vértebras, hérnia de disco, e outros. Elas são solicitadas a pararem de carregar água, porém isso é difícil, pois muitas não tem quem o faça para elas.

Isso acontece em toda a área rural do município, não só no território Kalunga. $\mathrm{O}$ sertão de Cavalcante é grande e a maior parte de sua população sofre com a falta de água, tendo que andar bastante para pegar água, pois os riachos e ribeirões secam.

A qualidade da água é outro fator preocupante. Os Kalunga bebem a água dos rios e riachos sem tratamento. Mesmo no Engenho, onde a água vem encanada da serra, a qualidade é comprometida com a contaminação pela terra, pois as mangueiras, por não estarem bem enterradas, quebram/furam ao serem pisoteadas por pessoas, gado, cavalos e carros. Assim, fezes de animais fazem solução de continuidade com a água. Como a água não é tratada para beber ou cozinhar, os Kalunga em geral sofrem com verminoses e diarreias. 